
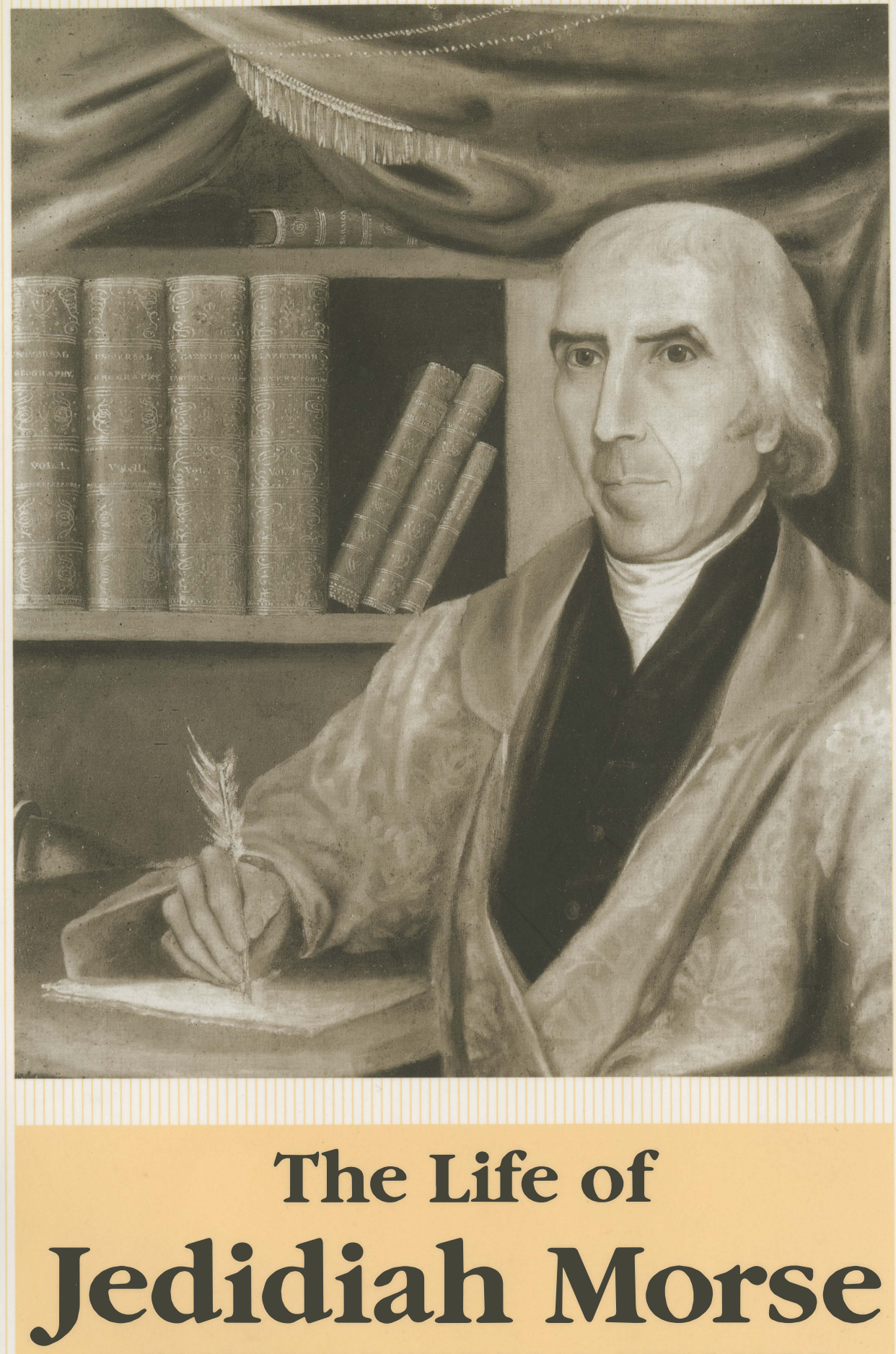

A STATION OF PECULIAR EXPOSURE

\title{
..............
}

Richard J. Moss 
"Richard Moss locates Jedidiah Morse as a man torn between a republican past and a liberal future, a paradigm certainly familiar to scholars in this field. But Moss also seeks to understand Morse as a human actor through the provocative and perhaps controversial application of psychological evidence and interpretation."-John Andrew, Franklin \& Marshall College

Jedidiah Morse-clergyman, geographer, and father of the painter and inventor Samuel Morse-was a significant figure in postRevolutionary New England. Through his popular geography texts, he described the new nation to Americans. As a prominent Congregationalist minister, he involved himself deeply in the heated religious controversies of his day. As a polemicist, he voiced the anxieties Americans felt about such turbulent events as the French Revolution and the political and religious changes their own country was undergoing.

As Richard Moss reveals in this compelling biography, Morse was caught in a personal dilemma that reflected the larger tensions within his society. On the one hand, he played the role of self-sacrificing minister-a role drawn from the expectations of his father and the Connecticut traditions in which he was reared. In this capacity, he adopted the language of Christian Republicanism and sought to defend the virtues of communitarian village life, austerity, and deference to the Federalist leadership. On the other hand, Morse recognized the opportunities offered by the emerging liberal, capitalist culture. As an author and speculator, he amassed a small fortune and became enmeshed in a web of financial gambles that ultimately ruined him.

Drawing on psychological theory, Moss argues that, far from remaining separate, the two sides of Jedidiah Morse were dependent upon each other. Because Morse lacked a sense of wholeness, Moss contends, he 
The Life of Jedidiah Morse 


\section{The Life of Jedidiah Morse A STATION OF PECULIAR EXPOSURE}

Richard J. Moss

The University of Tennessee Press $\bullet$ Knoxville 
Copyright () 1995 by The University of Tennessee Press / Knoxville. All Rights Reserved. Manufactured in the United States of America. First Edition.

The paper in this book meets the minimum requirements of the American National Standard for Permanence of Paper for Printed Library Materials. (2) The binding materials have been chosen for strength and durability.

\section{LIBRARY OF CONGRESS CATALOGING IN PUBLICATION DATA}

Moss, Richard J.

The life of Jedidiah Morse: a station of peculiar exposure / Richard J. Moss1 st ed.

p. $\quad \mathrm{cm}$.

Includes bibliographical references and index.

ISBN 0-87049-868-1 (cloth: alk. paper)

1. Morse, Jedidiah, 1761-1826.

2. Congregational churches-Massachusetts-Clergy-Biography.

I. Title.

BX7260.M57M57

1995

92-28143

285.8'32'092-dc20

CIP

[B] 


\section{Contents}

Acknowledgments

Introduction

1. Woodstock and Deacon Morse

vii

ix

2. To Yale and the World 13

3. A Place in the World: Settlement 35

4. A Period of Singular Revolutions 54

5. The Two-Layered Life 81

6. Family 116

7. The End 131

Epilogue 143

Notes 151

Bibliography 166

Index 173

\section{Illustrations}

1. Samuel F. B. Morse, The Morse Family Group, c. 1809

2. Samuel F. B. Morse, The Reverend Jedidiab Morse, 1809

3. Samuel F. B. Morse, The Reverend Jedidiab Morse, 1816-17

4. Samuel F. B. Morse, The Reverend Jedidiab Morse, 1823

5. Samuel F. B. Morse, The House of Representatives, 1822-23 



\section{Acknowledgments}

A number of people have made the writing of this book easier and more enjoyable. I owe a huge debt to countless librarians and archivists who cheerfully provided the manuscripts and arcane pamphlets and sermons on which this book is based. The talented staffs of the Manuscript and Archives sections of the Yale University Library and the New York Public Library deserve special mention.

I have benefited from the support and advice of close friends and distant scholars. Pearl Rose, Robert Weisbrot, Greg Pfitzer, James Roberti, and Patricia Walls have all, in different ways, helped me finish this book. A number of my students at Colby College, Waterville, Maine, provided invaluable aid. Laura Carlson was especially important. To a great degree, this volume was written in scholarly isolation. At crucial moments, however, I received support and critical readings from Harry S. Stout and William K. Breitenbach for which I am deeply grateful.

Colby College has provided much-needed support over the years. The Colby College Library staff has been unfailingly patient and helpful. Patricia Kick and Grace Von Tobel have translated my low-tech, pen-and-paper manuscripts into wonders of the word processor's art.

By design, my wife Jane and son David know little about Jedidiah Morse. Their contribution to this book has been the hardest to define, yet the most important. Finally, I should like this volume to serve as a small payment on the considerable debt I owe to Douglas T. Miller and the late Russel B. Nye of Michigan State University. 



\section{Introduction}

From 1789 to 1819 , the Reverend Jedidiah Morse was a prominent figure on the streets of Charlestown, Massachusetts. Charlestown citizens often encountered this tall, slender man making his way through the streets on some errand. His dress singled him out as a gentleman of the old school. His powdered hair, knee-breeches, silver-buckled shoes with a high shine, and the odd gloves with the fingers cut off contrasted sharply with the dress of the dayhe must have seemed like an apparition, a time traveler from an earlier age. One day, early in the nineteenth century, Lucy Osgood, a teenager in his parish, approached this formidable figure and revealed her religious troubles. She was falling away from the orthodox faith that Morse preached and was attracted by the liberal doctrines popular in the Boston area. Lucy recalled that Morse's response was unequivocal; he assured Lucy that "the first step of deviation from the old orthodox faith was the beginning of a descent down an inclined plane towards the bottomless pit." ${ }^{1}$ This episode captured the essence of Morse's public persona; he was a tireless defender of the ancient arrangements, religious, political, and social, that postrevolutionary Americans had inherited from the New England past.

This rigid, unlovable man, who was willing to terrify a young girl with visions of hell, was an important figure in American life between the Revolution and 1825. Americans by the thousands learned about their new nation from his geographies, which, for thirty years, were dominant in the nation's schools and a staple on family bookshelves. His name was so inextricably linked to geography that his son, Samuel, while at Yale, was known as "Geography" Morse. Americans also read his printed sermons with their warnings of subversive conspiracies against the American way and their deeply ingrained conservative message, and many were convinced. He was a pioneer journalist; he helped found and nurtured the Panoplist, one of the most important conservative religious periodicals of the era. Profoundly shaken by what he saw as threatening innovation, Morse helped establish educational institutions designed to inculcate what he called the faith and ideas of the New England fathers. Frightened by the religious ferment of his age, he sought to reestablish the religious homogeneity he believed characterized the New England past. Ironically, in the end, his attempts to put out the fires of religious conflict only made them roar on all the hotter.

His distinctive vision, a religious, conservative republicanism, had a discernible impact on the course of American life. Morse must be placed 
in a long-standing ideological tradition still influential in American life. The religious right, or evangelical conservatives, of the 1970s and 1980s share a great deal with Jedidiah Morse. They see in secular humanists, socialists, Washington bureaucrats, and liberals, conspirators against the virtues they believe existed in a purer and simpler American past.

Simply put, Jedidiah Morse is an important example of an American type. It is easy to forget that such types ever existed. In a nation that has come to celebrate change and progress, those like Morse who defended the past and feared change seem very much like history's losers. They exist in our memory, unfortunately, only as representatives of that which was overtaken and rejected as America marched inexorably toward the Promised Land. It is more accurate to see Jedidiah Morse as someone who, more than most, embodied the conflicting impulses present in American life; impulses that were violently at odds between 1780 and $1820{ }^{2}$

Exactly what were these conflicting impulses? The years between the Revolution and 1820 are the subject of a great deal of debate, and in this debate, the shorthand abstractions "republicanism" and "liberalism" have played a prominent part. Certainly many Americans reflected the republicanism of the times by emphasizing the need for virtue, obedience, selfsacrifice, and simplicity. Very much a secularized version of Puritanism, these republican values featured a generalized anxiety about the nature of the people. Many Americans, like Morse, made frequent pleas for their fellow citizens to reject luxury, individualism, and self-seeking. They also called for deference and obedience to an elite; these calls were tinged by patriarchal and familial language. Their ideal republic was composed of wise, benevolent fathers and obedient children. The Revolution, in their view, should not erode the central role of the family metaphor in structuring society and political life. Morse articulated a Christian-New England version of this republicanism; he put special emphasis on the necessity of maintaining the particular values of New England culture and New England religion. ${ }^{3}$

In his sermons and geographies, Morse became an important spokesman for a widely shared set of attitudes and concerns that has been called a "dialect of republicanism." This dialect was common among New England clerics and others with deep connections to New England's past. Although Morse's republicanism ranged over a variety of issues, he put special emphasis on the need for piety and effective government. Repeatedly, he insisted that republics, in order to survive, needed more than simple virtue; the truly republican citizen must be a true Christian. For Morse, there was no such thing as private sin. He assumed that private impieties were ultimately ruinous to the body politic; individual behavior, especially selfishness, eventually harmed the community. To control behavior Morse 
called for a powerful government and a citizenry ready to obey such a government. He spoke easily of "rulers" and of people deferential and grateful to a natural aristocracy that controlled them. New England ministers like Morse expressed this version of republicanism with voices that betrayed a "besetting anxiety." They, more so than other Americans, possessed barely repressed doubts about the republican experiment and joined in the postrevolutionary public debate fully aware that the libertarian direction of opinion in the early republic fundamentally threatened the established clergy to which many of them belonged. Morse, like so many of his fellow Congregational ministers, was a very anxious republican. ${ }^{4}$

Yet while he was preaching this version of republicanism, Morse was acting very much like a new American liberal. Although the Revolution gave strength to republican demands for self-sacrifice and community-oriented virtue, it also unleashed other powerful notions, collectively known as liberalism. Most importantly, liberalism offered a transformed meaning of the word virtue. Instead of sacrificing private needs to community well-being, liberalism called for the individual to pursue personal fame and wealth with single-minded devotion. Deeply entwined with the early stages of a capitalist economy, liberalism made the free market and its manipulation central values. Beneath the rise of liberalism lay a profound social revolution. In the last half of the eighteenth century, the conservative communalism that was the cultural basis of republicanism wore away and evaporated. Tight, conservative communities that had kept their sons and daughters in a close embrace for two, three, or even four generations lost their grip. Younger sons could no longer stay home near their father and his control; there was simply no land or opportunity in towns like Woodstock, Connecticut, where Jedidiah Morse was born. Economics and demographics pushed increasing numbers of young men and women to the frontiers, both rural and urban. After the Revolution, towns like Charlestown were very much animated by a frontier spirit. In such towns the new spirit of liberalism coexisted uneasily with the more conservative ideas inherited from a Puritan past. Cash, commerce, and cosmopolitanism wore away the encrusted traditions of the seventeenth and eighteenth centuries; liberal, democratic America was emerging. ${ }^{5}$

Two notions were particularly corrosive: equality and religious pluralism. All hierarchical and patriarchal institutions were challenged by the revolutionary rallying cry-equality. The notions of natural authority and distinctions were challenged as wider opportunities to become wealthy transformed the urban scene into a scramble for material gain. Individuals grew impatient with the republican calls to accept their humble stations in life; the emphasis on equality bred individualism, disorder, and a suspicion of established authority. The Protestant minister, especially in the established denominations, suffered particularly. Morse, who occupied one of the oldest 
Congregational pulpits in New England, never was accorded the deference his predecessors received. The idea that each town would call to its church a minister to act as its single moral and spiritual guardian expired after the Revolution, having been attacked, on the one hand, by rationalists who emphasized free thought and the individual's right to construct his own religious views and on the other hand by a growing array of dissenting sects demanding liberation from the intellectual, spiritual, and financial constraints imposed by a tax-supported established church. Especially in the Boston area, religious toleration and pluralism grew rapidly. For Morse, who saw religion as the source of morality, and for whom morality was the basis of the state, the proliferation of denominations and the growth of rational religion and unbelief were deeply distressing. Finally, religious liberalism challenged the gloomy doctrines of Calvinism: innate depravity, predestination, and man's inability to achieve grace through simple moral behavior. Morse, in what was essentially a tactical retreat, defended these doctrines, but as he did so, he also embraced the generalized evangelical Christianity that animated the religious revival after 1800 . He was capable of setting aside his Calvinist predilections long enough to participate fully in organizations that sprang up to ensure a moral population. He could and did set aside doctrinal issues if the aim was the moral control of the masses or unity among evangelical Christians. ${ }^{6}$

Liberalism and republicanism are only abstractions that reflect a reallife dilemma. The nation, for perhaps four decades after the Revolution, struggled to establish its identity. Jedidiah Morse was a full participant in this struggle. The essential task of establishing a stable and undivided sense of self was extremely difficult between 1780 and 1820 . The culture provided no clear, well-worn tracks on which to travel; instead, men like Morse received contradictory republican and liberal messages. The result was identity diffusion. A strong ego possesses a sense of its own wholeness and essential goodness; it has an ability to experience change with a sense of trust, hopefulness, and mature flexibility. Morse was denied this wholeness and "basic trust." He experienced change suspiciously and often uttered apocalyptic warnings about the future. ${ }^{7}$

Uprooted from the town of his birth and pushed into a confused and divided culture, Morse developed an ideal identity that corresponded roughly to republican values. His father was the living embodiment of these values, and Jedidiah Morse felt, for most of his life, patriarchal pressure to live a republican life. At the same time, Morse, responding to a changing environment, saw new economic opportunities and took them. Another Morse evolved beneath the republican, self-sacrificing, and nonacquisitive public identity. He found in authorship a way to wealth and a sense of personal worth. It took him away from his role as a parish minister and caused 
him to develop, in competition with his ideal identity, a feared identity (one he could not acknowledge) as an entrepreneur, speculator, and lover of money. Morse was never able to resolve the conflict between his ideal and feared identities, although his father and his congregation insistently reminded him of the division in his sense of self, of his communal duty as a minister to serve the great cause of Christianity with single-minded devotion. For more than thirty years Morse walked a tightrope between a socially affirmed identity as a dedicated clergyman and a controversial identity as an acquisitive man who neglected his flock and søught fame on a larger stage. ${ }^{8}$

Fully understanding Morse's identity conflict helps us understand the important events in his life. We must understand that his confusion was not pathological; he was not in any sense mentally ill. Although the two components of his identity were in many ways opposed, they worked in an odd sort of harmony. Morse's public role as minister and guardian of public virtue offered him the rituals and the platforms to deal with the stress of a double identity. His jeremiads against the decline in public and private virtue and his dramatic proclamations that vast and insidious conspiracies sought to subvert the American Way and True Religion were largely successful attempts to absolve himself of the guilt and anxiety rooted in his own sense of having a hidden identity. There was a reciprocal relationship between his feared and ideal identities; as his feared identity became more public, the need to act according to the dictates of his ideal identity increased. Sermons, geographies, and journalistic pieces, all of which were new-style jeremiads, were his way of purifying his own identity, of "proving" his faithfulness to the values of New England's past.'

Jedidiah Morse fought a long battle for wholeness. He saw that he had lived in "a period of singular revolutions" that disordered the regular, the traditional, and the given. Religious, political, and economic divisions "generated continued Angry Contention, affecting . . . all the social relations of life. In such a period it was my lot to fulfill the course of my Ministry in a station ... of peculiar exposure." A demographic revolution forced him out of the rural village of his birth; he was an early participant in the capitalist revolution; he witnessed the world in which he lived turn against the religious temperament he inherited from his dominating father; and finally, he felt the tremors as America and Europe experienced a revolutionary age. This confrontation with sweeping change in all areas of life flowed together with Morse's fragmented personal experience and made him willing to accept the delusion of wholeness created by his constant promulgation of conspiracy theories. Beginning in the late 1790s, Morse came to comprehend his world as structured by a simple conflict between conspirators of several kinds and virtuous, unwary Americans. 
The central tendency in his thought after 1795 was to construct a single portrait, one all-consuming ideology, that simply explained all of history and created one unalloyed and evil enemy to be dealt with by an equally unalloyed hand of justice. By speaking and writing this way, Morse steadily diverted his personal anxieties and his own sense of sin onto an assortment of self-created enemies. ${ }^{10}$

Countless Americans, between 1780 and 1820, found more flexible, less militant ways of responding to the era. Morse's response to the erahis identity confusion, his conspiratorial temperament, his allegiance to an idealized New England-was the product of a conjunction of factors. Republican and liberal values settled on him and divided him because of the nature of his social and personal experience. He would not have developed as he did if it were not for the unique personality of his father, the equally unique influence of Woodstock, Connecticut, the nature of postrevolutionary Charlestown, the declining status of the established clergy, and the impact of Yale. All of these realities, and more, combined to make Morse what he was. Yet I would like to suggest that there was a final and perhaps determinative factor. Morse was deeply imbued with a Christian language that shaped his life as surely as did the environment of Charlestown or Woodstock. During moments of extreme pressure, when his dual identity was most clearly exposed, he turned to the Christian concept of an absolute divine Providence and the notion that history was understandable as a struggle between good and evil, God and the Devil. These ideas and the language to express them (the Word) were crucial in allowing Jedidiah Morse to collapse the bewildering complexities of his time into simple pictures. Pictures that allowed him to live and work; pictures that comforted him and many other Americans. 


\section{1. \\ Woodstock and Deacon Morse}

When does a life begin? The common sense answer is that existence begins with birth, but that answer runs counter to some fundamental realities. Everyone arrives in this world with a history and leaves having set off reverberations that last long after the last breath. Jedidiah Morse's life was inevitably bound up in the history of his family and in the town of Woodstock, Connecticut. His life is not fully comprehensible until we have some understanding of that family and that town. Jedidiah Morse grew up in Woodstock at a time when the town was becoming increasingly contentious and divided. His father, however, seemed immune to these changes; he was the virtual personification of a village patriarch. Having established his economic independence on the land by virtue of hard work, Jedidiah Morse, Sr., toiled endlessly for his community. He represented the republican ideal of self-sacrifice to the commonweal; his life became meaningful only in the context of community. He belonged, in the truest sense of the word, to the town and the church. As a model for life, he was, as Jedidiah Morse, Jr., found out, rapidly becoming an anachronism.

In 1761, when Jedidiah Morse was born, the town of Woodstock was approximately seventy-five years old. It was the product of the first tentative steps westward made by citizens of Roxbury, Massachusetts. Under the pressure of a rapidly growing population, Roxbury purchased the land that would become Woodstock from Captain John Fitch in 1686. Quickly, thirty families announced their intentions to become "goers." A great portion of the purchased land, however, remained in the hands of "stayers," Roxbury citizens who speculated that land values would rise in what was then called New Roxbury. No Morse was among the original settlers, but Jedidiah's mother could trace her family back to Jonathan Peake, a member of the first group of settlers. The Morse family arrived soon after; Peter Morse, Jedidiah's great-grandfather, received a home lot in the second division of land in $1694 .^{1}$

The early history of Woodstock was troubled. The town was constantly threatened by hostile Indians and a chronic shortage of funds. Citizens of Roxbury had promised those who had settled the town a bounty in cash, but it was not forthcoming. Furthermore, they did not know exactly where they were. They believed that they had built their village in Massachusetts. They had miscalculated and were really in Connecticut. This was crucial for several reasons. Massachusetts law, notably the Cambridge Plat- 
form, called for independent congregational church organization. After Connecticut adopted the Saybrook Platform, which deprived the congregation of some of its independence, the exact location of Woodstock became a matter of religious and political, as well as geographical, interest. Woodstock, along with Suffield, Enfield, and Somers, were constantly disrupted by the inability to settle a most basic issue: were they in Connecticut or Massachusetts? ${ }^{2}$

Beginning in 1690, the town and its first minister, Josiah Dwight, began a long-running conflict. Dwight complained about the smallness of his salary and the inability of the town to pay him even this small sum promptly. In 1725 , after years of acrimony, the town meeting voted overwhelming to dismiss Dwight, but he did not leave town easily. He stayed on until 1735, when he accepted a call from a church in Dedham, and took the Woodstock church covenant and early records with him. ${ }^{3}$

Throughout the first three-quarters of the eighteenth century, Woodstock was disturbed by religious conflict. As the town expanded, settlers to the west demanded the right to establish their own church. After years of debate, the General Assembly of Connecticut finally had to impose a solution from the outside. The assembly declared West Woodstock a separate entity and allowed it to establish a church. The Great Awakening also disrupted Woodstock, manifesting itself in a number of challenges to established churches. In 1741, Eleazer Wheelock, one of the most effective Baptist promoters of the revival, toured the area. In an attempt to curb such itinerants, Connecticut, in 1742 , passed a law making it illegal for such ministers to preach without the permission of the settled minister. Elisha Paine, from Canterbury, Connecticut, sought to challenge this law when he attempted to hold a meeting and to preach in Woodstock without permission. The event took place in the home of John Morse, Jedidiah Morse's grandfather. Jedidiah, Sr., was seventeen at the time and witnessed the event. It is interesting to note that Jedidiah Morse, Jr., who became a major figure in the Congregational establishment, had a grandfather who was apparently decidedly anti-establishment. ${ }^{4}$

Woodstock and the surrounding towns regularly experienced outbreaks of revival and separatist spirit. In nearby Scotland Parish, the congregation turned against the settled minister, Ebenezer Devotion, finding him cold, lifeless, and without "the voice of Canaan" in his preaching. The church split in 1746. Elizabeth Cutler, a member of one of Woodstock's most prominent families, led a small group out of the First Church of Woodstock. They joined with a Baptist church in Leicester in 1749.5

The most notable event in the religious history of Woodstock before the Revolution was the long, bitter conflict between a group within the First Church and their minister, Abel Stiles. The conflict divided Woodstock into two bitter factions and apparently had a number of elements. Stiles's 
personality was overbearing and his opponents charged him with neglecting his religious duties to care for his own financial interests. The north part of town supported Stiles, the south spawned rebels. The lingering dispute over which form of church organization to follow-the Cambridge or the Saybrook Platform-no doubt also played a role.

The conflict dragged on throughout the 1750s. At one point, in 1760, the two sides, men and women alike, staged a pitched pushing-and-pulling match for physical control of the meetinghouse. The General Assembly, appalled by such discord, stepped in and resolved the matter. They created two religious societies in Woodstock; the southern society took possession of the meetinghouse, and the northern group received one hundred pounds in compensation and the services of the Reverend Stiles. Both groups were allowed to use the name First Church of Woodstock. This was a significant event in the history of the Morse family; John Morse, who had opened his house to Elisha Paine, was a stalwart in the anti-Stiles party and a pillar in the new southern church. His son, Jedidiah, Sr., would serve this same church from 1763 until his death in 1819. This church, born of rebellion against the established minister, came into being two years after the birth of Jedidiah, Jr., in $1761 .^{6}$

Thus, a profound conflict between professed ideals and actual behavior characterized the world that welcomed Jedidiah Morse to the planet. New Englanders, for more than a century, had believed that towns should peaceably submit to the moral and spiritual guidance of a trained clergy. The overwhelming majority of ministers in New England in the eighteenth century served only one church during their lifetimes. This was not the case in Woodstock. Yet as soon as the assembly created two societies, Woodstock began the process of creating peace and harmony once again. The record indicates that the two societies existed peaceably, side by side. $^{7}$

Jedidiah Morse's years in Woodstock (1761-79), however, were not placid by any means. For one thing, the town was growing, and this growth was forcing the sons and daughters of Woodstock to seek opportunity elsewhere. As early as 1761, groups were leaving Woodstock for Vermont, New York, and New Hampshire. The ratio between families and available land dropped steadily between 1680 and 1790. In 1680, there were 486 acres per family in Connecticut; by 1750 this figure had dropped to 166 , by 1790 it was 91 . This economic reality profoundly influenced the Morse family. The elder Jedidiah wanted to keep his sons, Jonathan, Calvin, and Jedidiah, near him, but it was not possible. Calvin was given cash, and he moved to Vermont; Jedidiah received a college education; and Jonathan, the eldest, was kept in Woodstock to be the inheritor of the family farm. ${ }^{8}$ 
Religious differences also continued to upset the calm surface of life in Woodstock. In 1763, a Baptist minister converted young Biel Ledoyt, one of West Woodstock's leading libertines. Ledoyt began to convert others, and a full-scale revival ensued. Following time-honored tradition, the minister in West Woodstock, the Reverend Stephen Williams, was labeled cold and lifeless. In 1764, the Woodstock Baptists formed a church and, in 1768, ordained Ledoyt as their minister. In a letter to Isaac Backus, Ledoyt recalled that, during the revival, "our groves range with the bitter outcries of distressed youth."

This Baptist uprising was serious and sustained. Ezra Stiles estimated that Ledoyt had taken very nearly a third of the parish away from the Reverend Williams and the established church. The town responded by assaulting Ledoyt and by denying that a true church existed among the Baptists. When the Baptists refused to pay their church taxes, the town forcibly collected them. Again the colony authorities stepped in and granted the Baptists separate status. However, hostility lingered on; there is evidence that during the Revolution the Baptists of Woodstock were not overwhelmingly supportive of the rebellion because they had not yet been granted religious liberty by the local authorities. ${ }^{10}$

The establishment of a Baptist church disrupted the Morse family as well as the town. Deacon Morse's younger brother, John, joined with the Baptists and became a deacon himself some time in the 1770s. No records exist for the Baptist church, but in the records of the three Woodstock Congregational churches John Morse's name appeared countless times attesting to certificates presented by people who were Baptists in good standing and were seeking an exemption from taxes to pay the salary of the established minister. John Morse, Jr., was in several other ways different from his older brother. His grandson recalled that he often rebuked his absent sons for writing home too often, a sentiment alien to brother Jedidiah. John insisted they save the postage and give it to the church. John also possessed different political views. His older brother was a lifelong Federalist, but John became a Democrat. As was the case in so many other towns, religious views and political affiliation were connected; John's grandson recalled that "every Baptist in town was a Democrat, all the Congregationalists were Federalists." ${ }^{11}$

While Woodstock was being transformed by demographic shifts and religious change, young Jedidiah may well have been comforted by peace and stability in his family's church. In 1763, the southern church called the Reverend Abiel Leonard to its pulpit, and he proved an excellent choice. A year later Jedidiah Morse, Sr., was elected deacon (in town histories he is usually referred to as Deacon Morse). The church followed the Cambridge Platform and "the Congregational Way." Like all such churches it sought to enforce moral discipline. Young Jedidiah may have heard public confessions 
of sins that were given before the congregation. Between 1764 and 1768 there were ten such confessions-nine for fornication and one for neglect of the church. ${ }^{12}$

The Reverend Abiel Leonard stood at the helm of this church from 1763 to 1777 . Born in 1740, he was the son of a minister, the Reverend Nathaniel Leonard, and his wife, Priscilla Rogers. After receiving his master's degree from Harvard, he received a call to the pulpit in Scituate, but he decided to decline the offer. On his way to Scituate to refuse the call personally, "he was Seized with Distraction, Sometimes Dumb and inattentive, sometimes Raving." Leonard recovered sufficiently from this puzzling episode to accept the call from the church in Woodstock. ${ }^{13}$

Leonard's theology was apparently devoid of the gloom and pessimism that characterized much Calvinist thought. He believed that God was "perfectly benevolent" and that this aspect of God's being had been "universally acknowledged in all ages." He believed the Church of Christ was composed of many churches, some pure and some corrupt. Leonard rejected the Saybrook Platform, but he valued peace and he was central in creating a better relationship with Stiles and the other First Church in Woodstock.

Leonard's family life was marked by sadness. His first wife, Dorothy Huntington, whom he married in 1764, died after only fifteen months of marriage, leaving an infant daughter. Less than a year later, he married Mary Greene, daughter of Thomas Greene, the lieutenant governor of Rhode Island. This union produced six children between 1767 and 1776. Thomas, the fourth child, died in 1778 at the age of six. All the rest apparently lived to adulthood.

By all accounts, Leonard was a vital and handsome man, fond of applause. By the early 1770s his fame had spread beyond the boundaries of Woodstock. In 1774, he became chaplain in General Putnam's Third Connecticut Regiment. When the Revolution broke out, Leonard sold his parsonage and marched off to Cambridge with Putnam. Leonard hurled himself into his duties, serving not only his own Regiment but also many others. While at home on furlough he remarked, 'Tho' I have the pleasure of an agreeable wife and pleasant children around me, yet I am at Cambridge sleeping and waking, impatient to know every manoeuvre." ${ }^{.14}$ Leonard's heart and soul were with the Revolution.

When Leonard's term of enlistment expired in January 1776, he appealed to the church to allow him to continue with the army. There was substantial opposition to his extended absence, but the church granted the extension. In late winter of 1777 , Leonard returned to Woodstock and again requested further leave from the church; it was granted. On July 27,1777 , he slashed open his throat and died. The reasons for his suicide 
will probably never be known. Woodstock tradition holds that Leonard overstayed a furlough and was dismissed from the Revolutionary Army. Overcome by shame, he committed suicide. This version of the suicide passed for truth in Woodstock as late as $1860 .^{15}$

Jedidiah Morse was sixteen when Leonard committed suicide. If Morse responded to this stunning event, he left no evidence of it. Yet it is hard to believe that the controversial death of such an important figure in Woodstock did not touch the young Jedidiah in some way. Leonard was, after all, the established minister, and he sought a role in the larger events away from Woodstock over the objections of some in his congregation. The conflict between local duties and aspirations for a role on a wider stage was a fundamental theme in Jedidiah Morse's adult life. There can be little doubt that Morse carried the tragedy of Abiel Leonard in his memory as he pursued his career as established minister to another town in another time.

In addition to the influences of church and town, young Jedidiah was shaped by his family and particularly by his strong-willed father. The elder Morse was the oldest son of John Morse, who died in 1764 of cancer and consumption at age sixty-five. John Morse had married Sarah Peake in 1725 , and the union produced a large crop of sons and daughters. Between 1726 and 1744, Sarah Morse bore ten children. Their luck was good; of the ten children, the first eight lived to adulthood. Mary, the ninth, died at age twelve, and Jonathan, the last, at five. It is possible, however, that the Morses may have lost one or more children in infancy and the event was never recorded. ${ }^{16}$

When John Morse died in 1764, he followed tradition and left the bulk of his estate to his eldest son, Jedidiah, who was thirty-eight when he received his inheritance. We have few records by which to estimate John Morse's wealth. In 1721, when a new meetinghouse was erected, the town granted sixteen people the right to build pews; this list suggested wealth and social standing. The list was topped by Captain John Chandler and continued down to the sixteenth name-John Morse. This implied that Morse barely made it into what might be called the town's elite. The Morse family by 1764 might be characterized as middling to upper-middling.

A petition to the Connecticut General Assembly by the anti-Stiles faction in 1756 supports this conclusion. On the petition the signers also included the amount of their tax lists; Jedidiah Morse's rate was eightyseven pounds, ten shillings. Of the sixty-six people signing the petition, only nine put down a tax rate higher than that of Morse. An additional petition in 1757 from a moderate group seeking compromise has twentyeight additional names, four of which listed tax rates higher than Morse's. Although this suggests that Morse was near the top of the economic ladder in Woodstock, there were complicating factors: some of those above 
him listed estates of much greater value. For example, Samuel Chandlers's estate was taxed at two hundred and seventy-seven pounds, more than three times that of Morse. These two petitions also do not include names of important and wealthy people from the pro-Stiles faction. ${ }^{17}$

John Morse's will also showed that the family was reasonably well off. The father left to his second son, John, Jr., only five pounds "Lawful money ... having before Given him his portion out of my Estate, as much as he ought to have in Justice to him, his heirs etc." To his daughters Sarah, Susannah, and Rebecca, all married, he bequeathed twenty-five pounds and ten shillings. To his unmarried daughter, Hannah, he left eighteen pounds. To Ichabod and Irene Perin, the children of his deceased daughter, Priscilla, he granted twenty-four pounds. To a grandchild, Abijah Child, he left his gun and twenty-four pounds. Jedidiah, as the eldest, inherited the "dwelling house, Barn and all my land," plus five pounds. With this legacy, however, came significant obligations. Most important, John Morse's wife, Sarah, was granted lifelong "use and improvement of all my Personal Real Estate." Furthermore, Jedidiah was required to pay the cash legacies left to the daughters one year after the death of his mother. So, in effect, Jedidiah inherited very little outright except the care of his mother and five pounds in cash. Furthermore, we have no way of knowing whether John Morse's estate actually contained the cash to pay the daughters, but it was clear that the bequests had "to be paid by son Jedidiah as his proper duty to pay in order to procure a Good Title to my Real Estate herein given him."18

The terms of John Morse's will bound the family to the eldest son, Jedidiah, and him to the family. In this way John Morse attempted to create a patriarch out of his oldest son. He used his wealth, and his power to dispense that wealth, to bind the family together with the oldest male at the head. However, by the time Jedidiah inherited his father's real estate, he was already a landowner and economically independent. The petition of 1757 listed him, before his father's death, as a reasonably wealthy man. This wealth had come from his father. In 1746, John Morse sold his son "the westernmost part of my house lott" for three hundred pounds "old tenor," which John Morse estimated to be worth seven hundred and forty pounds to his son. This was probably a transaction motivated by Jedidiah's marriage to Sarah Child on February 19, 1746. When Deacon Morse inherited his father's land, with all the strings attached, he was literally able to put his father's farm back together again. ${ }^{19}$

In 1764, when his father died, Jedidiah Morse, Sr., had already fathered nine children. There would be only one more, Sarah, who died, one-month old, in 1765. While Jedidiah and Sarah Morse ushered ten children.into the world between 1747 and 1765, only five (Jonathan, Calvin, Dorothy, Lydia, and Jedidiah) lived to adulthood. Of the remaining five, none lived 
past the age of eight. The household, however, was always full. First, and most important of all, there was Grandmother. She made very full use of the rights bestowed in her husband's will; she lived thirty-seven years after John Morse's death, dying at age ninety-nine in 1801. Apparently, the Morse homestead was a refuge for other Morses as well. The federal census in 1790 listed three white males over the age of sixteen, four white males under sixteen, and eight females residing in the Morse household.

The father who presided over this family was a remarkable and complex man. That he greatly influenced his sons there can be no doubt. To them he passed on both a material inheritance and a set of values as old as New England. These values called for industry, simplicity, piety, and a profound sense of duty to the community, the church, and God. Jedidiah, Sr., not only taught these values, he personified them. His children saw him labor both on the land and at his trade as farrier, which he described as a "necessary, tho' fatiguing business." He reckoned that by 1810 he had castrated seventeen hundred horses and mules and more than five thousand smaller creatures. This was not, in his eyes, a job; it was a service to his fellow man. The final judgment on his worth as a farrier he was willing "to leave to others to judge." 20

The local records and histories clearly portray Deacon Morse as an incredibly strong and robust man. Farm labor was hard labor, and the farrier business called for a measure of strength beyond that of even the most energetic farmer. Jonathan and Calvin inherited this strength. Like the deacon, they attained their independence by hard physical labor. Jedidiah, the youngest, did not inherit his father's robust health; all the evidence suggests that he, perhaps from birth, was frail and delicate. He was, in a world based on hard and unremitting labor, incapable of establishing himself in that world.

In addition to laboring mightily on his farm and at his trade, Morse devoted countless hours to his community. At twenty-one, he resolved to "do as much good in my day and generation consistent with talents, ability and time as I was able." After 1752, when he was elected surveyor of highways, Morse held a bewildering number of local and state offices. For eighteen years he was a selectman and was the town's representative to thirty-one General Assemblies. Perhaps his most difficult duty was town clerk, a post he held for twenty-six years. In this position he recorded more than twenty-seven hundred deeds, leases, and land transactions, plus all the births and marriages. The task also included summarizing all the town votes and meetings that were a matter of public record. Finally, in 1774, the General Assembly appointed Morse justice of the peace for Windham County, a position he held until 1801. During his tenure in this trying job, Morse handed down 783 judgments, married sixty-five couples, compiled count- 
less rate warrants for collecting taxes, wrote forty-five wills, and served as "Arbitrator and Auditor in many difficult and critical cases."

The church, as well as the town, chose him to occupy important positions. In July 1763, only a month after Abiel Leonard had been ordained, Jedidiah Morse and William Skinner were chosen deacons. As Morse put it, "We stood together in that relation to ye church forty-three years as brothers in harmony and good agreement, and have taken sweet counsel together." Deacon was not the only church office he held; he served as clerk and treasurer of the First Society for twenty years. Finally, the church often chose him for special assignments; for example, he was on the committee to find temporary replacements while Leonard was serving as chaplain. He also headed the committee that sought a permanent replacement.

The devotion to the church was more than a reflection of public spiritedness; Deacon Morse was deeply religious. According to his own account, he "was early devoted to God, instructed and educated by my Christian parents." At eighteen Morse joined a "conference meeting" of young people who gathered on Sunday evenings to read the Bible and discuss religion. After the meetings ceased, Morse continued to think about religious matters and the state of his soul: "I had a great struggle in my own mind about my duty in making public profession of religion, and joining the church. In the meantime, though young in years, I made suit to her that was soon after my beloved wife, and who was a professor of religion . . . by her piety, advice and good counsel, I was more strongly inclined to think and believe it was my duty to obey the command of Christ. ... At length, in about six months after our marriage, I joined the church of which she was a member."

His religious faith was more emotional than rational. For him God was an almost incomprehensible omnipotent being who "is good and gracious, and demands our purist love and affection above all others." This deity also demanded that "our religion be that of the heart" rather than of the head. Morse seemed to care little for fine distinctions in theology; for him your heart was right or it was not, that was all that mattered. An additional element in his religious character was a tendency toward self-abasement that made its way into all aspects of his life. Habitually, he called himself "unworthy." When he looked back on his life, he concluded, "I have reason to blush and be ashamed that I have done so little for God and his Glory when my life has been filled up with large experiences of his goodness and mercy." He believed he was saved, but he spoke as if he was not sure. A "coldness" and "dullness" that he felt in himself puzzled him; he often wondered if he was truly saved.

Morse's tendency toward self-abasement had its roots in what amounted to a ritualized belief in Providence. For him, the self never acted freely; all 
action was decreed by God. He even reduced his relationship with his wife to providential terms. Their efforts to make a good and fruitful marriage were nothing compared to God's design for them. Morse often evoked God's "Holy and all Wise Providence" as the answer to every tragedy, hardship, and human difficulty. The effect was to reduce the human will to virtual insignificance. To a man of this mind, death was the central moment of existence. As he grew older, he became increasingly possessed by "the eternal world which is now before me, and cannot be far distant." Death was "the change," the moment when God's will was fully disclosed, when Providence's plans for you were revealed. Deacon Morse tried all his life to live as if he were saved; his labors for town and church were attempts to convince himself that he was one of God's special children. They were, however, never enough to convince him fully that his heart was right.

We can be sure that his sons and daughters were raised with their father's values as guiding principles. During his life, Jedidiah Morse, Jr., was a strong advocate of hard work, duty to God and man, and providential thinking. Death was for the son, like the father, a crucial issue, an ominous event that gave existence meaning. There were, however, practical matters that a father had to attend to; his sons and daughters had to be taught the ways of God, but they also had to be started in life. To Jedidiah, Sr., his children were an extension of himself, providing him, to a great degree, with a sense of worth. Hardworking, materially successful sons could provide a father with an insurance policy for his old age. This required, however, that the father maintain some measure of moral hegemony over his offspring by using guilt to keep the sense of obligation strong as the children grew older. As we shall see in the next chapter, Jedidiah, Jr., did indeed feel a deep sense of obligation to his father.

In part, the father rooted this sense of obligation by giving his sons a start in life. In 1772, Jedidiah, Sr., sold to his oldest son, Jonathan, approximately sixty-two acres of the family farm at a very low price. Jonathan was twenty-two years old when he received this land, and his father was probably trying to head off any thoughts his eldest might have had of leaving the area. When the deacon died in 1819, Jonathan inherited the rest of the family homestead; he was sixty-nine (he died in 1835) when he came into full possession of his due as the eldest son. Thus, for the majority of his life he lived with, or near, his father and supported him in his old age. Calvin, the second son, was given cash and allowed to leave the area. $\mathrm{He}$ eventually settled in Fairlee, Vermont, married twice, and raised a large family. To his two daughters, Dorothy and Lydia, Jedidiah, Sr., gave some unknown portion of his estate when they married. His youngest son, Jedidiah, received an education at Yale as his portion of his father's estate. Deacon Morse, in dividing his estate among his sons in this way, was play- 
ing a very common game. Like similar fathers in such economic circumstances, he sought both family unity and equality. Unity came by binding at least one son to the family farm and by nurturing this son into the role as patriarch. This is exactly what happened to Jonathan; while he remained subservient to this father, he grew increasingly important in Woodstock, gradually taking over his father's position. The idea of equality also influenced the deacon in his division of his wealth. Perhaps, in an effort not to alienate any of his children, he gave, as best as his resources allowed, each son a start in life. ${ }^{21}$

Was the father able to create a sense of obligation in his offspring? Was he able to secure his old age by helping his sons to succeed in the world? These are very complicated questions. Later chapters will explore the relationship that evolved after 1780 between the father and Jedidiah, Jr. There were signs, however, that the father grew bitter in his old age. In a codicil to his will, added in November 1815, he reduced the cash legacies to all his children. While this was done, in part, as a response to bad economic conditions in New England, the codicil also expressed the father's anxiety about his health, and perhaps a degree of bitterness toward his sons, Calvin and Jedidiah. He claimed that he was reducing the bequests because "my Heirs and Legatees aforesaid had the principle part of their Legacies in Early Life and have had the profits and avails thereof to help them to a Comfortable and opulent living in the World." He also noted that he was "far advanced in life and also a Cripple" and anxious about the "trouble and expense" he would encounter as his condition worsened. He was concerned that "those who may have the immediate care of Me is uncertain" and, therefore, he had reduced the bequests in the original will. He worried that as he grew feeble, his own estate would be eaten away. Apparently, he had little faith that Calvin and Jedidiah would come to his aid. He died four years later, senile and crippled in the home he had inherited more than a half-century earlier.

Deacon Morse and the town of Woodstock were Jedidiah Morse's starting places. He left his family and his town in 1779 and attended Yale College. He became well known as a geographer, a minister, a crusader for religious orthodoxy, and a vocal guardian of the nation's morality. It would be easy to engage in the "must-have" school of biography and claim that his father and Woodstock played a central role in shaping his life as an adult. Any such claims would be based on supposition; during his lifetime Jedidiah Morse said almost nothing about his childhood in Woodstock. Yet there is a very important reason for beginning with this portrait of the town and the family in which Morse spent his early years. During his adult life, which he spent in circumstances very different from those in Woodstock, he celebrated, as an important part of his life and thought, an idealized im- 
age of New England, and particularly of rural Connecticut. For Morse, New England was virtually a perfect society. This myth of a perfect New England runs counter to historical reality. Between 1760 and 1780 the real Woodstock, and the real New England, was a society under strain, fragmenting and breaking in fundamental ways. The idea of religious and social harmony, although it may have continued to exist in the rhetoric of New Englanders, was undermined by growing religious and social agitation. The ideal of happy yeomen profitably working their land was slowly eroded by the reality of land shortages that sent sons west and north in search of better opportunities and sent sons to colleges and into professions in Boston and New York.

Deacon Morse was a classic New England patriarch, passing on to his children time-honored values and methods of child rearing. When the time came, his youngest son would try to inculcate many of these values in his sons. It is good to have the portrait of Deacon Morse, patriarch, on the record, for certainly one of the key issues in Jedidiah Morse's life was his relationship with the image of his father, an image that stuck in his mind like an inescapable memory. Yet along with the image of his republican father, Jedidiah Morse also carried deeply buried in his memory the recollection of his quarrelsome and fragmented hometown. Jedidiah Morse, Sr., and Woodstock do not operate in harmony, historically. The deacon taught lessons about self-sacrifice and the centrality of duty to the commonweal. Woodstock, the commonweal, was fractured and increasingly contentious. 


\section{2. \\ To Yale and the World}

In the midst of revolution, with money in short supply, Deacon Morse decided to send his youngest son to Yale. This decision radically altered the son's life; it forever differentiated him from his brother and uprooted him from the agrarian life of the Connecticut countryside. For Jedidiah Morse, Jr., there would be no farm labor, no inheritance of a father's land and position. He would literally carry his inheritance in his head. That gift-an education-would ultimately take the son to a life in Charlestown, Massachusetts, where he would minister to a flock different from that he had known in Woodstock. Education would also serve as the basis for a career as a widely known writer on geography and other subjects. Woodstock and Charlestown were only seventy miles apart, but miles were not the only measure of distance.

Although his education certainly cut him off from Woodstock and threw him into a new world, the bonds to Woodstock and his father remained clearly visible. The son of Woodstock, who essentially grew up at Yale, shared with his father a deeply religious temperament. He also felt bonded to his father by a sense of gratitude. He showed his gratitude and respect to his father. by remaining amiable to his father's wishes and by assuring the deacon that his son was walking in the way of righteousness and virtue. Between 1779 and 1786, his years in New Haven, Morse began to show the characteristics of the man he would become.

The decision to attend Yale was no doubt forced on Deacon Morse by complex economic and psychological pressures. He had sold a portion of his land to his eldest son and faced the problem of setting up Calvin in some sort of life. As for Jedidiah, there were other considerations. Jedidiah's son, Richard C. Morse, provided a clear statement of these considerations in a letter written after his father's death:

Owing to my father's delicate constitution, and, perhaps, because he was the Benjamin of the family, my grandfather would not subject him to the hardships of a farm, but gave him a liberal education. Some of the neighbors censured him for this seeming extravagance. But when they found that he still retained his domestic comforts, that he met his other liabilities, and yet paid all his son's college dues, and when they saw throughout the life of the old gentleman the reverence and respect shown by the son, who sought the father's counsel, shaped his plans to meet his approval, 
and even was influenced in accepting the call to Charlestown by the desire that the two might be near each other, they admitted that my grandfather had done wisely, and was reaping his reward. ${ }^{1}$

Clearly, Deacon Morse gave his youngest son an education that came with strings attached. Although the years at Yale separated the son from his parents and his hometown, young Jedidiah continued to feel dependent on his father, who had suffered the censure of neighbors and friends as he paid for his son's education at Yale.

Beneath the decision to send young Jedidiah to Yale there lurked perhaps even more profound realities. In Woodstock in the eighteenth century, one of the most, if not the most, fundamental purposes of labor was to establish both personal and family independence. In the 1770s, labor still meant, for the vast majority of Americans, labor on the land. Hard, but intermittent, labor slowly produced land ownership, independence, and personal competency. The desire for personal security, not endless accumulation, had become a central value in the Anglo-American tradition, as the memory of feudal domination and dependence faded. Families prized children as a resource; strong, vigorous, hard-working males could advance the family's interests by working for cash or by gleaning the maximum production from the family's land. Because of his chronically poor health and the deacon's limited resources, Jedidiah was seemingly set free from the family's collective quest to gain and maintain independence and competence. But as Richard Morse's statement suggested, this freedom was only an illusion. The cost of a Yale education was bearable and the deacon reaped his reward in the continued deference and respect that flowed back to Woodstock from his youngest son. It is not too much to suggest that Jedidiah was expected to pay for his education in more concrete ways. As we shall see, Jedidiah remained economically involved with his family's interests until his father's death in $1819 .^{2}$

Morse, himself, has provided one of the best short descriptions of New Haven and Yale in the 1780s. The city of New Haven was seated "round the head of a bay" and covered "part of a large plain, which is circumscribed on three sides by high hills or mountains." The town spread out around a public square "on and around which are the public buildings ... a State House, College, Chapel, three churches for Congregationalists and one for Episcopalians." Morse thought these buildings "all handsome and commodious" and the square with its many trees "convenient and delightful." The square's attractiveness was diminished by the presence of the burial ground and the public buildings that occupied a considerable portion of it. The streets of New Haven were lined with trees "which give the city a rural appearance." There were about five hundred houses and 
about three to four thousand inhabitants. The death rate, an important statistic for Morse, was one per seventy citizens per year, a ratio that proved "the healthfulness of its climate." "Indeed," Morse concluded, "as to pleasantness of situation and salubrity of air, New Haven is not exceeded by any city in America." 3

When Jedidiah Morse arrived at Yale in 1779, the college was just beginning to feel the presence of its new president, Ezra Stiles. In many respects, for students like Morse, Stiles and Yale must have seemed almost identical. In addition to his duties as president, Stiles came very close to being the entire professorate. As professor of ecclesiastical history he lectured each Thursday on the history of Christianity. Saturday evenings he held forth on some aspect of those great pillars of the Calvinist faith - the Westminster Confession and the Savoy Declaration. In 1781, Stiles took over from Nehemiah Strong as professor of mathematics and natural philosophy. Stiles attempted to provide some coherence to the students' intellectual development by offering two lecture series, called the Cyclopaedia of Literature and the Cyclopaedia of Science, which ranged widely over all learning. Irregularly, he taught oriental languages (in addition to Hebrew) and moral philosophy, and he even gave instruction on the nature of vision and the structure of the eye. As the students were about to graduate, Stiles provided them with career guidance in a series of talks on the learned professions: law, medicine, and the ministry. ${ }^{4}$

When Stiles became president of Yale in 1778, the college was at a low ebb. The Corporation, a board of clergymen who ran the college, had effectively alienated much of the state. Yale had come under the influence of the New Divinity, which was, in short, the intellectual embodiment of the Great Awakening. By the 1770 s, the emotionalism and radicalism had drained away from the movement and it had become increasingly a theological stance pursuing intricate and often arcane religious questions. New Divinity ministers, which Yale produced in abundance, grew increasingly unpopular, as did the college at New Haven. When Stiles arrived in 1778, he was well aware of this anticlericalism and drew up a plan to diversify the college's objectives. With an eye on Connecticut's practical needs, Stiles thought the college should eventually have a professor of physic to help produce doctors and a professor of law to train lawyers and prepare students for government service. For the first time in its history, the college had a president who saw Yale as a university meeting many needs instead of a college turning out ministers. ${ }^{5}$

Yet the president's plans for new professors had to take a back seat to more mundane concerns in the late 1770s. Perhaps his gravest problem was feeding the students. Food, while the war continued, was always difficult to come by. In December 1778, Stiles was forced to dismiss the 
students early for an unusually long winter vacation. School did not reopen until February 1779, and Stiles begged and borrowed enough food to keep the school open. the rest of the year. On July 4, 1779, Stiles was conf ronted with a threat more exciting than food shortages-the British attacked New Haven. When news of the imminent invasion arrived, Stiles dismissed the college; some ran for home and others went out to fight the British. Professor of Divinity Daggett grabbed his fowling-piece, hurled his fifty-one-year-old body onto his old black mare and rode furiously in the direction of the British, ready for action. The divine-turned-sniper was soon captured, mistreated, and forced to march barefoot under the broiling July sun. He never fully recovered from the experience. Professors and volunteer students, however, could only delay the British invasion; enemy troops soon captured the town. Although the British engaged in the normal plundering, they did not burn the town. If they had, Jedidiah Morse's life might have been different: there would have been no college for him to attend in the fall of 1779 . The British certainly considered burning the town; their commander noted in his diary that New Haven was "a very considerable town" and that the college "might with propriety be styled the parent and nurse of rebellion."

When the college reopened in October 1779, with Jedidiah Morse among the freshmen, the problem of invasion was gone. Although food shortages continued, the Revolution actually began to stimulate the growth of the college. Enrollment grew from 124 in 1778 to 265 in 1783 . The war had made some Connecticut farmers increasingly prosperous, and they used some of the surplus cash to pay college bills. Equally important, college students were excused from service in the militia. Deacon Morse, for example, wrote Governor Trumbull and obtained an exemption from military service for his son. The father argued that Jedidiah's frail health and his greater usefulness as a student were reason enough to exempt him. As the large increases in Yale enrollment suggest, such exemptions were not uncommon. For example, the class of 1785 was the largest in the eighteenth century, totaling seventy men, a number not equaled again until $1806 .^{7}$

The growth in the student body was not an unmixed blessing. The influx of tuition payments helped the college's finances, but the growing number of students led to increased disorder. To some extent the Corporation was responsible for this. In 1777, the Corporation had forced the resignation of three of the four tutors at the college. Tutors, in addition to their teaching responsibilities, were central in maintaining order. Stiles, who became the sole professor when the Corporation forced the resignation of Professor Strong, aided by inexperienced tutors, found it hard to control a student body growing larger each year. Student misbehavior reached a peak of sorts in 1782, when between twenty and thirty students 
literally destroyed what remained of Old College. In response, Stiles expelled four students and rusticated (sent them into the country to study with a minister) twelve more. Stiles used the demolition of Old College as an excuse to build the first new building of his presidency. By Christmas of 1782, Yale enjoyed the use of a new kitchen and dining hall. ${ }^{8}$

Thus, the Yale that Jedidiah Morse attended was a thriving institution, at least in relative terms. There were plenty of students, the books were balanced, and new buildings were going up. As Edmund Morgan has concluded, "Stiles had made Yale a crashing success and everybody knew it." Stiles had, however, done more than balance the books; he had created a revived sense of college spirit and tradition. Perhaps more than anything else, Stiles loved ceremonies; during his term, commencements in the fall and quarter days (miniature versions of commencement at the end of each quarter) became great occasions with parades and endless oratory. The president also insisted on a rigid hierarchy with the president at the top. Freshmen, of course, were the mudsill in this arrangement, but clearly the system was designed to instill deference to superiors and a hierarchical frame of mind in everyone at the college. All students, for example, were required to remove their hats in the dooryard of the president's or a professor's house and to be hatless when within ten rods of the president, eight rods of a professor, and five rods of a tutor. Given the destruction of Old College Hall and the countless outbreaks of less serious student pranks, Stiles's insistence on ceremony and hierarchy must have existed in an uneasy tension with the normal high spirits of students-increased perhaps by the equalitarianism of a revolutionary age. ${ }^{\text {? }}$

Jedidiah Morse exhibited little evidence of high spirits while at Yale. He was an intensely serious and religious young man who condemned the student hijinks of his day. He suffered much from poor health and poverty. His letters home often contained news of some kind of ailment, ranging from persistent headaches to stomach disorders. His poverty was just as persistent; in March 1781, he wrote his father, "I have disagreeable news to tell you ... I have got no money, which I hope you will not think strange of all things considered; and more my Breeches and Shirts are almost worn out." In 1781, Morse applied to the president to go home early for Spring vacation and Stiles agreed. His clothes had reached such a state of disrepair that he asked his father for "a pair of Breeches to ride home in and also boots ... for my shoes are almost worn out." By coming home early he saved on board, which was his greatest expense, amounting to almost seven pounds per term compared to only one pound for tuition. ${ }^{10}$

This poor and frail student exhibited a deep sense of dependence and gratitude toward his father. He described his situation in 1782 to his father as one in which "I enjoy every advantage I could reasonably Desire- 
to improve them as I ought is all I wish for." These advantages flowed from "God, the bountiful Benefactor" and from "my parents who are the Means of my enjoying so great Privileges." In a typical outburst he wrote:

I am sensible that to be highly grateful for all the favours bestowed on us by our Parents-to show this Gratitude by a strict attention to their Wants and a voluntary desire to supply them, by soothing their Cares, lightening their sorrows, supporting the infirmities of Age and making their Life as easy and comfortable as possible, to pay all these Honours and make these returns is to pay the oldest, the best and greatest of Debts, next to those we owe to our supreme and common Parent. They are founded on Nature and are agreeable to the most fundamental Laws of Gratitude, Honor, Justice, Natural affection and Piety. To live according to these Rules will be my greatest Happiness and my most constant endeavor. ${ }^{11}$

Immediately following this statement, the loyal son requested that his father "send up a sley load of Provisions soon, Beef, flour, Butter and Cheese are most wanted." The son paid his debt in testaments of gratitude; the father increased the son's indebtedness by sending provisions.

However, as Morse said, the greatest debt was due not to one's parents but to God. Indeed, Jedidiah's growing religiosity, his developing relationship with God, bore a striking similarity to his relationship with his father. During most of his time in New Haven, with the exception of several small revivals of religious feeling, religion was in decline at Yale. Morse responded strongly to the lack of interest in religion at Yale, referring to the early 1780 s as "this Period of Universal Depravity." He felt that religion must be "a Matter of the greatest Moment and concern and our chief Business and Study during this our momentary existence" and saw as rational his decision to make religion central in his. For him it was

a matter of the greatest astonishment ... that Mankind, made rational Beings, capable of distinguishing between good and Evil, with the additional Advantage of Divine Revelation, who are conscious to themselves that they are accountable creatures and on the best reflection must feel themselves exposed to everlasting Destruction-I saw after all these advantages and warnings that they will go on in such a careless heedless manner, like irrational Beings, that they will be so easily seduced by the Charms and Allurements of this World which, in itself considered, is as vain and worthless as those deluded Persons who put their confidence in the enjoyment of it. These cannot be Matters of mere Speculation, they are realities of Eternal Importance. ${ }^{12}$ 
Indeed, for Morse, they were eternal. For the next four decades he would maintain that a belief in basic Christian doctrines was rational and obvious. He would maintain that revelation and reason blended together to force the truly open minded toward belief. Death, or "everlasting Destruction," would loom large in his thought as an anxiety-provoking reality determined by Providence as a goad to the heedless. Death was a constant reminder that man was an accountable creature, and Morse would, for the rest of his life, denigrate the "Charms and Allurement of this World" and portray those who pursued them as "deluded Persons."

For Morse, there were many such persons at Yale. He assumed that, released from restraint, the students would run wild, and he often praised college authorities for standing firm. As he wrote his father, after the destruction of Old College, "In such a multitude of youth where there is not severe discipline kept up jargon and confusion would soon be introduced." He complained that he was virtually alone among a disorderly and profane student body. In time, these feelings grew into a sense of precaution and fear. In March 1781, he wrote his father, "I am now in a very critical situation exposed to the ridicule of the ungodly multitude, one false step is of dangerous consequences to those that mean to be advocates for Religion."13

These feelings were overdramatized, but they probably reflected a generally accurate appraisal of the situation at Yale. It was a dull time for religion. In 1781, for example, Stiles noted in his diary that less than 10 percent of the students took communion at the college chapel. Morse probably stood out as unusually serious and devout in a time when deism and indifference were on the rise. Morse also may have isolated himself at Yale by rooming, for most of his stay there, with two other Woodstock boys, Abiel Holmes and Stephen Williams, both of whom went on to become ministers. Occasionally, Morse would refer to their living arrangements when they were boarding in the town as "our little Commonwealth," suggesting that there existed a small group of Woodstock Christians that contrasted sharply with the bulk of the student body.

Also, unlike most of the students at Yale, Morse and Holmes joined the college church. Although attendance at chapel was mandatory, few students joined the college church; many either looked forward to joining the church in their hometown or had already done so, and many simply rejected the idea for other reasons. For example, there were a number of Episcopalians at Yale who were compelled to attend the Congregational church at Yale but, of course, they could not join. Apparently, Morse and Holmes decided to join during one of the periods of heightened religious feeling. Morse's description of his decision to join the church at Yale sug- 
gests that the act was, at some level, a rite of passage in which he exchanged, at least symbolically, his dependence on his father and mother for a dependence on God and Jesus Christ. In February 1781, he wrote his parents that he wished to inform them of something that was "of the last importance to me and of no small consequence to each of you." "With great Anxiety" he had decided to make a "solemn Dedication of myself to God my Creator!" He made it a point to inform his parents that President Stiles had helped lead him to this decision. Morse mentioned no intense emotional experience; the decision to join was the product of calm discussion with the president, who was also the pastor of the college church. Why did Morse not join the church at Woodstock? It was, after all, very much his father's church. Morse, in the letter to his parents, made all the appropriate statements concerning his love for, and dependence on, his parents, but he also conveyed the message that he wished to stake out some area of independence. In some small measure, the son was telling his parents, or trying to, that their hold on him was reduced.

Most central to this rite of passage was Morse's belief that by devoting himself to God he was repaying his parents. He remembered "the many profitable Instructions you have so often repeated" and asserted: "How can I better repay you for all your trouble and concern for me from my infancy than by giving myself to that God that made me, me thinks I can do it with the greatest Degree of Pleasure and Satisfaction and humble Dependence on Jesus Christ the Mediator and I pray that it may be done in a Manner acceptable and well pleasing to him. I feel a secret inexpressible Pleasure arising in my Breast, mingled with a certain awe and reverence of God." 14

This was a very subtle and partial rebellion, if it can be called a rebellion at all. More accurately, Morse was attempting to establish some small sense of autonomy in his life without completely cutting himself off from his parents. He informed his parents that he still had "need of your advice and instruction," but "since I am deprived of your advice I hope I am not out of your Prayers." If his father had read carefully, he would have heard his son inform him that new models and guides had come into the son's life. President Stiles had certainly become one such father substitute, and Morse also asserted that "I have good Instructors and Lessons of good Characters to advise with, who may in some good measure make up the Loss of you." Yet clearly Morse was attempting to escape one form of dependence by taking on another. His submission to God and Jesus Christ was a partial psychological replacement for his submission to his parents with one very crucial difference. By 1781 , Morse must have decided that he was going to spend his life as a minister. In this context, religion became both a form of submission and a way of gaining the status of father. 
As a minister he would be a father of sorts, a man who stood at the head of a flock of children, guiding and disciplining them. ${ }^{15}$

Morse was, however, unable to explain his decision to become a minister in any other terms but those that would have satisfied his father. Morse always described the ministry as a calling demanding a stern sense of duty and a rejection of earthly pleasures and pride. After he received his first invitation to preach, he rejected it because he did not want to "indulge Pride in any degree because I am called upon so soon to do that which will probably hereafter be my Duty." He wrote his father: "Pride ill becomes a Minister of Christ, especially when the Profession runs so low in the esteem of the World in general. No motive but Duty and a desire to promote the highest Interest of Mankind would ever induce me to be a Preacher. And these are Motives abundantly sufficient. As for the esteem and applause of the World, I despise them when they come in competition with Duty. You are by this time assured, I hope, that I am determined to spend my Life, my Abilities and my $A L L$ in the glorious Course of the King of Kings." 16

This statement introduced a basic theme in Morse's life. His attempt to assure his father that he was truly called to the ministry, and that pride and the rewards of the world were of no interest to him, was merely the first of many such statements he would make in his life. Periodically, until his death in 1826, he was accused of courting fame and riches and of neglecting his duties as a minister. Certainly there was a basis for such charges; he devoted great effort to writing and selling his geographies and to establishing a reputation on the national scene. His flock in Charlestown and his father would persistently criticize him for neglecting his duty. For Morse there was, from his Yale years onward, a constant tension between his sense of duty and a desire for material success and self-aggrandizement.

By choosing to become a minister, Morse placed himself in a very ambiguous situation. The congregational clergy, after the Revolution, were characterized by soaring hopes and haggling doubts and anxieties. From Stiles, Morse would have absorbed a generalized euphoric, even millennial, outlook. Stiles argued that the new American nation was linked with the rise of "true religion." "Holiness" was, for him, "the end of all civil government." The American nation, with its free political institutions, would produce a religious life of harmony and benevolence in which all sects would be independent. Looking into the future, Stiles saw all the religious groups growing into "respectable bodies." But in a free society, where minds were freed from secular and religious oppression, the churches that would dominate were "the Congregational, consociated and Presbyterian." When the American population reached forty million, these churches would, Stiles predicted, contain thirty million souls. From Morse's point of view, this rosy 
prediction made religion look like a growth industry and the Congregational church a leader in bringing the light of true Christianity to a willing people. ${ }^{17}$

Stiles's optimistic vision, however, could not obscure the fact that, in 1783 , religion in general and the Congregational clergy in particular were beset by substantial problems. Certainly Morse was aware that in the last half of the eighteenth century, rationalists and revivalist pietists had united in the quest for religious freedom from a tax-supported church that promoted an established creed. Increasingly, Americans of all classes were coming to see religion as a matter between the individual and his God without institutional mediation. The established Congregational church, to which Morse was to devote himself, was, in contrast to Stiles's optimism, very much under attack. This attack was subtle and insistent, but nothing represents it so much as the very clear chànge in the structure of New England's elite. Ministers had once dominated New England life, but in the postrevolutionary world, men such as Jefferson, Franklin, Madison, and Hamilton had clearly shouldered aside the clergy and taken over as the elite. This transition was apparent at Yale in the 1780s. Founded to provide a learned ministry, Yale had gradually become a training school for an elite that, more often than not, chose vocations other than the church. During its first quarter century, 67 percent of Yale graduates became clergymen; between 1725 and 1750 the rate dropped to 42 percent, and between 1750 and 1800 it sagged to 28 percent. ${ }^{18}$ Yale was still very much in the business of training a social, economic, and cultural elite, but the clergy was shrinking as a part of that elite.

Whatever tensions he may have experienced, in 1783 Morse overtly committed himself to the ministry. His letters home often contained effusive expressions of his desire to commit his life fully to his holy calling and to submerge his being into the cause of Christ. Two very different pieces of evidence, however, reveal another side of Morse, far more selfabsorbed than the one he revealed in his letters home. Both date from 1782, Morse's third year at Yale. The first was a packet of letters entitled "A Correspondence by Letter with an Absent Friend." Actually, there were letters to a number of people-"Brother," "Aunt," and "Eunice." The packet was probably an attempt by Morse to refine his letter-writing skill and they were probably never sent. These letters afforded Morse a secret world where he could express feelings that had to be excluded from his other letters, particularly from letters to his father. In the letter to Eunice, for example, he praised "solitude," in which "the Mind, uninterrupted by the Care and Business of Life may study $S E L F$, the most profitable of all Sciences." He recommended, Pope's line, "The Proper Study of Mankind is Man"; a motto he placed on the front of the packet. ${ }^{19}$ 
This packet of letters also revealed a less-serious young man interested in romance and fun. Several of the letters were little more than thinly veiled love letters. One even contained a love poem of sorts:

\author{
Lilacs are by plain direction \\ Emblems of a double kind \\ Emblems of your fair Complexion \\ Emblems of your fair mind-
}

In the letters to the ladies, Morse of ten described his social life in New Haven as "polite," apparently meaning gay but genteel. He went to "the Dancing School" three times a day to enjoy polite company but admitted he found the dandies there "a little affected."20

Morse left a second document from his college years that illustrated other elements of his personality. Apparently, Morse kept a diary while at Yale, of which only a fragment from the spring of 1782 has survived. It dealt with a period from April to early August and contained entries made in New Haven and Woodstock. At one point in April he admitted that he felt "a pretty good disposition for study" but "was indifferent with regard to religion." At home in Woodstock he played the ladies' man. Morse devoted whole days to sailing on the pond and "playing ball with the ladies." He recorded that, among his social set, marriage games called "Pawn Plays" and "Woo the Widow" were popular. In the middle of May he heard a sermon that suggested religious doubt was not abnormal; it was a tool that Christians should use to force themselves closer to Christ. "This I immediately took to myself," he noted.

The diary also recorded a ghoulish confrontation with death. In June, his friend Ripley persuaded Morse to be inoculated against smallpox. This was dangerous; the procedure called for the patient to contract a case of smallpox, recover, and thus gain immunity against the disease. As things turned out, all went well for Morse, but not for Ripley, who never recovered from the inoculation. As Ripley slowly succumbed to the disease, Morse remained locked in the "smallpox hospital" with him. Morse recorded that they calmly discussed Ripley's chances for salvation-Ripley was doubtful, but "would trust in the Lord." About an hour before he died, Morse noted that his friend "spread out his hands in a Prayerful manner and by the motion of his lips seemed to pray for the space of 12 or 15 minutes." Because Morse could not leave the hospital, he was forced to spend one night with Ripley's corpse. Morse seemed compelled to record his response: "Words are totally insufficient to express the melancholy and horror of this Night. Imagination can't paint a more shocking figure than the Corpse." 21 
Only rarely would a modern American conf ront death so directly. Jedidiah Morse had confronted the reality of death early in life. In 1765, when he was only four, both his younger sister and brother, Leonard and Sarah, had died as infants, a tragic, but not uncommon, event in eighteenthcentury America. Morse's experience in the pest house with Ripley was also not that uncommon; most Americans of the time probably had similar experiences, and they probably responded as Morse did by evoking God and Providence as an explanation. On the day he finally left the hospital he asked himself why Ripley had died and he had been spared. He concluded that "it was heaven's Decree and must be fulfilled." For most of his life Morse would be anxious about death; he was always curious about death rates in various parts of the country and habitually presented death as one of the reasons compelling a belief in the Christian faith. The night Morse spent with Ripley only reinforced a fundamental anxiety. ${ }^{22}$

Indeed, by the time he graduated from Yale in 1783, Morse had developed a personality characterized by anxiety. As he confronted the prospect of being "let loose into the wide World," he felt "like a ship without anchor in the wide ocean of the world." He hoped that as a Yale graduate he would be better able to promote true religion, but graduation also produced "gloomy" and "dreadful" feelings "when I reflect on the degenerate, the melancholy State of Mankind." Morse was particularly depressed and anxious because "I must be obliged to live among those who are constantly inveighing their dear Lord and Redeemer afresh-who are despising his Life and rejecting his offers of Salvation." Morse was one of the few devout Christians at Yale, and this statement no doubt reflected his sense that most of his classmates were corrupt or, at best, indifferent concerning religion. The statement also reflected an aspect of Morse's personality; he was beginning to see the world as divided between the saved and the damned. Together with his own affirmation of Christian beliefs, and his submission to God, came a need to condemn and fear those who followed other paths. Morse's sense of his own identity as a Christian was deeply troubled by the existence of others, of a world, that took on other identities and rejected the call to submit to God. ${ }^{23}$

The slackening of religious fervor in Woodstock sharpened this feeling of anxiety and depression. While home on vacation, Morse saw firsthand that both young and old in Woodstock were cold and indifferent to religion. He saw "Professing Christians" who were "cold and lifeless in Matters of everlasting consequence and their example inspires the Sinner with fortitude to go on in the broad road to Destruction."24

Morse's anxieties had other roots as well. He planned to continue on in New Haven and study theology with Jonathan Edwards, Jr., and Samuel Wales. There is evidence that his father was unable or unwilling to sup- 
port him any longer. In the same letter in which he revealed his religious anxieties, Morse pleaded with his father for money: "Never was a person under so great necessity for Money as what I am at present-if it be by any means possible send me some at Examination.... We can't breath N. Haven Air without money." Morse knew that 1783 was "a trying time" for his father, but he hoped that this would be the last time he would ask for support. ${ }^{25}$

For the next two years, Morse studied theology and attempted to support himself by teaching, and eventually preaching, in the New Haven area. To some extent, he became financially independent of his father and accepted the idea that he should start sending money home. Often he paid lip service to the idea of repaying his debt to his father but pleaded poverty. In April 1784, for example, he wrote home that "I fear I shall be able to bring home but little Money there are so many ways to spend it, it is almost impossible to keep any."26

During this period Morse continued under the influence of Stiles, whom Henry May has rightly labeled "the best specimen of the special New England compromise between Protestantism and the Enlightenment in the period just before this compromise broke down." Wales and Edwards the Younger must have had an influence, but the record is almost totally silent. Edwards, no doubt, exposed Morse to New Divinity theology, but this was balanced or neutralized by Stiles, who apparently harbored no great love for Edwards. Perhaps, most importantly, young Jedidiah, the preacher-to-be, was introduced to the world of ministers and their tricky relations with their congregations. Edwards, for example, had a very difficult and unhappy connection with his flock in the White Haven Church. Wales, unlike Edwards, was a professor at Yale and very much in charge of the campus chapel. It is very possible that Wales played a part in Morse's unusual decision to join the college church during his undergraduate days. Yet although Morse was subjected to a number of influences immediately after his graduation, he responded fully and completely to none of them. ${ }^{27}$

In fact, between the time Morse graduated from Yale in the fall of 1783 and his acceptance of the call from the First Church in Charlestown in 1789, Morse lived through a moratorium, a delaying action. For nearly six years he occupied a space between childhood and adulthood characterized by uncertainty, anxiety, and a sense of divided identity. His decision to pursue graduate study in theology allowed him two years more in New Haven during which he had to make no permanent decisions about his life. It was during this unsettled period that he discovered geography and writing. While teaching in New Haven he discovered that his students lacked good geography texts that described their newly independent nation. In response to this need, Morse quickly produced Geography Made Easy (1784), a simple book for students. Much to his surprise and plea- 
sure the book began to sell very well; as it did, a new element was introduced into Morse's life. He liked writing books and he liked the money that came with selling them. While he continued to profess his desire to devote his life to the ministry, he was also strongly attracted to writing and its financial rewards. ${ }^{28}$

Morse's attempt to combine the ministry and a budding career as a writer took an interesting turn in 1786. In the spring, Stiles chose Morse to be a tutor at Yale. Morse's decision to accept this position was based on his, and his father's, belief that it was too soon for Morse to settle permanently into a church. Late in 1785 and in early 1786 Morse received several offers from churches. Significantly, he sent the offers on to his father and begged his advice. In February he agreed with his father's view that he was "too young in preaching - too ignorant-too imprudent to settle yet." Both agreed that the son should extend his moratorium before he settled in a permanent position. Morse's position as tutor began in June 1786 , but by October he was ready to give it up for a chance to travel to Georgia. Abiel Holmes from Woodstock, Morse's classmate at Yale, offered him the chance to take over his pulpit in Medway, Georgia, temporarily; in exchange, Holmes would take up Morse's position as tutor. This unusual switch allowed Morse to combine his ministerial career with his ambition to be a geographer. The trip south would allow him to collect firsthand geographical information. The success of Geography Made Easy had spawned dreams of a more ambitious work, one that required direct observation, particularly of those areas of America with which Morse was unfamiliar. Between 1786 and 1789, when Morse published The American Geography, he attempted to balance his career as a minister and his desire to write and publish for profit. ${ }^{29}$

During the years between Yale and Charlestown, Morse also revealed his anxieties about sexuality and marriage. While teaching in New Haven he wrote a play for his students to perform at the year-end exercises. Entitled "A Dialogue," perhaps to avoid the day's negative view of drama, it was, in fact, a play with five main characters and a number of roles for servants. The piece presented two marriages - one good and one bad. The good one was based on friendship and cordial respect between the partners, Sir George Clarendon and his wife, Lady Clarenda. Sir George, for example, delivered a long speech condemning men who were attracted to feminine beauty, fine dress, and ornament. "The Beauties of the Mind," he suggested, should be love's true basis. In creating the portrait of a bad marriage, Morse gave vent to some of his anxieties. The badly matched pair, Lord and Lady Bevil, fought constantly, but Morse made it clear that the fighting had not started until the wedding night. During their courtship the two had been deliriously happy. Lady Bevil, for her part, had been 
attracted by her husband's "high sounding title" and immense wealth; she admitted that just after the marriage Lord Bevil had begun to act "as tho he had been bred among the Hottentots." 30

Morse gave Lord Bevil a peculiar personality. For one thing, he habitually became enraged at his wife and at women in general. He ranted that "there's a secret curse entail'd upon the Name of Wife." In what was, by far, the strangest scene in the play, Lord Bevil rudely dismissed his wife and called for a servant, whom he beat with a cane for no reason. He ordered the servant to bring him "two fowls" and commanded that the servant "let no woman see them, much less touch them." After the servant leaves, Lord Bevil delivered a soliloquy: "Blood of fire what's got into the World-People are certainly bewitched and it must be because there are too many Women among them-Oh Woman thou fit subject of the Serpent's Artifice. Why was I so disgraced as to be born of such a mischief maker-I'll be drown'd if I hadn't rather be hang'd if it wasn't for the pain of shame on it than to have it said I was born of a Woman-a woman, a tormenting, mischievous, bewitching creature-Methinks the bare thoughts of being Freed from women will take away all the pains of dying."

The servant returned with news that the fowls were ready. Lord Bevil ordered the servant to bring them and to fetch him a wig. He took off his cap and gown, put on the wig and demanded a "looking Glass." As he admired himself in the mirror, he said, "how wapsided it is, well it isn't strange the World is turn'd upside down." He turned to the fowls and began to eat, which produced this incredible outburst: "Methinks this Meat, this sauce this bread and everything tastes Womanish-I shall be poisoned-I shall be bewitched. Also I begin to swell I feel giddy (Kicks over the Table snatched off his Wig) Oh fortune-fortune, suffer me not to be doubly disgraced by living and dying by the hand of a Woman-I'll like good old Judas I'll hang myself and rid me at once of the world of Woman and Misery-(Exit in a Rage)."

A strange scene, indeed, to appear in the graduation exercises of a proper coeducational school in 1784 . Was Morse attempting to be funny? If so, it was totally out of character. The rest of the play was written in ponderous and deadly serious language and, in general, Morse was among the gravest and most humorless of men. In fact, the scene suggested the existence of a profound anxiety in Morse; an anxiety that he was able to exorcise, at least in part, in this scene. Morse may well have come to sense a feminine element in his own personality. He was now, after all, fully alienated from the masculine world of hard physical labor and rapidly taking up the effete identity of teacher and minister. His constantly frail health, his habitual dependence on his father, his desire to submit to his father and other authorities may have, in the context of the times, created 
a feeling in him that he was more feminine than masculine. A number of the elements in the scene point toward this interpretation. Bevil removed his cap and gown, which, as he had just returned from a morning of business, might be construed as symbols of manliness, and donned a wig and admired himself in the mirror and claimed the world was turned upside down. $\mathrm{He}$ ordered food untouched by women but sensed that it "and everything tastes Womanish." In response he swelled, began "to feel giddy," and snatched off the wig. In response to this feeling, he claimed to desire suicide, "like good old Judas" the betrayer, over "the world of Women and Misery." 31

Morse may have given voice to some of his anxieties in creating the Lord Bevil character, but the clear meaning. of the play tended to resolve them. The unequivocal point of the play was to present friendship, however vague and undefined, as the best basis for marriage. Sexual attraction, titles, and wealth served only to delude and ultimately to disappoint; Morse has Lady Bevil summarize this view:

Come then Content, sweet Soother of the Soul Glide thro my breast, and all my pains control

I know tis true, by said experience know Thou art not from among the rich below

None shall behold thy mild and blooming face Or e'er possess that best of Blessings Peace,

Until a faithful Friend their heart shall choose Who will his Balsom to their Woes diffuse

Friendship's the chiefest good the balm of Life The bane of faction antidote of Strife-

The gem that virtuous breasts alone can grace The sign of Patience and the Seal of pace,

Love chains the Hart as Steel the Limbs confined, Friendship's the gentle bond of faithful minds

A Friend's a pleasure when great Wealth is none Of all Enjoyments the most useful one

He doubles pleasure Sof tens every pain Then ask for this when true content you'd gain. 
This play, or at least its conclusion, suggested that, during Morse's moratorium between college and his permanent settlement at Charlestown, he advocated a set of attitudes that featured a rejection of discord, conflict, and luxury. Morse extolled friendship as a crucial element in any truly happy life and suggested that the young people who saw and performed the play learn to control their emotions and come to love simplicity and frugality. Sir George, at one point, stated "I believe young persons entertain mistaken Notions concerning Love in they are apt to imagine it consists in a kind of Enthusiasm which is often excited by the sight of a handsome face, a fine rich Dress or a gentell graceful Air-such Persons me thinks are in Love with external Ornaments."

Morse made a clearer and more extensive statement about his aversion to luxuries and mere ornament several years later at the Yale commencement exercises in which he received his master's degree. President Stiles had turned the graduation exercises into grand occasions, replete with processions, speeches, and disputations. In 1786, Morse and David Daggett debated the question "Whether sumptuary Laws ought to be established in the United States." Morse took the affirmative side, and his position was printed along with Daggett's in the New Haven Gazette and Connecticut Magazine. This marked Morse's first appearance as a political advocate and was the first substantial expression of his social and political views. ${ }^{32}$

Morse defended the idea that "superfluous Expences in Diet, Dress, and Equipage ought by law to be restricted in the United States." Granting that such laws inhibited liberty, he claimed "this was true in appearance only." Morse's position was based on the assumption that Americans wanted a strictly republican government. He argued that republics needed sumptuary laws, whereas monarchies did not. A republic was, in his view, based on the virtue of the people and it was in the government's interest to use law to control the habits of the people. To support this position he cited Montesquieu and reviewed the record of the Greek and Roman republics, which he saw as failures because their populations lost their virtues in an unseemly scramble for luxuries. Luxury had "a direct tendency to enervate and destroy virtue."

Morse defined virtue as the "the vigorous exertion of a rational mind, for the promotion of his country's welfare. Can then the sluggish, barren, epicurrean [sic] soul, be a fit receptacle for public virtue?" True virtue was denied to those "whose views are circumscribed within the contracted limits of all-important SELF, and whose vanity is gratified at the expense of his country's welfare." Anyone entranced by vanity and self could not "possess that virtuous, manly soul, which animates every true republican, and which in all its operations aims at the public good."

This view of the situation followed the same pattern as Morse's religious feelings. The American Republic and the Kingdom of God served 
in Morse's mind as higher purposes, ones that required from Americans self-abasement and rejection of selfishness. Psychologically, the commitment to a republic and to Morse's idea of a religious kingdom were virtually identical. Both the religious and secular republic would be known by the moral character of its citizens, and the success or failure of both hinged on the behavior of those citizens. Morse essentially transferred his religious temperament to the contemporary political situation. His acceptance of the notion that a republic should be based on the virtue of its citizens was rooted in the similarity of that idea to basic religious ideas that had become an integral part of his thought long before 1786. In all of his correspondence prior to 1786 , there was not one mention of the Revolution. Throughout his undergraduate years at Yale, while the Revolution slowly made its way to victory, Morse wrote of nothing but religious matters. It was not until the Revolution had succeeded and the problem of establishing a stable government arose did Morse find a way to participate in the public debate. The image of a virtuous republic was intrinsically attractive to him; the image of the Revolution, a clear revolt against authority, was not.

The crusade to control the habits of the masses was something Morse could wholeheartedly support. His notion that the world was divided between truly devout Christians and the ungodly multitude transferred easily to the political realm. Luxury, "this bewitching and ruinous flame," influenced every class of people "down to the housemaid, who, ridiculously ambitious, even aspires to vie with her mistress, in the richness and elegance of her dress." As for laws restricting luxuries, Morse felt there was no doubt about their necessity, only their practicality. He was certain that the people needed sumptuary laws; it was uncertain whether they would accept them. He suggested that the republic would benefit from laws prohibiting the use of wine and spirits; outlawing dinners of more than two courses (except on holy days) and forbidding the sale of "high priced buttons" and "balloon hats." The people could use the money they spent on these extravagances to pay both public and private debts. Most of these luxuries were symbols of foreign influence: "with foreign luxuries we import foreign vices."

Morse thought the situation was grave. Luxuries, he claimed, produced "effeminacy," "idleness" inevitably followed, and "idleness is ever followed with remorse, remorse with melancholy, and that with suicide." Morse saw the American Republic on the verge of ruin; two states seemed particularly endangered-Massachusetts and Rhode Island. Yet history offered hope; Sparta, Morse claimed, had been in similar straits but had been saved by a heavy dose of sumptuary laws. Because of these laws, Sparta avoided the revolution common in other Greek states. The Swiss, like the 
Spartans, also benefited from sumptuary laws; - because of such laws they were "perhaps the happiest people in the world."

Showing some of the combativeness that would become a permanent part of his personality, Morse addressed unspoken objections to sumptuary laws. He was especially annoyed that laws aimed at the people's frivolous habits had become "a wide field for the fancy of a wit to ramble in." For Morse, it was particularly important that the laws be framed in such a way that they would not be the target of satire and jest. He addressed what he saw as the most important unspoken criticism of sumptuary laws: the people were against them. Morse's response was to state frankly that "some would doubtless oppose them [the laws] — for those they are intended." He thus revealed his deep suspicion of the people, as well as a tendency toward elitism and antidemocratic positions. Given a choice between individual liberty and effective, even oppressive, government, Morse always chose effective government. For Morse, the very existence of opposition to a law was strong evidence that that law was needed.

We need not look too far for the source of his opinion: "If my opponent is to stamp impracticability on all laws that will meet with opposition from people, and will say that all which are impractical are impolite, and ought to be rejected, he must renounce the bible, for no laws are more opposed than those recorded in that sacred book; he must renounce too his friendship for all good government, and to appear an open advocate for complete anarchy." Again there was a clear parallel between Morse's religious and political views. Mankind, burdened by sin and moral blindness, had for centuries rejected the truths of Christianity; that they would reject equally salutary political truths came as no surprise. Just because sinners rejected a law was no reason not to impose it. This was true in both the secular and religious polity.

Morse's views expressed in the debate with Daggett were conventional for a young man from New England about to enter the ministry. The concern for the morality of the people, the notion that the people's habits would determine the future of the republic, and the demand for extensive government control of behavior were common themes in countless sermons by New England ministers in the 1780s. The establishment of free, republican institutions had spawned a deep concern about America's future. Morse believed, like many New Englanders, that Spartan virtue could and must sustain the Republic. As Morse traveled to the South and to other parts of the new Republic during the 1780s, he would find that his version of republicanism was not universal. As we shall see, Morse would make New England the model for the rest of the nation; New England, in 1785, had very nearly arrived, in Morse's mind, at a state of 
social, religious, and political perfection. He saw New England as a Christian Sparta whose example the rest of the Republic should follow. ${ }^{33}$

The Jedidiah Morse who defended sumptuary laws in the debate with Daggett hardly seemed like a young man in the midst of a moratorium, beset by identity problems. In the debate, he articulated widely shared positions with certainty and confidence. The role of moral guardian and shepherd seemed securely in place. But clearly this was not the case. Morse was, in the mid-1780s, caught between his role as cleric and his desire to be an author and produce geographies that would sway opinion and produce a profit. He refused to settle as a minister, turning down permanent positions in order to pursue his geographical research.

Rarely, during the 1780s, did Morse express his anxiety or his sense of indecision about his identity. The seemingly innocuous play written for his students was one expression of the concealed turmoil in the young Morse. A more important expression of this turmoil appeared in a letter written from New Haven to his father in March 1785:

I am a little low spirited to-day-I attribute it [to] the dullness of the weather-I know of nothing else particular which should occasion it-If you have ever been acquainted with melancholy, you know one of its distinguishing characteristics is to make us look upon the World and the affairs of it upon the wrong side-everything which, in our prosperous Moments, appears agreeable and promising - is then overspread with dismal gloom-which makes us recoil from it with horror-It is happy for us that it does not always last, it would render existence a burden and lead without doubt to frequent suicides-Yet at times these gloomy turns are of essential service to remind us of our Duty-and to show us the vanity of worldly enjoyments-for perhaps the world never appears in its true light, more strikingly than in our gloomy hours-In prosperity the world looks so alluring, that we are too apt to wish for an immortality hereindeed we are apt to expect it, if we may Judge from the general conduct of Mankind-Death is an irreconcilable Enemy to Prosperity-it is frequently but the reliever of Adversity - . . In Adversity the world looks gloomy and disagreeable - we can easily be reconciled to quit it, and prepare for a world of uninterrupted happiness-On the contrary when the world affords us delight and everything operates to our temporal advantage and pleasurewe quit it with the deepest reluctance-think it a cruel separation. All I wish for, and all I desire is that whether I am in Prosperity or adversity, cheerful or gloomy, rich or poor, beloved or despised I may have a truly benevolent, even, Christian temper and disposition—and that I might live like a true disciple of the blessed Jesus-There is nothing worth a farthing in this world but religion-I wish I could always think so-My 
honored Parent, I feel happy that I can thus freely communicate to you my whole soul - it affords me the most substantial satisfaction-I feel much better than when I first sat down to write-My letters I know are always communicated to my good Mother-I wish her always to receive them as coming to her, in part, tho addressed to you. My affection for you both is inexpressible by Words. In my conduct I will be careful to discover it $-{ }^{34}$

This private statement, written to his parents, contrasted sharply with the public utterance produced for the debate at Yale. The letter revealed an anxious and gloomy Jedidiah Morse caught between the allure of the world and prosperity and the dictates of Christian saintliness. The imagery suggested that money ("a farthing") was a fundamental yardstick, even of religion, that, even in the end, money and religion were somehow related. As prosperity and saintliness wrestled for Morse's soul, Death hung like an apparition over the conflict, driving Morse in the direction of a "Christian temper and disposition." Yet although this statement was revealing, it was not a confession. It began personally enough, but Morse quickly put distance between the issue and himself. What began as a description of his own "melancholy" subtly became a discourse on "the general conduct of Mankind." Even so, the outburst, in letter form, served its purpose; it gave Morse "the most substantial satisfaction" to write it, to express, however obliquely, his own turmoil. By bringing up the conflict between the world and religion himself and by dedicating himself to "live as a true disciple of the blessed Jesus," Morse also was fulfilling his parent's expectations. By expressing his gratitude to them and by ritualistically confessing and rededicating himself to saintliness, Morse carved a small but important area of autonomy and independence. He did not, however, resolve the issue; prosperity and the world of affairs continued to attract Morse, no matter how sincerely he rededicated himself to his duty and Christian holiness.

Too of ten we think of a son establishing his independence as a somewhat violent and vertical rebellion in which the son throws off the father and rises to manhood. In Morse's case, he achieved some measure of autonomy and independence by moving laterally and gradually. He never fully escaped the grip of his father; he managed, however, to develop some sense of autonomy by appearing to accept his father's values and the burden of the old man's expectations. By deciding on the ministry, and by almost ritualistic expressions of gratitude to his father, he slid sideways into a peculiar sense of control over his life. By acquiescing to such a degree to his father, and by becoming a minister of the word, in which his father so deeply believed, Morse groped his way to adulthood. Morse could 


\section{The Life OF Jedidiah Morse}

pledge his entire being to the cause of religion and still muse in a letternever-sent about studying mankind and the "SELF, the most profitable of all sciences." Indeed, by the mid-1780s another aspect of Morse had appeared. This side of Morse was curious about the world, about himself, and, to some degree, attracted to fame and wealth. For the rest of his life, he would be defined by the conflict between his commitment to religion, which called for self-effacement, and his desire to be famous and wealthy, which called for self-assertion. 


\section{3. \\ A Place in the World: Settlement}

In 1789, as the nation assembled its new government, Jedidiah Morse assembled the basic elements of his adult life. He published The American Geography, the book that made him America's leading geographer, the book that drew him into the business of making, promoting, and selling books. In the same year, he accepted the call from the First Church of Charlestown, one of the oldest pulpits in America. Finally, he married Elizabeth Breese and became a husband, and in time, a father. The moratorium between his graduation from Yale and adulthood came to an end with a rush. Jedidiah Morse agreed to play the four roles that ultimately defined his adult life: minister, writer, husband, and father. From 1789 to his death in 1826, these roles would, by turns, mesh and conflict. Morse never found a way to play all four comfortably, and, furthermore, his life was complicated by the lingering presence of a fifth role: he never fully escaped his father's influence-he became a father himself and a man of wide reputation, but he also remained a son.

During the second half of the 1780s, Morse tried, with some success, to blend his ministerial career with his desire to write geography. A desire to gain maturity as a preacher and to collect geographical information motivated his trip to Medway, Georgia, to temporarily take over the pulpit of former Yale classmate Abiel Holmes. The trip also brought him into contact with the world outside New England. On the journey to Georgia he stopped at Mount Vernon to visit George Washington. His visit deeply affected Morse; he saw Washington as more a shrine than a man. During their brief visit they discussed, and deplored, Shays's Rebellion, and Morse left thinking the Old General "the greatest Man alive." The South, in general, Morse found wanting. He concluded that its people were "widely different" from New Englanders: "I cannot but give the preference to my own Country."

Morse's brief stint in New York City also served his ministerial and writing careers. He apparently obtained the position through the influence of Ebenezer Hazard, who had become interested in Morse's labors as a geographer. An influential member of the Presbyterian church Morse served temporarily in 1788, Hazard invited Morse to fill the vacant pulpit and suggested that while in New York "you can pick up Material for your Geography." It was also Hazard who suggested that Morse delay publishing his geography until the Constitution was ratified. This would al- 
low Morse to print the Constitution in the book and take advantage of the public's interest in the new nation. Apparently, there was a chance that the position in New York could have been permanent, but, according to Hazard, the congregation found Morse too engrossed in his geography and too little interested in preaching. Indeed, Morse's experiences in Georgia and New York were not entirely happy ones; he left both positions under vaguely unhappy circumstances. His friend Samuel Beach suggested the "the unkind treatment" Morse had experienced in the South and in New York was "providential," because it led to his settlement in Charlestown, Massachusetts. ${ }^{2}$

It did, in fact, appear that Morse's settlement in Charlestown was a happy event. Unlike Georgia and New York, Charlestown was both close to his father and a prestigious pulpit. Again, as in New York, he was supported in Charlestown by an influential patron. Jeremy Belknap, a minister and historian like Hazard, was interested in Morse's progress as a geographer, and when the Charlestown pulpit fell vacant, Belknap recommended him to the congregation. Belknap was friendly with Richard Cary, a wealthy distiller, and influential member of the Charlestown church. After May 1788, when Morse came to Charlestown as a candidate, Cary wrote Belknap thanking him for suggesting Morse: "He [Morse] discovers the pious Christian, as well as the judicious divine. His amiable, prudent, benevolent temper will always command him affection \& esteem. He preacht upon the great doctrines of the Gospell in such clear, evangelical strains as to engage the closest attention \& admiration of the Congregation. . . . The people in this town are so fond of Mr. Morse they will, I doubt not, give him a unanimous call, which cant but be pleasing to him. His acceptance of it will greatly promote peace and harmony here, so essential to the prosperity of any people. I will venture to say, nothing will be wanting on their part to make his life easy and happy, according to their ability." ${ }^{3}$

Thus the connection was made with high hopes and good feelings, but Cary's letter hinted at difficulties in the town. The Charlestown that was to be Morse's home for three decades was, in many respects, divided in 1789 and destined to become more divided. Physically, the town seemed pleasant enough; Luigi Castiglioni, who visited Charlestown in 1787, found it "quite pretty to look upon." He was impressed by both the "handsome sward formed by lawns divided from each other by picket fences" and the view "from the top of Bunker Hill ... of the city of Boston and of a part of the mainland." Castiglioni saw a town recently rebuilt. In 1775, the British had burned it to the ground and the population had scattered to the countryside. Timothy Dwight thought the town ugly, and that "a miserable mass of prejudices" had prevented the people from properly rebuilding. Only a part of the original inhabitants had returned after the 
Revolution, and these were "mixed with strangers." Dwight thought "the inhabitants of Charlestown are not a little divided in their parochial, town and public concerns; and this division prevents much of the pleasure of life which might otherwise be found on so charming a spot."

The attractiveness of the town was open to debate, but Dwight's contention about the influx of "strangers" was accurate. In 1789 there were 1,579 people in Charlestown, and a large portion were recent arrivals. Between 1776 and 1778 only six newcomers had arrived, but the pace soon quickened. The big jump came between 1782 and 1789, when 425 newcomers settled in the town. By 1789 more than one-fourth of the population was recently settled, and many established families, who could trace their Charlestown roots back to the 1630s, had not returned. Evidently the town government thought the new people posed a threat to good order; in 1789, the town selectmen voted to compile a list "of Strangers" and have the town clerk "report their doings to the Selectmen."

While the buildings and many of the people were new, the town still had a deep sense of tradition. The pulpit of the Charlestown church was one of the very oldest and most revered in New England. The Puritan settlers of the Boston area were living in tents and huts when they signed the first covenant establishing the church. Great and saintly men had stood in the pulpit: John Harvard, Simon Bradstreet, and, for fifty years (1724-74), Hull Abbott. In 1741, George Whitefield had preached his evangelical message from the same pulpit and stirred the town to a peak of religious interest. Responding to Whitefield, sixty-six new members flocked to the church - the best year for new admissions in the eighteenth century. On the day Morse took over this historic church, the membership stood at 135-forty-three males and ninety-two females. The membership constituted approximately 9 percent of the town population, yet the town had, until 1803, control of the church. In fact, the town owned the church and paid normal expenses by selling pews to members who paid extraordinary costs by voluntary subscription. Although members bore the cost of the church, all legal voters had a right to vote in church affairs at the parish meeting. This arrangement worked well when everyone had similar religious views and paid deference to the established minister. After the Revolution, the growing heterogeneity of the town came into increasing conflict with the ideal of a single established church. ${ }^{6}$

Charlestown in 1789 was a metaphor for America after the Revolution. Deeply rooted and cherished ideals hung like smoke in the air, and people continued to operate according to those ideals. Residents still acted as if the town and the church were one, and they eyed newcomers suspiciously, assuming, for the moment at least, that they posed a threat to harmony. Yet as they attempted to live by old truths, they must have sensed that 
something fundamental had changed. Whenever they dug a cellar for a new house, they discovered the charred beams of the ancient homes that had once graced the town. The smell of scorched wood and the streets full of bustling strangers were clear signs that the Revolution had marked a turning point in their history. It had cost them their town; all the old physical landmarks had gone up in flames. More subtle, but ultimately more important, the Revolution had let loose forces that challenged many of the old social, moral, and spiritual landmarks. Jedidiah Morse came to this town deeply imbued with New England tradition, with a sense of the ministry as service to a tightly knit community. He expected deference and obedience; for the most part, he was disappointed.

Morse came to Charlestown not only as a minister but also as a geographer increasingly immersed in the book business. His success with Geography Made Easy (1784) had lured him into the field. Between 1784 and 1789 perhaps a majority of his time and energy was devoted to putting together a big geography that would capitalize on the growing interest Americans had in their newly independent country. Morse correctly saw the 1784 text as "a Juvenile essay" that "scarcely extended beyond the limits of my native state, Connecticut." To enlarge his vision he traveled to Georgia and mailed countless questionnaires to leading citizens in every part of the country. He read widely, absorbing the available literature that described America. He knew that he was building a book that could become a popular and useful text. He made sacrifices in order to write the book but was determined not to hurry the process, "even though," as he admitted to William Livingston, it "sometimes led to the borders of despair from pecuniary wants." His on-again, off-again salary as a temporary minister never kept up with his travel and mailing costs. ${ }^{7}$

The result of these labors was The American Geography. ${ }^{8}$ Written at a time of great political excitement, it became what Morse no doubt hoped it would - the most widely read description of the nation created by the passage of the Constitution. Yet it was vastly more than mere description; it was an appraisal of the nation taken in parts. The subtitle, $A$ View of the Present Situation of the United States of America, was a reflection of Morse's intent. Never a scholar, Morse wrote not a detailed geography text but a work that was, more accurately, an extended and complex jeremiad. It lamented the sins of the nation and exulted its virtues. It found virtue most common in New England and sin most common elsewhere.

The structure of the book was simple enough. After a brief introduction that gave a very general view of the universe and the Earth, Morse turned to the heart of the book, the description and appraisal of America. At the end he appended a very short section on the rest of the world. For example, the book devoted only two pages to France. The American sec- 
tion was divided in a significant way; the only region of the country that Morse saw as distinct was New England. For him, New England was "a country" or community with a history and character that crossed state lines. The rest of the nation lacked this cohesiveness and was dealt with on a state-by-state basis.

The New England of Morse's vision was a very nearly perfect community, "high, hilly, and in some parts of mountainous country, formed by nature to be inhabited by a hardy race of free, independent republicans." The women were "handsome" and were "taught to manage domestic concerns with neatness and economy." New Englanders amused themselves in healthy ways: dancing, sleighing, cricket, and foot racing. Only a corrupt few engaged in dueling, cock fighting, gouging, and horse racing. The English language was spoken with great purity and elegance. Politics was carried on by an elite of trained and dedicated men who were elected for "their Real abilities and a moral character unblemished." No one sought office: "The expression of a wish to be promoted, is the direct way to be disappointed." The existence of liberty in New England, and its maintenance, Morse attributed to the habit of dividing a father's estate equally among his children, excepting the eldest, who received a double portion. This habit preserved "a happy mediocrity," induced industry among the sons, and allowed for "no temptations to luxury." Finally, in New England learning was "more generally diffused among all ranks of people" than anywhere on the globe, and the people had "many good newspapers to keep them informed" ( $A G, 140-49)$.

This highly generalized vision of New England found its most perfect manifestation in Connecticut and its rural people. Morse claimed that his native state "resembles a well cultivated garden, which, with that degree of industry that is necessary to happiness, produces the necessaries and conveniences of life in great plenty." The people who created this garden "are almost entirely of English descent." The numerous and well-trained clergy "have hitherto preserved a kind of aristocratical balance in the very democratical government of the State; which has happily operated as a check upon the overbearing spirit of republicanism." Indeed, Morse believed that Connecticut religion was "the best in the World . . . for a republican government." He characterized church organization as both independent and federal. Each church had vast powers, but they were associated for "mutual benefit and convenience" ( $A G, 218-19)$.

This happy place produced, in Morse's mind, happy and healthy citizens. Its population had grown with amazing speed. This fact Morse attributed to several causes, the most fundamental of which was the dominance of "industrious, sagacious husbandmen." The image of the simple Connecticut farmer was vital to Morse's larger image of New England: 
Their farms furnish them with all the necessaries, most of the conveniences, and but few of the luxuries of life. They, of course, must be temperate ... and can subsist with as much independence as is consistent with happiness. The subsistence of the farmer is substantial, and does not depend on incidential circumstances, like that of most other professions. There is no necessity of serving an apprenticeship to the business, nor of a large stock of money to commence it to advantage. The ease with which a comfortable subsistence is obtained, induces the husbandmen to marry young. The cultivation of his farm makes him strong and healthful. He toils cheerfully through the day —eats the fruit of his labour with a gladsome heart-at night devoutly thanks his bounteous God for his daily blessings-retires to rest, and his sleep is sweet. $(A G, 240)$

This image becomes even more crucial because Morse was describing the rural Connecticut life that he had left when his father sent him to Yale. Morse's description contained within it a sense of yearning for a lost life. Lost not only to him, but also to thousands of other sons who could find no place on the dwindling farmland of Connecticut. Morse described a rural landscape, placid and populated by contented farmers but also "the nursery of men," sending thousands each year west and north seeking land and opportunity ( $A G, 144)$.

Morse was honest enough to admit that New England, and even Connecticut, were slightly flawed. He allowed that some New Englanders were too fond of lawsuits. "This litigious spirit" he knew well from the experience of his father. As justice of the peace in Windham County, Deacon Morse had settled countless disputes. When young Jedidiah heard that nearly twenty people were at his father's house clamoring to have their cases heard, he responded by calling the town "shameful, foolish, sinful" and by lamenting, "Oh Woodstock how art thou fallen!" This was no small matter; he wrote his father that the rash of lawsuits led him to believe that "the Spots of Desolution" had clearly appeared in Woodstock. This type of emotional reaction, however, never appeared in The American Geography. Morse tended to dismiss the "ligitious spirit" of New England as a temporary infection arising from the Revolution. ${ }^{\text {" }}$

Morse presented other complaints about New England (superstitious people, sharp trading, and presumptuousness) only to dismiss them as false or infecting only a tiny fraction of the people. However, he was more than willing to find substantial fault with the rest of the nation. At no point did he make general remarks about the southern or middle states as he had for New England. He obviously believed that neither section had established a uniform character that would warrant discussion. At certain points his general view of various sections did emerge. For example, in 
contrast to the Connecticut farmer, he described the country people of Maryland as having "a disconsolate wildness in their countenances, and an indolence and inactivity in their whole behavior, which are evidently the effects of solitude and slavery. As negroes perform all the manual labour, their masters are left to saunter away life in sloth, and too often in ignorance." This observation, Morse suggested, should apply not only to Maryland but "to all the Southern states" ( $A G, 352)$.

Everywhere that Morse found slavery and warm weather, he found a culture he did not like. Georgians, for example, suffered from "the long continuance of warm weather" which produces "a general relaxation of the nervous system." The warm weather in combination with slave labor resulted in "indolence," which, "especially among a luxurious people, is ever the parent of disease" $(A G, 445)$. Slavery, by itself, Morse saw as "the bane of industry." A free man was prodded by necessity and the possibility of gain, and thus will work hard; a slave denied opportunity will labor only if compelled. Morse did not attribute innate laziness to negroes or to any group; he assumed all men needed compulsion. His theory of work was, in short: "Industry is the offspring of necessity rather than choice. Slavery precludes this necessity; and indolence, which strikes at the root of all social and political happiness, is the unhappy consequence" $(A G, 65)$.

For Morse the sure sign of a flawed society was the existence of sinful diversions. He believed that time "not employed in study or useful labour ... is generally spent in hurtful or innocent exercise." The Virginia gentleman, Morse allowed, had a reputation for worthy literary and political endeavors, but this reputation was undeserved. Constructive diversions and social service too often take second place "to a spirit of gaming and barbarous sports." For Morse's taste, there were too many billiard tables, card games, and backgammon boards in Virginia. These evil things were too often found in taverns and public houses, where "the gambling gentry ... resort to kill time, which hangs heavily upon them." Unlike New England, where time was thought of as a vessel to be filled with useful labor and diversions, Virginia gloried in wasting it. Morse was particularly appalled by indications that children of the gentry were taught to mimic their dissipated and wasteful elders ( $A G, 390)$.

Morse painted a similar portrait of North Carolina. "Temperance and industry," he declared, "are not to be reckoned among the virtues of the North Carolinians." Like Virginians, they were fond of wasting time "drinking, idling and gambling," and this left them little time to improve their farms or their minds. North Carolinians were not only idle and dissipated, they were often violent and destitute of even the most fundamental aspects of civilization. Morse argued that "in a country that pretends to any degree of civilization, one hardly expects to find a prevailing custom of putting 
out the eyes of each other." Yet this was exactly what North Carolinians did. Morse described the custom: "The delicate and entertaining diversion, with propriety called gouging is thus performed. When two boxers are worried with fighting and bruising each other, they come, as it is called, to close quarters, and each endeavors to twist his forefingers in the ear-locks of his antagonist. When these are fast clinched, the thumbs are extended each way to the nose, and the eyes gently turned out of their sockets. The victor for his expertness, receives shouts of applause from the sportive throng, while his poor, eyeless antagonist is laughed at for his misfortune" $(A G, 418)$.

The Sabbath, honored as a day of rest in New England, was celebrated badly in the South. Morse claimed that "most civilized countries" regarded Sunday as "holy time." Not so in South Carolina and other parts of the South. Generally, it was ignored, or celebrated "by the convivial visitings of the white inhabitants, and the noisy diversions of the negroes" $(A G, 433)$.

Morse very rarely blamed the faults of Southern society directly on the negroes. He was, however, uncomfortable with the close association of the races in the South. The habit of having "Negro wenches" nurse white children particularly shocked him. The image of white babies nursing at black breasts made Morse shudder. This close association between black nursemaids and white children allowed the white youths to "imbibe their [negroes] low ideas, and vitiated manners and morals; and contract a negroish kind of accent and dialect." Morse, like many northerners, viewed "the criminal [sexual] intercourse between the whites and blacks" with repugnance. The image of illegitimate mulatto children serving as slaves to their fathers shocked Morse. Given all his negative feelings about slavery and its influence, Morse was remarkably short of solutions. He hoped for a general emancipation, but could not bring himself to visualize and accept a society in which free blacks lived with whites. He never fully embraced colonization, but he was clearly inclined toward that solution to slavery ( $A G, 67-68)$.

Thus, the primary theme of The American Geography was a running comparison between New England and the rest of the nation. An idealized vision of New England stood as a yardstick with which to measure the other sections. As Morse described each state, the comparison evolved like the finish on a piece of furniture. It may be hard to perceive, but it is most certainly there. Morse favored his own section because he was somewhat provincial and possessed the normal predilection for the culture that nurtured him. Although Morse's preference for New England was generally unconscious and seemingly an automatic response to different cultures, it did have two conscious and dominating themes. New England culture was superior because its population was imbued with the spirit of enterprise, and these enterprising New Englanders were superior because they were ethnically homogeneous. 
Because New England was never dominated by a slave labor system and estates were divided among the sons, Morse felt enterprise arose as a crucial trait in the New England character. New England's traditional commitment to education was the final ingredient in the mix; armed with education and prodded by necessity, New Englanders had become creative and inventive. He was willing to admit, however, that "Carolinians sooner arrive at maturity, both in their bodies and minds than the natives of colder climates" and that they "possess a natural quickness and vivacity of genius superior to the inhabitants of the north." Although he often granted Southerners this measure of superiority, he argued that they "generally want that enterprize and perseverance which are necessary for the highest attainments in arts and sciences. They have, indeed, few motives to enterprize."

This view Morse also applied to people outside the South. The Dutch, whom he discussed in several places, were "neat and industrious," but they have "very little enterprize, and seldom adopt any new improvements in husbandry." This he explained as a product of their "habits and want of education to expand and liberalize their minds." Morse believed that New York was half a century behind New England and attributed this status to "want of enterprize in her inhabitants" $(A G, 261)$.

"Enterprize," however, did not mean simply a desire for material wealth and profits. Morse was of ten critical of the mere pursuit of money. The citizens of Maryland, for example, were bent on "nothing but the pursuit of wealth" and were, therefore, "unsocial, unimproved and unhospitable." $\mathrm{He}$ claimed that Albany, New York, was "an unsociable place" largely because the people were "so eager in pursuit of gain." Often the southerners whom he criticized for killing time at evil diversions were, oddly, also seen as lusting after gain. He was capable of portraying southern culture as both too social because of their love of taverns and public houses, and unsocial because of their pursuit of wealth. The New Englander, by contrast, was enterprising and sociable while rejecting materialism and the unseemly pursuit of profit that led to conflict and "rivalship" ( $A G, 258,353-54)$.

Morse never explicitly defined the word enterprise, but its meaning was crucial to understanding The American Geography and Morse himself. An enterprising person or culture was apparently one bent on improvement, dedicated to finding new and better ways of doing things while rejecting the wealth and luxury that often came with profitable new methods. Throughout the text, Morse applauded new inventions that had come to his attention. He was a keen advocate of new machinery and processes to lighten man's labor. He found Connecticut a most inventive state, full of enterprising people. Writing like a civic booster, Morse praised "Mr. Chittendon's useful machine for bending and cutting card teeth," a new process for extracting oil from sunflower seeds, David Bushnel's subma- 
rine the American Turtle, Mr. Hanks' "method of winding up clocks by means of Air or Wind only," and on and on. His praise was for the usefulness of these inventions, not for their profitability: "Machines ingenuously constructed will give us immense assistance." Such inventions also increased American independence; the process whereby sunflower oil is extracted, for example, was valuable because it could reduce American dependence on foreign olive oil. Indeed, Morse was an early supporter of manufacturing because it reduced the nation's dependence on foreign goods, which too often were "showy trinkets." Thus, manufacturing, as a manifestation of enterprise, did not seek profit but, rather, escape from dependence and a dangerous reliance on foreign suppliers $(A G, 216,88)$.

The word enterprise takes us close to the center of Morse's value system. He valued hard work and inventiveness because it reduced the threat of dependence and made the community more self-sufficient. Morse, in effect, painted a moral vision in The American Geography, dominated by the enterprising New Englander who was ambitious and inventive, who reaped the profits of his labor, but who rejected the luxuries and diversions that follow. This New Englander should be the model for all Americans; eventually the entire nation should become like Morse's Connecticut yeomen and inventors. If they were not seeking profit and material improvement, what was "enterprize" after? Morse dimly perceived a collective goal in what he referred to as the "American Empire." Morse saw the western movement of "American habits" as a dramatic chapter in human history. Describing the future of the western territories, Morse declared:

It is well known that empire has been travelling from east to west. Probably her last and broadest seat will be America. Here the sciences and arts of civilized life are to receive their highest improvement. Here civil and religious liberty are to flourish, unchecked by the cruel hand of civil or ecclesiastical tyranny. Here Genius, widened by all the improvements of former ages, is to be exerted in humanizing mankind-in expanding and enriching their minds with religious and philosophical knowledge, and in planning and executing a form of government, which shall involve all the excellencies of former governments, with as few of their defects as is consistent with the imperfection of human affairs. . . Elevated with these prospects, which are not merely the visions of fancy, we cannot but anticipate the period, as not far distant, when the AMERICAN EMPIRE will comprehend millions of souls, west of the Mississippi... . The God of nature never intended that some of the best part of his earth should be inhabited by the subjects of a monarch, 4000 miles from them ... the power of European potentates will be confined to Europe, and their present American dominions will become, like the United States, free, sovereign and independent empires. $(A G, 469)$. 
Herein lay the true meaning of enterprise. Americans were called to action not to serve their own selfish ends, not to kill time, but to fulfill their providential role in history. Enterprise should produce a material, political, social, and religious utopia. Ultimately an American's life was not his own, it belonged to Providence, which decreed America and Americans to be the scene and the main players in the next great improvement in human affairs. This notion was as old as New England; for more than a century and a half, ministers such as Morse had been calling their listeners away from their selfishness, condemning them for their faults, and reminding them of their crucial role in God's plan for the world. Morse, a geographer and a minister, was merely continuing and expanding the literary form-the jeremiad-that these calls had always taken. Looked at in this way, a book that appeared to be a crabby and provincial vision of America became a modified sermon lamenting American sins and calling the faithful back to a higher purpose.

This jeremiad, however, has a dark and peculiarly ethnocentric element. The population of the United States, according to Morse, "is composed of people of all most all nations, languages, characters and religions." Yet, he claimed, correctly, that most "are descended from the English," and only to these people did he give a special name: "Anglo-Americans." This created a central contrast between New England, settled exclusively by the English, and the rest of the nation, saddled with a mixed population. Morse defended the entire population from the slurs of Buffon and Abbé Raynal, who contended that New World people were inevitably inferior to Europeans. At the same time, Morse belittled those areas of America that were not exclusively English. For example, the citizens of Baltimore were "unsocial, unimproved and inhospital" because "the bulk of the inhabitants, [are] recently collected from almost all quarters of the worldbent on the pursuit of wealth, varying in their habits, their manners and their religions, if they have any." In North Carolina, the love of sinful diversions Morse attributed to a population made up of "a mixture of inhabitants" and the influence of slavery. He disliked Albany, in part, because it was "a hetergeneous collection of people." In areas where such a mixed population existed, Morse habitually asserted that no generalizations about the state's character could be made. He assumed that a community existed in New England based on common English roots, religion, and habits and that the rest of the nation was not a community, except in the simplest sense of the word ( $A G, 63-64,353,258)$.

Morse assumed that inevitably all of America must become like New England. He stated that "the Anglo-Americans" share the land with numerous other peoples, "who retain . . . their native language, in which they perform their public worship, converse and transact their business." $\mathrm{He}$ was painfully aware that the population included black slaves, who 
shared so little with Anglo-Americans. Yet Morse anticipated a time "when all distinctions between master and slave shall be abolished; and when the language, manners, customs, political and religious sentiments of the mixed mass of people who inhabit the United States, shall have become so assimilated, as that nominal distinctions shall be lost in the general and honourable name of AMERICANS." Because the coexistence of former slaves with their masters would be "disagreeable and unnatural," Morse would colonize them, remove them from the culture. As for the remaining non-Anglo-Americans, Morse merely assumed that they would slowly take on the habits and character of New England. Eventually, all of the United States would become like Connecticut. Until that day, Morse could not bring himself to call the population of the United States Americans; he fell back on the awkward term "Fedro-Americans" (AG, 67-69).

New England standards and values would control the Americanization of foreign elements. The English language, which was "spoken with great purity, and pronounced with propriety in New England by persons of education," would eventually dominate in those areas where "they have had a great influx of foreigners" and "the language in many instances is corrupted" $(A G, 67)$. New territories as they fall under American control will be most deeply influenced by New Englanders. Morse found no cause for grief in the rapid growth of New England's population; the excess would be diverted first to the settlement of the West and second to the developing manufacturing sector of the economy. The settlement of Vermont served as a model for the expansion of America: "The bulk of the inhabitants are emigrants from Connecticut and Massachusetts. . . There is one settlement of Scotch people, which are almost the only foreigners in the state. As to character, the manners, the customs, the laws, the policy and the religion of the people in Vermont, it is sufficient to say they are New Englandmen" $(A G, 28)$.

Throughout the text, Morse implicitly conveyed the notion that the New England Way was to be the American Way. If America was to be a republic, then, Morse suggested, the nation should look to Connecticut as a model. Morse's home state "has ever been a republic, and perhaps as perfect and happy a republic as has ever existed." The Revolution, which "deeply affected the government of most of the colonies, produced no very perceptible alteration in the government of Connecticut." The other states, which were more "monarchical in their government and manners," would have to make substantial changes in their political system in order to become true republics. Most of the nation outside New England would confront the difficult task of exchanging "their monarchial for republican manners" while Connecticut would continue "in her old track, both as to government and manners" ( $A G, 241)$. 
This presentation of Connecticut as a model goes to the very heart of The American Geography. Connecticut was ethnically pure, peopled by an enterprising and inventive sort, and governed by truly republican principles. Outside New England, Morse found a mixed mass of people who possessed no definite character-no sense of community. Particularly in the South, the population, corrupted by slavery and a warm climate, lacked enterprise and virtue. They idled away precious time in taverns and unprofitable diversions, when they were not engaged in criminal intercourse with their helpless slaves. At the same time, Morse envisioned that America would become the seat of the most perfect community mankind had yet seen. This was a disquieting reality for Morse and many other New Englanders in 1789. They had long considered themselves a separate country, with a unique covenant with God. The Constitution had bound them together with a vast population of strangers. Could New England's covenant with God be extended to include all these new elements?

Morse's answer was ambiguous but essentially hopeful and optimistic. Like the jeremiads of the seventeenth century, Morse's geography called for repentance and rededication. He called for an end to slavery (without being definite on method) and a turning away from intemperance and corrupt paper money schemes and countless other faults. Like the jeremiads of old, he held up a model for emulation, but unlike a seventeenth-century divine he pointed not to the past, but to the present-day New England. To this degree his vision was hopeful. The Constitution could be a rallying point, and the rest of the new nation would respond to New England's shining example. Yet there were tensions in the vision. The New England community was the product of a unique history and of ethnic homogeneity. At times, Morse implied that New England was the happy and unique product of a great race of people (Englishmen) brought together by Providence with the right climate. Thus, New England was unique; its character and manners could not take root in other areas. There was also the unresolved and unarticulated tension between Morse's paean to Connecticut yeomen who rejected the market and progress and the market-oriented entrepreneur who altered the very face of the landscape with his inventions. In the final analysis, Morse's vision of the future was uncertain; the Revolution and the Constitution had posed a question: Could America become New England?

On a much more practical level, The American Geography posed an important personal question for Morse. Was he a writer or a minister? Congregational ministers of ten supplemented their salaries by engaging in outside activities, but Morse clearly overdid it. Until 1819, when he left the Charlestown pulpit, his ministerial duties and his writing persistently clashed. Af ter publishing The American Geography in 1789, Morse received 
some criticism, but the response was generally good. He had timed the appearance of his book well; for three decades the name Morse and geography would go hand in hand. For good or ill, Morse had entered the book business.

Publishing was undergoing a fundamental revolution, the simplest aspect of which was the transition from scarcity to abundance. Books and newspapers were scarce in Woodstock in the 1760s and 1770s, but toward the end of the century, Woodstock, like all other villages, experienced a dramatic rise in the amount of print available. Technology and the aggressive marketing of books created a flood of print that washed over even the most isolated village. Before 1750, the average family, if it had books in the home, possessed a few standard "steady sellers": a Bible, a book of sermons or a religious songbook, and almanacs. They read these works again and again, often out loud. Newspapers were rare outside the seaboard towns, making their way to village taverns and inns long after publication.

Although modest technological advances, especially in paper production, and more aggressive marketing fueled this print revolution, changes in American political and social life were also important. The Great Awakening and the American Revolution undercut the consensus that underlay the village hierarchy. People were eager to read about new ways to get on the road to salvation or to read about new methods for organizing government. Especially after the Revolution, Americans of all kinds felt a need to consume useful knowledge to keep up with the times and to learn about the new nation created by the revolt against England. The need for information of all kinds grew rapidly, and commerce stepped up to satisfy the need. Jedidiah Morse's geographies were an important part of this commercial explosion. They quickly gained a reputation as standard and useful. In his Farmers Almanac for 1793, Robert B. Thomas advised New England farmers to spend long winter evenings reading "useful books." $\mathrm{He}$ especially urged them to buy Ramsay's History of the American Revolution, Belknap's History of New Hampshire and Morse's Geography. It is ironic that Jedidiah Morse, who sought to defend the traditional structure of the New England village and to shore up the declining authority of village clerics, was an important element in a commercial revolution that employed books and newspapers from the "outside" to erode that authority.

This revolution began slowly. It did not completely modernize the business of printing and publishing until the middle of the nineteenth century. In Morse's time, it remained an extraordinarily fragmented and decentralized development. The role of author, for example, was exceedingly vague. Most works were the products of people, usually gentlemen, who wrote to advance knowledge and to contribute to the public debate on politics, science, and religion. They were either independently wealthy 
or earned their living in the countinghouse, the courtroom, or the church. There were no large publishers willing to risk capital on the publication of books. Getting a book printed and distributed often meant dealing with a number of local printers who doubled as distribution agents. An author who wished to profit from his work was forced into a vexing world of contracts, distribution agreements, and printer-pirates more than willing to steal an author's work. ${ }^{10}$

Indeed, Morse became immersed in the world of printing, distributing, and financing his publications. His correspondence from 1789 until his death in 1826 was very much the correspondence of a minister and a businessman. No exact portrait of his business life is possible, yet several things are clear. He did not always sell the copyright for his books outright and let a professional bookseller handle the countless details. Morse printed the books himself and sold directly to retailers from whom he collected a royalty on books sold. His deal with Thomas Green of New London, Connecticut, was typical. Morse sent Green books on trial; if they did not sell, Green apparently had the option of sending them back. Morse received nine shillings for each of these books sold. Green also took some books at his own risk and paid Morse a royalty of eight shillings. $\mathrm{He}$ charged Morse a small sum for advertising that was subtracted from sales. In 1794, Morse wrote a German correspondent that he had sold 20,600 copies of The American Geography. Thus, at eight and half shillings per book, Morse took in very nearly nine thousand pounds on that book alone. In addition, his geography text for schools continued to sell well. Even if we disregard the sales of the school text and assume that Morse's cost per book was four shillings, that would make his income from writing between 1789 and 1794 approximately fifteen thousand dollars. His salary from the church was eleven dollars per week plus a house and wood for heat. By 1794 , the income from his geography amounted to approximately five times his minister's salary. ${ }^{11}$

This money, however, did not come without a measure of anxiety. His friends knew that his writing distracted Morse from his ministerial duties. In 1789, his college roommate and ministerial colleague, Abiel Holmes, wrote: "To say truth, I have all along been afraid this very thing [writing] would prove a thorn in your flesh. I long to have you done with it, for your sake, for the sake of the public \& especially for the sake of the Church of Christ. ... It seems especially incumbent on you to get as free from this and every other secular embarrassment as you can." 12

The most insistent pressure came from his father. In 1792, the deacon wrote, "My Son-have you not need to be admonished-May I not ask when there will be an end of your making Books." He reminded his son "not to forget that which is the conclusion of the whole matter, to fear 
God and keep his Commandments." The son responded that he hoped "I am in the way of my duty and that my great aim is to promote the cause of my Redeemer." Indeed, Morse's writing career was a common theme in the correspondence between father and son in the early 1790s. Morse attempted to assure his father that he had not strayed from the path of virtue. He promised not to spend too much time on his geographies, but he admitted, "I must confess I have a greater itch for publishing books now than I ever had." He argued that his writings served his country, and that "my Geography is well spoken of by the candid and judicious." He finally begged his father "to let me go on without anxiety-I hope I shall not injure my health." He claimed that "my mind after being engaged in Geographical pursuits returns with ease and pleasure to my Theological studies."

Morse was grappling with the simplest of realities. Personal identity was, in part, the product of expectations that arose from family, friends, and community. As a minister, Morse inherited a particularly insistent set of expectations. He was God's agent, devoted to the cause of Christ, dedicated to promoting true religion and virtuous behavior. This was a sacred office to which one dedicated one's whole life. His friend, Holmes, his father, and his congregation expected nothing less than complete devotion to the role of minister. Devotion to other goals, given these community and family expectations, was clearly inappropriate. Morse's "itch" to make books conflicted with the moral injunctions of his father and his community. He would rationalize and attempt to evade the power of these injunctions, but he could not proceed with his writing career free of anxiety.

Morse persisted in his writing career until his death. He rationalized his behavior to his father and to his congregation, and on he wrote. In some measure it was a son's rebellion against his father-a loving, but dominating father. Morse's dedication to writing, however, has other, more complicated roots. In the eighteenth century, the office of minister was local. The town was the focus of the minister's life; he saw the townspeople as his flock. He stood together with local officials as the embodiment of law. A minister's self-esteem came from his perception of success on this local level. Were his people "united in" him? Were they peaceable, God-fearing people? Did the church flourish? By 1789, this definition of the New England town minister was beginning to unravel, to become increasingly anachronistic. Morse's memories of Woodstock could never have supported this definition. The history of religion in Woodstock was a history replete with contention and fragmentation. Woodstock may have paid lip service to the idea of a highly respected minister who stood with the magistracy as the pillars of social control, but the reality was different. All in all, Morse's childhood memories could not support the idea that a minister could expect to derive self-esteem and personal satis- 
faction from an office that was characterized by so much controversy and disharmony. ${ }^{14}$

The story of Abiel Leonard, Morse's childhood minister, offers a slightly different view on the situation. Certainly his church loved and respected him. Yet he sought satisfaction and fame outside Woodstock. Given the choice between serving his church and serving the nation in the Revolution, Leonard eagerly chose the national stage. His suicide may well have involved the conflict between local and national loyalties - we shall never know. In reality, Leonard tried to balance his local responsibilities and his desire to participate in much more exciting and promising national events. This was exactly what Morse tried to do his whole life. He tried to play two increasingly incompatible roles. He ministered to a diverse and contentious flock in Charlestown while seeking to play a role in larger events, and, most persistently, he wrote geographies that served as jeremiads for the benefit of the nation, not the town. Morse rationalized his geographical labors as service to his country. As early as 1785 , he wrote his father that "my own country merits my first and greatest attention and as the Geography of it has hitherto been very incomplete, as well as inaccurate, I am disposed ... to remove these inconveniences." ${ }^{15}$

Morse's "settlement" into a career as a geographer was, therefore, not only the product of self-interest and desire for profit but also a reflection of changing historical circumstances. Young men, like Morse, detached from family and the traditions of New England localism quite reasonably turned to the national stage as a place to give vent to their ambitions. Yet clearly, Morse never fully extricated himself from the influence of New England localism and provincialism. As his geographies illustrate, he idealized New England and served it up as a model for the rest of the nation. It was, however, not the New England town that Morse saw as a national model, but the New England character. Nowhere in his geography does Morse praise the town; he does, however, praise New Englanders' enterprise and ethnic homogeneity. The New England town did not translate easily to the national scene, but the New England character did. Aware that, like Woodstock and Charlestown, the image of the cohesive and harmonious town was a thing of the past, Morse praised a generalized character and set of habits that may have taken root in the seventeenth-century New England town but that, over time, had become the personality of the region.

In this context, his praise of enterprise was particularly significant. New England has always had a peculiar relationship with enterprise and the change it brings. Richard Bushman has identified a "Yankee spirit" that was securely in place in Connecticut by 1765 . People possessing this spirit were defensively independent; a bit greedy, but their cupidity was 
tempered by a regard for the public welfare and they believed in, or sought to believe in, the idea that God's plan for mankind was ultimately benevolent and rational. Morse was certainly one of these Yankees; for one thing, he fought a long inconclusive battle with his father in order to secure some measure of independence and autonomy. He labored long at his writing and publishing, both for the money and for the public good. Finally, his religious sentiments were notably devoid of cosmic, irrational piety; there was a sense that religious belief was a matter of hardheaded rationality. Like the New England he praised in his geography, he was the very personification of enterprise. Cut off from the family and town of his birth, he made his way by self-assertion and personal effort. Unlike his brother Jonathan, the family provided Jedidiah no established position in the town, and he had to make his way by enterprise. Jedidiah could develop no sense of self-esteem and worth from occupying a position in the town hierarchy; in essence, he had to find it himself - that required enterprise. ${ }^{16}$

If New England and Morse valued enterprise, they also valued stability and a sense of order. Although New England honored self-interest, it sought to control it. Successful enterprise brought profit, profit led to luxury, and luxury led to corruption. One way to check this process was to insist that the successful entrepreneur labor for the public good. The successful Yankee was expected to be philanthropic and engage in public service once his enterprise had secured him a high position in the community. His ambition and inventiveness disrupted the status quo, but his charity and service restored it. Change and improvement could go hand and hand with stability and order. Central to this vision was the hierarchical model of society. Enterprise and energy could take a lad from a middling Connecticut farm to Yale; he could study hard, but he would have to wear worn-out pants and frayed shirts. The young man could go into a profession; he could find a public need, fill it, make money and ascend the hierarchy to a position of eminence and respect. From that position, he could defend order and the hierarchy that he just climbed. Not surprisingly, the lad would feel considerable homesickness, which would express itself as a reverence for the past. While venturing out from town and family, he would urge deference to the habits and customs of the fathers as a scared obligation. One could change the future with enterprise while maintaining the past as a standard. In the 1790s, Jedidiah Morse found out that this was going to be virtually impossible. Enterprise, and its companion, equality, were more corrosive to the past than he imagined.

The third element of Morse's settlement in 1789 was his marriage. When he accepted the call to the Charlestown pulpit, the town had expected a bachelor preacher. No doubt, the single women of Charlestown were looking forward to the coming of this educated, refined, and eligible 
young man. The town had promised Morse a house when he married and perhaps hoped they would never have to fulfill the pledge. Both the town and its young ladies were disappointed. While preaching in New York, Morse had met Elizabeth Breese at the home of her uncle and Morse's patron, Ebenezer Hazard. She was the daughter of a distinguished family. Her father, Samuel Breese, was a respected judge, and her mother was the granddaughter of the Reverend Samuel Finley, the president of the College of New Jersey.

Morse courted Elizabeth during the latter half of 1788 while he was preparing the geography for the press. In January 1789, in a letter full of news about his book, Morse asked his father for permission to marry. In another letter, a week later, he described Elizabeth as being "of a respectable family_pious - genteel and agreeable and I think calculated to render me happy." ${ }^{17}$ Just before going to Charlestown in April, they were married. Their life together was, in many ways, full of anxiety and grief. Too many of their children died too young. Her husband was always involved in one battle or another, and often these fights intruded into the home. Their relationship, and the family they created in the Charlestown parsonage, serves as the subject for a later chapter. For the moment, a look at the burial monument erected by their sons in their parents' memory reveals a great deal. For the father, the sons listed his many accomplishments-minister, geographer, and "efficient promoter of great and wise plans for the public good." In contrast, Elizabeth Ann Morse was described as the daughter of Samuel Breese and the granddaughter of Samuel Finley. Born in New York City in 1766, she died in New Haven in 1828. She was "eminent for all the virtues that adorn the Christian wife and mother."

Thus, the spring of 1789 was a crucial time for Jedidiah Morse. His book was done, he married, and on April 30, at exactly the same time George Washington was sworn in as president, he was ordained the minister of Charlestown's ancient church. The basic elements of his life clicked together so easily that Morse was dizzy with optimism. His church, his family, and career as geographer looked like wide and easy paths laid out before him. He would follow each path with the grim and unrelenting determination of a man pursuing his duty. 


\section{4. \\ A Period of Singular Revolutions}

In March 1823, Morse apparently began what was to be an autobiography. As he gave over his "worldly affairs" to "the best of children," he began to mull over the thirty years he had spent as a pastor in Charlestown, years marked by bloody wars and the rise and spread of an "Atheistical Species of infidelity" that was overthrown by Christianity only to have "an infidel Christianity" rise in its place. The period also was marked by "political and religious divisions which generated Angry contention, affecting in a greater or less degree all the social relations of life." In this world of convulsions and social fragmentation, Morse played out his ministry and, as he admitted, it was "a station ... of peculiar exposure." This confusing world was, however, only one of the two that Morse inhabited. He also inhabited a world that was never quite real: a world of myths and unrealized ideals, the world of New England past. ${ }^{1}$

In what was probably Morse's first important public appearance as Charlestown's new minister, he delivered the funeral sermon for a wealthy and distinguished member of his church, Richard Cary. The sermon was traditional-even common-but it put an odd emphasis on "watchfulness." Morse defined watchfulness as the fundamental duty of all true Christians, whom he saw as "surrounded with numerous and powerful enemies." Human happiness became a function of vigilance; the world was a snare, the heart a deceitful source of lusts and passions. To be vigilant was "to put ourselves in the best possible posture of defense ... we wrestle not against flesh and blood, but against principalities, against powers, against the rulers of the darkness of this world, against spiritual wickedness in high places." This sermon suggests that Morse entered the 1790s fully equipped to become a suspicious, fearful believer and purveyor of conspiracy theories. Suspicion was deeply ingrained in his Christian republicanism, and political and religious life in the United States and the world between 1789 and the early nineteenth century provided a broad field for those suspicions. ${ }^{2}$

Indeed, the 1790s proved to be something of a landmark in the history of American suspicion, fearfulness, and even outright paranoia. Since the 1790s much of "official American culture" has been based on fear. Americans have feared France, Europe, the Negro, popular passions, fragmentation, and rising godlessness. For some there was an overriding fear of solipsism or nothingness, a fear that knowledge of self or the world was 
impossible. Any passion elicited fear, probably reflecting an unacknowledged dread of sexual passion. As Henry May has concluded, "What the defenders of rational culture were finally most afraid of was themselves." As Morse urged his listeners to be watchful and to fear the evil that pervaded the times, Morse was also anxious and fearful about his own virtue and worth. ${ }^{3}$

The 1790s were not good years for peaceful and honest introspection. Men like Morse could find so many external enemies (France, Jeffersonians, religious liberals) that meditation on one's own identity had to be put off to a later day, or forever. Why did there seem to be so many enemies, so many threats to virtue? The answer lies in the gap between behavior and rhetoric that characterized postrevolutionary America. Americans had employed the rhetoric of republicanism to rationalize their revolt against Britain. The emphasis on self-sacrifice, virtue, and communalism had allowed Americans to see themselves as the simple, innocent victims of British corruption and tyranny. Envisioning themselves as exempted from the commercial revolution that had debauched Britain, Americans clung to a myth of themselves that featured simplicity, communalism, and a rejection of individual ambition. Morse's Geography helped establish this complicated myth. Yet although Americans employed versions of classical republican thought as a national ideology, they behaved increasingly like modern liberal individualists. By 1790, the social and economic basis for republicanism was quickly dissolving. America, and Jedidiah Morse with it, was rapidly becoming a sprawling, speculating, capitalist society. This gap between self-perception and reality spawned fears of degeneration. The image of what America should be clashed so often with what the country clearly was that men like Morse could only conclude that evil conspirators were abroad in the land. For Morse, who believed that America was to be the Christian republic, every deviation from the spartan, republican path literally challenged the cosmic order. The 1790 s provided deviations in rare abundance; so many deviations that Morse called the age "a period of singular Revolutions." ${ }^{4}$

After settling in Charlestown, Morse soon discovered that he lived among many who deviated from what he considered true religion. A moderate Calvinist, Morse preached that salvation required faith, that man was innately corrupt, that not all would be saved, and above all, that Jesus was divine. In the Boston area during the 1790s, Morse found many who held different views. For thirty years Morse would defend his orthodox views against those he called "liberals," "Arminians," and, later, "Unitarians."

Jedidiah Morse's defense of orthodox Calvinism and his attacks on religious liberals were central themes in his life in Charlestown. He did not create the conflict; it had been an important debate in American religious 
life since the middle of the eighteenth century. The central doctrinal tenet of the liberal movement that would ultimately become Unitarianism was an attack on Reformed notions of God and man and their relationship. Liberals sought to redefine God as a benevolent and loving father who welcomed into Heaven all who would exhibit real belief and act as true Christians. Liberals saw mankind as innocent and sinless; given this starting point there was no reason to arbitrarily condemn some to eternal damnation. Some liberals also cautiously moved away from orthodox views of the Trinity. Some, a very few, went so far as to challenge Christ's divinity. Morse's liberal opponents also challenged the dominance of religious creeds, sought wider religious freedom, and insisted on the independence of congregations. Although they did not challenge the privileges that came with legal, tax-supported establishment, liberals fought most orthodox movements to standardize the way churches admitted members and tested ministers on matters of doctrine.

This highly generalized liberal religious outlook flourished in the seaport towns of New England. Politically, these areas were overwhelmingly Federalist and hostile territory for Jeffersonians and French ideas. Morse therefore of ten found himself in complete sympathy politically with men whose religious ideas he deplored. Religious liberalism never really had its headquarters anywhere; but, over the last half of the eighteenth century, Harvard tended to be the center of liberal religious thinking, whereas Yale, especially under Timothy Dwight's control, was the intellectual center of orthodox thought. As a Yale man, with his roots in the conservative soil of Connecticut, Morse was clearly within the borders of the enemy camp when he took over the Charlestown pulpit. ${ }^{5}$

Thus it was not surprising that by Christmas 1789, Morse was embroiled in religious controversy. He wrote his father that he had received a letter, signed "A Layman," that defended the unity of God and denied the divinity of Jesus. In response, he was writing "a defense of the Divinity of the Savior." Spurred by the letter, Morse also delivered a series of three sermons on the issue. In the fall of 1790 , while browsing in a Boston bookstore, Morse came across a recent edition of religious songs for children by Isaac Watts; he quickly saw that all references to Christ's divinity had been removed. Alarmed, Morse wrote the Boston Centinel in order to alert the public of the presence of this dangerous book. He argued that if such alterations in children's books passed unchallenged, whoever was responsible would grow bolder and "every sacred truth of the Holy Bible may be in danger." From his earliest days in Charlestown, Morse was a tireless watchman, defending the orthodox view of religious truth. ${ }^{6}$

Within two years of his arrival, the liberal clergy in Boston had marked Morse as orthodox and as an unsettling element in the religious commu- 
nity. The Boston clergy met once a fortnight, mostly for social intercourse, and, one supposes, for gossip and job talk. Morse quickly upset this happy scene by interjecting discussion of divisive religious issues. William Bentley, who would become a lifelong enemy of Morse, remarked in his Diary that "a Mr. Morse of Charlestown has begun a course of lectures upon the Trinity at the Thursday lecture. The clergy fear the controversy should be opened and the orthodox will be meddling with it." Bentley was typical of the liberal clergy in the Boston area (Bentley was from Salem). In contrast to Morse, Bentley ignored doctrinal issues; he defended the "man of religion" as "pure from guile, peaceable . . . gentle . . . easily dissuaded from revenge, with heart to pity and relieve the miserable, impartial in judgement, and without dissimulation." Bentley had little interest in creeds, doctrines, and complex theology. "Virtue alone is the moral happiness of the world, and personal virtue alone secures heaven," he said. This was the core of Boston liberal religion; there was almost no room for piety, the irrational, innate depravity, or discussions about the nature of the Deity. The emphasis was on "works," on Christian behavior; for Morse this was never enough. He labored to make clear exactly how far the bulk of Boston clergy had moved from the creed of New England's Puritan fathers. ${ }^{7}$

By no means was Morse alone in the orthodox camp. In 1793, with Morse's help, Abiel Holmes, his boyhood friend from Woodstock and Yale classmate, was installed in the pulpit at Cambridge. Morse was also helpful in the process that brought David Tappan to Harvard as professor of theology. Both men provided Morse with stout orthodox comrades. In addition, Morse corresponded regularly with men of moderate Calvinist sympathies outside the Boston area. Ashabel Green of Philadelphia wrote Morse in 1792, "Pray how do you get along with your liberal brethren. Are you all associated together still? Do they hate and persecute you?" Green supported Morse's growing belief that the continued association of ministers with sharply different theologies was "ludicrous." Morse also developed a relationship with Henry Channing in New London, Connecticut. Apparently he had asked Channing how one dealt with ministers and laymen who held erroneous beliefs; Channing suggested that his Charlestown friend preach the truth plainly and let his listeners deal, in their own hearts, with differing visions: "Errors in doctrine are to be combated only with weapons of truth."

Thus, by the early 1790s, Morse had taken up his position as one of the orthodox in eastern Massachusetts, an area that was becoming a center of anti-orthodox thinking. Although Morse had glimpsed the rising liberal challenge to Calvinist thought, he also had come to understand another reality: he could get rich selling geographies. His father and friends complained that writing was taking Morse away from the most important 
task, his work for Christ and true Christianity, but Morse nevertheless wrote on. In 1793, he published, in two volumes, the American Universal Geography, and it sold well. Geography Made Easy appeared as an abridgment of the Universal in 1794, and Morse produced a geography for younger readers (age eight to fourteen) in 1795 called Elements of Geography. Between 1789 and 1795, he produced a geography for every level of reader.

The Universal Geography of 1793 became the base text for all the rest of the geographical system. The largest change between the 1789 and 1793 editions was the development of a full second volume on Europe and the Eastern Hemisphere. Morse was responding to what he saw as the market conditions for geographies; colleges that taught geography sought a work that fully deciphered the Earth. A one-volume work, almost wholly on America, required the continued importation of a geography from Europe, something Morse was trying to end in 1793. Morse was nationalistic; he wanted Americans to read American books. Almost every preface or introduction he wrote complained that Europeans distorted the story of America. Although perhaps heartfelt, his nationalism was also good business. Morse understood that his work was the new product in a market English and European works had long dominated. He was also capable of doing more than writing nationalistic prefaces in order to manipulate that market. In 1794, Morse agreed to a proposal from Matthew Carey that he would rewrite and revise the United States section of Guthrie's Geographical Grammar, an English geography long a staple in America. He agreed to do the revision and provide new copy if Carey promised not to publish an octavo edition of Guthrie's geography and keep Morse's role a complete secret. Carey eventually promised to cease for five years publication of the large Guthrie geography that would compete directly with Morse's Universal and the deal was made. Morse received three dollars a page for new copy and one dollar for revised pages; in all, he produced 160 pages for Carey, and in the bargain eliminated for five years one of his most important competitors.?

The 1793 edition also benefited from Morse's involvement with Isaiah Thomas, the printer of the work, and Matthew Carey of Philadelphia, who eventually helped to distribute it. Thomas wrote Carey in March 1795 with a proposal that greatly expanded the distribution of Morse's books. If Carey would promise to take one-third of the future printings of the Universal and the abridgment, Thomas would allow him to sell one-third of the remaining Universals and abridgments. Thomas reported that of the original press run of the large geography, only nine hundred remained of four thousand. Thomas had printed five thousand copies of the abridgment and had sold half the edition in ten months. If Carey agreed to the deal, which he did, Thomas proposed that they begin immediately on a 
new edition of the Universal (six thousand of volume one, forty-five hundred of volume two). Thomas suggested to Carey that it would be a profitable business for a long time. "To keep pace with the country," he argued, Morse would have to produce a new edition "about every two years."10

Although Thomas and his partner, E. T. Andrews, were excited about the prospects for Morse's geography, they were not fond of Morse. The correspondence between Thomas and Morse was full of recriminations and mutual suspicions. E. T. Andrews, in his letters to Thomas, revealed exactly how they viewed Morse. Thomas and Andrews paid Morse on some sort of payment schedule as the books sold. When Morse asked for copies of the Universal and wanted the cost subtracted from "the last payment," Andrews was appalled at his presumption. Andrews also believed that Morse was selling some of the one hundred gratis copies of the Universal allotted to him. Andrews got so infuriated by Morse's greed that he coined the term "Morseish," which he defined as someone who "loves money and knows how to get it." Although Morse could rationalize his geographical writings as a duty and national service, at least Thomas and Andrews, his printers, thought he was in it for the money. ${ }^{11}$

The appearance of the 1793 edition of the geography did more than push Morse fully into the book business. It also produced a fuller critical reaction than any of his previous efforts. Morse's critical views of the South elicited substantial criticism; some of it came in personal letters, but more important was the published pamphlet by St. George Tucker of Virginia. Tucker took warm exception to Morse's short, but very negative, description of Williamsburg, Virginia, Tucker's hometown. A judge and professor at the college, Tucker sarcastically claimed that "a few more touches of the reverend Geographer's pen would have exhibited to us Sodom and Gomorrah on the eve of eternal wrath." Morse acquitted himself well in this situation; he wrote an apologetic letter to Tucker and sof tened his description of Williamsburg in later editions. ${ }^{12}$

Much more substantial and important was the critical pamphlet produced by James Freeman, the minister of King's Chapel in Boston and a student of geography. Freeman's pamphlet contained an exhaustive critique of Morse's geography. Objections ranged from the petty to the substantial. Freeman was, for example, amazed that Morse had claimed that the "Surrinam peccary" had a navel on its back and that Morse had uncritically accepted reports of lions and tigers in Mexico. Reading beyond such criticisms, Freeman's pamphlet illustrated some of the religious and intellectual controversies in Boston in the early 1790s. Freeman claimed that Morse's religious views influenced the geography. In his description of Massachusetts' Congregational churches, Morse had claimed there was great disharmony and degeneration. Freeman accused Morse of finding disharmony 
where there was only healthy disagreement over "doctrines." He strongly implied that Morse's views were guided by a desire to have "a consociation of churches" that would insure doctrinal homogeneity. Freeman suggested that such a plan would split the churches into factions. He also took exception to Morse's characterization of Rhode Island. Morse harbored little love for Rhode Island, but Freeman stretched to pin Morse's animosity toward the tiny state on Morse's supposed dislike of the Baptists who were common there. In the Universal, there were no overt antiBaptist statements, so Freeman retreated to the 1784 edition of Geography Made Easy in which Morse called Baptists "litigious" and "illiterate," a statement omitted from later editions. Freeman argued that Morse's hostility toward Rhode Island stemmed from an intolerant temperament and a love of religious establishments. In addition to defending Rhode Island, Freeman criticized Morse for his bias against the South. Going beyond Tucker's limited complaints, Freeman claimed that Morse "does everything in his power to raise the character of the eastern states, Rhode Island excepted, and to depress that of the southern states." This was certainly a fair charge; Morse never attempted to answer it.

Freeman's pamphlet was important also for what it did not touch upon: politics. Freeman and Morse could quarrel over the Universalists or the state of affairs in Rhode Island, but they left politics alone. This did not mean that geographies were not political tracts, or that Morse was not a political creature. He, like most Bostonians, was a Federalist without thinking about it very much. Men like Morse were drawn into the Federalist ranks because they aligned themselves with established authority. Much more than self-interest made Morse a Federalist; he naturally associated himself with those who exercised political, moral, and economic power in Massachusetts and in the nation. Morse saw the Federalist administration after 1789 as representative of the traditional, the fixed, and dependable. ${ }^{13}$

Morse also stood behind the Federalist standard because at the head of the troops was General Washington. Morse illustrated his devotion to Washington in one of the strangest, but most significant, sections in 1789 American Geography. In a book that saw slavery and the plantation system as the ruin of the southern character, Washington, owner of both slaves and a plantation, emerged as the embodiment of American virtue. He was, first of all, industrious; the great man "lives as he has everdone, in unvarying habits of regularity, temperance and industry." On his estate, "order and economy are established in all departments, the General's household purchases no foreign goods, producing everything for their use under their own roof." Finally, Washington's slaves were, in Morse's hands, turned magically into "labourers." Mount Vernon almost glowed with vir- 


\section{A Period of Singular Revolutions}

tue; it was, in Morse's imagination, transported to the Connecticut countryside, where Washington shed his status as Virginian and became cousin to the New England farmer. Morse saw in Washington, and in the party he led, exactly what he wished to see. Devoted to an image of republican virtue and simplicity, Morse altered the reality of Washington to fit the image. The government had to have at its head a leader modeled after the typical New England patriarch; Morse was capable of turning a Southern slaveholder into just such a figure. For most of the 1790s, Morse would exhibit an almost slavish devotion to Federalist leadership. He was never able to see their flaws or to take a critical stance toward Federalist policy. For Morse, Washington and other leaders were fathers to whom the people owed uncritical respect and devotion (AG, 131-32).

Indeed, if the rulers were fathers, the people were children. Social solidarity was rooted in this parent-child relationship. The Christian stood as a guilty child before a demanding patriarchal deity, and this relationship was duplicated in the earthly family. Patriarchal governance in the church and family became a pattern for governance in the state. In all aspects of human life, Morse assumed there was a pattern of domination and submission, of parent and child. In this pattern there was little room for the idea of autonomy or the development of a fully free individual. The community (family, church, state) always meant a hierarchy of ranks and degrees to which everyone submitted; peace, harmony, and virtue depended on the people's submission to this reality. Morse saw hierarchy and the family metaphor increasingly challenged; particularly in national politics, the Jeffersonian challenge seemed to be a rebellion by unruly children against virtuous parents. In his own town and congregation, the ideal of harmony based on grateful, deferential children ruled by virtuous leaders was clearly undermined. As the challenge became more widespread and effective, Morse, at first, attempted to understand it and battle it. With Jefferson's election in 1800, Morse was plunged into despair; but soon he was back at the front with new plans and projects to save the world of patriarchal and hierarchical values.

Morse's pugnacious stand in the early nineteenth century was a marked contrast to his euphoria between 1789 and 1794 . This euphoria had its roots in a number of sources. No doubt it reflected his own personal success: he occupied a prestigious pulpit, his geographies were making him rich, his geographies were also making him a figure of national reputation who corresponded regularly with important Federalist officials such as Oliver Wolcott, Jr., and, finally, by 1795 his family had grown to include three healthy sons. Morse's optimism, however, was based on more than just his personal success. Between 1783 and 1789, he had often expressed his anxiety about the state of the nation. Although he extolled 
New England's virtues in his geography, on several occasions Morse stated that he knew all was not well. Shays's Rebellion in 1786 alarmed him, and he worried that "this flame" would spread to Connecticut "as there is so much tinder in Windham County-and particularly in Woodstock." In the 1789 geography, Morse argued that the Revolutionary War had provided Americans a common enemy and that when the British were defeated, a number of political and social "defects" appeared. Each state had too much power and few sought to protect the common good. The British had aroused the desire to protect individual liberties, but when this danger dissolved, "the fears of the people changed their object, and were turned against their own rulers." Throughout the new nation in the 1780s, a "jealousy of power had been universally spread among the people of the United States"; they had lost "their habits of obedience" (AG, 113-14, 117).

The Constitution and the election of Washington greatly reduced Morse's anxiety. In July 1788, he wrote his father that the Constitution was "a grand machine constructed by wise men and I hope and trust that ... it will diffuse peace, harmony, prosperity, and happiness throughout our land." No doubt Morse believed that the Constitution would bring great practical benefits; in contrast to the Articles of Confederation, Morse believed the Constitution would allow the United States finally to develop a coherent trade policy and that under the new government, commerce would flourish. Yet the Constitution also had a singular psychological effect on Morse. In the American Geography of 1789, Morse portrayed a nation fragmented and plural. With the notable exception of New England, the country was without a unifying character. The South and the middle states, flawed by the sin of slavery and cursed by ethnic and religious pluralism, were without direction. They had no head, no leadership class to serve as a guide and to enforce political and moral virtue. The Constitution brought to the United States a political structure very much like the one that he liked to believe existed in New England, and especially in Connecticut. With the coming of the new federal government, the disarray and pluralism that Morse had lamented in all the states but those in New England could disappear. The family metaphor could be applied to the states; they would now be governed by one head. It was in this context that Morse's transmogrification of Washington into a virtuous, industrious New Englander becomes clear. In Morse's vague and ultimately irrational political ideology, the ratification of the Constitution and the election of Washington signaled the New Englandization of the United States. ${ }^{14}$

With a new frame of government and a patriarchal figure at its helm, Morse set about insuring the existence of a passive and deferential people. In the Elements of Geography, the "Master" who directed the catechism section of the book asks the "Pupil" his response to learning about the United 


\section{A Period of Singular Revolutions}

States. To this, the thousands of students who used the book were instructed to respond: "I am truly delighted, Sir, with the account you have given of my country, and I am sure I shall love it more than I ever did before. I hope I shall always be disposed to respect and obey my rulers. The Bible tells me I must do this."15

Morse was not so plain when he spoke to adults. Rather than call bluntly for respect and obedience to government, he hammered away at the theme of gratitude. Indeed, gratitude was, for Morse, perhaps the most important emotion; it was a key to his emotional universe. The first and most important human obligation was gratitude for favors received and for timely and corrective afflictions. In the family, the children must feel grateful to the parents for their guidance, support, and training. The people of a nation must feel grateful to good and wise leadership, but ultimately all thankfulness must flow to God, the source of all prosperity and afflictions. Thus, gratitude was the essential obligation of the child, the citizen, and the Christian believer. In each role, gratitude implied a measure of self-abasement; prosperity, good government, or the expansion of true Christianity were never the products of human will, they were the gifts of Providence.

Morse overtly argued his case for the necessity of gratitude in two sermons, one in 1789, the other in 1795. America's political success in the period since 1776 was not the product of chance or human effort, it was instead "a long series of special . . miraculous interpositions of Providence in our behalf." The spirit of the American Revolution had, Morse noted in 1789, passed to France, where it was "making rapid and glorious devastations of tyranny, superstition, and ecclesiastical oppression." To believe that these developments "were matters of chance-such as naturally result from our situation" was to deny the supremacy of God and Providence and to worship nature and history. The Americans in the Revolution, Morse argued, were much like the Israelites; the American victory over the British (the "Egyptians") was a redemption granted by God, not the product of human will. After such salvation from peril, many peoples had praised God for his blessing only to forget that "their history is but the history of miraculous favors conferred, and of the ungrateful return of murmuring-rebellions-and transgressions of his [God's] laws and his covenant." Americans should realize their special status and thank God for the Constitution and that God had given Americans "at this forming period of our infant Empire a Washington and an Adams." Morse concluded his 1789 sermon with a clear statement of what was a central element in his thought: "Gratitude is a natural duty-interwoven in our very constitutions. To be ungrateful for favors received is to counteract one of the plainest dictates of our natures." 16 
By 1795 , Morse was still essentially optimistic, but he was also more anxious than he had been six years earlier. He began his 1795 sermon by noting that this occasion of thanksgiving would be more glorious if "there were good reasons to hope that all those gathered were of the number of true worshippers of God and felt towards him true gratitude ... for his mercies." Morse was also more anxious about affairs in France. He noted, with approval, France's military success; the def eat of the Jacobins, "a dangerous combination of sanguinary men"; and "the adoption of moderate and rational measures"; and he hoped there would be "a speedy termination of the spirit of Vandalism." Beneath this glowing report, however, lurked real worry about the events in France. He noted that a true and lasting peace between France and her enemies was not likely, and that "jealousies and party-spirit" still plagued France "and require to be watched with a vigilant eye." The situation in France reminded Morse of the United States between 1783 and 1789; both nations divided into parties when the external pressure dissolved. "If we may judge from our own revolution," Morse suggested that France would fragment "and it will probably take years to form and establish a government which will unite all interests ... though, I firmly believe that they will finally overcome all intervening obstacles and obtain such a government." Morse was remarkably unconcerned about irreligion in France. He believed that "the rejection of the Christian Religion in France is less to be wondered at, when we consider, in how unamiable and disgusting a point of view it has been there exhibited, under the hierarchy of Rome. When peace and a free government shall be established, and the people have liberty and leisure to examine for themselves, we anticipate, by means of the effusions of the Holy Spirit, a glorious revival and prevalence of pure, unadulterated Christianity.-May the happy time speedily come!" This sentiment was at odds with the position he had held only three months earlier. In the published edition of the 1795 sermon, he included a section from his 1794 Thanksgiving sermon that flatly stated that many of the revolutionary excesses of 1793 and 1794 could be explained "but for their cruelties, and especially for their impieties, we can find no adequate excuse." In the long run, Morse was unsure about religious radicalism in France; confronted with such sweeping change in the nation's religious structure, he both forgave and censured.

The long analysis of the French situation, and equally extensive discussions of other nations, served as a prologue to his views on the domestic scene. In comparison with the rest of the world, the United States, Morse argued, was surely the favored child of God. America in 1795 was distinguished by the bounty of its blessings; the United States was at peace, but the nation had just passed through a period of great danger. The British actions against American commerce had very nearly led to war. The French had 


\section{A Period of Singular Revolutions}

attempted to influence domestic politics and had sown "the poisonous seeds of a party, disorganizing spirit." The French influence had been visible in all parts of the country, but nowhere was this influence so frightening as in the Whiskey Rebellion in Pennsylvania. Morse lavishly praised the "decisive and reasonable measure adopted by the Supreme Executive ... to check and counteract this dangerous foreign influence." The defeat of the whiskey rebels Morse linked with the "happily concluded foreign negotiation" with Britain over commercial matters and "the recent happy change" in the French government, and he concluded that America had narrowly escaped a disastrous war with one European power or the other.

America was not only at peace in the world but also marked by "internal tranquility." Again the sermon was optimistic, yet with the sense that the nation had barely avoided disaster. In this context, Morse returned to the Whiskey Rebellion in order to praise the government for crushing it. For him, the question was "whether we should be governed by a mob, or by our legal representatives?" Morse was encouraged by the public support for Washington's strong actions, for the "zeal and patriotism" that animated the troops under the president, and for "the general applause they received from their grateful fellow citizens." Morse seemed almost thankful for the outbreak of the rebellion because the humiliating defeat of the rebels would "operate to discourage ambitious and unprincipled demagogues from making the like attempts to interrupt our peace in future-and to increase the confidence of the people in the stability, energy and promptness of our Federal Government."

After listing a number of other domestic blessings, Morse moved to his conclusion. The world, as he saw it, presented a gloomy scene of war and oppression. The United States had been spared and stood as a contrast to the desolation in Europe and the oppression and slavery in Asia and Africa. Given this portrait, Morse suggested, "our gratitude should bear a proportion to our blessings." Citizens of such a favored nation have a special responsibility to be obedient and thankful. Americans were a chosen people who were given much by Providence, and they must remember that God's disfavor toward the chosen will be as ample as his blessings"our national and individual sins . . . will be attended with peculiar aggravations-Let this consideration operate as a powerful dissuasive from sins of every kind."

What sins? Morse feared most of all "pride and self-conceit," "arrogance in our prosperity," "vain glory, self-importance, and self-complacency," and the feeling that prosperity makes "men feel independent of their fellow-men, and even their God." The essential message of the sermon was Morse's injunction: "To keep our minds properly balanced and humble, when things go well with us as a nation, or as individuals, we should con- 
stantly bear in mind, that it is not we ourselves, but the LORD OUR GOD, that maketh us rich, and causeth us to be prosperous and happy. Besides, prosperity in this world does not always mark the best nations or the best men."17

Such sentiments were part of the long tradition of American jeremiads. Since the early seventeenth century, New England ministers had warned their congregations of the perils of prosperity. They had urged hard work and profit-seeking, but sought to head off the arrogance and pride that came with success. Coming from Jedidiah Morse, however, these words have special significance. As he spoke to his congregation on a Sunday in February 1795, Morse was rapidly becoming rich, and he was doing it by neglecting his ministerial duties. By 1795, Morse had his full system of geographies on bookstore shelves, and he was making plans to publish gazetteers as his avaricious reputation was growing. Certainly there was a public Morse reflected in his sermons that bore some relationship to the private, acquisitive Morse. For Morse personally, the sermons were ritual acts that denounced the behavior he engaged in privately. Plagued by guilt and anxiety because of his publishing activities and his father's disapproval, Morse responded by adopting a stance in his public sermons that urged gratitude and self-abasement; these sermons condemned the pride and arrogance that too often came with national and individual prosperity.

As a public statement, the 1795 Thanksgiving sermon marked the end of Morse's euphoria about the state of the nation. The Constitution, the presidency of Washington, the general prosperity of the first half of the 1790 s, and his personal success as an author and minister all erected an optimism in Morse that the radicalism of the French Revolution, its influence in the United States, and the Whiskey Rebellion could not quite dampen. Until the spring of 1795 , Morse could believe that his treasured image of social solidarity, of a community of patriarchal leaders and grateful, obedient, and deferential people, was still a reality. Certainly he had rationalized away much evidence to the contrary, but, beginning in the summer of 1795 , Morse's ability to see the rosy side of public affairs collapsed.

No doubt, an important cause of this collapse was the public outcry and condemnation of the Jay Treaty. In the spring and summer of 1795 , as the provisions of the treaty with Britain penetrated the public mind, Jay and the Federalist administration were vilified in many parts of America. To many Americans, the treaty looked like a total capitulation to Britain. Suspicion that the Federalists were Anglophiles suddenly turned into hardened belief. Town meetings throughout the nation condemned the treaty; mobs roamed the streets and burned the treaty and effigies of Jay. Morse witnessed the upheaval firsthand in Charlestown and Boston, but, equally as important to him were the views of his father. Drawing his information about the 
situation in Charlestown from letters and stories printed in the Windham Herald, the Deacon described "the Conduct of the Majority" as "very ridiculous and unwarranted." He assumed that his son was an eyewitness, and that the proceedings "must give you Disagreeable feelings, to see and hear such discord among your people." The meeting, the father concluded, was dominated by "a mere mob who were Determined at all costs to condemn the treaty and its advocates." Soon the meeting degenerated into bedlam, the mob shouting down all who called for reason and moderation. The old man concluded, "What my son shall we think of these things?"18

Morse replied that "the Treaty has created a great deal of heat and fever among us without any just cause." The treaty was valuable to the United States "as it secures us Peace, which we could not have on any other terms." He suggested that the leaders of the opposition were abandoned men who "wish to overturn our government for having nothing to lose they have some chance to be gainers in the general scramble - at any rate many of them cannot be worse off than they are now." Morse thought that, regarding the opposition to the treaty, there was a great contrast between the seaport towns and the rural areas. In the long run, he depended on "the stability and good sense of the yeomanry of the country" to bring the whole nation back to sanity. In contrast to Connecticut, "the best governed state in the Union," Morse thought that "in seaports there always will be a mob at the command of any artful Demagogue." In fact, the letter was remarkable, not so much because of his comments on the Jay Treaty hysteria, but because he saw the uproar in a larger context. For the first time, he condemned Boston in general terms. The entire Boston area was in the midst of prosperity and general healthfulness (a key issue in a decade marked by frightening epidemics), but Morse claimed "we [Bostonians] are almost as remarkably wicked, as we are favored. The increase of infidelity, uncleanness, Sabbath breaking, and all that flood of iniquity which springs from these is very alarming. We seem to be filling up the measure of our iniquities very rapidly." 19

The source of these sentiments had roots in Morse's personal contact with the mob and his relationship with the Federalist officials. Morse's nineteenth-century biographer, William B. Sprague, claimed that during the Jay Treaty uproar, Morse confronted a Charlestown mob burning an effigy of John Jay and was hit by an unknown assailant's "brickbat." $\mathrm{He}$ was not seriously hurt, but surely this must have helped to undermine his belief that Charlestonians were his flock and were willing to defer to his spiritual and moral eminence. Morse was also influenced during this period by his steady correspondence with Oliver Wolcott, Jr.; his most regular connection to the Federalist administration. Wolcott, secretary of the 
treasury, was also from Connecticut and a Yale man who apparently shared many of Morse's feelings about the national situation. As early as June 1794, Wolcott was sending Morse dark portraits of the state of the nation. He thought that "a mental epidemic is spreading through the world and threatening all Society with destruction." Wolcott, like Morse, saw no place for public debate of public issues, and his fondest hope was that "we should cease to contend in regard to subjects which intimately affect our government, morals, religion, and State of Society." Also like Morse, Wolcott felt that the situation was a contest between the salutary habits of rural New England and "the mental epidemic" so common to seaport towns. ${ }^{20}$

By the fall of 1795, Wolcott, after experiencing the full impact of the Jay Treaty hysteria, had worked his anxieties into a full-blown conspiracy theory. He wrote Morse that, over the last two or three years, there had been many events "which separately considered appear unimportant, yet in the aggegate [sic] they possess much influence. No division has complete knowledge." Wolcott's vague sense of "a mental epidemic" had hardened into a belief that "there exists a general combination to involve the U.S. in trouble." He suggested that "men of reflection . . . are anxious to investigate the real cause of those agitations which exclusively happen in our great towns. It is certain that they do not proceed from public misfortune, or from a sense of actual oppression. What do these things portend?"21

This question stuck in Morse's mind. Less than three years later he attempted to answer it in a series of sermons that pushed him into the national spotlight and ultimately brought him no small measure of disgrace. The three sermons (on May 9 and November 29, 1798, and April 25, 1799), taken collectively, amount to Morse's personal response to the times. In them, he claimed that the government and religion of the United States was the target of a vast conspiracy directed, generally, by France but more specifically by a shadowy group called the Bavarian Illuminati. Morse's main source for this accusation was a book by a Scottish professor, John Robison, called Proofs of Conspiracy Against all the Governments and Religions of Europe. After Morse opened the issue, a number of other Congregational ministers took it up, and soon much of the nation was debating the truth of Robison's charges as conveyed to them by the clergy. ${ }^{22}$

To understand fully Morse's sermons on the Illuminati, one has to see them in full context. The sermons were the product of a web of pressures that bore in on Morse; these forces were so complex that the resulting sermons pushed and pulled in so many directions that they were barely coherent. In the first place, the sermons were designed to serve the Federalist administration, and Morse persisted in the Illuminati crusade because highly respected Federalists approved of his efforts. After the first sermon, Morse wrote Wolcott claiming that the citizens of Charlestown, "many of 
whom have been violently opposed to the measures of Govt. . . have received the sermon with 'approbation." In a letter to Timothy Pickering, secretary of state, Morse included a copy of the November 1798 sermon and asked that "it may be communicated to the President." He claimed that he lived "among a people many of whom err in Sentiment and Conduct through their want of information." The sermons, Morse claimed, were especially designed for these misinformed souls. ${ }^{23}$

As the controversy over the Illuminati grew hotter and Morse was defending himself against charges on all sides, he received encouraging letters from exalted Federalists. In February 1799, Morse received a letter from his hero, George Washington. The retired president approved of Morse's sermons and encouraged him to publish and widely distribute them. Morse received much the same sort of praise from John Jay. Jay was happy to see that "the clergy, at least, of this country seem determined that the dead Bodies of the witnesses shall not be put into graves." Jay had read Robison and wrote Morse that "credit is due to the facts which he relates; and the credibility of them certainly derives force from the Extinction of Religion and Morals in France." Such encouragement helped, but all-too-obvious splits in the Federalist ranks increased Morse's anxiety over public affairs. His connection with Wolcott put Morse in the camp of Alexander Hamilton, who, operating through Wolcott, Pickering, and others still in the administration, fought President Adams at every turn. Morse's rabid fear of the French put him temporarily, at least, into the Hamiltonian faction that sought war with the French and fought every attempt by Adams to negotiate away the differences between France and the United States. Morse liked to think of himself as a soldier, on the local level, fighting ignorance and division on behalf of the national administration. Between 1798 and 1800 , this was increasingly difficult to do. ${ }^{24}$

For Morse, the split in the Federalist party was only one aspect of what seemed like the total collapse of social solidarity at the very end of the eighteenth century. In addition to the division among Federalists, the Republicans were constantly gaining strength in the years between 1796 and 1800. Morse simply could not deal with the idea of a political party challenging the party in power. His response to the Jeffersonian challenge was irrational; he transformed the political faction led by Jefferson into "Jacobins." They became the American manifestation of French principles and irreligion. As the eighteenth century drew to a close, Morse and many others like him believed that American society was on the verge of flying apart. Political factionalism was but one piece of evidence; Morse, in 1795, had grown increasingly concerned about "irreligion" or "infidelity." He assumed that true Christianity, with its emphasis on submission, gratitude, and deference, was the best, if not the only, basis for a republican govern- 
ment and a good society. By 1798 , he was convinced that true Christianity was under attack. The books of Thomas Paine, such as The Age of Reason, which ridiculed revelation and Christianity in general, were but the leading edge of what Morse saw as a concerted attack on the religion he had sworn to defend. ${ }^{25}$

Thus, the sermons that launched the crusade against the Illuminati were delivered by a minister who sought to serve the national administration, and who believed that good government and true religion were under attack by insidious forces that he increasingly labeled "Jacobin" or "French." Even this, however, was not the complete context. The minister who took to the public pulpit in 1798 and 1799 was also keenly aware that as a minister he was failing. He was also aware that his parish had become a battleground, and, finally, he recognized that his very identity as a minister was at stake. When he came to Charlestown in 1789, the church contained 135 members; in 1800, the membership stood at only 143. The number of female members had risen from ninety-two in 1789 to 115 , but the number of males had dropped from forty-three to twentyeight. Morse was losing heads of households and his church was increasingly composed of widows, single women, and wives who joined without their husbands. This lack of growth contrasted sharply with the rapid growth of the Charlestown population. In 1789 , the population stood at 1,579; it grew to 2,751 by 1800 . Given these figures, the sermons of 1798 and 1799 may well have been an attempt at self-promotion-an attempt to stir up interest and respect for a minister and a church that was languishing. ${ }^{26}$

Morse saw the town as a battleground between saints and strangers. In a sermon to his church at the end of 1799 , Morse claimed that prosperity had produced not thankfulness but an outburst of immorality. Everywhere "the vices of profane swearing, sabbath breaking, gaming, and dissipation, intemperance, lewdness and covetous selfishness, slander and evil speaking in all its branches" had crept into Charlestown. Family prayer and government had "fallen into disuse"; "our youth appear to be growing up without restraint, without knowledge, without principle, and, of course, without morals." Even within the church, discipline "on which its purity and respectability essentially depend has grown much too lax." This failure of discipline had allowed the rest of the town "to discredit our holy religion and to bring the church into contempt and to prevent its increase and give occasion for infidels to triumph."

Morse attributed the immorality and irreligion of Charlestown to the nature of the population. For most of the 1790s, Morse had looked suspiciously on the great number of newcomers. In 1799, he suggested the town take action: 
Good policy would encourage the settlement of wholesome persons of industry, good morals and prosperity, but would bar as far as possible the settlement of the idle, the intemperate, the unprincipled, and the poor. Of the latter we have already too many and as those of the same disposition and habits naturally associate there is a great danger of their increase, till at length they become a serious calamity. Our civil Fathers whose business it is to manage the policy of the town from their known regard for its moral, religious as well as temporal welfare will it is hoped pay all needful attention to this important business.

Indeed, this flood of newcomers would not lessen during Morse's years in Charlestown. Spurred by general prosperity, the construction of the Federal Navy Yard and the arrival of people pushed off the land in rural New England, Charlestown's population grew rapidly. From approximately sixteen hundred in 1790 , it grew to almost sixty-six hundred in 1820 . The decennial rates of increase were high for the Boston area; between 1790 and 1800 the population increased 73.8 percent; between 1800 and 1810 it was 80.3 percent; and during Morse's last decade in Charlestown, 181020 , the population grew 32.9 percent. $^{27}$

Thus, Morse had much local evidence for his belief that society was disintegrating. His vision of a homogeneous New England, with the same manners, morals, and religion, was clouded by what he saw in Charlestown in the 1790s. The notion that New England should serve as a model for the nation, a notion so prominent in The American Geography of 1789, was clearly on the verge of dissolving before Morse's eyes. In this context, the idea of a vast conspiracy against the very ideas of society and order made psychological sense to Morse. Without the personal or intellectual resources to understand the social and political transformation that swirled about him, Morse, as did many others, found sense and comfort in John Robison's fantasy of a shadowy cabal that sought to undermine all that was good and true.

Finally, the Illuminati crusade had roots in Morse's own psychological problems. By 1798, Morse's reputation as a minister with a desire to make books and money had become general knowledge. His devotion to his geographical labors and the failure of his ministry, in minor and indirect ways, rose to the surface during the Illuminati crisis. The editor of Boston's Independent Chronicle suggested that the Charlestown pastor shortchanged his flock each Sunday because he was "too anxious about the geographical description of the city of Washington or Georgia Land" and paid too little attention to "the New Jerusalem or the Land of Canaan." Morse was, the editor claimed, "busy about many things" during the week and, as a result, failed his congregation on Sunday. Given all this, Morse "must expect that his 
flock will not increase, and at the year's end, while he is exploring the territory of the United States, and hunting up Robinson's [sic] Straggling Illuminati, he must not be surprised if some of his own sheep have strayed across the river, and the care of a more attentive shepherd." The Independent Chronicle had also attacked Morse, by name, for meddling in politics. The paper had published a letter from "A Friend to the Clergy" in which Morse was urged to "attend to that important work, for which you were ordained; to be less attentive to the amusements, recreations and politicks of this world; to soothe the passions rather than inflame them."28

Morse took advantage of the trying times of the late 1790s to reaffirm to himself, his congregation, and his town, his identity as an "attentive shepherd." Highly sensitive to the barrage of criticism directed at him personally and at the established clergy, Morse claimed that the average minister's "little all of property stands on the same basis with that of their people, and the same events affect them equally. Could they not subsist in as much ease and affluence as they now do, by other professions? Are their stipends or their prospects of promotion enviable or alluring? Can they then be your friends who are continually declaiming against the Clergy, and endeavoring by all means - by falsehood and misrepresentation, to asperse their characters, and to bring them and their profession into disrepute." ${ }^{29}$ Throughout the Illuminati sermons Morse condemned the "selfish spirit, an insatiable ardor to get rich." This spirit had "engendered speculation, fraud, embarrassments and bankruptcy." "An avaricious man," Morse claimed, "will always sacrifice the public good to private interest." 30

Morse conjured up an image of a ministerial class, of which he was a member, barely getting by, battling the growth of capitalist selfishness and individualism. In Morse's case, this was hardly true. By 1798, Morse had become, in the context of Charlestown society, wealthy and was investing and speculating heavily. One index of wealth in Charlestown was servants in the home. In 1798, of 454 families, only sixty-seven had servants. Morse had two: Nancy Shephard was a fixture in the Morse house from the beginning of their stay in Charlestown, and sometime in the 1790s, the family also hired Prince, who took care of the horses and other similar duties. Morse's investments were substantial: $\$ 431$ for a Massachusetts State Bond in 1791, $\$ 375$ for shares in the Piscataqua Bridge, and approximately $\$ 291$ for ten shares in the Massachusetts Turnpike. Morse's correspondence during the 1790s hint at other investments-in 1799 , for example, he was in Philadelphia to sell some "insurance shares." His records clearly show, however, that his most substantial speculation was in land. In 1797, Morse purchased from William Woodbridge a lot and house in Medford for $\$ 2,750$. In 1799, Morse paid Samuel Goodwin, a member of his congregation, twelve hundred dollars for three two hun- 
dred-acre parcels in Kennebec County, Maine. Again, there were hints that Morse's speculation in land went beyond his dealings with Goodwin and others; he owned parcels of indeterminate value in both Vermont and New Hampshire. Perhaps most interesting of all, Morse was lending money to one of his most important parishioners. In 1798, Morse lent Aaron Putnam twelve thousand dollars and took as security a mortgage on some of Putnam's property in Charlestown. Clearly Morse was not a poverty-stricken minister; he was a successful author who took in substantial cash beyond his minister's salary (approximately six hundred dollars, house, and wood) and, by 1799 , easily possessed fifteen thousand dollars in investments of one kind or another. By portraying clergymen, like himself, as common people getting by with "their little all of property" and lashing out at greed and speculation, Morse was attempting to affirm, for his own conscience and his audience, an image of himself as a self-sacrificing clergyman. ${ }^{31}$

When we read the texts of the sermons, it comes as no surprise that they seem to be devoted to a number of purposes. Morse never seemed content merely to argue for Robison's view of the French Revolution as an Illuminati plot. At times he suggested the existence of a more vague, more generalized conspiracy, dating back well into the eighteenth century, before the birth of the Illuminati. What remained constant, however, was the target of the conspiracy; it was always directed against the values and structures of the past. The conspiracy sought to create a contempt for the past and "those civil and religious institutions founded by our venerable forefathers and to prostrate those principles and habits founded under them." 32

Perhaps the most effective device Morse employed in his defense of the past was the list; the three sermons bristled with them. He would catalogue the goals of the conspiracy, creating in his audience a vision, in a negative way, of the world the Illuminati sought to create. Imagine, he asked his listeners, a world in which suicide was justified, in which heaven and hell and eternal punishment after death were banished, in which sensual pleasures were approved, in which liberty and equality were "inalienable rights," in which marriage was banned and there was widespread promiscuity. Morse asked his listeners and readers to reverse the list in their minds and affirm the virtues that the Illuminati sought to destroy. These virtues have a certain unity; they were all, for the most part, checks on individuals, standard values that Christian cultures imposed as law. Morse asked his audience to reject what the Devil had always wanted for mankind-unchecked freedom. ${ }^{33}$

Anyone who listened to, or read, all three sermons would certainly have seen the conspiracy as less important than Morse's insistence that the targets of the conspiracy be defended. The conspiracy against virtue, in fact, was not directed by free agents who chose evil ways; they were the agents 
of God "accomplishing his promises, and fulfilling the prophecies." The Illuminati were helping to bring on the millennium, the last days were at hand. The notion that immorality and social and political chaos were but the harbingers of the millennium played an increasingly important role in Morse's thought after 1795. Whenever the times depressed Morse, he tended to fall back on the idea of an eventual millennium and the idea of an all-governing Providence. In 1795, during the summer of the Jay Treaty uproar, Morse wrote his father, "Revolutions will not cease to take place in one part of the world or another till the Millennium shall commence and how soon that may be I pretend not to determine." 34

In the Illuminati sermons, Morse employed the idea of a coming millennium directed by God's providential plan to urge passivity and allegiance to the virtues of the past. The evil that seemed to dominate the world was somehow part of God's plan; a true Christian's duty in such times was to cling to the past and established Christian virtues. God employed sinners, such as the Illuminati, like a fire to bring about a more perfect world. From this, Morse deduced the moral lesson that dominated all three sermons: "Live in all due subjection to our rulers, and meddle not with them that are given to change." 35

For Morse, history and change were in God's hands; events, lives, and the efforts of men and women were of no real account. This comforting notion played a central role in Morse's life, and because it did, he found the last quarter of the eighteenth century an anxious time. To his credit, he realized, however dimly, that the very forms of explanation, the way mankind understood history, were changing. This change produced perhaps more anxiety than did the Illuminati. Morse stated that the "doctrine of a Divine superintending Providence" that had comforted "the people of God in every age" was, of late, "falling into discredit and neglect before the impious principles of the new philosophy." "Our pious ancestors" had understood history and natural events as solely the work of God. This tradition, Morse perceived, was threatened by the fashionable tendency "to ascribe these things to the uncontrolled operation of natural causes, and to keep out of view the Divine agency." 36

Morse elaborated on this theme in several ways. He found in Rome an example of a society that had collapsed because it lost its sense of a divine hand controlling its destiny. Once the Romans lost their belief in Providence, they gradually lost all that was valuable in their civilization. Morse also used the epidemics that had ravaged Boston in the 1790s as an example of the workings of Providence. Yet clearly he was caught between two modes of explanation. Science, he asserted, should seek the "natural causes" of the outbreaks and remove them, but he also insisted that "we have no good reason to expect that this calamity will not cease from 


\section{A Period of Singular Revolutions}

among us, till the moral causes be removed, till we acknowledge the righteous hand of GOD in it, and are truly humble for our sins and reform our lives." The epidemics were both natural events open to investigation and elimination and calamities "brought upon us in judgment by the special hand of Providence." Man was both a rational animal capable of controlling epidemics (and unearthing conspiracies and explaining revolutions?) and a criminal suffering the will of an omnipotent deity. Anxious, uncertain, and psychologically divided, Morse clung to the notion of a providential plan because this view provided some certainty in a chaotic age: "The history of Divine Providence proves its consistency and uniformity. What has been, will take place again in like circumstances. With God there is no variableness or partially." 37

Indeed, it was such statements as this that revealed one of the central intentions of the Illuminati sermons. Beyond the banalities about conspiracies, the massed footnotes that authenticated French atrocities, and the awkward attempts to justify the government's record, the animating public purpose of the sermons was to counsel and to help create uniformity and social solidarity based on allegiance to an image of a perfect past. For example, President Adams had called for a day of fasting and humiliation on May 9, 1798, the occasion for the first of Morse's sermons. Morse was appalled that some had argued that the nation had no need for such a day. Such "vile sentiments," such discord, "indicates a degree of corruption and depravity, in the public mind, more threatening to our dearest rights and interests, than the hostile attitude and movements of foreign nations." The conspiracy theory presented in the sermons sought to bring order and sense to a bewildering array of events that stretched back fifteen years or more. It was France that had caused "the unhappy divisions that have existed among us." It was "a deep-laid plan" hatched by the French that produced so much criticism of elected officials, the XYZ Affair, irreligion, the criticism of the clergy, the success of the French armies, the writings of Tom Paine, the rise of Jefferson, the democratic societies, the Whiskey Rebellion, and on and on. All these and more were the product of a French-Illuminati plan that was, in reality, a "dreadful fire" directed by God "to rage and spread" for His purposes. This view explained everytbing; the fragmentation of Christianity, the political disharmony, and the immorality in the streets of Charlestown were only seemingly unrelated elements in what was really a unified plan and Providence was at the wheel. ${ }^{38}$

The theme of wholeness and uniformity extended beyond political and social affairs; it included Morse himself. Essentially a divided and anxious man, he felt guilt because of his neglect of ministerial duties and his pursuit of wealth and reputation as an author. The sermons may have been attempts by Morse to heal this split in his sense of self. By arguing so 
vehemently for social and political solidarity, by characterizing the clergy as humble servants of the community, he was applying psychological cement to the cracks and splits in his own identity. Morse revealed this purpose more openly toward the end of the May 9, 1798, sermon. While in the process of listing the duties of Americans in the crisis provoked by the insidious conspiracy, Morse claimed that "as Christians, we ought to be alarmed for the safety of the church; to be vigilant in resisting the open and secret attempts to bring into disrepute and to prostrate our religious institutions. If these foundations be destroyed, and infidelity and atheism prevail, what will the righteous do? Let us then search for the Achans, the accursed things, among us, and let them be taken out and destroyed. Let us, each with care, inspect his own heart and conduct, and repent of, and correct, what he finds amiss." 39

In this passage, Morse was calling for his own punishment and the destruction of his greedy and individualistic self. In the sermon, Morse referred to himself as "a faithful watchman" and portrayed the clergy as a group who sacrificed money and chances for advancement in order to serve the community. In the passage above, he called for vigilance in resisting "open and secret attempts to bring into disrepute ... our religious institutions." Subconsciously, he was referring to his own actions, his own failure to serve religion. The facts indicate that he was not fully dedicated to his role as minister; he had an itch to make books, to ingratiate himself with the national elite and to speculate in stocks and real estate. To exorcise this element of his identity publicly, he called for the identification and destruction of "the Achans, the accursed things." Achan was a Judahite who, during the assault on Jericho, violated the ban on looting and took gold, silver, and clothing for himself. When the community discovered his crime, Achan, his family, and his possessions were destroyed. In reaching for this biblical image, which bore no relation to the imagery of the sermon as a whole, Morse performed ritual absolution. Covertly, he called for his own apprehension or identification as a sinner and his destruction as a violator of the rules against covetousness and selfishness. Such ritual absolutions were effective; they allowed Morse to maintain a dual identity without incurring debilitating guilt and anxiety.

The Illuminati sermons had both a private and public face. Privately, they were deeply entwined with Morse's sense of self and his personal desire to play a role on the national stage. Publicly, the sermons set off an eighteenth-century version of a media event. Many, like Timothy Dwight, rallied to Morse's side, seconding his charges against the French and the Illuminati. Others condemned Morse for meddling in politics and challenged virtually every aspect of Illuminati conspiracy theory. ${ }^{40}$ The public response to his sermons focused on two issues: the credibility of Robison's 
work and the relationship between the Masonic Order and the Illuminati. Morse had presented Robison's theory as truth without knowing much about Robison or his book, and he had failed to see that his insinuation that Masonic lodges might be cells of Illuminati would bring a storm of criticism.

Starting with the first Illuminati sermon in 1798, Morse was confronted with a rising tide of criticism. The Massachusetts Masons complained to President Adams, condemning Robison and Americans like Morse who helped spread his views. Dr. Josiah Bartlett, an influential member of Morse's church, wrote the Massachusetts Mercury to criticize Robison. Bartlett was the Masonic Order's grand master in Massachusetts, a fact that must have led to increased tension in Morse's congregation. Morse's most formidable problems, however, came from Reverend William Bentley of Salem. Bentley and Morse were at odds on a number of fronts; the Salem pastor was a religious liberal, a member of the DemocraticRepublican party and a Mason. When Morse began his Illuminati crusade, Bentley began a surreptitious crusade of his own to discredit Morse. ${ }^{41}$

Bentley rejected Robison's charges as preposterous. He provided Boston newspapers with British reviews critical of Robison. Morse, upset by the attacks on himself and Robison, countered with a series of pieces in the Massacbusetts Mercury. Bentley was not finished with Morse, however; in the spring of 1799 , Bentley found a way to put Morse in an untenable position. Both men corresponded with the German geographer Christoph Ebeling, and both received letters that ridiculed Robison and his work on the Illuminati. ${ }^{42}$

Morse's letter from Ebeling eventually led to considerable embarrassment, and his response to the problems posed by Ebeling's letter illustrated a central aspect of Morse's personality. In the summer of 1799, Morse was reading the letter to a friend, when, Samuel Huntington, a friend from Yale days, overheard at least part of the letter. In less than a month Morse learned of rumors circulating in Connecticut that Ebeling had written Morse condemning Robison as insane and a criminal (both charges were untrue and Ebeling had said nothing of the kind). Because Morse was unwilling to reveal the actual letter from Ebeling, he was never able to silence these rumors effectively. ${ }^{43}$

Bentley realized that he held the advantage over Morse, and he took it. In October 1799, he sent a copy of his letter from Ebeling to the Massachusetts Spy (Worcester), where it was printed as a letter from Germany to a correspondent in Massachusetts. Soon other papers began to reprint the letter as, in fact, being Ebeling's letter to Morse. Morse was furious, but trapped. The only way he could unmask Bentley was to submit his letter from Ebeling, but to do this would be to discredit his own interpretation of the letter. This was the key issue. How could Morse read a letter con- 
demning the Illuminati and Robison as evidence in support of Robison and, by extension, Morse? Morse pulled this off by dwelling on Ebeling's religious and political views. He characterized Ebeling to his friends as "of the new divinity or modern Socianism - which is very little different from Illuminism and in politics a modern French Republican." He concluded that "taking into view Prof. E's obvious political and religious opinions what he says against Robison's work so far from discrediting it confirms its authenticity and importance." To another correspondent, Morse suggested that those who opposed Robison were "somehow interested to do soI should mark such characters and see if they did not favor the spread of the principles of Illuminism in this country." 44

These statements reflect one of Morse's most common tendencies. Even as early as his years at Yale he divided the world into two camps: the elect and the damned. Ebeling, because of his religious and political liberalism, was labeled as among the damned. Morse assumed that such people were part of a plot against true religion and sound political principles (liberty with order). It was in their interest to lie or obscure the truth. $\mathrm{He}$ routinely attributed insincerity and duplicity to his enemies; this was particularly true of his relations with religious liberals after 1800 . This led Morse to collapse complex issues into simple ones. In the Ebeling affair, he ignored the complexities of the political and religious conflicts of the day and routinely characterized the conflict as one between a saintly band of political and religious moderates and a gang of lying atheists and political radicals. For example, Morse allied himself with the Hamiltonian wing of the Federalist party, which contained numerous figures, such as Hamilton, who hardly shared Morse's commitment to moderate Calvinism. Yet given his desire to simplify complex situations, Morse ignored the religious views of exalted Federalists.

How can one explain this habit of mind? For one thing, the 1790s were confusing and perplexing years; people had to accommodate rapid changes in American culture. They had to adjust to the existence of growing opposition to political power and religious establishment. Newspapers lambasted political figures, and, as in the Jay Treaty uproar, violently condemned the actions of the government. Religious change also pushed in on people like Morse; he was aware of pressure on the established Congregational church and its creed from the liberals, Baptists, and Methodists who sought equal footing with them. Many Americans, like Morse, concluded there was a vast conspiracy against good order and decency in all areas of life. Even given this explanation of Morse's habit of finding conspiracies and regularly charging his enemies with insincerity and disguising their true motives, we have hardly reached a full explanation of Morse's actions in the late 1790s. It is important to remember that Morse himself was 
not completely sincere and open in the Illuminati sermons. He was acting as an agent of Wolcott and the Federalist party, yet he presented himself as a disinterested member of the clergy whom he characterized as selfsacrificing and on the edge of poverty with only the interests of the people at heart. The sermons, Morse believed, would advance his reputation both in Charlestown and with key Federalists such as Wolcott. All this suggests that Morse was guilty of the same sort of duplicity with which he charged the Illuminati. Morse may well have projected a negative characteristic that he was unable to accept fully as part of his own personality onto a band of conspirators. Put another way, Morse maintained a public posture that was at odds with his private ambition and desires. He sought connections and approval from national figures and he pursued a lucrative career as a writer while essentially posing as a humble minister whose concerns were local and religious. Given this conflict between public and private roles, Morse became very sensitive to charges that questioned his character in general and his sincerity and honesty in particular. He dealt with this problem by projecting onto shadowy, ill-defined groups (Illuminati, Jacobins, liberals) the very characteristics he wanted to deny in himself.

Indeed, Morse's psychological state becomes the key to understanding his thought and behavior between 1797 and 1800. The habit of finding duplicity, insincerity, and disguised motives reached frantic heights. In June 1799, Morse wrote Wolcott a letter that contained his most vivid and revealing description of the conspiracy that faced the nation. He was "convinced that the Jacobins, like their father, the first Disorganizer can transform themselves into any shape even into that of an angel of light in order to accomplish their purposes. They seem to possess the art of enlisting and marshalling all the passions, prejudices, vices - in a word, all that is wrong in human nature, against all good. They vary their means according to their Subjects. Their leaven is at work in various shapes and ways among us." ${ }^{\prime 5}$

Morse could not collapse the issues that dominated the day any further; it was a battle between "all that is wrong ... against all good." The enemy was all-powerful and possessed of the talent to change shape and adapt their means to fit the situation. He also connected the contemporary religious and political conflicts with the greatest battle of all, that between God and the Devil.

In this great conflict Morse saw war with France as a means of clarifying the domestic situation. War, he believed, would make it possible "to distinguish more decidedly between friends and foes among ourselves." He also thought that in a wartime atmosphere the government would have "energy enough ... to silence and if necessary to exterminate its obstinate and dangerous enemies." Indeed, Morse occasionally hinted that violence 
was an appropriate means for handling dissent. While he was in Philadelphia in the spring of 1799 , he heard that William Duane of the Aurora had been "handsomely whipped" by army officers who demanded that Duane reveal the author of a piece critical of the army. Morse allowed that "such methods of obtaining satisfaction cannot meet the approbation of peaceable citizens and yet it is difficult to devise other methods of deterring such fellows [dissenting editors] from such scandalous abuse." Given Morse's problems with newspaper editors and unnamed sources, this reaction is perhaps understandable. Yet it also shows that Morse was capable of flirting with violence as a weapon against those who opposed the government. ${ }^{46}$

By 1800 , the man who, ten years earlier, had seen such great hope in the Constitution, in the nation's future and in his own prospects, was close to advocating violence against newspaper editors. His sense of hopelessness grew as the turn of the century loomed. He wrote his friends and correspondents that "no human means" would prevent Jacobin rule. He was convinced that America would be "left of heaven to run the aweful [sic] Revolutionary round which Geneva, Holland, Switzerland have done before us." This punishment was, Morse thought, the will of God brought down on America "for our gross abuse of our civil blessings and the privileges of the Gospel." He was braced and ready for the apocalypse. ${ }^{47}$

Or was he? At the same time Morse was predicting to one set of correspondents something akin to the end of decency and order, he was busy making plans and deals. At one level, essentially public and dramatic, Morse predicted ruin and handed America over into the hands of Providence. At another level, essentially private and pragmatic, he dealt with the situation very differently. Without ever admitting he was wrong about the Illuminati, he largely gave up on the issue. He did not, however, give up the notion that he should be a moral steward in the new Republic. He began to make a subtle but important adjustment to lessons learned in the Illuminati furor. From 1800 onward, he would become less and less the political figure and more and more concerned with religion. 


\section{5. \\ The Two-Layered Life}

In the life of Jedidiah Morse, the years between 1800 and 1819 have a clear unity. The end of the eighteenth century marked the failure of his embarrassing Illuminati crusade, the rise of the Jeffersonians to power, and the end of Federalist dominance at the national level. Morse had sought a role in national affairs using his connections with the federal government, especially his relationship with Wolcott. When splits in the Federalist party and the Jeffersonian victory in 1800 washed these connections away, Morse turned increasingly to New England issues, and especially those involving religion. As a public figure he emphasized the theme that had grown more important toward the end of the 1790s: the need to defend and preserve the past - the New England past-against innovation and change. During these years he strove for clarity, for a total vision; he wished to mark off the innovators from the orthodox, the sinners from the saved, and the selfish from the self-sacrificing.

Yet during the same years, there was another Morse beneath his rhetoric. Despite his profuse condemnations of greed and self-seeking, he pursued monetary gain with unabated zeal. In the two decades after 1800 , Morse's reputation as a minister more devoted to his career as geographer and author and the wealth it brought him grew. Inevitably the two sides of Morse came together. His liberal enemies in the Boston area undercut his crusade against religious liberalism by pointing to his capitalist behavior. Elements in his congregation persistently objected to his outside activities. In time large numbers left to create new churches and, in 1819, the remnant dismissed him from his pastorate. This was a shocking and depressing end to thirty years in Charlestown, years that had begun with such euphoria in 1789. Morse and his family literally retreated from Charlestown to New Haven, where Morse spent the last years of his life.

The political conflicts that dominated American life at the turn of the century spawned anguish in Morse's mind. The growth of the Jeffersonians alarmed him, but the bitter splits among Federalists bothered him almost as much. As relations with France worsened in 1798 and 1799, Morse adopted the prowar stance of the Hamiltonian wing of the Federalists. In June 1799, he wrote Wolcott that peace with France would be a disaster and that he was "infinitely more afraid of their [French] principles than their arms - and peace would open a wide door to the former which have already done us incalculable injury." Yet Morse found it difficult to side 
with Hamilton against Adams. When Hamilton circulated his attack on Adams's character, Morse wrote Wolcott that Hamilton was making a bad situation worse; the vicious attack on Adams, Morse thought, would "administer oil rather than water to the fire."

Morse was in a difficult position. Wolcott, his patron in the administration, was retiring, and by supporting Hamilton Morse was put in the uncomf ortable position of opposing the president. On several occasions he voiced his opposition to Adams's intention to make peace with France, yet on May 23, 1800, he wrote the president: "If anything can save us from calamitous Revolution, I sincerely believe it must be that course of policy you are now so firmly pursuing, which I earnestly pray GOD may succeed in saving our otherwise sinking Republic."2

Morse rarely experienced a dilemma for which he did not perceive a solution. The divisions among the Federalists spurred him to join Timothy Dwight in founding the New England Palladium. During his annual vacation trip in the autumn of 1800 , Dwight stayed at Morse's home for a week, and in this period the two hatched the plan to found the newspaper. Certainly the paper was designed to battle "Jacobinism" and Jeffersonianism, but Morse also hoped it would help unify the Federalists. He begged Wolcott to help bring federal patronage to the new paper and added: "None can more deeply lament the cause of the division among the Federalists than I do-and I have my fears that it has become impossible to heal it. What is best to be done in existing circumstances is difficult to determine. I had hoped that there was some middle ground on which the two divisions might meet with a good degree of cordiality and it has been wished that the Palladium might be the instrument of effecting and cherishing this union."

The Palladium had a stormy beginning. Financed by a number of wealthy and influential Federalists, Dwight and Morse purchased the Massacbusetts Mercury and New-England Palladium and installed Warren Dutton, a recent Yale graduate, as editor. The Jeffersonian press responded to the new paper with violent denunciations that focused on the apparent union of religion, politics, and journalism. When the opposing papers discovered that free copies of the paper were being sent to every clergyman in New England, the protests intensified. Clearly, the Palladium sought to provide political material for New England ministers to use in their sermons. Boston's Independent Cbronicle concluded that "the Union of Church and State is the Palladium on which they rest." The paper did not support itself, and after Dutton resigned in 1803, it came under new management. For Morse, his involvement with the enterprise may have soured him for good on political involvement. From 1802 until late in his life, Morse had little to say on national political issues; he would spend his energies, between 1802 and the early 1820s, on crusades directed toward saving New England from the spirit of change. ${ }^{4}$ 
While Morse, in founding the Palladium, struggled to heal the troubling splits in the Federalist party, he also saw his labors as part of the battle against the Jeffersonians. Morse's dismay at Jefferson's election had many roots; Jefferson was a southern slave owner and Morse's geographies were clear on this score. The South and slavery equaled immorality. More important, however, were Jefferson's religious views. He wrote his father that neither Jefferson nor Burr "are Believers in the Christian Religion," and that "for a Christian people to be governed by their own choice by professed Infidels is indeed shocking." When the deadlock between Jefferson and Burr developed, Morse supported Burr because he "is hated by the Jacobins" [one is known by his enemies?] and Burr would have to curry Federalist support "and the government will proceed in its former course." Morse also liked Burr because he "is descended from New England and very pious ancestors ... he is the son of many prayers and he may turn about and become a good man." Where one found New England roots and just the hint of New England religion, apparently there was a chance of reformation. ${ }^{5}$

To dwell on the anxieties about the splits among the Federalists and Jefferson's victory would paint a false picture of Morse's state of mind in the first years of the new century. He would of ten respond to specific events, but he also habitually lumped events into a generalized portraitone of ten dominated by visions of conspiracy. In a letter to an English correspondent, Morse articulated this general vision and laid out themes that would be part of his thought and action for twenty years. For him, the United States was suffering for its sins. Political and social disaster was "a just punishment for our sins-for our gross abuse of our civil blessings and the privilege of the Gospel." The punishment would take the form of "at least a temporary reign of Jacobinism in this country." The Jacobins, Morse argued, proceeded by flattering the people, by using "artful lies and insinuations," and "by blackening the reputations of good men and misrepresenting the measures of government." The rise of Jacobinism, which Morse linked to "the wonderful increase of licentious principles and conduct," had completely destroyed any hope Morse had for the political future of the nation.

This, however, was not all. Religiously, the nation was also in peril; there was clear evidence that Americans were abandoning "the Doctrines of Justification by Grace" [the keystone of Calvinist orthodoxy], and if one gave this up, one "must renounce the essence of the Gospel." For Morse, nothing less than true Christianity was threatened. In some ways, however, Morse was hopeful; he believed that "a goodly number" of the clergy still prof essed "the doctrines of grace" and that most churches still adhered to orthodox beliefs. Furthermore, revivals had begun in many parts of the country and "the good work is increasing." The clergy were still "decided and able friends of the government"; the colleges were flour- 
ishing and they sided "warmly in favour of the measures of the administration and of the Christian religion." In short, Morse conveyed a sense that important agencies of social control were still functioning and were still capable of producing a grateful and deferential people. However, he concluded ominously, "a preparation work has commenced and is visible in progress to corrupt our excellent Institutions and to mar and destroy those habits and morals, which by the blessing of God, they have produced." 6

Possessed by this gloomy vision, Morse increasingly looked for ways to separate and spare New England from the clutches of the conspiracy. $\mathrm{He}$ took to ending letters full of dark predications with "All I can say isGOD save our New England." By 1803, Morse, alarmed especially by the Louisiana Purchase, was willing to discuss the separation of New England from the Union. He confided to William Plummer that he had long considered the creation of a distinct New England nation as "indispensable to the preservation of our dearest interest." The acquisition of Louisiana would, Morse believed, hasten the split. The New England states could easily and peaceably leave the Union and establish a separate government "under the present Constitution, without the amendments which have been made since its adoption." These were radical views that illustrate the degree to which he saw New England as unique and possessed of superior institutions. His goal in urging separation was to keep the saints and sinners apart: "Connected as we now are with-I will not say what-I fear we shall be by degrees, drawn into a vortex in which our [New England] Institutions and the principles and habits which are their fruits and which are our glory and happiness will be engulfed and lost."

It was not long before Morse's vision of New England under a shadow of advancing conspiracy took more tangible form. The issue was the appointment of a divinity professor at Harvard; the professorship had been vacant since August 1803, when David Tappan, Morse's close friend, had died. It remained unfilled because of a barely repressed conflict within the Harvard administration over the nature of the replacement. Liberals wished to appoint a man of their sentiments; they were opposed by Joseph Willard, the college's president, and Eliphalet Pearson, professor of Hebrew and a member of the Harvard Corporation. Willard's death in September 1804 opened the way for liberals to begin a push for their candidate, Henry Ware. The passing of Willard also increased the drama of the occasion - the office of president was now also vacant.

The process whereby Harvard selected replacements for Williard and Tappan marked the beginning of the end of Congregational unity. The controversy at Harvard made public the growing split between orthodox Calvinists and Unitarians. The resulting hard feeling festered for a decade after 1805 until the Congregational church could no longer stand the 
strain. It was not, however, a clear-cut conflict within the college between two groups with differing theological views. Eliphalet Pearson, for example, very much wished to be president himself and there was ample evidence that his orthodoxy was far from sincere and deeply held. Personal ambitions and animosities may have played a larger role than theological principles. However petty and insincere the wrangling may have been, the controversy was an important step in the dramatic transformation of Harvard College. By electing liberals to the post of professor of divinity and also to the presidency, Harvard moved away from a reliance on rigid creeds as a test for professors. The college became more modern in the sense that it began to reflect the growing diversity of American religious culture. Men like Jedidiah Morse wished Harvard professors (and Congregational ministers) to be compelled to support a written creed such as the Westminster Confession. Men like Henry Ware were simply more open to diverse opinions and a somewhat open-ended definition of Protestant Christianity. Ware had made his peace with increased religious pluralism; he sought peace among the increasing number of Christian factions. No such peace was possible for Jedidiah Morse. For him such a peace constituted a betrayal of the past and the ideal of a revealed Truth, singular and indivisible. ${ }^{8}$

The campaign by the liberals greatly alarmed Morse. Harvard lay near the heart of Morse's vision of New England. It was an institution that helped create the habits he had celebrated in his geographies. That Morse saw Harvard as a bastion of orthodoxy is more than a little strange. He must have sensed that, Willard and Pearson excepted, the college routinely graduated men of decidedly liberal religious views. Certainly by 1804, the religious differences between liberal and orthodox Congregationalists were far from clear. Dimly, Morse perceived that "things are tending to schism in the congregational interest." His vision of wholeness and unity that he projected on to the New England past was jeopardized by the reality of open conflict at Harvard. The Harvard conflict also gave Morse a chance to stand and be counted. To him, the struggle proved that "dangers indeed thicken around us on every side. . . It is no easy matter to rouse men who are devoted to the acquisition or the enjoyment of wealth. ... Such is the case with too many of our patriots. What I can do shall be done."

Morse vaguely understood that the Harvard controversy pitted two sharply opposed intellectual visions. What, after all, was a professor? Thomas Hollis, an English Baptist who had endowed the divinity professorship, had stipulated that the professor be a man of orthodox views. In his pamphlet on the controversy, Morse essentially argued that "orthodox" meant "Calvinist." The core of Morse's view was his insistence that the 
present must conform to the past. For him, Harvard was an institution devoted to the preservation of the New England past and, particularly, its religious orthodoxy. Morse understood, perhaps more clearly than the liberals, that the very idea of a professor was undergoing change. He argued strenuously against "the fashionable opinion" that professors should not reveal their views on religious issues but should simply present all sides and let the students decide. If this were the case then, "on this plan, a learned Unbeliever in the Christian revelation, would make the most unexceptionable Divinity Professor in a college, as being most free from prejudice." He thought this was a crucial point. A college, especially Harvard College, was in part, at least, a social agency responsible for maintaining the purity and rigor of an orthodoxy rooted deeply in the past. Ware's eventual appointment meant that "the faith of our churches should become less pure, their discipline less strict, the standard of Christian morality lowered the difference between those who professedly serve God, and those who avowedly serve him not; till at length the spirit and power of our religion shall have evaporated, and its very forms be abolished. For Christ and the $\mathrm{CHURCH}$ was this ancient College founded by men we delight to call our Fathers. ... Oh may the God of our Fathers, who still lives and reigns, in mercy preserve it, so long as the sun and the moon shall endure." 10

This statement illustrated Morse's major goals after 1800: maintain the purity of "orthodoxy" and clarify the difference between the true servants of God and "those who avowedly serve him not." It also exhibited the connection between Morse's commitment to orthodoxy and his patriarchal feelings, as he often linked orthodoxy and its institutions to reverence for the father.

The Harvard dispute firmly established Morse as an open defender of orthodox religion. He had rarely pursued the issue in the fifteen years he had resided in Charlestown because he sought unity in the Congregational church and because, since 1793, the nation had been so severely threatened by European powers and internal political disputes. ${ }^{11}$ The bitter debate at Harvard in 1805 marked a turning point in Morse's attitude; from that point onward he openly advocated religious orthodoxy and sought to establish clear lines between the orthodox and the liberal. Prior to 1804, Morse envisioned the perfect community as of one mind politically, socially, and religiously. After the Harvard controversy he was content to focus on the task of establishing, within the larger community, a homogeneous religious community of believers in evangelical truth.

In his attempt to bring his community into being, Morse became one of the founders and the first editor of the Panoplist. One of the first special interest periodicals in America, the Panoplist consciously sought to create a community out of those with orthodox religious views who sought what 
the magazine called "Evangelical Truth." Morse saw the magazine as part of a wide-ranging war with a shadowy enemy Morse had once called Jacobinism. By 1805 , the enemy had become Unitarianism. In June 1805, just as he was completing the first issue of the Panoplist, he wrote the Reverend Joseph Lyman that he foresaw a conflict between the Panoplist and the Christian Monitor, a magazine Morse believed would advocate Unitarian beliefs. Morse argued, "I consider Unitarianism as the democracy of Christianity. It dissolves all the bonds of Christian union and deprives religion of all its efficacy and influence upon Society. Our ecclesiastical affairs are fast assuming the portentous aspect and convulsed state of our political affairs."12

What many saw as a religious and political dispute between well-meaning individuals, Morse saw as war. His enemies were tireless, duplicitous, and evil. Magazines had become weapons in a conflict fought with words. In the preface to the first volume of the Panoplist, Morse paid tribute to the power of magazines. For him, the periodicals on the other side were "conducted by unprincipled and designing men," whereas the orthodox journals were produced by "the wise and good"; one type spread "poison," the other the "antidote." The poison in this case was "a specious and subtle philosophy" born in Europe and now ready to engage in "portentous warfare" with Christian truth in America. ${ }^{13}$ Morse's literary images reveal, to some degree, the core of his public life during the first two decades of the nineteenth century. He routinely used the images of "war" and "sleep." The choice of "Panoplist" as the title of his magazine reflected his desire to conjure a warlike atmosphere. These images have a direct relationship with Morse's desire to see himself as a proper Christian soldier-alert, wakeful, militant, ready. Morse often warned the public about the dangers of "sleep." As America slept, a shadowy enemy army crept across the border and insidiously spread a poison that weakened the nation's ability to fight.

There were connections between the Morse who edited the Panoplist and the Morse who crusaded against the Illuminati. The creation of a duplicitous enemy (Jacobinism/Unitarianism), the warlike metaphors, the vague connection of "the enemy" with Europe, and the desire to protect values associated with the American past all appear in both crusades. What factor, for Morse, had created the opening for the pernicious ideas of the Illuminati and the Unitarians? In both cases it was "prosperity." Unitarianism and Illuminism both relied on the effects of economic wellbeing to weaken the body politic and prepare it for the invasion. In 1805, Morse claimed that "peace and outward prosperity put the church ... in imminent danger." "Carnal security" and "worldly ease and affluence" put men to sleep while "the ever wakeful and busy enemy sows his tares." Prosperity, in addition to inducing sleep, "corrupts the heart, and warps the understanding, and prepares the way for a dislike, hatred, and rejec- 
tion of the pure and humbling doctrines of the gospel." The religion of men drugged by prosperity was a mild and rational faith adapted to their vitiated tastes; it combined "the service of God and Mammon." Morse wrote this.during the most prosperous period of his life and, as we shall see, at the beginning of the period when his congregation and others would severely criticize him for neglecting his religious duties and for his pursuit of wealth. ${ }^{14}$

The Panoplist and Morse were vague about the nature of their enemy and equally foggy about their own creed. Morse wrote in the first issue that the editors "explicitly avow their firm adherence, generally and for substance to what have been called the Doctrines of the Reformation." These doctrines were, Morse claimed, the essence of the creed followed by the Church of England, the Presbyterian church and "the great body of the New England churches." This faith was, the Panoplist contended, the theology "of our venerable forefathers." This amounts to a truly remarkable attempt to rewrite history. By lumping together the Church of England, the churches of New England, and New England forefathers, Morse conveniently forgot deep religious conflicts that had certainly enlivened the seventeenth and eighteenth centuries. ${ }^{15}$

How can we account for this remarkable act of forgetfulness? The need to create comforting myths was certainly active in Morse. He, however, had other more practical pressures on him as he began the Panoplist. Any attempt to unite the orthodox in New England had to confront the fact that among those who clung to some form of Calvinism deep divisions also existed. Morse labeled "the congregational clergy in New England" Calvinistic. Among this group there were "severe" Calvinists who followed Calvin himself, Jonathan Edwards, and Samuel Hopkins. In contrast to the "severe" Calvinists was a "mild" faction who followed Doddridge and Baxter. Taken together, the two groups, Morse thought, made up 95 percent of the clergy in Connecticut, western Massachusetts, Vermont, New Hampshire, and Maine. One goal of the Panoplist was to unite these two groups under one banner and to fight as one the liberal challenge to orthodoxy. The "severe" group, or Hopkinsians, were suspicious of moderate Calvinists such as Morse, and were reluctant to make common cause. They had established their own periodical, the Massacbusetts Missionary Magazine. In editing the Panoplist, Morse kept the theology foggy enough to lure the Hopkinsians into a merger and, in the spring of 1808 , he succeeded when the two monthlies blended into one. ${ }^{16}$

The moderate Calvinists could also be cranky, and Morse spent much of his time quieting the suspicions of both sides. Even one of Morse's closest friends, Abiel Holmes, complained when he found Hopkinsian doctrine in the Panoplist. He wrote Morse that one of the essays in a recent issue was "exceptionable": "It is pure, unadultered Hopkinsianism which, 
it is alleged, was not to have a place in this work. If the tenets of the Old School [moderate Calvinism] are made to give place to those of the New [Hopkinsian] - the disciples of the Old School will desert the standard."17 Unlike Holmes, Morse's commitment was not to a school, but to unity. The orthodox must come together and fight the insidious liberalism that wrapped its hand so firmly around Harvard and threatened the sound values of the New England past.

The Panoplist, under Morse's editorial hand, exhibited a full-blown dualistic view of the world. He muffled fine theological issues by using "true Christians," "the Gospel," and "the faith once delivered to the saints" as code words for readers to define as they liked. The magazine assumed a conspiracy existed against true religion and decency, and apparently so did many readers; the monthly became one of the most widely read publications in New England. The Panoplist, in a number of ways, helped create the "evangelical community." It established for this community a body of "saints," by printing endless biographies of orthodox theologians. The first issue, for example, contained a long account of the life of David Tappan, the Harvard professor. Biography and autobiography served to instill a vision of the orthodox life and the correct way to salvation. Sermons and reviews of sermons were common fare, as were news of ministerial and missionary societies. Each issue also had its share of arcania, tidbits from the evangelical world. For example, one edition reported on the Bibles in the library of the Elector of Wartemberg. There were, amazingly, four thousand editions, including three in "Greenlandick," six in "Hindoostanee," and thirteen in "Tamulick." 18

The evangelical community that took shape in the Panoplist contained a substantially new role for the minister. The older definition of the minister as the moral and spiritual guardian of a small flock had clearly given way to a new definition that gave the minister larger and more generalized responsibilities. Ministering was becoming a worldwide endeavor, concerned with foreign missions, state ministerial associations, the creation of state and national Christian revivals, and the editing of evangelical journals. Morse and the Panoplist understood that this new role for the minister brought the divine face to face with the realities of the world. In a remarkable essay that blended Morse's views and some lines identified as "from Massillon," the Panoplist attempted to portray "The Spirit of the Ministry." The fundamental duty of the minister was "to exhort, to correct, to reprove." This required "an heroick disposition" that elevated him "above everything which influences the conduct of other men." This spirit was "very much opposed to the spirit of the world, for the spirit of the world is a temporising spirit." In the world men must be ready to "think always with the greatest number" to be agreeable; to be ready "to smile at 
impiety." The ministers, "who ought to be censors of the world," must stand as soldiers against the tide of spiritual compromise and moral laziness. The price of such militancy will be a reputation as rigid and unsocial, the "influential" will withdraw their approval from such a minister. The Panoplist vision of the minister had little room for Christian love and forgiveness. Instead, forgiveness, meekness, and caring had become signs of a fatal compromise with "the world." The Christian minister must be a soldier, standing firm, censoring, reproving and correcting a world gone bad. ${ }^{19}$

To create such ministers required a new kind of theological seminary and, between 1805 and 1808, Morse successfully helped create such a place. Depressed by the liberal victory at Harvard, Morse quickly turned to planning "a Theological Academy at Andover." As these plans slowly developed, Morse learned that the Hopkinsians, led by Gardiner Spring, were of the same mind. As with the Panoplist, Morse feared division and sought union. In this he had a strong partner in Leonard Woods, who told Morse that in creating an orthodox seminary, "heaven has placed you in the front of the battle against the powers of error and wickedness. The Lord support and guide you, and give you victory. If we can only get all calvinists together, we need not fear. Hopkinsians must come down, and moderate men must come up, till they meet. Then the host will be mighty."20

Morse and Woods received crucial help from Samuel Abbott. A wealthy Boston merchant, Abbott had withdrawn a large bequest to Harvard after the controversy and had transferred his money to Phillips Academy. The money was to be used to support a theology professor of sound Calvinist principles. Morse had been a trustee at Phillips since 1795 and was sure of its commitment to teach orthodox piety. In July 1806, a group met to draw up plans for the seminary. Morse's goal was clear: "It was thought wise and prudent to lay the foundation of the institution on so broad a scale, as to embrace ... all shades of Calvinists - or all who approve the Assembly's Catechism or the Doctrines of the Reformation, in hope that time and friendly intercourse and discussion would bring all together on some middle ground. With these views it was intended that the Professors should be selected from several shades so that the confidence of each might be secured by equal representation." 21

At this point, however, Morse became alarmed by news that Spring and the Hopkinsians were planning to create their own seminary supported by their own benefactor, William Bartlett. The Hopkinsians felt that in the long run, they would have to make too many theological compromises if they blended their resources with the moderates at Andover. Morse did all in his power to convince the Hopkinsians that two orthodox seminaries would only help the liberals. $\mathrm{He}$ argued that the differences among the orthodox were not fundamental and that union against heresy 
was essential. It was not Morse, but Woods who was most afflicted by the conflict; attracted to both Spring and Morse, he eventually sided with Morse and union. Woods shared Morse's deep desire for unity, and it was Woods who ultimately convinced Spring, and also convinced the Andover benefactor, Abbott, that the moderates could live peacefully with the Hopkinsians. The birth of Andover Seminary was possible only because men like Morse and Woods were able to convince the distrusting and suspicious in both orthodox camps that union could be achieved without either side giving up its theological principles. ${ }^{22}$

Yet it was not entirely clear that Morse held his theological principles in the same way that Hopkinsians did. The compromise that brought the moderates and Hopkinsians together at Andover hardly looks like a compromise at all. In the negotiations that led to the blending of the moderates with the New Divinity forces, key differences emerged. The moderates wrote what was essentially a charter for the new institution with doctrinal requirements under which professors at Andover were to perform their duties. This charter, or constitution, made clear what the professors must oppose, but left what they should advocate vague. The list of enemies included everyone from Jews to Socinians, from Aryans to Universalists. Their positive theological platform was the Scriptures and the Westminster Assembly's shorter catechism. This constitution reflected the diversity among the moderates; anyone with Calvinist learnings could have signed it.

In March 1808, the Hopkinsians produced their doctrinal platform, usually called the Associate Statutes. This document presented a rigidly Calvinist set of requirements and a system of visitations to insure that the new seminary did not fall away from the strict New Divinity theology. The statutes were designed to guarantee that the other moderates put up almost no resistance to the Hopkinsian demands. The moderates were certainly less united and less interested in theology and clearly more pragmatic. The moderates knew that by uniting the endowments from both sides of the Calvinists camp, the seminary would start its life on very sound financial footing.

There is another way of looking at the behavior of the moderates and of Jedidiah Morse. The Hopkinsians were devoted to the theological debate. They wished to be intellectually honest and to defend, without compromise, the doctrines of Calvinism (divine sovereignty and human depravity) against the inroads of liberalism. The moderates, because they evaded discussion of the "harder" doctrines of Calvinism, were occasionally targets of New Divinity criticism, which characterized moderate Calvinism as little more than disguised Arminianism. Moderates, like Morse, had little interest in doctrinal debate, but a keen interest in saving what they 
often called the "orthodox interest." Gradually throughout the late eighteenth century they had compromised; they had softened the hard edges of Calvinism in order to keep as many within the orthodox fold as possible. In so doing they gave off the subtle signs of Puritan tribalism. The moderate Calvinists were devoted to the establishment of clear lines between not very clearly defined groups. By 1808 , Morse, as we have seen, was much clearer on the identity of the unregenerate, the wicked, than he was on the identity of the saved. The Hopkinsians may have been cranky, even obstinate, but they were clearly in the tribe. By establishing Andover, Morse was motivated by a desire to gather the faithful (no matter how poorly defined) and establish a tribal stronghold against the gathering forces of secularism, fragmentation, and change. ${ }^{23}$

On September 28, 1808, Morse was triumphant. The new seminary opened with a ceremony in which Morse played a prominent part. The Panoplist commented that "the auspicious commencement of an Institution, so important to the interest of religion and our country, will, we hope, prove a bright morning of a prosperous day." The morning was all the brighter because the negotiations for the seminary had also cleared the way for the union of the Panoplist and the Hopkinsian Massacbusetts Missionary Magazine. Depressed after the Harvard controversy, for three years Morse had sought union among the orthodox; in the autumn of 1808 , it had come to pass. ${ }^{24}$

By 1810, Jedidiah Morse had become, in the New England mind, one of the most prominent spokesmen for "union and love." Yet it was a peculiar type of union and love he sought. It made little sense given the corresponding desire to distinguish himself and his allies from the liberals, who also continued to identify themselves as Christians. The "union and love" that Morse helped create through the Panoplist and Andover was exclusive, not inclusive. In his actions there was more than a hint of tribalism. Ultimately the evangelical community that emerged was defined as much by what and who it excluded than by what it professed as truth.

In other aspects of his life between 1800 and 1819, Morse exhibited this same desire to exclude and clarify, to separate the sinners from the saints. He was active in a number of ministerial associations and benevolent societies that pursued evangelical goals. He also played a crucial role in bringing about the formal division of the Congregational church into orthodox and Unitarian groups. In this too, his goal was to separate, clarify and divide.

Morse began the new century with a missionary trip to the Isles of Shoals off the coast of New Hampshire. He took the trip as an agent for the Society for Propagating the Gospel Among the Indians. This society, founded in 1787, hardly addressed the Indians at all; instead it focused its 
efforts on the District of Maine and sites such as the Isles of Shoals. Implicit in their efforts was a fear of lawlessness and moral degeneration on the New England frontier. Morse joined the society in 1792 and became assistant secretary in 1795 .

The trip to the Isles of Shoals revealed much about the motivations behind Morse's missionary activity. He saw himself as the agent of New England order and stability sojourning among the lost and wretched. The people were badly clothed and fed; they were in virtual bondage to the few property owners who controlled all the labor and wages. They were all, "with few exceptions, addicted in a greater or less degree to profanity and intemperance." The institution of marriage had fallen on bad times and Morse found a number of people living together in sin. Morse performed a large multiple-couple wedding ceremony in the hope that it would improve the image of marriage among the population. The participants in the ceremony Morse described as "people without civil laws and in a state of nature." In his report to the society, Morse wrote that the islands were important as a port for ships in distress and valuable because of the abundant fish in the area. His only recommendation was that "a kind of Patriarch" be sent "to maintain order among them." He did not suggest a minister, he wrote "Patriarch," which was of ten his solution for disorder and moral laxity. In fathers he had great faith. ${ }^{25}$

With endless zeal Morse helped father a number of organizations that sought to do good. He was one of the founders, in 1803, of the Massachusetts Society for Promoting Christian Knowledge, which sent thousands of religious tracts into the frontier. In 1814, the American Tract Society was founded at Andover and Morse served this group as vice-president and chairman of the Executive Committee. He served local societies that sought to print and distribute Bibles and, in 1816, he was involved in the establishment of the American Bible Society in New York City. In 1813, he was the central figure in the establishment of the Charlestown Association for the Reformation of Morals. He was at the center of an outburst of organizing activity. These organizations have been much debated. Did they reflect republican values and true Christian piety, or were they conservative attempts to reestablish social control in an expansive and increasingly secular nation ${ }^{26}$ They were, beyond doubt, aimed at what men like Morse perceived as an enormous problem, and their rhetoric emphasized the scope of their evangelical dreams. These organizations sought to solve nothing less than the nation's moral, educational, and religious problems. Morse shared in, and gave voice to, these grandiose dreams; in 1814 he, Lyman Beecher, and Jeremiah Evarts issued an address for the Education Society at Yale. The plea focused on the dearth of ministers in the American West and issued a call for an enormous national effort by "all the pi- 
ous and well-disposed part of the nation" to unite in "this work of selfpreservation": "The evangelizing of the nation must not be a secondary object to any one. It must stand forth in all its magnitude, as the prominent object upon which all eyes are fixed; for which all hearts beat, and in which all hands are employed. A Bible for every family, a school for every district, and a pastor for every 1000 souls, must be the motto upon the standard, round which the millions who enjoy these blessings must rally for the purpose of extending them to those who do not."27

This enormous effort to provide a common religion for Americans reflected an acceptance of political divisions. Morse, and the other authors of the address, assumed that correct Christian instruction and a common education could "produce a sameness of views, and feelings, and interest, which would lay the foundation of our empire on a rock. Religion is the central attraction which must supply the deficiency of political affinity and interest." With the Federalist party in decline and disarray, Morse, and others like him, found the source of a peaceful and homogeneous society in a massive religious and educational crusade. This effort had local elements, but its ultimate thrust was national and utopian; its goal was nothing less than redemption of the nation from conflict and disunity. ${ }^{28}$

Morse's emphasis on stability and unity was also a central element of his involvement with blacks. Morse's nineteenth-century biographer reported that on a night in 1802 Morse heard blacks fighting in the streets outside his home, apparently sparking a desire to help the blacks of Charlestown. He understood that their behavior was the product of neglect; denied education and religious instruction, blacks had become a "problem." Quickly, the reformer Morse set about solving it: he began a Sunday lecture program, in 1803 he helped start a school for black children, and in 1805 he was involved in the creation of a church for Boston-area blacks. Finally, he worked to further the colonization movement. In league with Paul Cuffee, a black shipowner, Morse sought blacks willing to return to Sierra Leone. ${ }^{29}$

Perceiving him as a friend, blacks asked him to deliver an oration at the Boston-area celebration of the end of the slave trade. It was one of Morse's most revealing works; it illustrated that beneath Morse's reform efforts lay a profound love of order, stability, and a hierarchical society. He took pains to instruct those assembled on the true meaning of "freedom and equality." These ideas should not be "so construed, as to militate with that order and subordination in society, which is indispensable to its peace, nay to its very existence." Reflecting his faith in the singsong tones of the catechism, Morse put the idea in poetic form: "Order is heaven's first law, and this confest/Some are and must be greater than the rest." ${ }^{30}$

To drive home this point, Morse employed the ancient comparison between human society and the human body: "Distinctions of rank and con- 
dition in life are requisite to the perfection of the social state. There must be rulers and subjects, masters and servants, rich and poor. The human body is not perfect without all its members, some of which are more honourable than others; so it is with the body politic. There is nevertheless a kind of equality among members: all are free; all are useful and necessary; all are regarded and honoured according to their station and use." ${ }^{31}$

Within this body politic there existed a diversity of men. Slaves, as a type, greatly interested Morse. Slavery was not the product of human cruelty and greed but the result of the fall of man, "strengthened by the wickedness which overspreads the world." Abolition, in this view, represented a sign of "returning health" to the human community. In this light slavery had indeed been beneficial; it was slavery that had transported millions of blacks "from the darkness of paganism to a christian land." Slavery was an essential part of the divine plan by which the whole world would be Christianized. Morse also diminished the horrors of slavery by comparing them with "the slavery of sin," which was "beyond all comparison worse than any conceivable state of earthly bondage."

Morse sought to dampen any notions the blacks in attendance may have entertained that freedom meant freedom. In his conclusion, he told his listeners that freedom should never be "a cloke for licentiousness." Many were watching, and the black man and woman had to show that they were "worthy to be free." Morse's final words were, "Be contented in the humble station in which province has placed you. ... Be particularly on your guard against excess in the joys and festivities of this day." 32

These words spoken in the African Meeting-House to an assemblage of blacks revealed important aspects of Morse's reform motivations. The desire to help blacks, to provide Bibles, tracts, and ministers, and to generally reform morals had its root in intellectual sources that go back far beyond the "French threat" of the 1790s, the election of the infidel Jefferson, and conflict with religious liberals. Morse, even as a college undergraduate, had divided the world into saved and damned, with the saved ministering hopefully to the damned. This notion blended easily with the idea of a hierarchical society, with religious and political fathers at the top and lesser types, enslaved by sin to some degree, spread out below. It was a beguiling and crucial myth in Morse's life. It resided regally at the very core of his geographies, his Illuminati sermons, his participation in the benevolent societies and reform groups of the early nineteenth century. It also resided, in Morse's mind, in the Connecticut countryside of his youth, where happy yeomen content in their stations rejected "licentiousness" and paid due deference to their religious and secular fathers.

It is not surprising that as Morse became involved in numerous national crusades he also found in Charlestown, by 1813 a rowdy seaport 
town, a community in need of reform. His discourse at the first meeting of the Charlestown Association for the Reformation of Morals clearly revealed the ancient roots of his reform motivations and his tendency toward tribalism. In the course of the talk, Morse listed a number of reasons for establishing a group to attack public lewdness, drunkenness, and Sabbath breaking. The group was one method to bring "the feminine influence" to bear on public behavior. Morse also cited English reform societies as an example (in the midst of the war!) that Americans should follow. His remarks, however, made it clear that the attack on immorality was dictated by the terms of the social covenant. In terms that John Winthrop would have understood, Morse argued that all communities have a covenant with God that calls for the people to combine their efforts against the influence of evil. For a community to survive and prosper, "the good people" must be bold and attack the evil-doers "in their strong holds and hunt them from their mighty and secret lurking places." Morse suggested that modern evil-doers were like the biblical Achans (an image he had employed in the Illuminati sermons), "the troublers of our Israel" who must be apprehended and punished so that the community might prosper. By living up to the covenant, the reformer clearly benefited. They would be like the Levites who rose up and fought, along with Moses, the makers of the golden calf. The Levites, after their heroic service, "procured the blessing of God, not only on themselves, but upon their whole tribe. Their heroic fidelity was a preparation to their appointment to the honorable and advantageous service of the sanctuary."

For Morse reform was, in part at least, an avenue to purity and the reconstitution of the tribe. The process of reform identified the pure and the impure, the godly and godless. Morse argued that the reformer could take comf ort from God's words in the prophecy of Ezekiel. The Lord had commanded that those in Jerusalem who had opposed evil be marked on the forehead so that the slaughter of the sinners might spare those marked. Morse saw a direct analogy between ancient Jerusalem and early-nineteenth-century Charlestown. .He argued that "pestilence" and "famine" were coming, and that "by our sincere mourning ... on account of the abominations which are done among us, and by our best exertions to put an end to them, we can obtain the mark on our foreheads or the evidence that we are on the Lord's side then shall we dwell safely and be quiet from fear of evil." Thus, for Jedidiah Morse reform became an act of purification. By conspicuously standing with the godly he could take on "the mark" of the pure. We surely are justified in asking: Why was the Reverend Morse in need of purification? ? $^{33}$

In short, there was another Jedidiah Morse. The zealous public man who sought to evangelize the nation, if not the world, coexisted with the 
private man who left rural Connecticut for cosmopolitan Boston, where he accumulated capital, speculated in land, published geographies, and neglected his duties to his church. Slowly his reputation as a duplicitous and insincere man grew; his congregation split and split again.

Between 1800 and 1819, as the public Jedidiah Morse triumphed in his various crusades, the private, or at least the less public, Morse suffered defeat after defeat. He was, in the eyes of his congregation, an inadequate pastor. As an author, he became entangled in a controversy with Hannah Adams that cost him much of his reputation as a gentleman and minister. Finally, his financial affairs became so complex and costly that the vast fortune he received from his book sales evaporated.

The relationship between Morse and his Charlestown parish was never a happy one. In 1796, he threatened to leave because of his low salary, but remained when the church paid him a special bonus of one hundred pounds. In 1799 and 1800, he thought seriously about moving to new pulpits in Exeter, New Hampshire, and New Jersey. Perhaps influenced by the embarrassment caused by his Illuminati crusade and opposition to him in the deeply politicized parish meetings, the lure of a new pulpit was strong. Morse was so serious about leaving Charlestown that he consulted his father about both opportunities. Deacon Morse firmly replied that any move that took him farther from Woodstock would make his parents unhappy. He wrote that "it is no Credit for a minister to remove from his people to another without some very Special \& Substantial reasons. It would not be very agreeable to your Parents to have you leave Charlestown and go to New Jersey, or any where farther from us, while we live; which in the Course of Nature cannot be much longer." ${ }^{34}$

The problems with his parish, and perhaps within his Church, did not go away, however. In November 1802, he asked his congregation to sever its relationship with him if certain problems could not be resolved. His address to the church was couched in the most veiled language. He referred to "past events" that had wounded his feelings and to "exertions" he had made that brought criticism down upon him. The situation was so bad that Morse saw no hope "of our ever uniting in any plan which will enable us faithfully and successfully to fulfil the duties we owe to ourselves as a church, or to those around us." 35

What did this mean? It meant that Morse was putting the pressure on the congregation to do something or let him leave. He had done something ("exertions") that had offended some in the church. It may have been his Illuminati sermons, his work on the Palladium, or something else. Finally, it meant that Morse felt he had the upper hand in the situation. He had friends within the congregation who, he knew, would support him, and he also knew that the church would be unwilling to endure the ex- 
pense of settling a new minister if Morse should leave. There is some evidence that Morse had another pulpit available if his challenge to his congregation went unanswered. The Reverend Peter Thacher of Boston's Brattle Street Church had died, and as Morse informed his father, Thacher's death "seemed to open a door for my removal." ${ }^{36}$

No matter what may have been at the root of Morse's request to dissolve his connection with Charlestown, it worked. His "friends" within the congregation set out to solve the conflicts that had troubled Morse's pastorate. They petitioned the General Court to incorporate the church, in effect to make it the parish and make only the church members responsible for the affairs of the church. As Morse reported to his father, the incorporation proposal "was most violently opposed by all the democrats both in town and in the Legislature." Despite this opposition, it became law on March 5, $1803 .^{37}$

Morse exulted in this victory. He was now free from the hold of the parish that was decidedly against him. He had described to his father the relationship he had endured with the parish and the great need for incorporation:

You can easily imagine the necessity of an incorporation when I tell you that all the inhabitants of the town-Baptist, Universalists and all ... have a legal right and actually have exercised their right to attend all parish meetings and vote all things which relate to me and parish matters. Though the Parish Treasury is supplied wholly from a tax on the pews in my meeting house. Yet those who attend the Baptist Meeting and attend Mr. Murray's and who go to no meeting no where have a right to come and vote that that money shall be expended in opposing the wishes of the pewholders-this they bave done! ! ${ }^{38}$

Incorporation, however, meant more than freedom from the parish. The new corporation immediately formed a committee to raise Morse's salary to the Boston-area average. The committee, chaired by Aaron Putnam, who owed Morse twelve thousand dollars, elevated Morse's weekly wage from eleven to twenty dollars. Morse also took some joy in the fact that those who opposed him were powerless to stop the incorporation and his generous wage increase. In fact, Morse probably never felt so sanguine about his position in Charlestown. The church was experiencing a revival of sorts, eighteen people had joined between December 1802 and May 1803. Morse's series of lectures to young people was attracting crowds of up to four hundred. In addition to these lectures, Morse also regularly spoke to "the Negroes" on Sunday evenings. His audience for these talks he described as "attentive, serious and grateful." His three sons were en- 
rolled at Phillips Academy, and Morse and his wife Elizabeth were doting on their new daughter, Elizabeth Ann. ${ }^{39}$

This nearly euphoric state elicited from Morse a most significant letter to his father. In the past, he had expressed his gratitude to his father, but in 1803 he added a new element. Morse gave his father money. Apparently people in the Woodstock area owed Jedidiah money, which they gave to Deacon Morse to send on to his son. On this occasion, the son wrote, "I pray you, Sir, to accept what is in your hands and expend it on such articles as will afford you comfort and most effectively alleviate the infirmities of age." Morse suggested that his father could count on his affluent son for more money in the future; it was repayment: "I feel great pleasure in reflecting that I have always loved and endeavored to obey you. For all your love and kindness towards me, for your care and expense in my education I most sincerely thank you. And since God has graciously preserved you to a good old age and prospered me in the world, most gladly would I contribute all in my power to render your old age comfortable. Whatever sums you may need for this purpose they will be at your command." ${ }^{40}$ Morse had discovered a partial answer to the nagging obligation (and the resulting sense of guilt) he owed his father: the answer was cash, and cash shall make you free.

Enveloped in a general euphoria, Morse felt "more satisfied and more settled and fixed than I have for ten years past." This feeling did not last long. His daughter, Elizabeth Ann, died in 1803. By the end of 1804 the Harvard controversy had begun and Morse began to fret about the fate of orthodoxy and New England's future. Equally troubling was rebellion within his congregation. After incorporating and raising Morse's salary, the congregation switched to a new method of raising money. Before incorporation the members of the church financed its operation by purchasing pews and paying a weekly pew tax of approximately twenty cents. After March 1803, the church raised money by levying a tax on the property of members. This new system generated a great deal of opposition. ${ }^{41}$

By January 1804, relations between Morse and his congregation had reached a crisis. A substantial number of wealthy and influential members of the congregation refused to pay the new property tax. The church was on the verge of resorting to lawsuits to collect the money for Morse's support. Beyond this explosive issue, Morse and the congregation were mired in general misunderstanding and distrust. The congregation objected to Morse's frequent journeys to deal with his business interests. More important, however, the contract in 1803 included a promise by Morse to give up "those literary employments which are foreign to the appropriate duties of my office." His writing for profit and his membership in a number of literary and religious organizations provoked violent 
objections from his congregation and was apparently one reason the new church tax was unpopular and unpaid. In short, they would not pay Morse's new, higher salary. ${ }^{42}$

The squabble in 1804 indicated the basic cause of the problems between Morse and his church. In 1793, the church had agreed to let Morse continue his writing as a way of making up for his admittedly low salary. It was this informal agreement that ended in 1803. Morse's sense of wellbeing after the new contract was signed may well have reflected a sense of release. He no longer had to live two lives: minister and author. By January 1804 , he had changed, however, because he had ready for the press new editions of most of his geographies and gazetteers. In 1804, new editions appeared of Elements of Geography (fifth), Geography Made Easy (ninth), and The American Gazetteer (second). Early in 1805, Morse published a new edition of the American Universal Geography (volume 1, the fifth; volume 2 , the fourth). The evidence suggests that in 1803 his congregation believed that Morse would give up his career as geographer; by January 1804 , it was clear he would not.

Certainly Morse possessed a confused sense of his own identity. Fond of the profits his books earned, he was also attracted to the idea he was a devoted parish minister who tended his flock with care and devotion. In January 1804, Morse confronted evidence that at least one influential member of his church thought that he neglected even the most basic religious duties of a minister. William Goodwin, son of the man from whom Morse had purchased some Maine land, wrote Morse that "a considerable majority" of the church opposed Morse and the solution was obvious: "If persecuted in one city flee to another." Goodwin, in effect, called Morse's bluff and invited him to leave Charlestown. He did not, however, mention geographies, journeys, or any of the other issues, except a brief reference to the controversy over the new property tax. Goodwin saw Morse as caring little for his congregation: "A people, Sir, at variance with their minister, cannot feel towards him as they ought, while that minister cares but little for them; and instead of becoming their religious teacher and friend, treats them with pointed neglect; casts them aside as the goats of the flock; fans the fire of opposition until it becomes a flame, and embarrasses religion with taxes which the most conscientious men refuse to pay thus tacitly counteracting the very platform of the church." ${ }^{43}$ Morse responded by ignoring the charges of neglect and demanding of Goodwin the names of those in the group opposed to him. Until they revealed themselves, Morse stated that "no further communications on this subject will be noticed." 44

Goodwin's charges may have been overblown, because Morse quickly reached a new settlement with his congregation; he accepted a salary cut 
and returned to publishing books. Relative peace reigned in the Charlestown church until 1808, when Morse again complained he was underpaid and his contract was renegotiated. Apparently he also promised, once again, to give up "business" unrelated to his parish duties. As in the past, conflict with his church spawned admonitions from his father. The deacon declared that he was happy to hear that peace had been restored between Morse and his congregation "and that you have determined to gratify your people in what was proposed and as fast and fully as possible lay aside those concerns which I think must greatly Impede and hinder your usefulness and Success in your high and holy Calling." He suggested that the time had come for his son to set aside business "and dwell on the great and Important duties of life." 45

Although relative peace existed in the church between 1804 and 1810, Morse continued to struggle with others in the town. The incorporation act of 1803 had angered a number of Charlestown citizens; their anger simmered until 1812, when they petitioned the General Court to repeal incorporation. The petition pointed out that incorporation had transferred ownership of the meetinghouse and its pews from the people as a whole to a small tribe of church members. Incorporation, in the petitioners' view, had, in fact, been a seizure of property (pews). Many in Charlestown were confronted with the choice of staying in church and paying a heavy property tax or giving up the pew for which they may have paid as much as two hundred and sixty dollars. Furthermore, the petition provided some sense of the size of the opposition against incorporation (and Morse?) in 1803. The petition claims that two votes were taken nine years earlier; the first, in "the Parish assembled in Town Meeting," was 114 to fiftyone. The second, in which "Christians of other denominations" voted, was 157 to eighty-eight. This tended to cast doubt on Morse's contention that members of other religions always voted in parish elections. In any event, the petitioners in 1812 claimed that in both votes the majority was against incorporation. ${ }^{46}$ Only an effort of the imagination can grasp the impact of this incessant conflict on Jedidiah Morse. His character and worth as a minister were a constant topic of town gossip. The incorporation issue, which simmered for nearly a decade, was only the focus for a general discussion of pastor Morse and his role in the town.

There seems little doubt that, between 1800 and 1819, Morse worked as a minister in a church and town that harbored a growing dislike for him and that provided him little, if any, sense that he was fulfilling the ancient duty to guide his flock in peace and harmony. The most decisive evidence of this came from one of Morse's longtime supporters. By 1814, Morse was fully engaged in the war against liberalism and in a long list of reform and ministerial societies, yet Deacon Issac Warren criticized Morse 
not only for his involvement in these activities but also for neglecting his congregation. Warren, in his letter to Morse, described himself as "ardently attached to Dr. Morse" and as one who had defended his pastor "against malignant aspersions." The deacon, however, could no longer defend Morse. Morse, Warren charged, had not cared passionately enough for the souls in his care. Warren testified to the congregation's frustrations; month after month, the First Church of Charlestown heard the same tired sermons.

Warren admitted that Morse's "benevolent and enterprising mind" might seek "to act upon a larger sphere than to be confined to the narrow limits of his own Parish." He also allowed that his pastor's "numerous publications" had benefited the nation, but Warren asked "whether it [publishing books] is consistent with the obligation he is under to the people in his charge ... . even in a pecuniary view does it admit of a question whether it is doing justice to the people of his Parish?" Warren baldly put it to Morse: "Did they [the parish] not contract for, and are they not entitled to the whole of your services?"

It was ironic that Morse, who in 1814 was fighting the liberals in the name of Calvinism, was taken to task by his deacon for not teaching Calvinist doctrine in his own parish. Warren suggested that if Morse put aside the publications and public controversies:

Then would not his preaching be less general, less speculative, more Powerful and Pungent, distinguishing more clearly between the characters of real Christians and nominal professors. Would not he feel the importance of dwelling more on the doctrine of new birth, on regeneration, and on the absolute necessity of a change-Is it not one of the most important parts of a minister's duty to convince the people that they are sick, for who will apply to, or want the help of a Physician, so long as he thinks himself perfectly whole-Is their not great need of dwelling much on these, to guard people against self love and self-flattery. ${ }^{47}$

This was hardly the ranting of a Unitarian.

By 1814, the time of Warren's letter, Morse's church was already beginning to unravel. The Baptists of Charlestown had established a church in 1801; the loss to the First Church, approximately eleven souls, was small. In 1810, many of the younger generation in Morse's church left and established the First Universalist Church. It is hard to calculate the loss to the First Church, but it must have been substantial; a number of the town's important families (the Frothinghams, Rands, and Harrises) were involved in the enterprise. The most serious fracture in the membership of the First Church, however, came in late 1815 and 1816, when 
many of Morse's wealthy and influential parishioners established the Second Church of Charlestown. ${ }^{48}$

No doubt the tension of the Unitarian-orthodox conflict was one cause of this split. In the course of this conflict the practice of pulpit exchanges had suffered. By 1815, the Charlestown parish could no longer hear the voices of other ministers from the Boston area. Confronted with only orthodox preaching, many opted for the new church. The end of the war with England also may have helped create an atmosphere in which Charlestonians felt more comfortable pursuing their differences. Finally, the split of 1815 and 1816, although reflecting the conflict between Unitarians and orthodox, was also spawned by the years of conflict between Morse, his congregation, and the town over his devotion to publishing, reform organizations, and other activities outside the church. ${ }^{49}$

The second element of Morse's failure as a minister and citizen of Charlestown involved his long and complicated dispute with Hannah Adams. The controversy itself was petty, but what it revealed about Morse was not. In the course of the dispute he acted badly, saw conspiracies where there were none, and generally lowered his reputation among his enemies and friends. In the course of the bitter feud the comments of his enemies revealed much about how people in the Boston area thought of Morse.

The controversy began when Hannah Adams spoke with Morse after the Thursday lecture in September 1804. She was certainly a sympathetic character. Unmarried, aging, and with failing eyesight, Hannah Adams made a meager living from her publications. In 1799 she had published a Summary History of New England and was in the midst of abridging it so that it might sell as a school book. She apparently attempted to ask Morse if he planned to abridge his A Compendious History of New England and, if not, was he willing to have her publish her abridgment. Morse gave her assurances that she could proceed without anxiety. Soon, however, Adams received a disturbing letter from Morse. He had discussed the matter with his coauthor ("my partner") Reverend Elijah Parish and Parish was unhappy. He thought that if Adams published an abridgment "it will look too much like rivalship" and that it would "hardly be proper." As for Morse, he believed that if the two works came into the bookstores at the same time the public would think one of them was unnecessary. After further discussions with Parish, however, Adams felt more confident and produced her school text in 1805 . When she attempted to place it for sale in bookstores, she was told that Morse and Parish were about to publish a similar abridgment of their work and that there was no room in the market for hers. At this point, Adams enlisted the aid of Stephen Higginson, Jr., a member of a wealthy Boston Federalist family. Higginson apparently persuaded Morse and Parish from competing directly with Adams's 
work in 1805. In 1808, however, Morse and Parish planned to produce a printing of their Compendious History. This revived the issue and gossip about Morse's sharp practices, and his callous treatment of Adams surfaced once again. ${ }^{50}$

What had really happened? Had Morse and Parish tricked Adams? Was it all a misunderstanding? We shall never know, but one thing is clear: Morse acted with a keen sense of the market and his own self-interest. This became clear when, as a result of the negotiations between Morse and Higginson, the dispute was submitted to a panel of referees. Morse was upset when in vague and confusing language they ruled against him. The referees acknowledged that Adams had no legal claim against Morse and Parish but that, on moral grounds, Adams, who depended solely on the income from her books, had been treated unfairly. Furthermore, the referees suggested that Morse and Parish owed Adams some financial settlement. Morse, for his part, fought the idea that he owed Adams any money. The controversy died away for several years after Adams gave up trying to obtain a settlement from Morse. In 1812, Morse revived the dispute when he wrote the referees asking them to clarify their decision. They stated that Morse and Parish "owed to Miss Adams a substantial and valuable recompense for their interference with her work." This, too, Morse refused to accept. He steadfastly refused to acknowledge that he owed Adams anything.

Nine years after the controversy began, Morse was still evading the clear meaning of the referees' decision and doggedly defending his character. He repeatedly approached Adams with offers of compromise, but he never was willing to offer her a cash payment for the harm she had suffered. He decided in 1814 to put the whole matter before the public in a massive volume that included the letters exchanged between Morse and Adams and a raft of related documents. ${ }^{51}$ This book backfired on Morse; some of his friends in the orthodox camp returned the book unopened and told him to pay up. Reverend David Osgood returned the book with a letter that suggested Morse had lost his reputation. He called Morse's response to the referees' judgment "unworthy of your character," and he claimed to "have heard mercantile men repeatedly say, that were one of them to have recourse to similar evasions, his reputation would be forfeited." Morse suffered not only from his friends but also from his enemies. Adams and her allies soon published a retort to Morse's work and they pulled few punches. Adams claimed that Morse made between fifteen hundred and two thousand dollars a year from his publications, "besides his ample salary as a clergyman," yet he was unwilling to let her have even the small part of the business to which she had devoted her life. Some of Adams's friends contributed to the volume and took as their theme Morse's 
double personality. They essentially played on the conflict between Morse's role as minister and his penchant for business. John Lowell, for example, called Morse "too well versed in all the arts and chicane of worldly men, for a minister of the gospel, which breathes peace, and requires a singleness and simplicity of heart and conversation." Stephen Higginson suggested that Morse's behavior in the Adams controversy had been the same as in the Harvard controversy, when Morse had strongly opposed the appointment of a liberal to the college faculty. In both cases "the conviction became general that he had concealed his real character" and that behind the facade of a gentle parson lay a mercenary man. ${ }^{52}$

The Adams affair heightened the tensions between the liberals and the orthodox. Morse saw the entire dispute as essentially over religious doctrine. All the attacks on his reputation, of whatever type, Morse considered "as aimed ultimately at the doctrines which I defend. I repel these personal attacks in defense of these doctrines." He turned the charge of duplicity aside, characterizing it as merely a disguised attack on his religious views. Certainly, he had support as he took this position; Timothy and Sereno Dwight confirmed his self-serving view of the controversy. Ward Safford wrote from New Haven that "happy indeed must be that man who is persecuted for righteousness sake-Your friends here are not so cold as some of those who live in more northern climates." This suggested that Morse may have complained about the lack of support from the orthodox in the Boston area. ${ }^{53}$

Morse was supported in his conspiratorial view of the Hannah Adams affair by the troubles Reverend John Codman experienced. Morse and Codman had stood together in the orthodox ranks since 1805, when Codman had written for Morse's Panoplist. Installed in the Dorchester church, Codman's orthodox views and his refusal to exchange with liberal ministers evoked a movement within his church to break the pastoral relation. A series of councils followed, and Morse was deeply involved in the process, but no resolution could be found. Morse and the Charlestown lay representative to the councils, Jeremiah Evarts, published a long review of the Codman affair in the Panoplist. They saw the conflict as theological; Codman had been driven from his church for preaching the true orthodox doctrines of the Bible to a people, addicted to sinfulness, who wished not to hear "the great truths."

By spring of 1815, the conflict between liberals and orthodox in the Boston area had soured beyond redemption. Routinely, pulpit exchanges were rejected; both liberals and the orthodox grew more exclusive. The liberal minister Joseph Lathrop wrote Morse that after discussing the matter with Morse's deacon, Lathrop thought it best, given the attitude of his membership, that "a suspension of exchanges for a time might be prudent." The level of invective from both sides became shrill and strident. 
At this point, March 1815, Morse learned from his son, Samuel Finley Breese, who was studying in England, that a book had appeared in London that contained a revealing account of Unitarianism in America. When he finally found a copy of Thomas Belsham's Memoir of Theopbilus Lindsey, he read what he had long been looking for-what he considered definite proof of a liberal conspiracy against orthodoxy. Professing to offer only facts and not interpretations, Morse published a pamphlet that reproduced the most incriminating parts of the Memoir. Particularly explosive was a letter from Bostonian William Wells to Belsham written in 1812; Wells wrote that religious liberalism was making steady progress in Boston, but that liberal ministers did not preach their views openly. The letter from Wells made Unitarianism look sneaky, if not conspiratorial. With the publication of the Unitarian pamphlet, Morse succeeded in beginning the last days of Congregational unity; it was for him the end of a long complicated process that had begun in 1789 when he came to Charlestown and quickly perceived the growing pluralism of religious belief in the area. For almost thirty years the fight against liberal sentiments in religion had never been far from the center of Jedidiah Morse's mind. 55

Morse called for separation between the liberal and orthodox brands of Congregationalism for several reasons. The end of the war with England no doubt removed an obstacle to opening the conflict fully. With the return of peace, maintaining national unity no longer was as important as it had been during the war. Morse, like many others among the orthodox, saw Unitarianism as causing immorality. Liberal ministers, Morse thought, countenanced sin by not preaching against it and by sugar-coating the hard truths of the Gospel. At one level, Morse was a true believer in the brand of Calvinism he so stoutly defended. At the same time, however, it is important to remember that the pamphlet on Unitarianism that called for separation came on the heels of the Hannah Adams dispute and Morse's massive summary of the Adams conflict in which he had also called for separation. In that dispute the main charges against him, duplicity and greed, struck perilously close to home. Morse never sought to directly answer these charges; instead he insisted that the conflict with Adams and her liberal champions was part of a Unitarian plot. All this suggests that a vital element in Morse's constant attacks on the Unitarians was a desire on his part to project onto them qualities that he feared were in fact his own. Accused of having a double personality (mild minister masking an aggressive entrepreneur) Morse, anxious that the charges were true, discharged that anxiety by portraying his enemies as concealing secret motives and plans behind their benign exteriors. At times this desire to paint his enemies with the brush they were using on him became childishly clear. In his volume on the Hannah Adams affair, Morse admitted that the conflict 
had publicized "aspects of his private life." He consented to answer any questions the public or his enemies might have, if they would answer all questions about their religious beliefs. In such infantile exchanges Morse revealed his desire to project duplicity and the possession of a hidden character onto his enemies. We cannot fully understand Morse's crusade against the liberals without understanding the degree to which it involved the projection onto his enemies of negative qualities Morse feared he possessed. ${ }^{56}$

To lay the groundwork for this understanding we have to explore Morse's financial life and reputation between 1800 and 1819 . There is substantial evidence that during this period Morse's reputation suffered. During the final chapter of the Hannah Adams fiasco Morse was generally portrayed as a greedy man too deeply involved in money matters. Higginson and Lowell, especially, took Morse's desperate attempt to clear himself in 1814 as an opportunity to make public what a number of Boston-area people already knew, that Morse seemed more interested in his own financial health than in the strict morality he preached from his pulpit.

Presenting a portrait of Morse's financial life and reputation is very difficult; important evidence is simply gone forever. Furthermore, we know little about Morse's intentions; he said little about his financial affairs and even less about why he became engaged in so many ventures. Whatever Morse's intentions were, he gradually lost the battle to keep his financial life and reputation intact. Establishing a link between Morse's financial fortunes, the Hannah Adams conflict, the Unitarian-orthodox split, and Morse's eventual dismissal from his pulpit requires an extensive look at Morse's financial life between 1800 and 1819.

Throughout this period, Morse continued to publish geographies and other works at a steady pace. The American Universal Geography, the source of the smaller works, appeared in revised and larger editions in 1802, 1805,1812 , and 1819 . He routinely produced new editions of the smaller works; for example, Geography Made Easy went through thirteen editions between 1798 and 1819. In addition to this output Morse published several editions of the New England history text that caused the problem with Adams, and a number of gazetteers and miscellaneous works. For example, in 1816, he apparently reprinted, at his expense and risk, a geographical dictionary by Richard Brooks. Although it is impossible to estimate the sales of these works accurately, it is reasonable to assume that Morse continued to take in sums from his publishing ventures that dwarfed his salary.

In the 1790s, the income from his books made him wealthy and, by 1803 , he felt settled and affluent. Quickly, however, his investments began to turn on him. In the late 1790s, he had purchased some Maine land from Samuel Goodwin. In 1804, Goodwin's son, William, had become Morse's enemy within his congregation. Although William made no men- 
tion of money matters, his sister, Eliza, did. In 1807, she apparently wrote Morse claiming that he had cheated her father out of four hundred dollars in the land deal. Morse wrote back professing his innocence and chastising Eliza for her lack of deference and gratitude. He claimed he had purchased the land as a favor to her father. The upshot of the matter was that Morse's speculations in Maine land led directly to the creation of bad feelings and inevitable gossip. The Goodwins became his enemy in the town and parish. ${ }^{57}$

Morse's ample income apparently offended his aging father back in Woodstock. In 1815 the old man made a significant alteration in his will. In the original document Jedidiah and Calvin were given symbolic bequests of ten dollars. In the codicil to this will, attached in 1815, the father cut these gifts in half because these two sons had possessed their inheritances since "Early Life and have had the profits and avails thereof to help them to a comfortable and opulent living in the world." Because the oldest son, Jonathan, was responsible for paying these bequests, the father's codicil amounted to a subtle sign to the sons who had "left" that the father preferred the son who "stayed" and cared for the aging patriarch. Morse's problems with the Goodwins and his family in Woodstock hardly constitute proof that Morse was a heartless money-grubber; they do illustrate that Morse was hearing from important sources challenges to his public reputation as dedicated minister and his internal sense of worth. His sense of self was disturbed; letters from the Goodwins and his father's letters and will helped create in Morse a fear that he was what they said he was: a minister too interested in wealth. ${ }^{58}$

While the words and actions of his father were important, Morse's most troubling relationship between 1800 and 1819 was with Aaron Putnam. This somewhat shadowy figure caused Morse nearly endless money troubles. These troubles became generally known and were the basis of many of the charges made against Morse during the Hannah Adams affair. Putnam came to Charlestown in 1789 and quickly amassed a substantial amount of property. Among other holdings, he owned a distillery shop and a large "mansion house" on the corner of Pleasant Street and the Salem Turnpike. Putnam joined Morse's church in 1792 and became a prominent member of the congregation, chairing the committee that determined Morse's new salary in 1803. Morse lent Putnam twelve thousand dollars in 1798 and took as security property Putnam owned near Henly's Point in Charlestown. In 1799, Morse lobbied his friend Oliver Wolcott, the secretary of treasury, to appoint Putnam a federal agent in the negotiations with the town that eventually led to the construction of the Federal Navy Yard in Charlestown. ${ }^{59}$

Morse's problems with Putnam did not begin until 1805. Putnam was 
clearly overextended and near bankruptcy. In addition to the mortgage, Morse had cosigned a bank-loan agreement for Putnam. Panicky, Morse helped his friend secure a loan from a Mr. Fairweather, which Putnam used to pay off the bank. At about the same time, Putnam discharged his 1798 mortgage to Morse, and on October 28, 1806, entered into another mortgage with Morse for ten thousand dollars, putting up his mansion house as security. On the same day, Morse sold part of this mortgage to Samuel Parkman and lent Putnam an additional six thousand dollars secured by that property.

This series of transactions caused Morse much grief. It was widely believed that in 1806 Morse had helped Putnam obtain a wife who helped him out of his difficulties, if only temporarily. During the Hannah Adams affair, Stephen Higginson accused Morse of making "mercenary matchs" for his own benefit. Essentially, supporters of Adams believed that Morse had used his influence to persuade Sarah Fairweather to marry Putnam and convinced her father to aid Putnam financially. The Vital Records of Charlestown indicate that on November 17, 1805, Putnam filed his intentions to marry Sarah. The available facts suggest that Morse, with his involvement in Putnam's financial affairs and the Fairweather family, gave his enemies a juicy charge to use when the time came. ${ }^{60}$

The complex dealings of 1805 and 1806 did not, however, save Putnam. In December 1806, Putnam mortgaged his distillery store to John Coates for ten thousand dollars. In October 1807, Putnam received an additional ten thousand dollars from Coates, again secured by the distillery. On May 6, 1808 , Putnam surrendered the property to Coates in satisfaction of the twenty thousand dollars owed but unpaid. In October 1807, Putnam borrowed an additional five thousand dollars from Coates, securing the loan with property already mortgaged to Morse and Parkman. At the same time, October 22, 1807, Putnam received twenty-nine hundred dollars from Morse, giving as security a lot and barn, and three thousand dollars from Samuel Fay, again mortgaging the mansion house already used to secure the earlier loans from Morse and Parkman. ${ }^{61}$

Early in 1808, Aaron Putnam's financial life collapsed. On February 12, Samuel Parkman took possession of the mansion house, but let Putnam remain in the house as a renter. In April and June, six different creditors obtained judgements against Putnam, totaling more than fifteen thousand dollars. In September, Putnam sent Morse a short note, the only communication between the two that survives. Putnam's sons had made their father some sort of deal contingent on Aaron leaving Charlestown. Putnam promised Morse that "if my life and health is spared and I should succeed you will be benefitted .. . I must bid you a hasty adieu." ${ }^{12}$

This note and a very cloudy title to Putnam's property were all Morse 
had for his trouble and expense. Putnam's collapse led to a spate of lawsuits in which Morse had a deep interest. In typical fashion Morse saw the litigation as more than it was; he wrote his son, "There is a strange mystery surrounding the business which I am not able to unravel." Indeed, the issue remained clouded; Morse had cosigned bank loans to Putnam and was probably being held accountable. By October 1813, Morse was still struggling to survive the disaster left by Putnam. On October 4 , he mortgaged his interest in the mansion house to William Bartlett for six thousand dollars and on the same day paid Samuel Parkman four thousand dollars for his interest in the property. One year earlier he had paid Samuel Fay the incredible amount of twenty-three thousand dollars for his interest in the property. On July 2, 1818, Morse sold the mansion house property, still encumbered with the Bartlett mortgage, for ten thousand dollars, thus ending almost twenty years of his involvement with Aaron Putnam's property. ${ }^{63}$

The long and painful involvement with Putnam was significant for several reasons. During the process, which was of ten public, Morse revealed the dimensions of his wealth and his speculative ventures. John Lowell and Stephen Higginson no doubt had all the information they needed to paint him as a mercenary man in the drawn-out conflict with Hannah Adams. In at least one way, the Aaron Putnam debacle connected with his other activities. Morse, forced to borrow money to obtain a clear title to Putnam's property, turned to William Bartlett of Newburyport for a six-thousand-dollar loan. Bartlett, a parishioner of Gardiner Spring, was the leader of the Hopkinsian faction during the negotiations that led to Andover's formation. Bartlett was the source of much of the endowment that financed Andover's beginnings. Finally, Morse's complex dealings with Putnam suggest a conflict of interest. Putnam was a member of his congregation and, at one point, very important in determining Morse's salary and conditions of employment. This, at the very least, did not help Morse's reputation and may have contributed to his image as duplicitous. ${ }^{64}$

Putnam's failure had serious financial consequences for the Morse family. During the years between 1812 and 1815, Morse confronted very heavy expenses for the education of his children. Samuel F. B. Morse, during this period, was in Europe, at his father's expense, studying painting. The correspondence between the son and his parents was often devoted to money. Mentioning the Putnam estate again and again, the parents urged their son to be as economical as possible. In November 1813, Samuel learned that his father was nearly seven thousand dollars in debt and "obliged to borrow money to support his family."

The facts suggest that Jedidiah Morse was in more financial trouble than he admitted to his son. Just as the Hannah Adams conflict was reach- 
ing its final episode, and Morse was being vilified as mercenary and overly involved in money matters, his financial life hit bottom. In December 1813 , he learned that his land in Vermont, which he had purchased in the 1790 s, was worthless. More importantly, Morse was confronted with a number of lawsuits that arose out of his speculations with printers and booksellers. In the summer and fall of 1814 Morse was defending himself against a number of actions against him. The booksellers, Whitney and Watson of New York, had failed and Morse was being called to pay a debt to them of "several thousand dollars." In November 1814, Morse wrote his son, Samuel, that Farrand and Mallory of Philadelphia had failed and that he was liable for four thousand dollars or more of their debts. This, he added, "may make me bankrupt." Perhaps his most bitter problems were with Samuel Whiting of New York. Whiting and Morse apparently had fought for several years over some turnpike stock that proved worthless. Whiting, for his part, sought seventeen hundred dollars due him from Morse, and Morse sought to prove he had been tricked in the stock purchase. ${ }^{66}$

Morse's money troubles touched his life in a number of ways. For example, it led to conflict and harsh words with his partner, Reverend Elijah Parish. In a bitter letter, Parish was astonished that Morse sought "to intimidate and frighten me to make a sacrifice from an idea of your insolvency." Morse had claimed a five-thousand-dollar loss and Parish responded, "I also have lost 5000 but I pay my debts without whining." Morse had also been involved with the historian Benjamin Trumbull, financing at his own risk one of Trumbull's publications. In July 1814, Sereno Dwight informed Morse that Trumbull was complaining publicly that Morse "had cleared 500 dollars out of his [Trumbull's] writings and that you have not paid him one cent." Dwight warned that this charge might make its way to Morse's liberal enemies. The liberals are persecuting me, Morse complained to Trumbull, and "my adversaries would doubtless be glad to make to wound me out of our unfortunate negotiation if they could. . . I trust, however, you are not disposed to yield them any aid in their persecution. . . I I know I have never intentionally done you wrong in any way." 7

Although all these financial matters may appear petty, to Morse they were not. In essence, in 1814 and 1815 the two layers of his life came perilously close together. The barrage of lawsuits and financial embarrassments pushed Morse's speculative and entrepreneurial life too close to his life as a minister and servant to God, community, and congregation. The letter from Deacon Warren, accusing him of being too interested in the world and too little interested in his flock, arrived in April 1814 and served as a backdrop to the growing crisis of 1814 and 1815 . His "last word" on the Adams affair, his Appeal to the Public, came off the press in 
the early summer and received a very negative response from friends and foes alike. It was in this context that he joyously sought, in the spring of 1815, the book his son had recommended in a letter from England; in it he found the material that allowed him to project onto the liberals in the Boston area exactly those qualities that he felt, and feared, he possessed himself. As he had persistently done since 1798 and 1799, in the Illuminati affair, Morse projected onto the world, and especially onto those who bedeviled him, attributes of dishonesty and duplicitousness.

The key to Morse's actions in 1815 was the demand for separation and the defense of New England tradition against innovation. By offering to the public excerpts from Belsham's Memoir, Morse claimed he was explaining to a worried public how radical and essential changes had taken place in some parts of New England. The similarity in tone between Morse's Illuminati sermons and his pamphlet on Unitarianism in 1815 was striking. The advice was the same: there is a secret plot against traditioncling to the verities of the New England past and meddle not with those who propose change. The attacks on the Illuminati and on the Unitarians were animated by the desire to create distance from evil plotters. There was in both cases no call to arms, no call for debate and decision; Morse wished, largely for internal reasons, to act out his own separation from evil, from unheroic compromise, and from his sense that he was touched by both.

Significantly, once Morse exposed the Unitarians, he lapsed into silence on the issue. The debate over theology that followed went on without Morse. Never really interested in theological dispute, Morse's goal had been almost entirely negative. His positive defense of orthodox positions was minimal and never carried the emotional charge that came with his attack on his enemies. Furthermore, he was quickly confronted with a crisis in his congregation. Late in 1815 , he learned that a substantial number of his flock were going to leave and establish a new church.

The relationship between the Hannah Adams affair, the Unitarian crisis, Morse's deranged financial affairs, and this last and largest defection from his church, one can never know for sure. Only one of the defectors, Dr. Josiah Bartlett, revealed his feelings on the matter. He wrote Morse that a number of factors had induced him to leave; he was, for one thing, upset by the lack of pulpit exchanges. Bartlett clearly liked to hear preachers with different views and he objected to Morse's desire to give over his pulpit exclusively to the orthodox. Bartlett also claimed that he joined the new church because of Morse's "engagement in and encouragements of controversies which I supposed injurious to yourself and to the public." Bartlett, no doubt, thought back twenty years to when he, a young Masonic doctor, had opposed Morse and Robison during the Illuminati crisis. Morse's contentious career was beginning to cost him even his most loyal and long-standing parishioners. ${ }^{68}$ 
Stung by the large defection from the church in late 1815, Morse demanded a new vigor in church discipline and obedience from those who remained. He called for those sinners in the church to be pointed out and corrected. He suggested a day of fasting and prayer and the formation of a committee to investigate the morality and beliefs "of all the individuals whose names stand on the records of the church." By March 1817 Morse's spirits had lifted considerably; he wrote to Joseph Lyman that his church was in the midst of a revival. Typically, he portrayed the creation of the Second Church as "an artful and deep-laid plan to corrupt and destroy [my church]." Morse, however, was oddly joyous; he claimed that harmony prevailed in his church and that "none was more promising in the State."

Two years later, in February 1819, this joy dissolved like morning fog when he received a letter, signed by twenty-five of his congregation, calling for a council to end his ministry in Charlestown. After countless conflicts with his church, Morse, at first, took this crisis in stride. In a letter sent to all his children, he told them that the affairs of the church were in "an interesting state ... another attempt at removal of the Pastor is now making." He laconically summarized the congregation's reasons for wanting his removal: "The publication of the Geography is the pretence." Indeed, Morse, this time aided by his sons, was busy in the winter of 1818-19 preparing for the press the seventh edition of The American Universal Geography. The twentieth edition of Geography Made Easy also appeared in 1819. ${ }^{70}$

The leader of the opposition was John Soley, a Charlestown lawyer. Morse and Soley had an interesting history. Soley had served in the registry of deeds office in Middlesex County during the time Morse was having his problems with Putnam. Much more important, however, Morse controlled the property of Soley's wife. It all began in 1804, when Morse and Artemas Ward signed an "Indenture tripartite" with Soley and Rebecca Tyng Henly. Rebecca, in 1804, stood to inherit the vast holdings of her father, Samuel Henly, who had recently died. Rebecca would take full possession of the property after the death of her mother, Catherine. She also wished to marry John Soley. By the terms of the indenture signed in 1804, the marriage could take place only after she signed over control of her inheritance to Morse and Ward, who held it in trust with full rights to manage it for Rebecca's benefit. Much of the document implied a distrust of John Soley and his intentions. For example, if Soley were to die before Rebecca, full control of the property would pass immediately to her. Only if Rebecca died childless would John Soley ever come to inherit the property of his wife. Fifteen years after he signed this document, Jedidiah Morse faced John Soley as the leader of the group who wished to oust him from his pulpit. ${ }^{71}$

Morse, in the early stages of the crisis, saw the actions of his congregation as conspiratorial. In typical style, he concluded that "the interior and 
connections of things could not be seen." Morse could not accept that many in his church were upset that their minister was publishing books again. Apparently, the dispute was submitted to "the Professors" at Andover and they had suggested that Morse accept dismissal. Unruffled by this, Morse planned to accept a colleague minister and stay on in Charlestown "for a few years." This would allow him to settle his financial affairs and leave his pulpit gracefully, not in defeat. The opposition, however, persisted, and by late April the Morses were a beleaguered family. Elizabeth wrote her son that the church simply wanted her husband out. She listed the opposition as including Deacon Warren, John Soley, Elijah Mead, and "Lot Poole who has gotten to be a Great Big Man because he can be Impudent as you please to the pastor." She also reported that these men were busy "looking up all the Dirt they can collect" about Morse. She portrayed herself and her husband as in the hands of "Wolves and bears."

Apparently, Morse gave up, for the moment, the idea of taking on a colleague minister and in May 1819 proposed that his connection be dissolved when the church agreed to a successor. The church agreed and put a one-year time limit on the search. During this period Morse gave, in some of his letters, a rare glimpse into the workings of his church. For one thing, he relied on the splits within the church to delay his final departure; he seemed sure they would have a hard time deciding on a replacement. $\mathrm{He}$ also suggested that gender was an issue. The opposition to him came only from males, and he insisted that "the Sisters are strongly opposed to a change." He had, by May, seen "the interior" of the opposition, or so he thought. His opposition, he concluded, "is obviously Unitarians." 73

When it looked like the church would quickly settle on one Mr. Cornelius to replace Morse, his son, Samuel, entered the fray. He wrote Cornelius that his father would prefer colleagueship and assured him that Morse's connection "would be as nearly nominal as possible." Samuel listed a number of reasons in support of this plan. Speaking for his father he stated that the colleagueship scheme "would give less occasion for the enemy to triumph. He feels that the public Impression will now be that he is driven away." $\mathrm{Mr}$. Cornelius soon withdrew from consideration or was rejected by the church-the record is silent on this issue. ${ }^{74}$

In late July, a climax of sorts arrived in the conflict between pastor and church. The church had again submitted the issue to the professors at Andover. The church may have inquired about the lack of candidates or about Morse's behavior toward those who applied. Morse reported to his sons the events that took place when the letter from Andover arrived. The letter, written by Morse's old friend and orthodox ally the Reverend Leonard Woods, wounded Morse deeply. The letter charged, in Morse's words, that he prevented Woods "from sending a preacher and that young men are 
unwilling to come and preach as candidates because it is disagreeable to me." Morse claimed the letter was full of sympathy for the church and the inhibited candidates, but "there is no sympathy for me expressed in this letter, it strongly implied censure. This conduct to me is unaccountable and wounding beyond what I can express." The Woods letter, Morse admitted, "awakened an almost furious state of mind in the opposition against me."75

By September the opposition had prevailed. In September, Morse wrote his son, "The die is cast-I go." Morse, however, remained stubborn to the end and, it seems, plotted to overthrow the agreement he made with the church. Under its terms, Morse would preach until the next spring and then leave whether the church found a replacement or not. Morse planned an October counterattack against his enemies, but his son, Samuel, talked him out of it. Samuel thought it would look "underhanded," that it would give his father's enemies a chance to call him "a plotting designing man." His son went on to beg his father to leave quietly; he suggested that continual combat with the likes of John Soley and Lot Poole "can get you nothing but disgrace." Finally he urged his father not to raise objections to Mr. Fay, who eventually accepted the job, "on Hopkinsian ground. . . . If you begin a controversy on these points it seems to me your troubles will cease only with your life." 76

The winter passed with little controversy between church and pastor. They haggled over money and other details. At one point a hot dispute broke out over the cost of window shades Morse had installed in the parsonage, but the squabble did nothing to disturb the plain reality that Jedidiah Morse had been driven from his pulpit. ${ }^{77}$

As things worked out, Morse did not give his farewell sermon until August 29, 1820. His replacement, the Reverend Warren Fay, however, was installed in the pulpit on February 20, 1820. Leonard Woods gave the installation sermon. Morse violently objected to Woods's references to him in the sermon and demanded that the remarks be stricken from the printed version; they were. Thirty years of contention and conflict ended with a quibble. The man who had devoted much of his life to defending the New England past was stripped of the pulpit where Shepard, Harvard, and Morton had preached. Bitter, he retreated to New Haven to live out his last six years. ${ }^{78}$ 


\section{6. \\ Family}

Jedidiah Morse was an author, speculator, reformer, cleric, and public figure. He was also a father and husband, a principal actor in creating a family. His family, beginning in 1789 , slowly took shape over nearly three decades. It produced three sons, one of whom became famous. But the Morse family, in the largest sense, was more complicated than an evolving parent-child story. The Deacon Morse in Woodstock, brothers Jonathan and Calvin, members of his wife's family, and a female servant, Anne Shepard, all played supporting roles. At center stage, with Jedidiah, was his wife Elizabeth, a crucial player in the family drama. Focusing on the famous son, Samuel F. B. Morse, several themes become clear. First, Jedidiah nurtured his children in a different world from the one in which he was raised. Nineteenth-century America imposed new tactics on the Morses, but they managed to pass on to their children much that they had inherited from their parents and from their own battle with a changing world. In the end, Samuel became a unique person who adjusted to his time just as his father had adjusted to his. Although unique, Finley, as he was called, reflected some of the same psychological conflicts and anxieties that had marked his father's life.

As Jedidiah Morse constructed his own family in Charlestown, as he took on the role of father, he remained, in important ways, a son. Deacon Morse assumed that his sons would defer to him as long as he lived. For the eldest son, Jonathan, deference was not hard to command; the father possessed the land the son coveted. With Jedidiah and Calvin, maintaining patriarchal control was more difficult; the deacon's codicil to his will that reduced the bequests to his "other" sons was eloquent testimony that the father felt proper deference was not being paid. Jedidiah could still feel the weakened paternal grip on him. His father lived for a long time; Jedidiah was fifty-eight and Jonathan sixty-nine when the deacon died in 1819. Until he died, the sons were not fully independent men.

Jedidiah Morse also remained a son, and dependent, because he could never fully embrace Charlestown, his home for thirty years. Charlestown was always inferior to his idealized image of home in the Connecticut countryside. In his geographies he often condemned the New England seacoast towns and celebrated the virtues of rural yeomen, men still on the land, men like his father and eldest brother. The constant promotion of the New England countryside and its citizens revealed Morse's wish to 
regain the secure, but dependent, status of a son in Woodstock. It also revealed his covert dislike of Charlestown, where he felt alienated and uprooted; it was the stage on which he had to play the role of an independent and autonomous man. As Morse noted in his geographies, New England was rapidly becoming "a nursery of men," sending thousands to all parts of the expanding nation. Certainly Morse saw himself as a product of this nursery, bound to stay loyal, like a good son, to the superiority of the New England Way. Given this version of lingering homesickness, he could never fully become an independent adult; some part of him was always making its way back to Woodstock and his childhood. ${ }^{1}$

Ironically, his brother Jonathan harbored no such dreams; locked in an embrace with his father and his father's land, Jonathan wished to get out. Apparently land-poor, he fell into debt. As he wrote Jedidiah in 1805, "I have got almost discouraged and talk of selling the farm if I had an opportunity and if Father was willing." He thought that it would be "for my interest and I believe my Comfort if I could get me a farm up in the Country that suites me."

Jedidiah remained connected to his childhood environment by more material factors. One of these factors was food. The letters between Woodstock and Charlestown contained news of political, religious, and personal affairs, but the most common subject was food. A brisk trade existed between the Morses of Charlestown and Woodstock. In general, Woodstock sent food and Charlestown paid for it with manufactured goods, textiles, or food unavailable or expensive in the countryside. Letters from the deacon would often deal with great issues and then abruptly turn to hats or a lost firkin of butter. In a letter from Morse to his father, the son began with weighty church and political matters but concluded: "You will have been informed by my last letter, that we depend on you for your pork. When you have opportunity to send it, we wish if you can to send us five dozen eggs in salt and a pot of good butter and some of your good sausages. We have ... in reserve for you, when we have opportunity to send them among other things 14 pounds of brown sugar and a little Lyson teafor which please send a bag." The deacon purchased his hats in Charlestown using his son and daughter-in-law as agents and paid for them with butter, pork, and other products of his farm. This family trade relationship was ambiguous. It revealed Morse's psychological dependence on his father and the staples from the family farm. Morse's independence was symbolized by the cash he used to obtain the goods he eventually traded for food. ${ }^{3}$

Indeed, the cash Morse possessed helped create another significant bond to Woodstock and his family. Apparently the deacon, Jonathan, and perhaps Calvin, borrowed money from one "Mr. Goddard." Early in the 1790s Jedidiah purchased all the "notes held against the family." He wrote his 
father: "Tell Jonathan not to be too anxious-all will issue well-the country is flourishing and all industrious economical men will not fail to get a comfortable living. So long as Providence furnishes me with the means I shall always stand ready to lend him a helping hand." From 1792, when Morse was assembling large amounts of cash from his publishing ventures, until 1820, when the deacon died, there existed a debt relation between the Charlestown Morses and the Morses of Woodstock. Only after selling the farm in 1820 did Jonathan clear the debts he owed his brother. The family homestead, their father's land, had to be sold to break finally the longstanding bond of debt that kept the Morses linked as a family. ${ }^{4}$

In addition to food and debt, business kept Jedidiah linked to Woodstock. He recruited members of the family to sell his books and subscriptions to the Palladium and Panoplist. His father acted as a marketing consultant, advising his son on rural attitudes about books, magazines, and newspapers. As early as 1791 , the deacon was selling the first edition of the large geography and smaller versions, but the price was high: "Several has seen them [the geographies] and like them better than they do the price." $\mathrm{He}$ also promised to promote the advance sale of the new edition of the two volume Universal geography that was in the works. Jedidiah also had a business relation with his Aunt and Uncle Moor, who sold his books, kept the cash, and paid Morse in food and yarn. As time passed they, too, fell into debt to Morse. ${ }^{5}$

Standing anxiously on the ground between son and independent adult, Morse began his own family in 1789. For three decades he felt the undeniable grip of paternal authority and the emotional ties to Woodstock. Time after time, he paid homage to his father and expressed his gratitude for the many advantages his father had provided. Yet at the same time, he sought to escape the traditional paternal controls and to make a life in an environment his father understood dimly, if at all.

It was into this context that the babies came. Three of the first four children born to Jedidiah and Elizabeth Morse lived long lives. Samuel Finley Breese Morse was born on April 27, 1791; Sidney Edwards on February 7, 1794; and Richard Carey on June 18, 1795. The second child born to the Morses, Jedidiah Edwards, arrived in September or October 1792 and died on July 31, 1793. After Richard's birth in 1795, the next six children died in infancy. Thomas Russell (1797), Elizabeth Ann (1798), James Russell (1801), Elizabeth Ann (same name again) (1803), Mary Russell (1807), and Sarah Rebecca (1808), all died within a year of their births. Elizabeth Morse bore her first child at twenty-five (Jedidiah was thirty) and her last at forty-two (her husband was forty-seven). ${ }^{6}$

The naming of the Morse offspring provides an interesting, but only suggestive, insight into the attitudes of Jedidiah and Elizabeth Morse. 
Samuel F. B. Morse was named after Elizabeth's father and grandfather. Sidney Edwards was named after his maternal uncle. Thomas, James, and Mary Russell honored the Russell family of Charlestown, who consistently supported Morse in his battles with his congregation. Richard Carey also took his name from a notable Charlestown citizen. The Morses twice attempted to name a child after Elizabeth, but both infants died. There was one attempt to carry on the name Jedidiah, linking it with Edwards, in honor of the maternal uncle and Jonathan Edwards. Jedidiah's brothers followed much the same pattern in naming their children. They often selected names with no obvious Morse family connection. Jonathan, however, did name his fif th child (third son) Jedidiah. Calvin never employed Jedidiah as a name for any of his four sons, but oddly named his last daughter Sallie Breese, honoring his sister-in-law's family name. It seems that in naming children, the Morse sons were more responsive to the idea of honoring ancestors from the maternal side, and to the idea of honoring notables in the new environments into which the children arrived. ${ }^{7}$

More interesting, and certainly more affecting, than the naming of the Morse children was the horrible infant mortality rate. Jedidiah and Elizabeth, living in Charlestown, suffered the sorrow of an infant's death much more often than the rural Morses. The information is incomplete (especially for Jonathan and Calvin), but of the twenty children born to Jonathan and Calvin, apparently, only one died young. Jonathan's ninth child died at age six. This must have been perplexing and tragic for the Charlestown Morses. They responded to the death of their babies with expressions of Christian stoicism. When Sidney Edwards was born, Morse wrote the deacon that he hoped the infant would live to maturity, but added, "We have given him back to Him who gave him to us to do with him as shall seem good in His sight." After the birth of Elizabeth Ann in 1803, Morse again wrote his father that "we have had sufficient warning not to place our affections inordinately on enjoyments [infants] of so precarious a nature. I hope it is our endeavor to possess this and every other temporal blessing as though we possessed it not." After the burial of his infant daughter in 1799 he wrote Walter King, "I pray that it may be good for us that we have been thus afflicted." The Morses hardened themselves against the reality of infant death and accepted it as part of God's will. Yet given the success of their rural kin in bringing infants to adulthood, the Morses of Charlestown may well have thought themselves unduly afflicted. So many infant deaths also may have made the surviving children all the more precious and important to the parents. ${ }^{8}$

The filling up of the Morse's household extended beyond the production of sons. Probably before the birth of Finley, Jedidiah and Elizabeth took into their family Anne Shepard, who was always called Nancy. At 
first a servant-nurse, she became a fixture in the Morse household. In the Deacon Morse's letters to his son, he of ten listed Nancy as a member of the family. Her signature often appeared on Morse's official documents as one of the required witnesses. In his will, Jedidiah made a symbolic bequest to her, honoring her for her years of service. Anne Shepard left few historical traces, yet she was an ever-present element in the Morse household. The Morses, at least once, took in another child. In 1792, Jedidiah and Elizabeth added to their household Walter Moor (sometimes Moore), the son of Hannah and Walter Moor, Jedidiah's aunt and uncle from Union, Connecticut. Walter was admitted to the First Church of Charlestown in November 1795 but not long after that became ill. All the evidence suggests that Walter Moor either died or left Charlestown before 1799-1800. ${ }^{9}$

So the cast of characters was complex and changing. The Morse family of Charlestown included three sons, a lifelong servant, one temporary visitor, and, sadly, the ghosts of too many infants. The lead roles, however, were played by Jedidiah and Elizabeth. Over time they developed a relationship based on silent assumptions and tacitly agreed on roles and rules. Their marriage was different from that of Jedidiah's mother and father in several ways. Sarah Child Morse, Jedidiah's mother, made only the faintest mark on the historical record; she was a wife and mother in the most patriarchal of homes. For most of her life she shared her home with her mother-in-law, to whom she owed deference. Her husband was an everpresent fixture in the home; the deacon not only farmed his own land and pursued his farrier business there, he conducted public business as a justice of the peace at home as well. In Jedidiah's mind home meant father; letters home were addressed to the deacon with only marginal mentions of mother, and letters from home were clearly from his father. The epistolary "corrections" and advice that nagged at Jedidiah for nearly four decades clearly came from his father.

As a wife and mother, Elizabeth Morse was decidedly unlike Sarah Child Morse. The Morse household in Charlestown was not as patriarchal as the Woodstock homestead. Jedidiah Morse was not a farmer, not a village worthy who ruled his domain from the front parlor. Jedidiah was away from home much of the time pursuing his business interests and reform activities. He was also, unlike his father, an employee. He worked for a congregation, a fact not mitigated by the special status accorded clergymen. As these realities subtly reduced Jedidiah's patriarchal dominance, Elizabeth just as subtly moved to expand her role. Elizabeth was a central figure in raising the children. In Woodstock, the influence of females often ended at age five or so and the men took over. Elizabeth Morse remained a central influence on her sons as they grew to adulthood and be- 
yond. In fact, her role expanded as her sons grew. The evidence was in the letters to and from "the boys" who were away at school. The early letters (1797-1805) were jointly authored, but gradually Elizabeth began to dominate. The later letters (1805-26) were usually written by Elizabeth with a father's postscript that of ten amounted to little more than an admonition "to listen to your mother." Jedidiah Morse became less a moral force in his children's lives during those years in which he was embroiled in the fiercest controversies and entangled by his land speculations.

The relationship between Jedidiah and Elizabeth revealed a more independent and assertive wife, one who assumed that the achievements of the couple had been jointly won. Elizabeth was a player in the long conflict between her husband and the congregation; several letters note bitter conversations between Elizabeth and hostile deacons. Elizabeth was involved, as well, in her husband's business affairs; often she was the one to arrange collections or payments on notes and debts. She certainly saw her life with Jedidiah as an economic and emotional partnership. In a letter to Samuel F. B. Morse, she claimed:

Your Parents set out in Life about twenty five years ago. They had nothing for a support but their salary which was a House 20 cords of wood and 570 dollars a year. The reception and circulation of the Geographies was an experiment not yet made. With the blessing of heaven on these resources, we have maintained an expensive family, kept open doors for almost all who chose to come and partake of our Hospitality. We have given you and your Brothers a Liberal Education. . . . This is a pretty correct statement and I make it to shew you what can be done by Industry and with the blessing of Heaven. ${ }^{10}$

Jedidiah and Elizabeth Morse raised their sons with the deadly serious dedication with which they did most things. Child rearing is, and was, a dialogue in which the parents speak and act and the children respond. The Morses sought, in the first place, to create in their sons, and particularly in the eldest, an overwhelming sense of gratitude, a feeling of indebtedness to the parents. They insistently reminded Finley of his financial and emotional debt to his parents, and they made "good behavior" the coin in which the debt was paid. Samuel F. B. Morse was inculcated with the same lifelong sense of obligation and nagging need to express gratitude that the deacon had instilled in Jedidiah Morse. The Morses defined good behavior in a complex way. Its central element was a cluster of values best labeled the Protestant work ethic. Finley was constantly advised and cajoled to be economical, virtuous, and hard-working. Virtue, in this case, had both positive and negative elements. Finley was to be a 
productive and valued member of society by finding moral work, and through this work become an independent person, respected by respectable people. In part, this meant learning "economy"; in essence, he was taught to seek money but not enjoy it. While seeking moral work and its material rewards, Finley was taught the dangers inherent in the love of play. Often the injunctions against play and leisure assumed the existence of a hostile and immoral world ready to trap the unsuspecting person into unthinking immorality. Although trained to seek an independent status through hard work and economy, Finley was just as often pushed to seek pious dependence on God and the opinion of others. In the end, his parents' side of the dialogue contained an irreducible tension between morally sound independence and a pious dependence. Finley was to seek both, all the while knowing that the love of his parents was dependent on his good behavior.

Jedidiah and Elizabeth were hardly unique parents. They had much in common with other parents of the time. In contrast with evangelical households, the Morses were middle-class moderates because they rejected corporal punishment and fear in dealing with their children. The emphasis, instead, was on love and the internalization of values, the psychological internalization of the parental voice as conscience. Freud suggests one way of looking at this type of child rearing, capitalism suggests another. Much of what passed between Jedidiah and Elizabeth and their children sounded suspiciously like bargaining - very complex bargaining. The parents of ten introduced God into the negotiations, as if they regularly consulted him about the children, which they probably did. The parents also employed the grandparents in bargaining with their children. For their part, the children, especially in their early years, had little leverage. However, youngsters like Finley Morse, soon learned to play the game. He learned that parental love, support, and a modicum of freedom from parental domination could be purchased with signs of good behavior and statements of gratitude and obedience, provided ritualistically at the appropriate moments. In a culture moving steadily toward a total embrace of capitalism, it is not surprising that parents like the Morses should, perhaps unconsciously, begin to use the language and rituals of capitalism in raising their children. Certainly Jedidiah Morse knew the language and rituals well enough. ${ }^{11}$

Samuel F. B. Morse spent much of his first twenty-five years away from home being taught by others. At four he was sent to a local school conducted by "Old Madam Rand"; she taught basic discipline. An invalid, she ruled a small room full of three to five year olds by employing a long rattan to hit evildoers beyond her reach and by pinning those she could grab to her dress. At seven, he entered Andover to prepare for Phillips 
Academy, which he entered in 1799. In 1805, he went off to New Haven and Yale, but he was there on a conditional basis. His father's friend, and the president of Yale, Timothy Dwight, decided when the young Morse had caught up sufficiently to "join his class." He eventually did and graduated in 1810; Samuel was an indifferent student. ${ }^{12}$

Because the son was away so much, letters became crucial in the childrearing process. It was in these letters that the parents' intentions for their son became apparent. The early letters, when Finley was eight or nine years old, were general in tone; they asked for good habits and behavior; they made it clear that the parents' affection for their son was at stake. The letters in November and December 1799 were typical. Samuel learned that his parents "are anxious that you behave well"; he should remember "how important it is to your own happiness and to the happiness of your parents that you form and maintain a good character." The injunctions to work hard and avoid excessive leisure began early: "Don't let play occupy too much of your time or attention. Remember time is precious and should be well improved." The parents also made it clear that they hoped God would "incline your heart to that which is good and that he make you the subject of his early grace." To insure that Finley sought this early grace, Jedidiah and Elizabeth insisted that he memorize "the Assembly's Catechism," which was, in their view, "an excellent summary of the Christian religion." Jedidiah and Elizabeth promised as a reward for "good behavior" to bring their son home to Charlestown during vacations. If, however, the reports from Andover were negative, Samuel would have to stay at school. ${ }^{13}$

All of Jedidiah Morse's sons attended Phillips Academy, thus adding an additional pressure for them because their father was an overseer of the school. He made regular visits to the academy, like the one he made in 1799, while Finley was in attendance. During that visit he addressed the students on the theme of gratitude. The students should, he urged, feel a sense of indebtedness to their parents and to the wealthy benefactors who had created Phillips. This was particularly true given "the present disorganized state of society." The message was clear: the environment in the United States was "seductive and demoralizing," and "youthful curiosity" could lure the young to "enchanted ground where you will be easily bewildered and lost." Morse specifically warned the students about "those books that have been pouring into our country . . . circulated with much art and industry among young people, which are replete with concealed, but deadly poison to your principles and morals." What Morse told the students, he and Elizabeth also inculcated into their sons. Samuel came to understand that, as his mother put it, "it is easier to earn a reputation than to keep it unspoted in the midst of so much pollution as we are surrounded 
with." ${ }^{14}$ All three boys quickly learned that the world was a tricky and impure place.

In addition to their father's vision of the world, Finley and his brothers also inherited their grandfather's. Clearly supporting Jedidiah and Elizabeth, Deacon Morse wrote all the boys "to be obedient, dutiful and obliging to your Parents ... in some good degree reward them for their Care and faithfulness in raising you up." He advised them "to use and improve" their minds for the "best of purposes which is to glorify God while we live that we may Enjoy him forever after Death." The deacon reminded them of the "sad experience in the family of which you are a part [the infant deaths]," suggesting that because they had been spared, God must have some special purpose in mind for them. After reminding them of the "Care, Cost and Expense in your Education," the patriarch stated that the parents "expect their reward in your future good behavior and usefulness in the World." "Wicked practices" and "an Ungodly life" lured too many young people to their ruin, he thought. He issued a ringing denunciation of "Recreations and amusements," believing that there was a "great danger" at schools "where a multitude comes together of Various Characters and Disposition of carrying Recreations to Excess." All the Morse sons learned that the world was replete with snares for the young, that in books, play, and "where a multitude comes together" lay dangers only vaguely understood. ${ }^{15}$

By age ten Samuel must have had a fairly clear view of the task confronting him. He was to seek a good character by being industrious and quest for salvation in a world soiled, polluted, and full of false guides and temptations. Soon it was obvious to his parents that he was failing. Jedidiah Morse apparently received regular reports from Andover concerning his oldest son. These reports told of a son "regardless of truth, idle, at the bottom of your class." The response in Charlestown was predictable. The idler at Andover would not come home during vacations until his behavior improved; Samuel knew that his failings had hurt his parents deeply. The letters up to 1801 had laid out a general program, but after that time the parents clearly felt they were dealing with a weak character. Most important, they demanded a letter a week that related everything. For the next fifteen years the parents regularly renewed this demand for detailed introspective letters, for progress reports on his character and religious feelings. ${ }^{16}$

In October 1805, Finley made his way to New Haven and Yale College. He was to spend some time making up his educational deficiencies, and his actual admittance to Yale was held in abeyance. He first letter home from New Haven laid the themes that dominated his relationship with his parents. He apologized for not writing sooner to announce his safe arrival. In what was by then a ritual, he wrote that he was "sorry for giving my good parents so much trouble and expense. You expend and 
have expended a great deal more money upon me than I deserve." He promised his parents what he knew they wanted to hear: "You have granted me a great many of my requests and I am sure I can certainly grant you one, that of being economical. . . . I begin to think money of some importance and of too great value to be thrown away." 17

But the promises proved hard to keep. Samuel's parents were alert to every sign of weakness in his character. A request for "Brandy, Wine and Sigars" and an idle remark about hunting produced a diatribe about sloth and excessive recreations. Elizabeth, using her son's own words against him, claimed, "I am truly sorry that you appear so unsteady as by your own account you are." She was also especially angry that money (a five-dollar bill), sent by mail, had not been acknowledged. She demanded to know literally everything he did-how "pocket money" was spent, how much laundry cost, and who Samuel heard preach-"let your lines in your letter be very close and fill a large sheet very full." Another letter from his mother in November 1805 employed his father as a role model. Elizabeth claimed that Jedidiah was capable of great labors because "he early imbibed habits of Industry and Application to his studies which have grown up with him." For Jedidiah and Elizabeth, a boy became an independent and useful man by a prodigious exercise of self-control. Industry and economy were the keys to adulthood. ${ }^{18}$

The lessons proved hard to learn. In 1807, Samuel and his parents were still debating the proper role for hunting, or "gunning." Samuel begged to be allowed to go gunning: "I have no amusement now in vacation ... I suppose you would tell me that my books ought to be my amusement. I cannot study all the time." Samuel did not become more adept at handling money, either. In 1808, in a letter reminiscent of his father's letters home from Yale, he wrote, "I find it impossible to live in College without spending money." Money was a central issue between the college boy and his parents. Samuel wrote: "When I have money in my hands I feel as tho I had stolen it and it is with the greatest pain that I part with it. I think every minute I shall receive a letter from home blaming me for not being more economical and thus I am kept in distress all the time." ${ }^{19}$ Money, its possession and use, had become a crucial symbol of Samuel's dependence on his parents. Therefore, money of one's own, the product of one's industry, could mean freedom from parental dominance.

At times Samuel must have felt that economy and self-control were all his parents cared about. There was, however, another theme. Both parents made Samuel's spiritual state a special concern. Early in his life Samuel was gently encouraged to be concerned about his soul. By the time he reached Yale, the issue took on a new dimension. Samuel was often reminded of the first question and response in the assembly's catechism: 
"Q. What is the Chief End of Man?-A. To Glorify God and enjoy him forever." "This," Elizabeth claimed, "is your chief aim." Both Elizabeth and Jedidiah watched Samuel closely for signs of piety and religiosity, but found none. In their attempt to make him turn to God, they reminded him often about the closeness of death. The death of a girl in Boston prompted this: "She ate her dinner perfectly well and was dead in five minutes. . . . You see ... the importance of being always prepared for death. We cannot be too soon or too well prepared for that all important moment as this is what we are sent into this world for. The main business of life is to prepare for death."20

In letter after letter the Morses reported "interesting" deaths to their sons and drew the inevitable lesson. A student suddenly dies of a mysterious fever and the parents write, "Suppose, my dear Son, it had been you instead of bim. What would have been your state. Ask yourself this important question." This tactic was, it seems, a family tradition. Deacon Morse also delighted in recounting significant deaths and in philosophizing on their meaning. Therefore, it was not surprising that Samuel became somewhat gloomy and fixated on death. One of the very rare pieces of schoolwork that he kept from his Yale years was an essay on death. It began by describing a frustrated student unable to compose an essay; he falls asleep and dreams of being down by the New Haven harbor. A storm begins, driving the young man into "the thickest part of the forest." The storm rages on, and just as death closes in, the student comes upon a Gothic castle. The castle has two turrets, one is upright, the other in near ruins. In the ruined turret, the student sees a light, and going to it, he finds a chapel and a "tall emaciated figure." The figure beckons the student to follow; they arrive at a vault beneath the castle. The student enters "the gloomy dungeon," and in the near total darkness he finds a corpse. Here the essay ends. Such essays were common, no doubt, among school boys in the early years of the nineteenth century; but given Samuel's intimate experience with death and his parents morbid use of it to instill religious inclinations in him, this essay suggests that Morse came close to being obsessed by the subject. ${ }^{21}$

In general, however, Finley's years at Yale were dominated by a struggle with his parents over his character. He learned that promises of good behavior were coin with which to purchase his parent's approval. News of Sarah Rebecca's death late in 1808 produced this promise from Finley: "I know it must afflict her [Elizabeth] to be deprived of so many of her children, but I hope her children who have been spared will afford her comfort, sufficient to overbalance the affliction, I will endeavor for my own part to behave in such a manner that you will have no cause for blame in my conduct this term." 22

Morse was beginning to respond to the years of preaching and plead- 
ing from his parents. He was internalizing the commandment that his behavior should satisfy his parents, allay their grief, and fulfill their expectations. More important, he began to accept his parents' criticism as true. Reflecting the same sentiments his father had expressed at Yale twenty-five years earlier, Finley noted that the world was divided between the moral and the immoral. He promised to befriend only "the most religious and moral," and he hoped "that it will have a good effect in changing that thoughtless disposition which has ever been a striking trait in my character." He also admitted that "as I grow older, I begin to think better of what you have always told me when I was small. I begin to know by experience that man is born to trouble, and that temptations to do evil are as countless as stars, but I hope I shall be enabled to shun them." 23

By the end of his college career, Samuel F. B. Morse had fully incorporated the contradictions of a moderate Calvinist child-rearing system. He believed that "man is born to trouble" and that the world was polluted by this fact. In response, one clung to a vaguely defined elect, the "religious and moral," while shunning the profligate and evil. At the same time one accepted a diluted version of innate depravity one also engaged in a rigorous program of moral education designed to overcome depravity, and to satisfy the authority who imposed the moral instruction. While energetically seeking self-control and a moral character, one sought grace from God and prepared for death. God's grace was elusive, however; it could not in the strict sense be earned. Yet death loomed large and one was urged to prepare for it by seeking God's redeeming hand: This type of child rearing created anxious and divided adults; dependence and independence mixed in an uneasy compound. There was no place of rest; at turns one felt empowered and powerless, independent and dependent, moral and immoral. Children raised in this way assumed that the environment was threatening and characterized by an ongoing war between the elect and damned. Such children sought "purity" or "purification"; imbued with an incoherent and disjointed identity, they sought to dissolve painful dissonances within themselves by creating a clear and overly simple image of social reality and their place in it. Often this purification process included a deep commitment to the idea of an inflexible moral system and the creation of conspiracy theories that reduced complex historical situations into artificially clear conflicts between conspiring agents of evil and beleaguered possessors of the truth. ${ }^{24}$

As Samuel's college days came to a close, he confronted the problem of finding a vocation. Jedidiah had drifted into the ministry with little apparent conflict between himself and the deacon. The clergy was not an option for Samuel, but he did have a decided preference for painting as a vocation. In July 1810, just before his graduation, Samuel wrote his par- 
ents, telling them of his desire to become an artist. He wished to go to England to study with "Mr. Alston" and asked his parents to pursue the matter with Alston. Samuel's request came at a bad time. The Morse finances were in disarray because of the Putnam fiasco, and the father asked his son "to earn as much as you can between now and Commencement. It will be a real aid to me just at this time." Samuel had begun doing "likenesses" in New Haven and was paying some of his own bills. His parents, however, assumed that they would decide their son's vocation. His father wrote: "On the subject of your future pursuits we will converse when I see you and when you get home. It will be best for you to form no plans. Your Mama and I have been thinking and planning for you. I shall disclose to you our plan when I see you. Till then suspend your mind."25 Till then suspend your mind. Never was the reality of parental control so clearly revealed.

His father came to New Haven for commencement and to reveal to his son his future. As it turned out, the parents decided to place Samuel as a clerk in Mr. Mallory's bookstore in Boston. On hearing his parent's plan, he quickly wrote his mother with his response. He claimed to be "pleased with it" and claimed that he was "determined beforehand to conform to his [father] and your will in everything and when I come home I shall endeavor to make amends for the trouble and anxiety which you have been at on my account by assisting Papa in his labors and pursuing with ardor my own business." Not only was Samuel to be a bookseller, but he was also going into the family business of making geographies-production and sales. While putting on a brave face and acting out the role of dutiful son, he was clearly disappointed. He wrote his mother, "I am so low in spirits that I could almost cry." 26

In the life of Samuel F. B. Morse, this escape from Mallory's book shop was crucial. He would go to Europe, learn to paint, and become an important figure in American art. Returning home from a later tour of Europe, he would conceive the telegraph, abandon art, and become rich and famous as an inventor. All this tends to obscure the fact that his father wanted him to pursue the book business. The decision to force his eldest son into Mallory's book shop said a great deal about Jedidiah Morse. The decision most probably reflected the father's financial situation in 1810 and 1811. In desperate financial condition, Jedidiah Morse always turned to the production of more geographies. By keeping his son at home he procured a well-educated assistant who could hasten the appearance of a new, and profitable, edition. Jedidiah also understood the costs of further education in Europe, and he was reluctant to pay them given his financial state. His money problems were further deranged by the costs of educating his other sons at Yale and beyond. 
Although the Reverend Morse may have made and then unmade a hard-headed financial decision regarding Finley's career, it had important psychological dimensions as well. Keeping Finley in Boston after graduation may have reflected the parent's desire to prevent their son's escape from parental influence and control. They were attempting to do what the deacon had done with his eldest son. Keeping Samuel at Mallory's was the equivalent of keeping Jonathan in Woodstock tied to the family enterprise. Like the deacon, Jedidiah remained deeply and oppressively concerned about his son's character and spiritual well-being. Having released him from the bookstore, Jedidiah established an extensive network of correspondents in England who regularly reported on Finley's habits and spiritual state. ${ }^{27}$ Confronted with their son's undeniable freedom created by his growing maturity and distance, the parents remained suspicious of him. Letter after letter called into question every action, expense, and attitude. Acting like letter-writing super egos, they never allowed him to fully extricate himself (as Jedidiah had never been able to do) from the constant pressure of parental distrust and insinuation. The letters had a dramatic impact on young Samuel; he pleaded with his parents to trust him to behave correctly. He continued:

It is a singular . . an unfortunate fact that I have not, that I recollect, since I have been in England, had a turn of low spirits except when I have received letters from home. It is true I find a great deal of affectionate solicitude in them, but with it I also find so much complaint and distrust, so much fear that I am doing wrong, so much doubt as to my morals and principles, and fear lest I should be led away by bad company and the like, that, after I have read them, I am miserable for a week. I feel as though I had been guilty of every crime, and I have passed many sleepless nights after receiving letters from you. ${ }^{28}$

This statement was reminiscent of Jedidiah's plea to the deacon in 1792 to "let me go on [making books] without anxiety." Finley's desire to paint and his father's "itch" to write geographies were oddly similar attempts to establish some independence from parental demands and expectation. Without diminishing the important differences between the father and the son, it is plain that they both failed to emancipate themselves. Jedidiah Morse lived his life as a divided and anxious man in part because he never fully freed himself from the internalized voice of his father. Finley was bedeviled by the same nagging whispers that many call the conscience but which emanate in the beginning from oppressive and distrustful parents.

In the decade after his return to America in 1815, Morse fell back into his parents' orbit. Attempts to establish himself as an artist failed; the 
long sought after goal of financial independence proved illusive. He married Lucretia Walker from New Hampshire and soon became a father, but he never came close to cutting the emotional and financial bonds that tied him to his parents.

In the child-rearing dialogue, the Morses created in Samuel F. B. Morse a divided man incapable of establishing his independence and a stable identity. In a way, Samuel was (with Elizabeth's considerable help) Jedidiah's greatest triumph. He never allowed his son to believe in his own innate goodness; the son came to distrust himself and the world as fundamentally as his father had. Indeed, because of this sense of distrust and generalized suspicion, Samuel was able, just as his father had, to make an important contribution to American conspiracy thinking. Finley's attacks on Catholicism were rooted in the same psychological ground that had spawned his father's assaults on the Illuminati and the Unitarians. ${ }^{29}$ Yet in the end Samuel saved his most profound distrust for himself. By 1829, when he wrote the following note to himself, he had become an almost perfect example of the notion that distrust of the world begins with distrust of the self:

That temptations surround us at every moment is too evident to require proof. If they cease from without they still act upon us from within ourselves, and our most secret thoughts may as surely be drawn from the path of duty by secret temptation, by the admission of evil suggestions, and they will affect our characters as injuriously as those more palpable and tangible temptations that attack our sense.

This life is a state of discipline; a school in which to form character. There is not an event that comes to our knowledge, not a sentence that we read, not a person with whom we converse, not an act of our lives, in short, not a thought which we conceive, but is acting upon and moulding that character into the shape of good or evil; and however unconscious we may be of the fact, a thought, casually conceived in the solitariness and silence and darkness of midnight, may so modify and change the current of our future conduct that a blessing or a curse to millions may flow from it. . . I shall cheat myself in preserving a good moral outward appearance to others if every thought of the heart, in the most secret retirement, is not carefully watched and checked and guarded from evil, since the casual indulgence of a single evil thought in secret may be followed, long after that thought is forgotten by me, and when, perhaps, least expected, by overt acts of evil. ${ }^{30}$ 


\section{7. \\ The End}

In June 1820, Elizabeth Morse listed the material possessions she and her husband were moving to New Haven. The list was long and impressive, the accumulation of a lifetime. There were four feather beds, three bedsteads, a cooking stove, a "large looking glass - worth $\$ 50.00$," seventeen "mahogany chairs," thirty-five cake tins, and much more. As Elizabeth packed the blue-and-white china and the "green edged" washbowl and pitcher that she labeled "mine," she was overcome with bitterness and some measure of fear. No matter how distressing the relationship with the church had been, playing the roles of minister and minister's wife had provided security and stability. The congregation had provided her family with a home for three decades. Now the Morses were going off into the unknown; the family's finances were "deranged" by debts and the loss of the parsonage and the yearly minister's salary. The children were not yet settled in the world; Finley's wife and child moved with them to New Haven while Finley, more often than not, pursued his painting career elsewhere. Unshackled from his pulpit, Jedidiah Morse set out to save the Indians; he squandered his money and his health on an effort that proved quixotic. The years in New Haven were a time of deterioration, decline, bitterness, and, ultimately, death in full measure. ${ }^{1}$

For Jedidiah Morse, the loss of his pulpit was an emotional disaster from which he never fully recovered. Soon after arriving in New Haven, he was off on a series of journeys, but his mind wandered back to Charlestown. He wrote Elizabeth that he had "seasons of depressed feelings" when he thought of the conflict with his congregation. He felt betrayed by friends. As was his habit, he saw the event as a conspiracy to be revealed. $\mathrm{He}$ referred to the loss of his pulpit as "involved in unpenetrable mystery." To the end, Morse never faced the issues involved in the breakup; at one point he stated that "the whole appears like a dream."

More than six years after leaving Charlestown he was still pursuing the debate. Perhaps the last letter he ever wrote (he died before receiving the answer) was to the Reverend William Greenough, who had served on the council that finally severed Morse's connection with the church. Apparently (Morse's letter did not survive), Morse complained that the report of the council had impugned his character. Greenough's reply was kind and flattering, but it left no doubt about his view of Morse: "I was led to consider you as a respectable useful man, as an agreeable and good preacher. I 
however confess I was sorry that a person of your abilities and hopefull piety did not confine yourself more within the limits of your office. I censured you, Sir, more, in my own mind, for what I considered as impudencies than immoralities." His dismissal from the church had touched very close to Morse's deepest anxieties. It finally resolved his double career and his neglect of parish duties. Inevitably, in his mind, this was an assault on his character and morality. ${ }^{3}$

With their finances in disarray, the Morses were clearly moving downward. They began their days in New Haven in a small house on Temple Street, near the green. The family borrowed to keep up appearances. Soon they had to mortgage the house, and eventually they sold it to Eli Whitney with an option to buy it back - they never did. This reality was a sharp contrast to Morse's persistent fantasy of a wonderful house designed by Finley. ${ }^{4}$

Money was, indeed, in short supply. Jedidiah Morse lost his job at the worst possible moment. The Panic of 1819 plunged the United States into financial chaos. Booksellers and printers, with whom Morse had many complex relationships, failed or closely skirted bankruptcy. Morse, caught in this downturn, was again called on to pay outstanding debts. Nothing was a more common subject than debts and payments in the Morse family correspondence between 1820 and 1826. In 1821, Morse made arrangements to sell all his books in Washington, D.C., Philadelphia, and New York City. He hoped that would allow him to pay all his debts, except those due family members. To keep afloat he began borrowing from his sons and selling more books. In August and October 1823, in New Haven, Morse sold more than six hundred separate lots of books and received $\$ 520.71 .^{5}$

Between 1820 and 1826, the Morses, driven by debt, turned their home in New Haven into a family workshop. Morse had published the eighth edition of the large geography in 1819 , in the midst of the struggle with his congregation. By 1823 he still owned more than one thousand copies of the original edition of forty-six hundred. In order to sell these copies, he gave it a new title, wrote a sixty-page appendix, and extolled the strange product as "nearly as valuable as a new edition-it will be ready for spring sales." Morse began doing special writing jobs for publishers such as Mathew Carey in Philadelphia, who paid Morse four hundred dollars for an assignment. This work was probably Morse's History of the American Revolution (1826). The family was also working on a gazetteer and atlas. ${ }^{6}$

All this effort required the presence of his sons. Sidney and Richard spent much of their time with their parents in New Haven in the early 1820s. Both were in the process of switching into a new field. Sidney, trained in the law, and Richard, a minister, were working their way into 
the newspaper business. With Sidney in the lead, they founded the New York Observer in 1823. But clearly their father was making great demands on their time. Richard wrote Sidney that struggling with gazetteers and geographies was oppressive: "I have at times been out of patience at the vexatious detention here a whole winter with so petty a work and could hardly help blaming father for controlling our arrangements."

Finley avoided such detentions, but was intimately tied to the New Haven home. He visited his wife and daughter often and worked on inventing a marble-cutting machine in the back yard. The family had high hopes that the machine would prove profitable, but it came to nothing. Beginning in November 1821, Finley was painting his massive portrait of the House of Representatives. His plan to display the painting and charge an admission fell flat, depressing Finley and the family. Separated from his family, failing as an inventor and painter, Finley was depressed and on the edge of despair. His father added to his gloom by subtly pressuring Finley to be more dutiful: "I see in what ways our past trails are working for our good. We shall . . . find it good for us to have been afflicted. The affections and duties we owe each other in our several relations will I trust be in future more faithfully exercised and fulfilled than they have been and our love much increased." 8

In the autumn of 1823, Finley was in New York City determined to plant himself as an artist. It was not to be; within months Finley had obtained a position in the legation to Mexico. All set to leave wife and child in New Haven and travel to Mexico, the mission was canceled at the last minute, and Finley found himself back in New Haven in the spring of 1824. In the fall, wife and child with him, he was back in New York City again. This second attempt to establish himself in New York was more successful. With great joy, he won the commission offered by the city to paint Lafayette's portrait. Packing his family off to New Haven again, he went to Washington to begin his portrait of the aged French revolutionary, a man who was to have a great impact on Finley. During the last five years of his father's life, Samuel Morse led a fragmented and unsettled existence; his parents uprooted, separated from his wife and child, and often grasping at illusionary opportunity, Finley entered his thirties in no way settled into adulthood.

So the sad little house on Temple Street gathered together and spun out Morses in what seemed like a random pattern-Elizabeth Morse and Nancy Shepard were the only constant factors. Jedidiah was absent for long stretches, campaigning to save the Indians. No one can know for sure why Morse turned to Indian policy as an issue just as he was losing his pulpit. Certainly he had a lifelong interest in the subject, but he had many such interests. His geographies discuss Indians at some length, and he was 
a member of several benevolent societies that sought to help them. In 1799, at the behest of the Society for the Propagation of Christian Knowledge, Morse and Jeremy Belknap had inspected the Scottish-supported Indian missions in upstate New York. Morse knew and corresponded extensively with at least two men who had established Indian missions, Gideon Blackburn and Joseph Badger. Finally, he seems to have shared an interest in and sympathy for the Indians with his lifelong friend and colleague, Abiel Holmes. ${ }^{9}$

Morse's involvement in "the Indian question" was a natural extension of a lifelong habit. He had always sought to have a voice in public affairs; hardly an issue arose between 1790 and 1825 that did not interest him. To the very end, he wanted to be on stage and, in the 1820 s, the fate of the Indians was a major element in the American drama. Native Americans had always fascinated white Americans. Before Americans began pouring into the West, this fascination had been anthropological and very much influenced by Enlightenment attitudes. The notion of the Indian as an innocent noble savage lay beneath the common Enlightenment desire to collect information. The Lewis and Clark Expedition, in 1803, went West with explicit instructions from Jefferson to find out as much as possible about the western tribes. Somewhat vaguely, Americans assumed that the Indians would evolve according to a widely held theory of cultural development. They would give up gradually their savage habits and take up agriculture, private property, and Christian habits such as monogamy. From this basis, they would advance in increasingly complex steps. Although many Americans thought the Indians would evolve and progress (become like whites), there was a degree of romantic regret about this inevitability. In a nation becoming intensely capitalist and competitive, the idea that the Indian would gradually assimilate into American life meant, realistically, that simplicity and innocence would be destroyed.

After 1815, the Enlightenment faith in assimilation markedly declined. As whites and Indians came into close contact, competition for land increased. The assimilationist position possessed little allure for ordinary land-hungry Americans; intellectuals coldly theorized about acculturation and Indian progress but, by 1820 , many Americans wanted the Indians removed. Talk of progress and assimilation gave way to talk of extinction. After 1820, the federal and state governments came under intense pressure to formulate a detailed Indian policy. Jedidiah Morse, aging, infirm, and out of a job, projected himself into the debate on exactly what that policy should be. ${ }^{10}$

The subject of Indian policy, in subtle ways, involved issues important to Morse personally. In Morse's mind, Indian society was nonacquisitive, agrarian, and patriarchal. It was also clear to him that modern capitalist 
society, represented by the "Indian trader," was in the process of destroying Indian society. For a man caught between an agrarian past and a capitalist present, the dilemma of the Indians was naturally affecting. Furthermore, the Indian "problem" involved the conflict of independence and dependence, autonomy and slavery. Morse, like many other Americans, believed that the Indians were one emblem of autonomy and independence, but that the advance of modern white culture threatened them with slavery and abject dependence. Morse could easily have turned to any number of issues that would have cost him less money and energy. It is possible to speculate that the Reverend Morse took up the Indian cause because the subject touched deeply rooted issues in his own psyche.

Armed with a commission from several benevolent societies and the War Department, Morse set out in May 1820 with son Richard to tour the Northwest and see the Indians' situation firsthand. As usual, Morse's plans were too grand for his resources and his health. He envisioned an extensive tour of the Northwest with Richard and, also, a tour of the South with Sidney. His health gave out at Mackinaw City, approximately half way though his northern tour. Having spent the five hundred dollars provided by the War Department, and with his life in jeopardy, Morse returned to New Haven. There, late in 1820, he drafted his report to John C. Calhoun, the secretary of war.

Morse's Report to the Secretary of War of the United States was sensitive to three interrelated issues concerning Indians and government policy. The policy toward Indians was contradictory; on the one hand it supported, often lamely, the civilization or "improvement" of the Indians while, at the same time, attempting to remove them and make their lands available for white settlement. Connected to this central issue was the problem of whites trading with the Indians. Morse understood that this trade (read whiskey) was a central cause of the Indian's degeneration into abject dependence. Finally, there was the issue of race and intermarriage. Any plan to incorporate Indians into American society implied race mixing and all the emotions connected to that issue. ${ }^{11}$

Morse's views on all three issues emerged in his Report. He took a decidedly negative view of the men who traded with the Indians. On his tour he saw a distasteful element of capitalism; repeatedly he referred to traders as immoral and as men of "poor characters." Morse's solution was government control of the traders, who, under his plan, would have to buy a trading license from the government, which could then monitor their behavior. The licensing fees would help fund the improvement and education of the Indians. On the mixing of Indian and white blood, Morse's view was also clear. Unlike many Americans, Morse had a sanguine view of the Indians' improvability. He admitted that "civilized people" would not in- 
termarry with Indians given their present level of civilization. However, Morse suggested, if the Indian were educated and adopted Christianity and the Christian notions of marriage, "the principle obstacles to intermarriage with them would be removed." To his credit, Morse's Christian beliefs in this case were inclusionary; he saw the Indians as "of one blood, with ourselves; of intellectual powers as strong, and capable of cultivation, as ours. They, as well as ourselves, are made to be immortal." To see the Indian as degenerate and inferior and to profit from their weakness was, Morse deeply believed, wrong "and highly displeasing to our Common Creator, Lawgiver and final Judge." 12

To control the influence of trade, to integrate and generally raise their status, Morse proposed that the government send "Education Families" among the Indians. His plan called for the gathering of Indians who remained east of the Mississippi into districts and the establishment of an Education Family in each district. To install this plan, the federal government would have to set aside "the existing system of operation in regard to Indians" and commit itself to "the erection of a new and more commodious and sightly fabric." Morse persistently claimed that government policy had to build on an entirely new foundation. ${ }^{13}$

The central element of this new foundation was the Education Family. This was the device that would improve and civilize the Indians. It called for the construction of a village, or extended village, that bore a striking resemblance to the idealized New England town Morse celebrated in his geographies. The village would be headed by a minister to teach Christianity to the Indians and to set a proper moral tone for everyone, especially traders. Below the minister there would be an "association of families." The families would be chosen to include all the necessary skills: school teachers, farmers, and "women capable of teaching the use of the needle, the spinning-wheel, and the loom." The system put special emphasis on the Indian female and the elevation of her moral position in the community. Morse was appalled by the "present degraded state" of Indian women and declared that it should be "a primary object" of government policy to raise their status. Slowly, the Indians would move from their "uncivilized" state and embrace Christianity, farming, and the habits of white Protestant families. Thus improved, Indians and whites would begin to intermarry and the Indian would be saved from destruction. ${ }^{14}$

The Report was destined to convince hardly anyone. Confusing and clearly based on skimpy evidence, it had, as we shall see, little influence. Yet the Report revealed much about Morse's values. Barely submerged in its confused style and organization was a deep bias against capitalism and laissez-faire individualism. Represented by the trader, these new forces were, in Morse's mind, like guns cocked, loaded and aimed at helpless 
Indians. To defend the Indians, Morse evoked paternalism and premodern hierarchical structures. The Indians, in order to save them, had to be made into children. Much of the Report was subtly devoted to showing that the Indians were "without the privileges of self-government": "They are weak, and ready to perish; we are strong, and with the help of God, able to support, to comfort and to save them." The process of educating the Indians would parallel "the manner in which we educate our own children." 15

Once infantilized, the Indians required paternalism, not neglect. Morse claimed that they deserved "kind paternal treatment," and that if it was not forthcoming, "our national character must suffer in the estimation of all good men." The federal government must take complete control of their red "children" and exercise over them a government that "should be in its nature parental—absolute, kind and mild, such as may be created by a wise union of a well-selected military establishment, and an Education Family: The one possessing the power, the other the softening and qualifying influence."16

In sum, Morse called for the destruction of Indian tribal culture and all that made Indians what they were in order to save them. Their salvation was the salvation offered by the image of the rapidly disappearing New England town with its agrarian base, Christian morality, and hierarchical and patriarchal patterns of obedience. Confronted with the imminent destruction of premodern tribal societies, Morse suggested that these societies be salvaged by molding them into the shape of another premodern tribal society that was also rapidly expiring. Morse found the solution to a contemporary problem in the virtue and morality of an idealized past.

Morse, like most humanitarian reformers, saw his efforts on behalf of the Indians as preservative. He repeatedly lamented the imminent destruction of the northwestern tribes at the hands of capitalism. This reflected a certain blindness in Morse; his plan quite clearly called for the destruction of Indian culture and the construction in its place of a new culture based on Protestant values and secular individualism. A reviewer in the North American Review noted that Morse would not allow any basic element of Indian life (language, landholding in common, manners, religion, and traditions) to survive and concluded that to follow Morse's suggestions would cause the ultimate destruction of the Indians. Jedidiah Morse had great sympathy for the Indians, but ultimately his sympathy was as deadly as the most virulent animosity.

All this testifies to a profound limitation in Morse's thought and in Enlightened humanitarianism in general. Simply put, Morse could not imagine a world based on cultural pluralism. He could not conceive of the Indian tribes evolving in ways fundamentally different from the white man. It is possible to suggest that at the core of Morse's value system was 
a profoundly uniform vision of progress that was a not particularly thoughtful amalgamation of Christianity and the Enlightenment. It saw all the world's cultures succumbing to rational Christian values. In this vision, the millennium would feature the disappearance of all difference (error); Indians, Unitarians, Illuminati, and Frenchmen would all freely renounce their ways and assemble beneath the banner of a triumphant evangelical Christian civilization. ${ }^{17}$

The plan proposed in the Report obviously needed the approval and support of the federal government. With draft in hand, Morse went to Washington late in 1820, but was put off by Calhoun for a year. In 1821, Morse waited in Washington for the Committee on Indian Affairs to request the report. He believed the committee would consult with him and publish the report-they did neither. Disappointed, Morse returned home, and in April he published the Report at his own expense. This expensive vanity on the father's part angered Sidney, who begged his father not to waste any more of the family's scarce resources printing books on Indian affairs: "We shall never get rid of our embarrassments so long as this is kept up."18

The public and government rejected not only Morse's Report, but also his plan to create a benevolent society to establish and monitor Indian policy. Named, in the finest nineteenth-century style, the American Society for Promoting the General Welfare of the Indian Tribes within the United States, it was, bluntly, a strange organization. According to the society's constitution, which Morse wrote, the government would turn over to the society, an extralegal entity, the job of forming Indian policy. Morse set out to create the society by appointing the thirteen-member board, which would have the real power in the society, but many, including John Adams, politely declined to serve. Morse called meetings of the society in December of 1822 and 1823 and in February 1824. Attendance was small; the society excited no public interest, and it quietly dissolved. Morse's last crusade amounted to very little; it left him with his health broken and the undeniable taste of defeat and humiliation. ${ }^{19}$

During their years in New Haven, the Morse family experienced, as they had before, the nearness and reality of death. The period began with news of the deacon's death on December 29, 1819, in Woodstock. Apparently Morse heard of his father's death first from Timothy Dwight, and soon after from his wife. Morse immediately understood that "the event will produce a great change in the family at Woodstock." In little more than a year, death came again to the Morse family. Lucretia Morse gave birth to her second child, Elizabeth Ann, in March 1821. Both a doctor and a midwife attended to Lucretia - the birth was clearly a hard one. Lucretia was unable to nurse the child, and the assembled expertise (including her mother-in-law) decided that the child should be "raised by 


\section{THE END}

hand." Within days the child began to fail: "We fear canker of the bowels." The family lavished medical attention on the infant, but to no avail. Jedidiah wrote Samuel of the efforts being made, but in the end his fatalism rose again to the surface. He claimed that all was being done that could be done but, in the end, "we can leave it comfortably in the hands of God and leave it to his disposal." He also wrote that "if it grows worse we shall baptize it, otherwise we shall leave it till your return." Referring to the newborn as "it" illustrated the degree to which Morse had become desensitized to infant death. By seeing the infant as an object, he could keep grief at arm's length. Elizabeth Ann died in late March $1821 .{ }^{20}$

Lucretia was never a strong woman, and childbirth weakened her even more. In January 1825, she gave birth to a son, James Edward Finley; again it was a hard birth, and she took immediately to bed. On February 7,1825 , she was still recovering when she suddenly died from what the family doctor called an incurable "affliction of the heart." Jedidiah Morse witnessed the death and wrote his son that Lucretia "fell back with a momentary struggle on her pillow, her eyes were immediately fixed-the paleness of death immediately overspread her countenance, and in five minutes more, without the slightest motion, her mortal life terminated." Jedidiah advised the absent husband to think of Jesus in the house of Martha and Mary, to think of Jesus who sits at the right hand "of his Father" and pleads the cause of afflicted children. Finley was in Washington, D.C., painting the portrait of Lafayette. ${ }^{21}$

Surely these tragedies gave Jedidiah Morse a sharper sense of his own inevitable death. He was a physically weak man his entire life. It is impossible to pinpoint the exact nature of this weakness, but he often claimed that he suffered from "cholera morbus," or general gastrointestinal distress. It is not unreasonable to suspect that Morse had ulcers or some related condition. Late in life, after 1820, he often complained of numbness in his hands and feet, and he and his wife suffered from what Elizabeth call "Erosepelus." This was almost certainly erysipelas, a streptococcal infection of the skin, that featured a bright red inflammation and was very debilitating. What eventually proved fatal, however, is not known. Jedidiah Morse died on June 9, 1826. According to Sidney Morse's testimony, his son, Samuel, was at the bedside and asked his father, "Have you any doubt of the truth of the doctrines you have preached"? Morse replied, "Oh, no! They are the doctrines of the Bible. The Savior, whose honor you have protected, will not now desert you. Oh no! he gives me a foretaste of heaven." Under the circumstances, the question was more interesting than the answer. ${ }^{22}$

Morse's will was eloquent testimony to the financial failures of his last seven years. As was common, Morse made symbolic bequests, "tokens" as he called them. His three sons received fifty dollars, and Morse noted that 
each had already received "his portion" of the father's estate. For Samuel, his portion was the money that financed his education in England. To even things out, Morse had turned over the copyrights to his books to Richard and Sidney. They, however, were required to pay Elizabeth onethird of the income from their book sales as long as she lived. Susan Walker Morse received a pocket Bible and a silver cup with her grandfather Morse's name engraved on it. Anne "Nancy" Shepard, Elizabeth Newall, and Martha Edes received fifty-dollar bequests, "for their fidelity and kindness in the discharge of their duties." After paying these bequests, the remainder of his estate went to his wife. ${ }^{23}$

There was, however, less than nothing for Elizabeth to inherit. Sidney Morse, executor of the estate, presented an inventory of Morse's assets and debts. The estate's assets came to $\$ 7,490.30$, whereas the debts amounted to $\$ 14,986.46$. Jedidiah Morse died owing the printers and booksellers, Samuel Wadworth and Sherman Converse, slightly more than three thousand dollars, and Eli Whitney almost one thousand dollars. The rest he owed to members of the family: Samuel, $\$ 1,383.61$; Sidney, $\$ 1,056.10$, Richard, $\$ 1,385.89$, and Nancy Shepard, $\$ 1,258.10$. The saddest note was surely the debt to his lifelong servant, to whom Morse bequeathed fifty dollars for her "fidelity." 24

Jedidiah Morse died with his family in financial and emotional disarray. Sidney and Richard were unmarried and still struggling to establish the New York Observer. Both Elizabeth and Jedidiah were concerned about their sons' unmarried status and uncertain financial position. Finley may have caused the deepest anxieties. Widowed, he left his children in New Haven and pursued his painting career in New York City. Letter after letter, especially in 1826, apologized to his aged mother for imposing on her. He routinely justified being separated from his children by claiming he was working hard making his way in the world. In November 1826, he even proposed to his mother that she keep the children while he returned to Europe for further education. Elizabeth apparently did not support his plan. Finley did not return to Europe until after his mother's death on May 28, 1828. In the months before she died, he was desperately attempting to place his children with other members of his and Lucretia's family. Susan, for example, was taken in by Lucretia's sister, Susan Pickering, in Concord, New Hampshire. About a year before she died, Elizabeth summarized her own life in the wake of her husband's death: "At age 61 years I have three little motherless children to take care of besides three young men all without wives who have never yet been from under my care at home or abroad." 25

Thus, Jedidiah Morse left behind him a dislocated and fragmented family. His indomitable wife held the fragments together for a short while, 


\section{THE END}

but on her death it shattered for good. If the word home means more than merely a house, Jedidiah Morse never had a home after he left Woodstock in 1778. Many Americans found homes, actual and psychological, in the new liberal America, but Jedidiah Morse was never one of them. The Christian republican values that Morse associated with this father and the past exercised a tyranny over him that proved unshakable. He often donned a mask and became the champion of the past, defender of the faith of the fathers. This was essentially a public role and he played it well. During his lifetime he was, for many, the champion of orthodoxy, the ultimate conservative in an era of change and dislocation. Yet his conservatism was only one of the masks he wore. A more private mask, one that Morse could never acknowledge even to himself, was that of a capitalist individualist who dealt in contracts, deadlines, and cash values. It was abundantly clear that these roles clashed. His father, his church, and some of his business associates knew both the republican and the liberal Morse. As he grew older, the conflict became more severe; the world around him insistently demanded that he acknowledge his bifurcated soul. He resisted these demands by creating an imaginary world of conspiracies and conflicts, a world in which he could deflect the attacks on his character and play the part of soldier in the army of the Lord. He died playing the role he had rehearsed so hard and long. 



\section{Epilogue}

Psychological interpretations of individuals like Jedidiah Morse must, by their very nature, be speculative. Jedidiah Morse, I have argued, was bedeviled by an internal conflict, or identity diffusion, that he was unable to acknowledge even to himself. In the mass of existent manuscript material left by Morse, there are very few examples of personal introspection. What little introspective writing Morse did has been fully cited and interpreted in the course of this book. The view of Morse as an anxious and divided man who engaged in moments of conspiracy thinking and "totalism" has been built on collateral evidence and inference.

Yet in Morse's case, there remains one kind of evidence historians rarely possess. Samuel F. B. Morse painted five important representations of his father. Commonly, a biographer may have paintings or photographs of his subject, but rarely are they the product of a near relative who may openly, or inadvertently, leave important clues about the subject on the canvas or film. The paintings by Samuel are also valuable because they were painted over a significant time span-from 1808 to 1823 . This creates the possibility that the paintings reveal change and evolution in both the subject and the painter. ${ }^{1}$

What, if anything, do the paintings reveal? One obvious response is to note that Jedidiah Morse was clearly presented as a cleric only in the 1823 portrait, several years after he had lost his pulpit. This suggests that the family understood the truly devastating consequences of the final chapter in the conflict between Jedidiah and his congregation. In portraying his father in pastoral dress, Samuel may have been giving expression to the barely repressed family wish to have Morse regain his pulpit. Placing the father in the gallery above the House of Representatives supports this view; the Reverend Morse has magically regained the "pulpit," with America, symbolized by its representatives, spread out beneath him.

The early paintings are, however, more meaningful and complex. Certainly they reflect Samuel's sense that his father's identity was far removed from his clerical profession. They are paintings of a scholar's family and a scholar at work in his study - with the result of his labors arrayed about him. The books, the geographical system of texts and gazetteers, fully share the paintings with Morse and his family.

These two early works become meaningful only in the fullest imagined context. They present a world that contrasts sharply with that of Deacon 


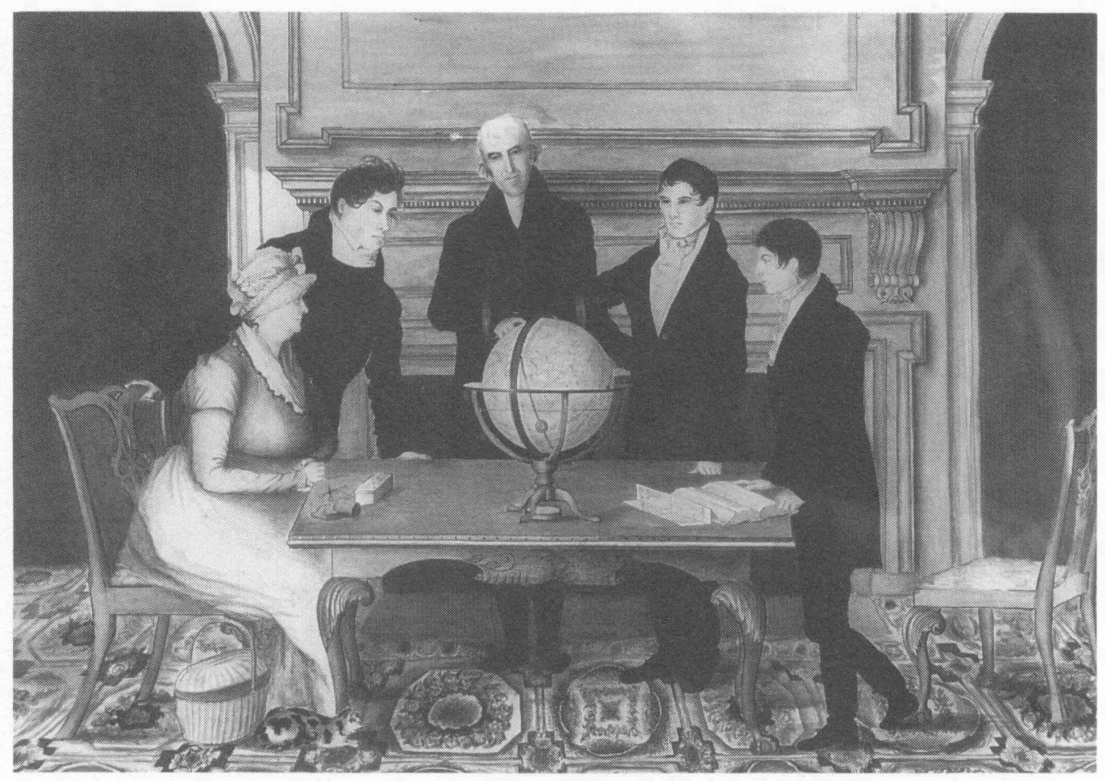

Fig. 1. Samuel F. B. Morse, Morse Family Group, 1809. Watercolor on paper, 12 by 15 inches. Courtesy of the Smithsonian Institution, National Museum of American History.

Morse and the family home in Woodstock. Although we can only imagine that world, Samuel knew it well. Rural life was not only simpler, it was dirtier, more brutal, and bloodier. The deacon and Jonathan Morse were laborers; strong men who responded to nature and nature's demands. The deacon, as a farrier, neutered thousands of animals in his life. This was a process, bloody and brutal, that city dwellers saw only rarely, if at all. The deacon no doubt also shoed horses and other working animals. In contrast, the world of Jedidiah Morse in Charlestown was genteel, refined, even effete.

The Morse Family Group (c. 1809) suggests the extent to which Jedidiah lived in a world different from that of his father. The fancy floral carpet serves as a base on which Finley builds the picture. The Chippendale furniture, the mantle and fireplace are elaborate and clearly the possessions of an affluent family. The picture conveys the sense that the production of knowledge is the family business. Even Elizabeth Morse seems included in the process; but she is separated from the male group by the presence of her sewing tools and basket, time-honored symbols of domesticity. The younger males, Finley on the left, Sidney and Richard on the right, mimic 
EPILOGUE

145

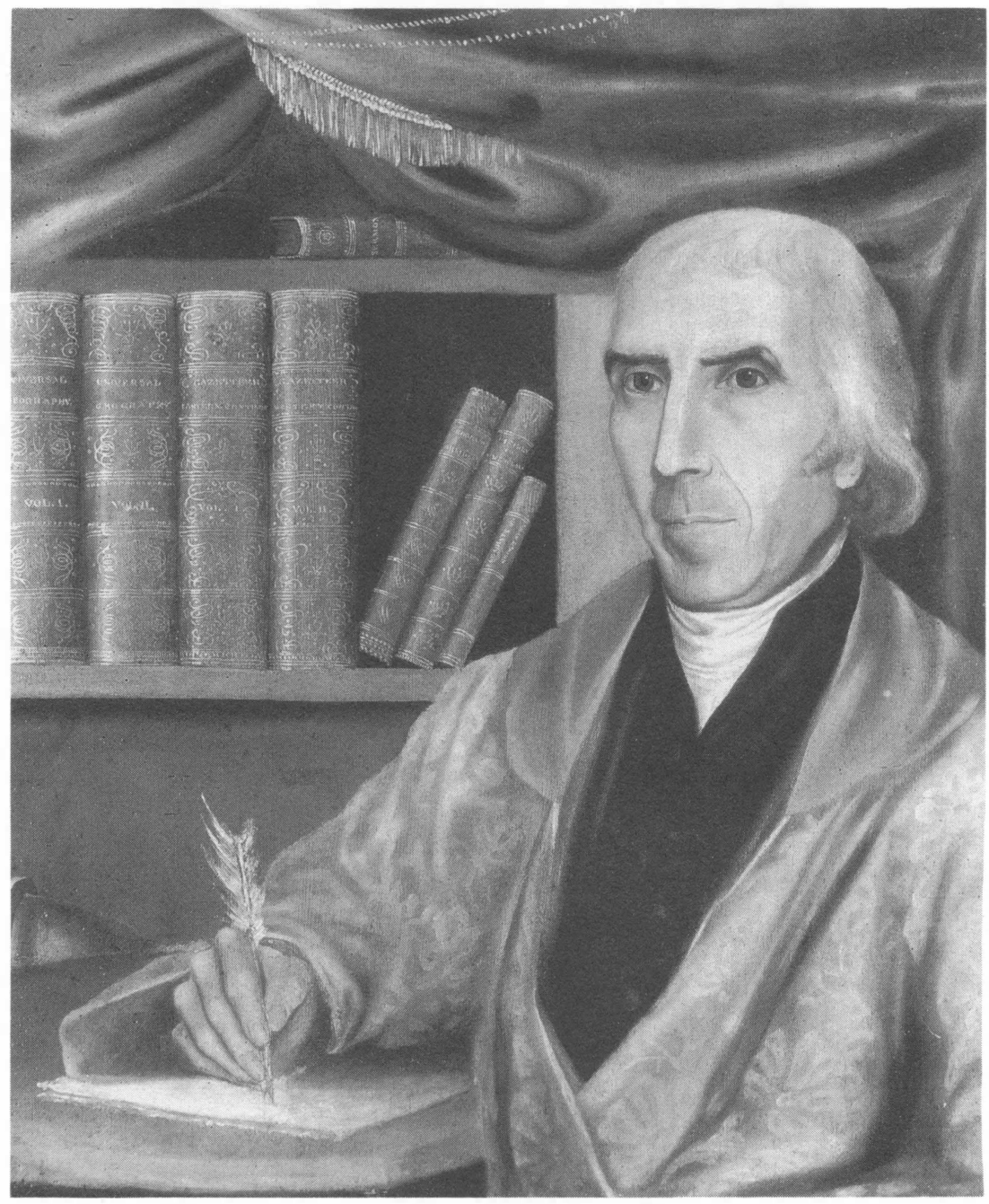

Fig. 2. Samuel F. B. Morse, The Reverend Jedidiah Morse, 1809. Oil on panel 28-3/4 by 22-7/8 inches. Courtesy of Yale University Art Gallery (gift of Helen E. Carpenter). 


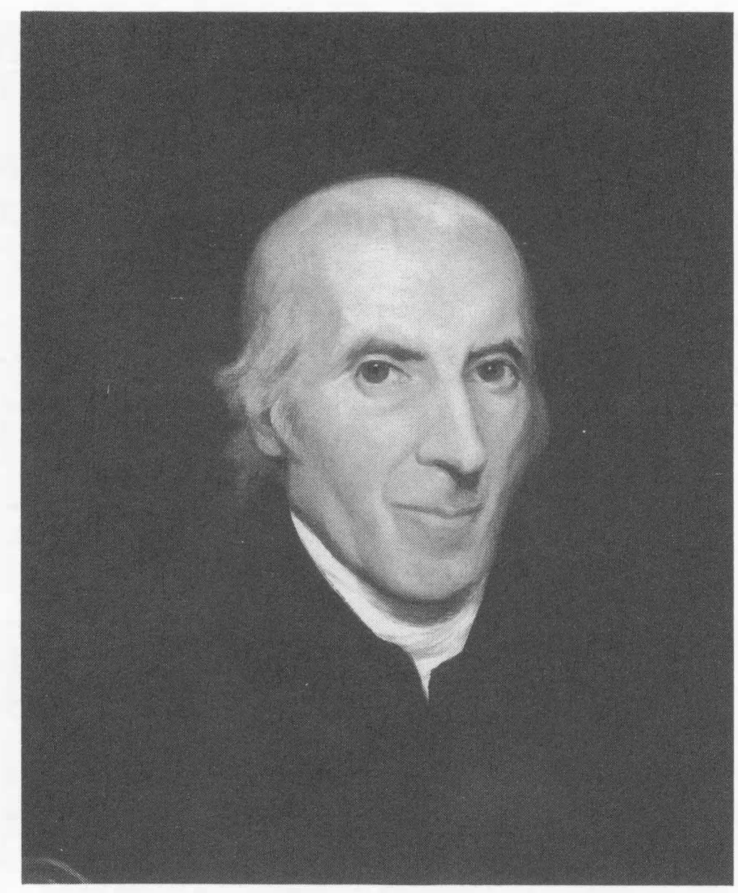

Fig. 3. Samuel F. B. Morse, The Reverend Jedidiah Morse, 1816-17. Oil on canvas $29-1 / 2$ by 24 inches. Courtesy of Yale University Art Gallery (bequest of Josephine K. Colgate).

the gray-haired father. They seem like men-of-knowledge in training. This painting was produced very close to the period in which Finley, fresh out of Yale, was forced to work for a bookseller. He was to make his living in the clean and tidy world of the retail book trade. The globe and the geography text, with map unfolded, are tools of the trade. Although the family goal is clearly the comprehension of nature and space, the only sign of nature itself is the house cat at Mrs. Morse's feet.

Sometime in the 1820s, Samuel presented the watercolor of his family to Nancy Shepard, who gave it to the Hovey family in Charlestown just prior to her death. Returning to Charlestown in 1856, after a long absence, Samuel came across the painting while visiting the Hoveys. Acting as his own critic, he remarked that his father and, especially, his mother were "good likenesses." The figure of Richard was "tolerable," but he did not like his rendition of himself and Sidney. He also noted, amazingly, that the painting was incomplete; he had never painted the legs on the 


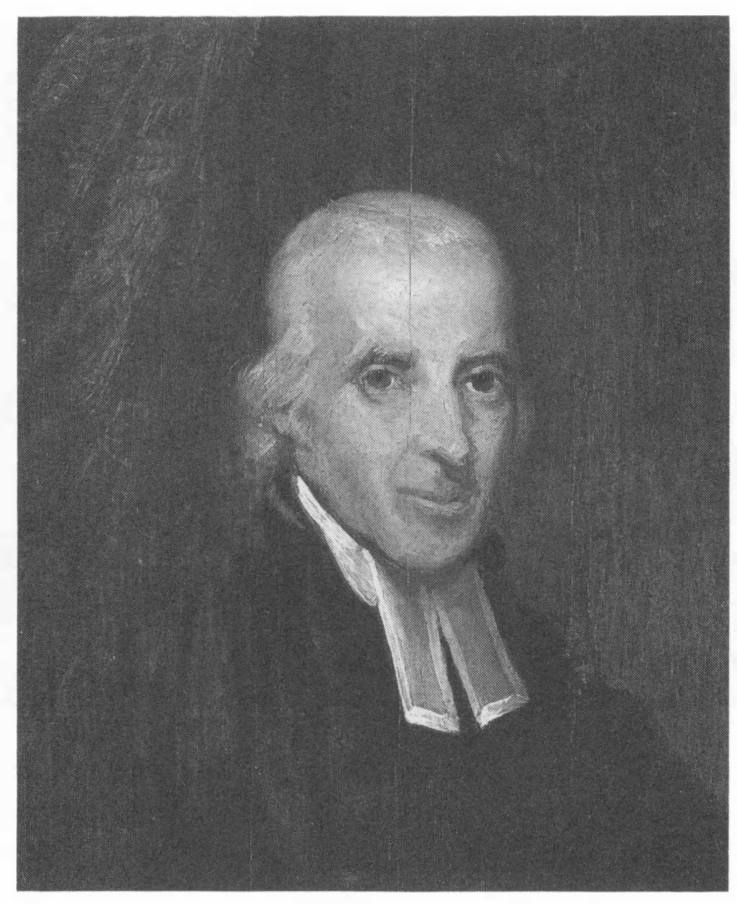

Fig. 4. Samuel F. B. Morse, The Reverend Jedidiah Morse, 1823. Oil on panel, 10 by 8 inches. Courtesy of Harvard University Art Museums (Fogg Art Museum; bequest of Grenville L. Winthrop).

figure of his father. Apparently, at some point after 1856, someone corrected the oversight. Were the missing legs merely the result of Samuel moving on to other projects? Or did the oversight have psychological implications? Did Morse the young painter gain some measure of revenge against his oppressive father by rendering him legless? Did young Samuel mean to suggest that his father was in some sense incomplete, unfinished, or incapable as a person? No matter what one thinks about the Reverend Morse's missing legs, it seems very strange that Samuel never found the time between 1809 and his father's death to add them. ${ }^{2}$

The second work from this period contains many of the same themes as the family watercolor. The complexity, luxuriousness, and refinement of the scene dominate. Jedidiah Morse is the image of the affluent scholarauthor. He sits at his table in his gold-and-red gown producing more words, more knowledge; the rich colors of the gown are repeated in the curtain fringe and in the spines of the books. The geographies fully share 


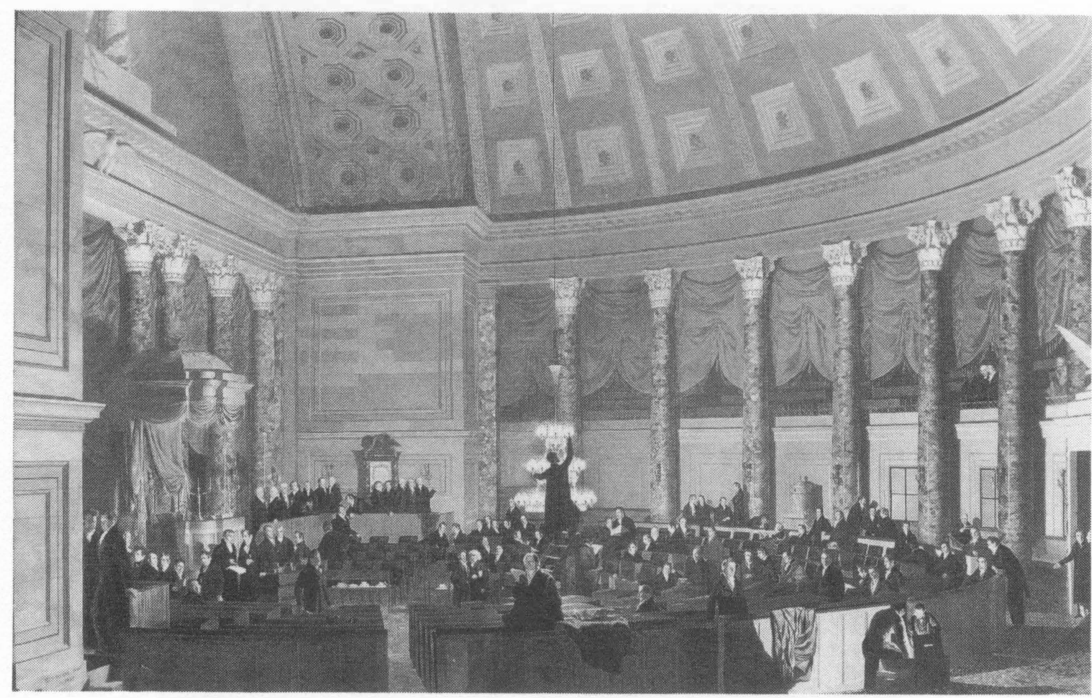

Fig. 5. Samuel F. B. Morse, The Old House of Representatives, 1822-23. Oil on canvas, $86-1 / 2$ by $130-3 / 4$ inches. Courtesy of the Corcoran Gallery of Art, Washington, D.C.

the painting with Morse, whereas the book of sermons seems laid aside, neglected on top of the shelf. As a worker, it is clear what Morse has produced; he has made books that as commodities are grand and more than a little intimidating. The painting suggests that Samuel fully and completely identified his father with these books.

These early paintings give substance and texture to the deacon's criticism of his son. They are testimony to the son's opulent life and neglect of pastoral duties. Nowhere in either work is there even an intimation of piety. The Jedidiah Morse portrayed is affluent, scholarly, inclined to luxury, and slightly effete. If he fits a stereotype, it is the stereotype of the enlightened scholar, not the pious divine. It is not until 1823 that the minister (without pulpit) appears on canvas.

The two portraits from 1816-17 and 1823 are clearly not as biographically complex as the earlier work. By 1816 Samuel had become a vastly more mature artist, but this may have served to temper his youthful feelings about his father and family. The robes, books, furniture, and drapery disappear, and all that is left is the face. His father's body is virtually absent from the 1816 portrait, and the body appears in 1823 only as a depressing blackness beneath the clerical collar. Certainly even the most casual observer would note the similarity in the treatment of the eyes in the 
portraits of his father. In all three, the eyes are enormous and piercing. In the two later portraits they stare knowingly, even smugly, at the viewer and the painter. However, in the portrait from 1810, the eyes cannot, or do not, look out at the viewer/artist. They seem to see something of the viewer's left, they seem reluctant to conf ront the artist.

The most pictorially complex of all the works by Samuel Morse in which his father appears is The House of Representatives. Finished in early 1823 , it is among Morse's best and most intriguing paintings. Jedidiah occupies a marginal but important position in the visitor's gallery. Next to Morse stands Benjamin Silliman, Samuel's professor at Yale. To Silliman's left appears a shadowy, unidentifiable figure (the deacon?). In the next bay to the right stands Petalasharo the Pawnee chief, a celebrity in the Washington community. As part of a large diplomatic mission from the Indian tribes, Petalasharo had captured the fancy of many in the capitol. His image as a humane and benevolent Indian was based on his rescue of a Comanche woman from being burned at the stake. It seems likely that Morse placed him in the gallery as a symbol of innocence (not savagery) as the House debated Indian policy. If this is so, then perhaps Morse represents Religion and Silliman, Science. Thus, the three, Innocence, Religion, and Science, preside over the Democracy below.

This would be a major resurrection for Jedidiah Morse. There can be little doubt that 1822 was a humiliating year for him. His trip had been cut short, and he had idled away for months in Washington hoping to have his report on the Indians read and heeded. It was not. Eager to sway national policy, Jedidiah was ignored as the democracy began the process of stripping the Indians of their land. In this light, putting Jedidiah in the gallery as some sort of moral steward when both the son and father knew that the father's cause had failed seems at best quixotic. Yet it certainly suggests the degree to which denial was part of Morse family life. In reality, the elderly minister in the gallery was a failure. His crusade to save the Indians was lost, his pulpit and reputation as a minister were gone, and his desire to rise above the massed democracy as a moral shepherd had, in reality, collapsed. But wishing could make it so. 



\section{Notes}

\section{Abbreviations}

AAS American Antiquarian Society, Worcester, Massachusetts.

AG Jedidiah Morse, Jr., The American Geography; or, A View of the Present Situation of the United States of America.

CHS Connecticut Historical Society, Hartford.

EM Elizabeth Breese Morse.

HSP Historical Society of Pennsylvania, Philadelphia.

JMj Jedidiah Morse, Jr.

JMs Jedidiah Morse, Sr.

LC Samuel F. B. Morse Papers, Library of Congress, Washington, D.C.

NHHS New Hampshire Historical Society, Concord.

NYHS Morse Family Papers, New York Historical Society.

NYPL Jedidiah Morse Papers, New York Public Library.

SFBM Samuel F. B. Morse.

$W M Q \quad$ William and Mary Quarterly.

Yale Morse Family Papers, Manuscripts and Archives, Yale University Library, New Haven, Connecticut.

\section{Introduction}

1. Lucy Osgood to William B. Sprague, June 4, 1860, in William B. Sprague, The Life of Jedidiah Morse, D.D. (New York, 1874), 303-4.

2. Jedidiah Morse has usually been seen as a religious figure, central to understanding the religious conflicts in New England in the early Republic. Sprague's biography cited above was financed by the Morse family. It has been supplemented by two twentieth-century biographies: James K. Morse, Jedidiab Morse: A Champion of New England Orthodoxy (New York, 1939) and Joseph W. Phillips, Jedidiah Morse and New England Congregationalism (New Brunswick, N.J., 1983).

3. The literature on republicanism and liberalism in the early national period is enormous. I have found helpful Lance Banning, "Jeffersonian Ideology Revised: Liberal and Classical Ideas in the New American Republic" and Joyce Appleby, "Republicanism in Old and New Contexts," both in WMQ, 3d ser., 43 (1986); American Quarterly 37 (Fall 1985) was devoted entirely to republicanism in American Life; Issac Kramnick, "Republican Revisionism Revisited," $A H R \quad 87$ (June 1982); Robert Shalhope, "Republicanism and Early American History," WMQ, 3 d ser., 39 (1982); Joyce Appleby, Capitalism and the New Social Order: The Republican Vision of 
the 1790s (New York, 1984); and Drew R. McCoy, The Elusive Republic: Political Economy in Jeffersonian America (Chapel Hill, N.C., 1980). Two brief general accounts of the period have been especially helpful: Gordon Wood, "Introduction," in The Rising Glory of America, 1760-1820, ed. Gordon Wood (New York, 1971) and Lewis Perry, Intellectual Life in America: A History (Chicago, 1984), esp. chap. 4. Finally, I have been influenced by Steven Watts, The Republic Reborn: War and the Making of Liberal America, 1790-1820 (Baltimore, 1987). Although Watts specifically excludes Federalists such as Morse from his work, I find his views on the interrelationship between republicanism and liberalism very helpful and convincing; see especially p. $x v-62$.

4. Nathan O. Hatch, The Sacred Cause of Liberty: Republican Thought and the Millennium in Revolutionary New England (New Haven, Conn., 1977), esp. chap. 3-4.

5. One of the best descriptions of the demographic, economic, and social revolutions during and after the Revolution is in Robert A. Gross, The Minutemen and Their World (New York, 1976), esp. chap. 7, "A Bridge to the Future." Gross describes Concord, Massachusetts, during the revolutionary era. Concord and Woodstock, Connecticut, share many of the same characteristics. Also, Gordon Wood, "Introduction," 8-12.

6. Wnod, "Introduction," 8-10; Perry, Intellectual Life in America, chap. 4; James Banner, Toward the Hartford Convention: Federalists and the Origins of Party Politics in Massachusetts, 1789-1815 (New York, 1970), 190-200.

7. Erik Erikson, "Wholeness and Totality," in War: Studies from Psychology, Sociology, Anthropology, ed. Leon Bramson and George W. Goethals, 119-31 (New York, 1968); Erik Erikson, Identity: Youth and Crisis (New York, 1963), 84-85 and Watts, Republic Reborn.

8. Michael Zuckerman, "The Fabrication of Identity in Early America," $W M Q, 3 \mathrm{~d}$ ser., 34 (1977): 192-94; Anthony F. C. Wallace, "Identity Processes in Personality," in Cognition, Personality and Clinical Psychology, ed. Richard Jessor and Seymour Fishbach, 62-89 (San Francisco, 1967) and Anthony F. C. Wallace and Raymond Fogelson, "The Identity Struggle," in Intensive Family Therapy, ed. Ivan Baszoumenyi-Nagy and James Franco, 365-406 (New York, 1965). I agree with those who suggest that establishing a firm identity was easier in premodern, agrarian societies. As liberal capitalism evolved, the process of creating a whole and healthy identity became more problematical. The growth of urban society, the increase in cash transactions between relative strangers, the increasing number of roles played by an individual (parent, consumer, producer, believer, son/daughter), the flux that characterized established roles (such as minister), and other factors made it very difficult to establish wholeness in an Eriksonian sense. Instead, a liberal capitalist world imposed the necessity of establishing separate, of ten conflicting, masks that could be donned and discarded as needed. For historians who have dealt with this issue, see Charles Sellers, The Market Revolution (New York, 1991) and Watts, Republic Reborn. 
9. Zuckerman, "Fabrication of Identity," 192-94; and for the idea of a purified identity see Richard Sennett, The Uses of Disorder: Personal Identity and City Life (New York, 1970), 8-11. American historians have engaged in an important dispute concerning the nature of the jeremiad. It should be clear that I find Perry Miller's view as very helpful, not only in understanding Jedidiah Morse, but in understanding the social functions of his sermons-jeremiads. In the various attempts to analyze the jeremiad, the emphasis has been on their social role, or collective impact. I am unaware of any attempts to investigate fully the relationship between the jeremiad and its particular author. Obviously, the psychological and intellectual state of the individual author influenced the making of a jeremiad (writing and speaking). In chapter $4 \mathrm{I}$ have attempted to show how Morse's jeremiads grew, in part, out of circumstances in his own life. On the jeremiad, see Perry Miller, "Errand into the Wilderness," in Errand into the Wilderness, by Perry Miler, 1-15 (Cambridge, Mass., 1956) and Perry Miller, The New England Mind: From Colony to Province (Cambridge, Mass., 1952), chap. 2. For an opposing view, see Sacvan Bercovitch, The American Jeremiad (Madison, Wisc., 1978). Finally, for a more recent discussion that supports and extends Miller's views, see Theodore Dwight Bozeman, To Live Ancient Lives: The Primitivist Dimension in Puritanism (Chapel Hill, N.C., 1988), 298-343. For the role of the sermon in New England culture to 1800, see Harry S. Stout, The New England Soul: Preaching and Religious Culture in Colonial New England (New York, 1986).

10. JMj to Dear Friend and Brother, Mar. 1923, Yale; Zuckerman, "Fabrication of Identity," 192-96 and Erikson, Identity: Youth and Crisis, 84-85 and Erik Erikson, Childhood and Society, 2d ed. (New York, 1963), chap. 8, "Reflections on the American Identity." Erik Erikson has stated that "when the human being, because of accidental or developmental shifts, loses an essential wholeness, he restructures himself and the world by taking recourse to what we may call 'totalism.' It would be wise to abstain from considering this a merely regressive or infantile mechanism. It is an alternate, if more primitive, way of dealing with experience and thus has, at least in transitory states, a certain adjustment and survival value." Erikson, "Wholeness and Totality," 124.

\section{Woodstock and Deacon Morse}

1. In sketching out the history of Woodstock, I have drawn on several local histories. Most useful are Clarence Bowen, The History of Woodstock Connecticut . . Genealogies of Woodstock Families (Norwood, Mass., 1926) and Ellen D. Larned, History of Windham County, Connecticut (Worcester, Mass., 1874).

2. Larned, History of Windham County 1:487-90.

3. Bowen, History of Woodstock, 1:80-85; Larned, History of Windham County 1:51-55.

4. Bowen, History of Woodstock, 1:35-38; Larned, History of Windham County 1:37374, 2:396-401. The literature on the fragmentation of New England churches and the Great Awakening is enormous. See Richard L. Bushman, From Puritan to Yan- 
kee: Character and Social Order in Connecticut, 1690-1765 (Cambridge, Mass., 1967); Sidney E. Ahlstrom, A Religious History of the American People (New Haven, Conn. 1972); C. C. Goen, Revivalism and Separatism in New England, 1740-1800 (New Haven, Conn., 1962); and for an essay that disputes the importance of the awakening, see Jon Butler, "Enthusiasm Described and Decried: The Great Awakening as Interpretative Fiction," Journal of American History (Sept. 1982): 305-25.

5. Larned, History of Windham County 1:450-61, 466-68.

6. Ibid. 1:499-509.

7. An excellent account of the New England minister and the nature of his career is Donald M. Scott, From Office to Profession: The New England Ministry, 1750-1850 (Philadelphia, 1978).

8. Bruce C. Daniels, "Economic Development in Colonial and Revolutionary Con-. necticut: An Overview," WMQ 37 (July 1988): 432. See also Bruce C. Daniels, Fragmentation of New England: Comparative Perspective on Economic, Political and Social Divisions in the Eighteenth Century (Westport, Conn., 1988).

9. Goen, Revivalism and Separatism, 228-29.

10. Larned, History of Windham County 2:100-102; Bowen, History of Woodstock, 305-7.

11. The grandson, also named John, passed on the memories of his grandfather directly to Clarence Bowen. Bowen, History of Woodstock, 1:212.

12. Woodstock Church Records, vol. 3, CHS.

13. The portrait of Leonard is drawn from Clifford K. Shipton, Sibley's Harvard Graduates (Boston, 1970), 14, 450-55 and Charles Royster, A Revolutionary People at War (Chapel Hill, N.C., 1979), 170-74.

14. Letter to Samuel Webb, quoted in Shipton, Sibley's Harvard Graduates, 14, 454.

15. Woodstock Church Records, vol. 3; Shipton, Sibley's Harvard Graduates, 454-55. In 1860 , the pastor of Leonard's church published a short history of the church in which he claimed Leonard had been dismissed from the army and had killed himself as a result. L. Grosvenor, History of the First Congregational Church and Society of Woodstock, Connecticut (Worcester, Mass., 1860), 17.

16. Bowen, History of Woodstock 7:487-88.

17. The reseating of the church and petition are in ibid. 7:616.

18. Connecticut Probate Records, vol. 3: 111-13, Pomf ret County Courthouse, Pomf ret, Connecticut (hereaf ter cited as Connecticut Probate Records [Pomf ret]).

19. Woodstock Land Records 1:335-36, Woodstock Town Hall, Woodstock, Conn.

20. This portrait of Jedidiah, Sr., is drawn entirely from Jms, Birthday Reflections of Deacon Jedidiab Morse of Woodstock, Conn. (Providence, R.I., 1901). Morse produced this on July 19, 1810, his eighty-fourth birthday.

21. Woodstock Land Records 4:300; Connecticut Probate Records (Pomf ret), 13:42-43. Obviously Jedidiah, Sr., followed the pattern set by his father. He sold land to the eldest son to bind him to the area and left the estate to the same son who could then reassemble the real estate into a sizable and profitable whole. While Jedidiah, Sr., purchased his land very near his wedding day, Jonathan made his purchase from his father eight years before marrying Azubah Lyon in 1780. 


\section{To Yale and the World}

1. Richard C. Morse to William B. Sprague in Sprague, Life of Jedidiab Morse, 284-85.

2. Daniel Vickers, "Competency and Competition: Economic Culture in Early America," WMQ, Jan. 1990, 4-29.

3. JMj, The American Geography; or, A View of the Present Situation of the United States of America (Elizabethtown, N.J., 1789), 221.

4. Edmund S. Morgan, The Gentle Puritan: A Life of Ezra Stiles, 1727-1795 (Chapel Hill, N.C., 1962), 375-80.

5. Ibid., 310-20.

6. Ibid., 331-32; Brooks Mather Kelley, Yale: A History (New Haven, Conn., 1974), 93-96.

7. Jonathan Trumbull to Col. Samuel McCellan, Apr. 7, 1779, NYPL; Kelley, Yale: A History, 97-98, 101-4.

8. Morgan, Gentle Puritan, 367-68; Kelley, Yale: A History, 100-102.

9. Kelley, Yale: A History, 100-107; Morgan, Gentle Puritan, 367-70.

10. JMj to JMs, Mar. 9, 1781, Yale.

11. JMj to JMs, Jan. 18, 1782, Yale.

12. JMj to JMs, Jan. 6, 1782, Yale.

13. JMj to JMs, Mar. 15, 1781, Yale.

14. JMj to JMs, Feb. 20, 1781, Yale.

15. Ibid.

16. JMj to JMs, Apr. 11, 1784, Yale.

17. Ezra Stiles, The United States Elevated to Glory and Honor (New Haven, Conn., 1783), 2-3.

18. Scott, From Office to Profession, 60.

19. These letters are at Yale. They are bound together in a small book, "Letters VII," suggesting that there were other letters of this type that did not survive.

20. Letter addressed "Dear Ladies"; letter addressed "Dear P" (probably Polly).

21. JMj, “A Diary No. 4," Yale.

22. David E. Stannard, The Puritan Way of Death: A Study of Religion, Culture, and Social Change (New York, 1977).

23. JMj to JMs, Nov. 7, 1783, June 24, 1783, Yale.

24. JMj to JMs, June 24,1783 , Yale.

25. Ibid.

26. JMj to JMs, Apr. 11, 1784, Yale.

27. Henry May, The Enlightenment in America (New York, 1976), 185. For portraits of Edwards the Younger and Samuel Wales, see Robert L. Ferm, Jonathan Edwards the Younger, 1745-1801 (Grand Rapids, Mich., 1976) and Morgan, Gentle Puritan, 374-75.

28. The son introduces, timidly, his early attempts as textbook writer in JMj to JMs, Jan. 8, 1785, Yale.

29. JMj to JMs, Oct. 25, 1786, Yale.

30. JMj, "A Dialogue," Apr. 23, 1784, NYHS. All quotations are from this manu- 


\section{Notes to PAges 28-49}

156

script. The role of drama in New Haven after the Revolution is ambiguous. Stiles was clearly opposed, but Yale students were apparently much taken by drama. Kenneth Silverman, A Cultural History of the American Revolution (New York, 1987), 401-2.

31. Jedidiah Morse was, as we shall see in later chapters, prone to conspiracy theories. At times this tendency approached something like the condition moderns call paranoia. At least one scholar has suggested that a fear of effeminacy may be a cause ("inner source") of the tendency to believe and spread a conspiratorial world view. See Philip Greven, The Protestant Temperament: Patterns of Child-Rearing, Religious Experience, and the Self in Early America (New York, 1977), esp. 348-54.

32. New Haven Gazette, and the Connecticut Magazine, Oct. 5, 12, 1786. The debate took place Sept. 13, 1786.

33. The best description and analysis of New England clerical thought is Hatch, $\mathrm{Sa}$ cred Cause of Liberty, esp. chap. 3. Morse's demand for sumptuary laws revealed a profound concern that the new American Republic could quickly deteriorate into anarchy without strict control of behavior. Many other Americans shared this view. See especially McCoy, Elusive Republic, esp. chap. 3.

34. JMj to JMs, Mar. 29, 1785, Yale.

\section{A Place in the World: Settlement}

1. JMj to JMs, Nov. 29, 1786, and Dec. 1, 1786, Yale.

2. Ebenezier Hazárd to JMj, Feb. 14, 1788, NYHS; Samuel Beach to JMj, June 4, 1789, NYHS.

3. Richard Cary to Jeremy Belknap, Nov. 11, 1788, Collections of the Massachusetts Historical Society, Gth ser., vol. 4: 426-28.

4. Luigi Castiglioni, Viaggo: Travels in the United States of North America, 1785-1787 (Syracuse, 1983); Timothy Dwight, Travels in America, quoted in Henry H. Edes, "Charlestown in the Last Hundred Years," in The Memorial History of Boston, ed. Justin Windsor (Boston, 1883), vol. 3: 548.

5. Population statistics are drawn from town records reprinted in James $F$. Hunnewell, A Century of Town Life: A History of Charlestown Massachusetts, 17751887 (Boston, 1888), 187-88; Harry H. Edes, Charlestown Arcbives, 1629-1847 9, Oct. 5, 1789 (Selectmen's Meeting).

6. Sprague, Life of Jedidiab Morse, 12-15.

7. JMj to William Livingston, Oct. 26, 1787, quoted in Ralph H. Brown, "The American Geographies of Jedidiah Morse," Annals of the Association of American Geographers 31 (Sept. 1941): 157.

8. AG. The work was printed for Morse by Shepard and Kollock printers. A facsimile reprint of this work appeared in 1970 (Arno Press and New York Times Books).

9. JMj to JMs, Feb. 16, 1786, Yale; $A G, 146$.

10. The scholarship on the history of the book in America has exploded in the last decade. I have benefited from the essays in William L. Joyce et al., eds., Printing 
and Society in Early America (Worcester, Mass., 1983), esp. David D. Hall, "The Uses of Literacy in New England, 1600-1850," 1-47. Also crucial for understanding the impact of the print revolution is David Jaffee, "The Village Enlightenment in New England, 1760-1820," WMQ, July 1990, 327-46. The recommendations from Robert B. Thomas are quoted in Jaffee, 332. See also Gordon S. Wood, "The Democratization of Mind in the American Revolution," in The Moral Foundations of the American Republic, ed. Robert H. Horowitz, 102-28, 2d ed. (Charlottesville, Va., 1979) for an important discussion of the role of writing and authors in postrevolutionary America. Thomas Green to JMj, Jan. 21, 1792, NYHS; JMj to Christopher Ebeling, May 1794, Yale.

11. Thomas Green to JMj, Jan. 21, 1792, NYHS; JMj to Christopher Ebeling, May 1794, Yale.

12. Abiel Holmes to JMj, Apr. 5, 1789, Yale.

13. JMs to JMj, Oct. 20, 1792, Yale; JMj to JMs, Nov. 5, 1792, Yale; JMj to JMs, Jan. 30, 1790, Yale; JMj to JMs, July 12, 1792, Yale.

14. For an excellent account of the changes in the New England ministry, see Scott, From Office to Profession, 1-76.

15. JMj to JMs, May 9, 1785, Yale.

16. Bushman, From Puritan to Yankee, 286-88.

17. JMj to JMs, Jan. 7, 1789, Yale.

\section{A Period of Singular Revolutions}

1. JMj to Dear Friend and Brother, Mar. 1823, Yale.

2. JMj, A Sermon Preached Lord's Day, February 28, 1790, Upon the Death of Richard Cary, Esq. of Charlestown . . (Boston, 1790), 8-9.

3. May, Enlightenment in America, 358.

4. This view of America in the late 1780 s and 1790 s is based on a wide range of sources; the most basic are: Rowland Berthoff, "Independence and Attachment, Virtue and Interest: From Republican Citizen to Free Enterpriser, 1787-1837," in Uprooted Americans: Essays to Honor Oscar Handlin, ed. Richard L. Bushman, Neil Harris, David Rothman, Barbara M. Solomon, and Stephan Thernstrom (Boston, 1979); Shalhope, "Republicanism and Early American History"; McCoy, Elusive Republic; and Appleby, Capitalism and the New Social Order.

5. For the history of Unitarianism, see Conrad Wright, The Beginnings of Unitarianism (Boston, 1955), and for a broader account of the growth of religious liberalism, see May, Enlightenment in America and Ahlstrom, Religious History of the American People, esp. 388-402.

6. Sprague, Life of Jedidiab Morse, 50-54; JMj to JMs, Dec. 10, 1789, Yale.

7. William Bentley, The Diary of William Bentley, D.D. (Gloucester, Mass., 1962), 1:187; William Bentley, Sermon at Stone Chapel (Boston, 1790), 9, 21.

8. Ashabel Green to JMj, June 17, 1792, NYPL; Morse, Jedidiab Morse: A Champion, 35-36; Henry Channing to JMj, Feb. 27, 1792, Apr. 13, 1792, June 3, 1796, Yale. 
9. JMj to Matthew Carey, May 8, 1794; Matthew Carey to JMj, May 14, 1794; Matthew Carey to JMj, June 5, 1794, HSP.

10. Thomas and Andrews to Matthew Carey, Mar. 8, 1795, Feb. 16, 1796, HSP.

11. Isaiah Thomas to JMj, Feb. 17, 1792; E. T. Andrews to Isaiah Thomas, May 1, 1793; June 11, 1793, AAS.

12. St. George Tucker, A Letter to the Reverend Jedidiab Morse, A.M., Author of the American Universal Geography, by a Citizen of Williamsburg (Richmond, Va., 1795). The pamphlet is reprinted in William and Mary College Quarterly Historical Magazine, 2d ser., 20 (1940): 487-91. Brown, “American Geographies of Jedidiah Morse," 181-84.

13. Banner, Toward the Hartford Convention. This provides an excellent account of the Federalist mind in Massachusetts.

14. JMj to JMs, July 1788. Many, but not all, Americans shared Morse's desire for a national government that could govern without opposition, see Richard Hofstadter, The Idea of a Party System (Berkeley and Los Angeles, 1969), esp. chaps. 1-2.

15. JMj, Elements of Geography (Boston, 1795), 121.

16. JMj, "Thanksgiving Sermon," Nov. 26, 1789, MS, Yale.

17. JMj, The Present Situation of Other Nations of the World, Contrasted with our Own. A Sermon Delivered at Charlestown ... February 19, 1795, 6-7, 10, 12, 14, 30-31, 34-35, Yale.

18. JMs to JMj, Aug. 2, 1795, Yale.

19. JMj to JMs, Aug. 12, 1795; see also JMj to JMs, June 10, 1795, Yale.

20. Sprague, Life of Jedidiah Morse, 230-31; Oliver Wolcott to JMj, June 22, 1794, NYPL.

21. Oliver Wolcott to JMj, Sept. 20, 1795, NYPL.

22. Vernon Stauffer, New England and the Bavarian Illuminati (New York, 1918) is the standard account.

23. Letters to Wolcott and Pickering quoted in Stauffer, Bavarian Illuminati, 240-41.

24. John C. Fitzpatrick, ed., The Writings of George Washington, 39 vols. (Washington, D.C., 1931-44). George Washington to JMj, Feb. 28, 1799, in Fitzpatrick, Writings of George Washington 37:140; John Jay to JMj, Sept. 4, 1798, NYPL.

25. See JMj, An Address to the Students at Phillips Academy in Andover . . July 9, 1799 (Charlestown, 1799).

26. Hunnewell, Century of Town Life, reprinted extracts of the town and church records, 24, 187-88.

27. JMj, "Untitled Sermon Ms.," Jan. 6, 1799, Yale; Population statistics from W. S. Rossiter, A Century of Population Growth in the United States, 1790-1900 (Washington, D.C., 1909) and Abstract of the Census of Massachusetts, from the Eighth U.S. Census (Boston, 1863), 205-8, 227-33.

28. Independent Chronicle (Boston), Jan. 7, 1799, and June 18, 1798; Stauffer, Bavarian Illuminati, 272.

29. JMj, A Sermon, Delivered at the New North Church in Boston . . and in the Afternoon 
at Charlestown, May 9, 1798, Being the Day Recommended by Jobn Adams . . for Solemn Humiliation, Fasting and Prayer (Boston, 1798), 19.

30. JMj, A Sermon Preached at Charlestown, on November 29, 1798, in the Anniversary of Thanksgiving in Massachusetts. With Appendix, 2d ed. (Boston, 1799), 12.

31. JMj to EM, May 18, 1799; Thomas Martin to JMj, June 29, 1794; Israel Evans to JMj, Nov. 17, 1797, Yale; Deed Record, vol. 1, 176-78, Kennebec Country Court House, Augusta, Maine; Registry of Deeds, vol. 129: 137, vol. 125: 45960; Middlesex County Court House, Cambridge, Massachusetts.

32. JMj, A Sermon, Delivered at the New North Church, 20. In making a golden perfect past a crucial element in his jeremiads, Morse was acting in a long and distinguished New England tradition. Theodore Dwight Bozeman has claimed that New England clerics in the 1660s began to include in their jeremiads "an idealized picture of an earlier New England passionately devoted to the Congregational cause" (311) and that the sermons that evolved "pointed the way, not toward a dynamic, changing society, but to the repose of static perfection" (343). Bozeman, To Live Ancient Lives.

33. JMj, A Sermon, Delivered at the New North Church, 21.

34. JMj to JMs, July 18,1795 , Yale.

35. JMj, A Sermon Exbibiting the Present Dangers, and Consequent Duties of the Citizens of the United States of America. Delivered at Charlestown, April 25, 1799. The Day of the National Fast (Boston, 1799), 31.

36. Ibid., 28-29.

37. Ibid., 29.

38. JMj, A Sermon, Delivered at the New North Church, 11-12.

39. Ibid., 27.

40. Timothy Dwight, The Duty of Americans in the Present Crisis ... (New Haven, Conn., 1798).

41. Massachusetts Mercury, Aug. 21, 1798. In dealing with the aftermath of Morse's Illuminati sermon, I have relied heavily on the excellent account in Phillips, Jedidiab Morse, 85-89.

42. Christoph Ebeling to William Bentley, Mar. 13, 1799, in American Antiquarian Society Proceedings 35 (1925): 307-33; Christoph Ebeling to JMj, Mar. 20, 1799, Yale.

43. Morse's account of his problems is in JMj to JMs, Nov. 30, 1799, Yale.

44. JMj to Ezekiel Williams, Oct. 16, 1799; JMj to Walter King, Aug. 28, 1799, Yale.

45. JMj to Oliver Wolcott, Jr., June 5, 1799, CHS.

46. JMj to Oliver Wolcott, July 28, 1798, CHS; JMj to EM, May 28, 1799, Yale.

47. JMj to Dr. Nisbet, Apr. 4, 1800, Yale.

\section{The Two-Layered Life}

1. JMj to Oliver Wolcott, Jr., June 11, 1799; JMj to Oliver Wolcott, Jr., Oct. 27, 1800, CHS. 
2. JMj to John Adams, May 23, 1800, Yale.

3. Robert Edson Lee, "Timothy Dwight and the Boston Palladium," New England Quarterly 35 (1962): 229-46; JMj to Oliver Wolcott, Jr., Dec. 10, 1800, CHS. Morse also expressed his concern over splits among the Federalists in JMj to Oliver Wolcott, Jr., Oct. 27, 1800, CHS and JMj to John Jay, May 23, 1800, Yale.

4. Independent Chronicle (Boston), Apr. 27, 1801.

5. JMj to JMs, Dec. 22, 1800, Yale.

6. JMj to Dr. Nisbet, Apr. 4, 1800, Yale.

7. JMj to William Plummer, Nov. 16, 1803, Dec. 12, 1803, NHHS.

8. The election of Ware and related issues have received considerable scholarly attention. See Conrad Wright, "The Election of Henry Ware: Two Contemporary Accounts," Harvard Library Bulletin 17 (July 1969): 245-78 and The Beginnings of Unitarianism in America (Boston, 1955); Earl Morse Wilbur, A History of Unitarianism in Transylvania, England and America (Cambridge, Mass., 1952) and Samuel Eliot Morison, Three Centuries of Harvard (Cambridge, Mass., 1936).

9. Morse, Jedidiah Morse: A Champion, 83-85. Wright, "Election of Henry Ware," 245-78; JMj to Joseph Lyman, Dec. 27, 1804, Yale.

10. JMj, The True Reasons. . . (Charlestown, 1805), 17-18, 28.

11. JMj, An Appeal to the Public ... (Charlestown, 1814), x.

12. JMj to Joseph Lyman, June 15, 1805, Yale.

13. Panoplist 1 (June 1806): i.

14. Ibid., ii.

15. Ibid., iii.

16. JMj to Dr. Kemp, Oct. 17, 1804, Yale.

17. Abiel Holmes to JMj, Dec. 18, 1807, NYHS.

18. Panoplist 1, no. 3 (1806): 197.

19. Ibid., no. 6 (1806): 262-63. For detailed discussion of this transformation, see Scott, From Office to Profession, esp. chaps. 2-3.

20. Leonard Woods to JMj, Mar. 15, 1806, Yale.

21. JMj to Joseph Lathrop, Nov. 18, 1807, Yale.

22. Morse, Jedidiab Morse: A Champion, 101-14.

23. For the founding of Andover, see Leonard Woods, History of Andover Theological Seminary (Boston, 1885); Edward A. Park, The Associate Creed of Andover Theological Seminary (Boston, 1883) and John H. Giltner, "The Fragmentation of New England Congregationalism and the Founding of Andover Seminary," Journal of Religious Thought 20 (1963-64): 27-42. For an introduction to the notion of Puritan tribalism, see Edmund Morgan, The Puritan Family (New York, 1966), 168-86.

24. Panoplist 3 (Sept. 1808): 410.

25. JMj, "Journal of a Mission to the Isle of Shoals," MS at Yale.

26. Phillips, Jedidiah Morse is excellent on Morse as missionary and organizer, especially chapter 4.

27. Charitable Society for the Education of Indigent Young Men for the Ministry of the Gospel, An Address. . . (n.p., 1814), 8. 


\section{Notes to Pages 94-104}

28. Ibid., 19-20.

29. Phillips, Jedidiah Morse, 187-88; Sprague, Life of Jedidiab Morse, 143-44.

30. JMj, A Discourse, delivered at the African Meeting-House ... (Boston, 1808), 5.

31. Ibid., 6 .

32. Ibid., 17-18.

33. JMj, A Discourse Delivered at the Organization of the Association (Boston: 1813), 321 . The debate over the nature of benevolent reform in the first quarter of the nineteenth century has centered on the motivations of the reformers. For the view that the reformers were attempting to reestablish their social control and personal authority, see Clifford S. Griffin, Their Brother's Keepers: Moral Stewardship in the United States, 1800-1865 (New Brunswick, N.J., 1960); W. David Lewis, "The Reformer as Conservative: Protestant Counter-Subversion in the Early Republic," in The Development of an American Culture, ed. Stanley Coben and Lorman Ratner (Englewood Cliffs, N.J., 1970) and Donald G. Matthews, "The Second Great Awakening as an Organizing Process, 1780-1830: An Hypothesis," American Quarterly 21 (Spring 1969): 23-44. For a critique of the "social control" thesis, see Lois W. Banner, "Religious Benevolence as Social Control: A Critique of an Interpretation," Journal of American History 60 (June 1973): 23-41. For a somewhat different view of the issue, see Nathan O. Hatch, The Democratization of American Christianity (New Haven, Conn., 1989), 220-26.

34. JMs to JMj, Dec. 9, 1800, Yale.

35. JMj to Church members, Nov. 12, 1802, Yale.

36. JMj to JMs, May 5, 1803, Yale.

37. A copy of the Act of Incorporation is in the existing Parish Records, Congregational Society Library, Boston.

38. JMj to JMs, Feb. 22, 1803, Yale.

39. Ibid.

40. JMj to JMs, May 5, 1803, Yale.

41. Ibid., JMj to Parish Committee of the Congregational Church, Jan. 4, 1804, and JMj to First Parish in Charlestown, Jan. 20, 1804, Yale.

42. JMj to Parish Committee, Jan. 4, 1804, Yale.

43. William Goodwin to JMj, Jan. 27, 1804, Lincoln County Court House, Old Jail, Wiscasset, Maine (hereaf ter cited as Lincoln County Court House).

44. JMj to William Goodwin, Jan. 28, 1804, Linçoln County Court House.

45. JMs to JMj, Oct. 4, 1809, Yale.

46. A copy of the petition is in the Parish Records at the Congregational Society Library, Boston.

47. Isaac Warren to JMj, Apr. 1814, Yale.

48. Morse, Jedidiab Morse: A Champion, 153-55; Henry Edes, History of the Harvard Church in Charlestown, Massachusetts, 1815-1879 (Boston, 1879), 80-85.

49. Sprague, Life of Jedidiab Morse, 150-55.

50. Hannah Adams, A Narrative (Boston, 1814), 2. 
51. JMj, Appeal to the Public.

52. Adams, $A$ Narrative, 8-9. Lowell's and Higginson's remarks are printed in Adams, A Narrative (sep. pages) 1, 4 (Lowell), 1-3 (Higginson); David Osgood to JMj, July 8, 1814, NYPL.

53. JMj, Appeal to the Public, v; Sereno Dwight to JMj, June 28, 1814, NYPL; Ward Saff ord to JMj, July 4, 1814, NYPL. For a detailed discussion of the Codman Affair, see Conrad Wright, "Institutional Reconstruction in Unitarian Controversy," in American Unitarianism, 1805-1865, ed. Conrad Elrich Wright (Boston, 1989).

54. Quoted in Morse, Jedidiah Morse: A Champion, 137-38.

55. Joseph Lathrop to JMj, Mar. 27, 1815, NYPL; JMj, American Unitarianism (Boston, 1815).

56. See particularly the preface to JMj, Appeal to the Public, i-iix.

57. JMj to Elizabeth Goodwin, Nov. 30, 1807, Lincoln County Courthouse.

58. Will of Jedidiah Morse, Sr., Pomf ret County Courthouse, Pomf ret, Connecticut. Will is dated Dec. 16, 1807, the codicil, Nov. 15, 1815.

59. Parish Records, Congregational Society Library, Boston; JMj to Oliver Wolcott, Apr. 4, 1800, CHS.

60. All references to land transactions by Morse, Putnam, and others are to book and page numbers in Registry of Deeds, Middlesex County Court House, Cambridge, Massachusetts. Book 129, p. 137; Book 129, p. 137 (the discharge of mortgage); Book 170, p. 507; Book 170, p. 508; Book 170, p. 509; Unsigned memorandum, Hannah Adams Papers, Massachusetts Historical Society; Roger D. Joslyn, Vital Records of Charlestown, Massachusetts to the Year 1850 (Boston, 1984). See also Conrad Wright, "The Controversial Career of Jedidiah Morse," Harvard Library Bulletin 31, no. 1, p. 79.

61. Book 168, pp. 8-10; Book 168, p. 468; Book 177, p. 5, 7; Book 229, p. 410.

62. Margin note, Book 170, p. 508; Book 167, pp. 341-43, 371-74; Aaron Putnam to $\mathrm{JMj}$, Sept. 10, 1809, Yale.

63. Book 200, p. 439; Book 200, p. 251; Book 225, p. 251.

64. Morse, Jedidiab Morse: A Champion, 103-4.

65. JMj to SFBM, Nov. 13, 1813, LC.

66. EM to SFBM, Aug. 3, 1814, LC; Samuel Whiting to JMj, Oct. 10, 1814, Mar. 22, 1815, NYPL; John Folsom to JMj, Dec. 18, 1813, NYPL; JMj to SFBM, Nov. 23, 1814, LC: Robert Ralston to JMj, Jan. 23, 1815, NYPL and Sereno Dwight to JMj, July 21, 1814, NYPL.

67. Elijah Parish to JMj, Dec. 20, 1814, NYPL; Sereno Dwight to JMj, July 6, 1814, NYPL; JMj to Benjamin Trumbull, July 15, 1814, NYHS.

68. Josiah Bartlett to JMj, Feb. 18, 1817, NYPL.

69. Sprague, Life of Jedidiah Morse, 40-41, JMj to Joseph Lyman, Mar. 4, 1817, Yale.

70. JMj to Children, Feb. 13, 1819, LC.

71. The indenture was drafted and signed Nov. 7, 1804, but not entered at the Registry of Deeds until Sept. 6, 1816, Book 215, pp. 379-83. 
72. EM to SFBM, Apr. 1819, LC.

73. JMj to SFBM, May 13, 1819, LC.

74. SFBM to Mr. Cornelius, June 17, 1819, LC.

75. JMj to Sons, July 27, 1819, LC.

76. SFBM to JMj, Oct. 26, 1819, LC.

77. JMj to EM, Jan. 15, 1819, NYPL.

78. JMj to Leonard Woods, Mar. 15, 1820, LC; Leonard Woods, Love of Popularity, A Sermon, Delivered, Feb. 23, 1820 . . (Charlestown, 1820).

\section{Family}

1. JMj, The American Universal Geography (Boston, 1793), vol. 1: 311-14.

2. Jonathan Morse to JMj, June 14, 1805, Yale.

3. JMs to JMj, Jan. 5, 1805; JMj to JMs, Jan. 1, 1801, and JMs to JMj, Jan. 9, 1795, Yale.

4. JMj to JMs, July 30, 1792, Yale. On April 20, 1820, Jonathan Morse mortgaged a part of his land to John Davis for fifteen hundred dollars; this mortgage was never removed. On March 23, 1824, Jonathan sold what appears to be his remaining land to William Bowen for forty-five hundred dollars. Jedidiah Morse witnessed this last transaction. Deed Records, Woodstock Town Office, Woodstock, Connecticut.

5. JMs to JMj, Dec. 11, 1791, Yale.

6. Bowen, History of Woodstock 7:490-97.

7. The common male names in the Morse family prior to Jedidiah, Sr., were John, Peter, and Anthony. Deacon Morse's wife, Sarah Child, may have been honored by the naming of Jedidiah, Jr.'s last child (1808), Sarah Rebecca. For the record, Sarah Child was the daughter of John and Abigail Child.

8. Bowen, History of Woodstock 7:490-97; JMj to JMs, Feb. 10, 1794, May 5, 1803; JM to Walter King, Aug. 16, 1799, Yale.

9. Hannah Moor to JMj, July 6, 1792, Yale; Hunnewell, Century of Town-Life, 193.

10. EM to SFBM, Nov. 9, 1814, LC.

11. For child-rearing trends during the late eighteenth and early nineteenth centuries, see Greven, Protestant Temperament, esp. pt. 3, "The Moderates: The Self Controlled" and Joseph F. Kett, Rites of Passage: Adolescence in America 1790 to the Present (New York, 1977).

12. SFBM relates the story of Madame Rand in an odd untitled MS, dated May 13, 1856, NYPL.

13. JMj to SFBM, Dec. 11, 1799, Dec. 5, 1799, Nov. 27, 1799; EM to Sons, Oct. 22, 1802, Yale.

14. JMj, Address to the Students at Phillips Academy, 8-9; EM to SFBM, July 30, 1813, LC.

15. JMs to Grandsons, May 22, 1805, Yale.

16. JMj to SFBM, Mar. 7, 1801; Jonathan French to JMj, Apr. 7, 1799, Boston Public Library. 
17. Edward Lind Morse, ed., Samuel F. B. Morse: His Letters and Journals (Boston, 1914), vol. 1: 9-10.

18. EM to SFBM, Dec. 27, 1805, Nov. 23, 1805, Nov. [?], 1805, LC.

19. SFBM to Parents, May 13, 1807; Mar. 6, 1808, LC.

20. EM to SFBM, June 28, 1805; JMj and EM to SFBM, July 30, 1805, LC.

21. JMj and EM to SFBM, Dec. 27, 1805; SFBM, "Manuscript Essay," June 13, 1808, LC.

22. SFBM to Parents, Jan. 1, 1809, LC.

23. SFBM to JMj, Sept. 5, 1807, LC.

24. Sennett, Uses of Disorder, chap. 1. Philip Greven, writing about conflicted characters such as Jedidiah and Samuel F. B. Morse, states, "The wars of the self against the self became transformed into attacks of others upon self-and external enemies and dangers were easier to conf ront than inner enemies." Greven, Protestant Temperament, 353.

25. SFBM to Parents, July 22, 1810; JM to SFBM, July 26, 1810, LC.

26. SFBM to "Mama," Sept. 8, 1810, LC.

27. For examples of the reports on Finely, see $\mathrm{H}$. Bromfield to JMj, June 23, 1814, Aug. 12, 1812, and Rev. John Romeyn to JMj, Dec. 10, 1814, NYPL.

28. SFBM to Parents, Apr. 23, 1815, LC.

29. See SFBM, Foreign Conspiracy Against the Liberties of the United States (New York, 1835) and Imminent Dangers to the Free Institutions of the United States . . (New York, 1835).

30. Morse, Samuel F. B. Morse 2:296-98.

\section{The End}

1. EM, "List of Articles ..." May-June 1820, LC.

2. JMj to EM, May 31, 1820; JMj to Misses S. M. and K. Bradstreet, Apr. 20, 1820, LC.

3. William Greenough to JMj, June 28,1826 , Gratz Collection, HSP.

4. JMj to SFBM, June $14,1821, \mathrm{LC}$.

5. List entitled "Books Sold at Auction in New Haven," Aug. 5, 1823; JM to SFBM, Jan. 14, 1821, LC.

6. JMj to W. W. Woodward, Jan. 9, 1823, Gratz Collection, HSP; JMj to SFBM, Jan. 14, 1821, LC.

7. Richard Morse to Sidney Morse, Feb. 4, 1825, Yale.

8. SFBM to Patent Office, Aug. 6, 1823; JMj to SFBM, Aug. 30, 1823, LC.

9. Phillips, Jedidiab Morse, chap. 12.

10. The history of Indian-white relations, and especially the history of white attitudes toward Indians, can be found in Bernard W. Sheehan, Seeds of Extinction: Jeffersonian Philanthropy and the American Indian (Chapel Hill, N.C., 1973); Richard Drinnon, Facing West: The Metaphysics of Indian Hating and Empire Building 
(Minneapolis, 1980) and Richard Slotkin, The Fatal Environment: The Myth of the Frontier in the Age of Industrialization, 1800-1890 (New York, 1985).

11. $\mathrm{JMj}, A$ Report to the Secretary of $W$ ar of the United States, On Indian Affairs, Comprising a Narrative of a Tour . . 40-41, 65-96.

12. Ibid., 74-75, 81 .

13. Ibid., 86 .

14. Ibid., 73-78.

15. Ibid., 79-80.

16. Ibid., 85 .

17. NA, North American Review 16 (1823): 39-40. For this view of Morse, I a m indebted to Sheehan, Seeds of Extinction, 276-79.

18. Sidney Morse to JMj, Apr. 24, 1824, LC.

19. Morse's proposal for the Society and his general outline of its structure is in his Report to the Secretary of War, 75-78; see Phillips, Jedidiab Morse.

20. JMj to Sidney Morse, Jan. 14, 1820, LC; JMj to SFBM, Mar. 18, Mar. 23, 1821, LC.

21. JMj to SFBM. Feb. 8, 1825, LC.

22. EM to Sidney, Jan. 16, 1826; Sidney's testimony is in a letter to William B. Sprague contained in Sprague's Life of Jedidiab Morse, 283.

23. Probate Records, vol. 36: 474, County Court House, New Haven, Connecticut (hereafter cited as Probate Records [New Haven]).

24. Probate Records (New Haven), vol. 37: 527, July 25, 1827.

25. EM to Richard Morse, July 7, 1827, LC.

\section{Epilogue}

1. For excellent discussions of Samuel F. B. Morse's art, see William Kloss, Samuel F. B. Morse (New York, 1988) and, especially, Paul J. Staiti, Samuel F. B. Morse (Cambridge, 1989).

2. On seeing the watercolor, Samuel remarked, "I remember giving it to Nancy Shepard and it seems that Nancy just previous to her death gave it to Mrs. Hovey. My Father's likeness, but especially my Mother's, were good likenesses still. Richard's was also tolerable, but Sidney's and my own did not strike me agreeably. My Father's figure without legs, the picture having been abruptly left before completing it." Samuel F. B. Morse, "Manuscript Account of Morse's visit to Charlestown, after 18 year absence," May 13, 1856, Jedidiah Morse Papers, NYPL. 


\section{Bibliography}

\section{Essay on Sources}

I have most fully paid my intellectual debts in the notes to this volume. In this essay I should like to mention the sources that have most centrally influenced my interpretation of Jedidiah Morse.

Because I focused on Morse's interior life, his private papers were crucial. By far the largest collection of papers is the Morse Family Papers at the Yale University Library. The Samuel F. B. Morse Papers at the Library of the Congress contain important documents about family matters during the first twenty-five years of the nineteenth century. The New York Public Library also has a significant collection of Morse Family Papers. Jedidiah Morse was a tireless correspondent, and his letters have ended up in a number of places. Much of his business correspondence has been lost. Morse's sermons and pamphlets are almost as important as his correspondence. Few of his sermons in manuscript remain; the ones that do are, as far as I know, in the Morse Family Papers at Yale.

A number of works have helped me put Morse into a general context. For an understanding of Woodstock and late colonial agrarian culture, I have used James A. Henretta, The Evolution of American Society, 17001815: An Interdisciplinary Analysis (Lexington, Mass., 1973) and "Families and Farms: Mentalite in Pre-Industrial America," William and Mary Quarterly, 3d ser., 35 (Jan. 1978): 3-32. J. E. Crowley, This Sheba Self: The Conceptualization of Economic Life in Eighteenth-Century America (Baltimore, 1974) was also helpful. Richard L. Bushman's From Puritan to Yankee: Character and Social Order in Connecticut, 1690-1765 (Cambridge, Mass., 1967) deeply influenced my view of Morse's childhood.

For the Revolution era, I am one of the many historians indebted to Bernard Bailyn, The Ideological Origins of the American Revolution (Cambridge, Mass., 1967) and Gordon Wood, The Creation of the American Republic, 1776-1787 (Chapel Hill, 1969). Also important were Joyce Appleby, Capitalism and the New Social Order: The Republican Vision of the 1790s (New York, 1984) and Joseph J. Ellis, After the Revolution: Profiles of American Culture (New York, 1979).

Jedidiah Morse was not a systematic political thinker. His life and thought were shaped to a great extent by general cultural currents between the Revolution and 1820. In understanding these currents, I am 
especially indebted to Henry F. May, The Enlightenment in America (New York, 1976); James M. Banner, Jr., Toward the Hartford Convention: The Federalists and Origins of Party Politics in Massachusetts, 1789-1815 (New York, 1970); Linda Kerber, Federalists in Dissent: Imagery and Ideology in Jeffersonian America (Ithaca, N.Y., 1970); and Rowland Berthoff, "Independence and Attachment, Virtue and Interest: From Republican Citizen to Free Enterpriser, 1787-1837," in Uprooted Americans: Essays to Honor Oscar Handlin, ed. Richard Bushman, Neil Harris, David Rothman, Barbara M. Solomon, and Stephan Thernstrom, 97-124 (Boston, 1979). More important than these works, however, has been Steven Watts, The Republic Reborn: War and the Making of Liberal America, 1790-1820 (Baltimore, 1987). Watts has influenced my concepts of liberalism and republicanism as well as my ideas about biography and the use of psychological theory.

My understanding of American religious life after the Revolution has been shaped by May, Enlightenment in America; Sydney E. Ahlstrom, A Religious History of the American People (New Haven, Conn., 1972); and Nathan O. Hatch, The Sacred Cause of Liberty: Republican Thought and the Millennium in Revolutionary New England (New Haven, Conn., 1977). In pondering the Second Great Awakening and Morse's role in it, I have no doubt been influenced by the works that argue that established clerics were attempting to reestablish their authority in a chaotic culture. For example, see Clifford S. Griffin, Their Brother's Keepers: Moral Stewardship in the United States, 18001865 (New Brunswick, N.J., 1960) and Donald G. Matthews, "The Second Great Awakening as an Organizing Process, 1780-1830," American Quarterly 21 (Spring 1969): 23-44. In the end, however, I agree with Nathan O. Hatch's remark that the religious history of the early national period remains "elusive and uncharted." Even much-studied figures and churches need to be reappraised in the light of the general reassessment of the early national period. See especially "Redefining the Second Great Awakening: A Note on the Study of Christianity in the Early Republic," in The Democratization of American Christianity, by Nathan O. Hatch (New Haven, Conn., 1989).

Any attempt to construct a psychological interpretation of a figure like Morse is built on complex foundations. As the notes make clear, I am especially indebted to the works of Erik Erickson. His essay "Wholeness and Totality," in Studies from Psychology, Sociology, Antbropology, ed. Leon Bramson and George Goethals, 119-31 (New York, 1968) was particularly important in coming to understand Morse. Two historians also were important. I was influenced by Michael Zuckerman's essay "The Fabrication of Identity in Early America," William and Mary Quarterly 34, 3d ser. (1977): 192-201 and Watts, The Republic Reborn. Both works use psychological theory in a stimulating and convincing way. Whatever insights I gained from the 


\section{The Life of Jedidiah MoRse}

168

works above have to share the stage with my own subjective response to Morse. Historians who attempt to construct theoretically informed psychological generalizations should admit that their creations have important roots in their own experience.

\section{Secondary Works}

\section{Books}

Ahlstrom, Sidney E. A Religious History of the American People. New Haven, Conn.: Yale Univ. Press, 1972.

- A Religious History of the American People. New Haven, Conn.: Yale Univ. Press, 1972.

Appleby, Joyce. Capitalism and the New Social Order: The Republican Vision of the 1790s.

New York: New York Univ. Press, 1984.

Banner, James. Toward the Hartford Convention: Federalists and the Origins of Party Politics in Massachusetts, 1789-1815. New York: Knopf, 1970.

Bercovitch, Sacvan. The American Jeremiad. Madison: Univ. of W isconsin Press, 1978.

Berk, Stephen E. Calvinism versus Democracy: Timothy Dwight and the Origins of American Evangelical Orthodoxy. Hamden, Conn.: Anchor Books, 1974.

Bowen, Clarence. The History of Woodstock Connecticut . . Genealogies of Woodstock Families.

7 vols. Norwood, Mass.: Plimpton Press, 1926.

Bozeman, Theodore Dwight. To Live Ancient Lives: The Primitivist Dimension in Puritanism. Chapel Hill: Univ. of North Carolina Press, 1988.

Bramson, Leon, and George W. Goethals, eds. War: Studies from Psychology, Sociology, Anthropology. New York: Basic Books, 1968.

Buell, Lawrence. New England Literary Culture: From Revolution to Renaissance. Cambridge: Cambridge Univ. Press, 1986.

Bushman, Richard L. From Puritan to Yankee: Character and Social Order in Connecticut, 1690-1765. Cambridge: Harvard Univ. Press, 1967.

Castiglioni, Luigi. Viaggo: Travels in the United States of North America, 1785-1787. Syracuse: Syracuse Univ. Press, 1983.

Daniels, Bruce C. Fragmentation of New England: Comparative Perspective on Economic, Political and Social Divisions in the Eighteenth Century. Westport, Conn.: Greenwood Press, 1988.

Douglas, Ann. The Feminization of American Culture. New York: Knopf, 1977.

Drinnon, Richard. Facing West: The Metaphysics of Indian Hating and Empire Building. Minneapolis: Univ. of Minnesota Press, 1980.

Edes, Harry H. Charlestown Archives, 1629-1847. Vol. 9. Oct. 5, 1789 (Selectmen's Meeting). Boston Public Library.

Edes, Henry. History of the Harvard Church in Charlestown, Massacbusetts, 1815-1879. Boston: privately printed, 1879. 


\section{BIBLIOGRAPHY}

Erikson, Erik. Childhood and Society. 2d ed. New York: W. W. Norton, 1963

Identity: Youth and Crisis. New York: W. W. Norton, 1963.

Ferm, Robert L. Jonathan Edwards the Younger, 1745-1801. Grand Rapids, Mich.: Eerdmans, 1976.

Foster, Frank H. A Genetic History of the New England Theology. 1907. Reprint. New York: Russell and Russell, 1963.

Goen, C. C. Revivalism and Separatism in New England, 1740-1800. New Haven, Conn.: Yale Univ. Press, 1962.

Greven, Philip. The Protestant Temperament: Patterns of Child-Rearing, Religious Experience, and the Self in Early America. New York: Knopf, 1977.

Griffin, Cilfford S. Their Brother's Keepers: Moral Stewardship in the United States, 18001865. New Brunswick, N.J.: Rutgers Univ. Press, 1960.

Gross, Robert A. The Minutemen and Their World. New York: Hill and Wang, 1976.

Grosvenor, L. History of the First Congregational Church and Society of Woodstock, Connecticut. Worcester, Mass.: privately printed, 1860.

Hahn, Steven, and Jonathan Prude, eds. The Countryside in the Age of Capitalist Transformation: Essays in the Social History of Rural America. Chapel Hill: Univ. of North Carolina Press, 1985.

Harris, Neil. The Artist in American Society: The Formative Years, 1790-1860. New York: Braziller, 1966.

Hatch, Nathan O. The Democratization of American Christianity. New Haven, Conn.: Yale Univ. Press, 1989.

. The Sacred Cause of Liberty: Republican Thought and the Millennium in Revolutionary New England. New Haven, Conn.: Yale Univ. Press, 1977.

Hofstadter, Richard. Paranoid Style in American Politics. New York: Knopf, 1965. . The I dea of a Party System. Berkeley and Los Angeles: Univ. of California Press, 1969.

Hunnewell, James F. A Century of Town Life: A History of Charlestown Massachusetts, 17751887. Boston: Little, Brown, 1888.

Joslyn, Roger D. Vital Records of Charlestown, Massachusetts to the Year 1850. Boston: New England Historic Genealogical Society, 1984.

Joyce, William L., David D. Hall, Richard D. Brown, and John Hench. eds., Printing and Society in Early America. Worcester, Mass.: American Antiquarian Society, 1983.

Keller, Charles Roy. The Second Great Awakening in Connecticut. New Haven, Conn.: Yale Univ. Press, 1942.

Kelley, Brooks Mather. Yale: A History. New Haven, Conn.: Yale Univ. Press, 1974.

Kett, Joseph F. Rites of Passage: Adolescence in America 1790 to the Present. New York: Basic Books, 1977.

Kloss, William. Samuel F. B. Morse. New York: H. N. Abrams, 1988.

Larned, Ellen D. History of Windham County, Connecticut. 2 vols. Worcester, Mass.: privately printed, 1874.

May, Henry. The Enlightenment in America. New York: Oxford Univ. Press, 1976. 
McCoy, Drew R. The Elusive Republic: Political Economy in Jeffersonian America. Chapel Hill: Univ. of North Carolina Press, 1980.

Miller, Perry. "Errand into the Wilderness." In Errand into the Wilderness, by Perry Miller. Cambridge: Harvard Univ. Press, 1956.

- The New England Mind: From Colony to Province. Cambridge: Harvard Univ. Press, 1952.

Morgan, Edmund S. The Gentle Puritan: A Life of Ezra Stiles, 1727-1795. Chapel Hill: Univ. of North Carolina Press, 1962.

- The Puritan Family. New York: Harper and Row, 1966.

Morison, Samuel Eliot. Three Centuries of Harvard. Cambridge: Harvard Univ. Press, 1936.

Morse, Edward Lind, ed. Samuel F. B. Morse: His Letters and Journals. Boston: Houghton Mifflin, 1914.

Morse, James K. Jedidiab Morse: A Champion of New England Orthodoxy. New York: AMS Press, 1939.

Park, Edward A. The Associate Creed of Andover Theological Seminary. Boston: privately printed, 1883.

Perry, Lewis. Intellectual Life in America: A History. Chicago: F. Watts, 1984.

Phillips, Joseph W. Jedidiab Morse and New England Congregationalism. New Brunswick, N.J.: Rutgers Univ. Press, 1983.

Rossiter, W. S. A Century of Population Growth in the United States, 1790-1900. Washington, D.C.: Bureau of the Census, 1909.

Royster, Charles. A Revolutionary People at War. Chapel Hill: Univ. of North Carolina Press, 1979.

Scott, Donald M. From Office to Profession: The New England Ministry, 1750-1850. Philadelphia: Univ. of Penn. Press, 1978.

Sellers, Charles. The Market Revolution. New York: Oxford Univ. Press, 1991.

Sennett, Richard. The Uses of Disorder: Personal Identity and City Life. New York: Vintage Books, 1970.

Sheehan, Bernard W. Seeds of Extinction: Jeffersonian Philanthropy and the American Indian. Chapel Hill: Univ. of North Carolina Press, 1973.

Silverman, Kenneth. A Cultural History of the American Revolution. New York: Columbia Univ. Press, 1987.

Slotkin, Richard. The Fatal Environment: The Myth of the Frontier in the Age of Industrialization, 1800-1890. New York: Atheneum, 1985.

Smith, James Ward, and A. Leland Jamison, eds. The Shaping of American Religion.

Princeton, N.J.: Princeton Univ. Press, 1961.

Sprague, William B. The Life of Jedidiah Morse, D.D. New York: Anson D. F. Randolph, 1874.

Staiti, Paul J. Samuel F. B. Morse. Cambridge: Cambridge Univ. Press, 1989.

Stannard, David E. The Puritan Way of Death: A Study of Religion, Culture, and Social Change. New York: Oxford Univ. Press, 1977. 


\section{BIBLIOGRAPHY}

Stauffer, Vernon. New England and the Bavarian Illuminati. New York: Columbia Univ. Press, 1918.

Stout, Harry S. The New England Soul: Preaching and Religious Culture in Colonial New England. New York: Oxford Univ. Press, 1986.

Watts, Steven. The Republic Reborn: War and the Making of Liberal America, 1790-1820. Baltimore: Johns Hopkins Univ. Press, 1987.

Wilbur, Earl Morse. A History of Unitarianism in Transylvania, England and America. Cambridge: Harvard Univ. Press, 1952.

Windsor, Justin, ed. The Memorial History of Boston. Boston: James R. Osgood, 1883.

Wood, Gordon, ed. The Rising Glory of America, 1760-1820. New York: Braziller, 1971.

Woods, Leonard. History of Andover Theological Seminary. Boston: J. R. Osgood, 1885.

Wright, Conrad. The Beginnings of Unitarianism in America. Boston: Beacon Press, 1955. , ed. American Unitarianism, 1805-1865. Boston: Massachusetts Historical Society and Northeastern Univ. Press, 1989.

Zuckerman, Michael. Peaceable Kingdoms: The New England Towns in the Eighteenth Century. New York: Knopf, 1970.

\section{Articles}

Appleby, Joyce. "Republicanism in Old and New Contexts." WMQ, 3d ser., 43 (1986): 20-34.

Banner, Lois W. "Religious Benevolence as Social Control: A Critique of an Interpretation." Journal of American History 60 (June 1973): 23-41.

Banning, Lance. "Jeffersonian Ideology Revised: Liberal and Classical Ideas in the New American Republic." WMQ, 3d ser., 43 (1986): 3-19.

Berthoff, Rowland. "Independence and Attachment, Virtue and Interest: From Republican Citizen to Free Enterpriser, 1787-1837." In Uprooted Americans: Essays to Honor Oscar Handlin, ed. Richard L. Bushman, Neil Harris, David Rothman, Barbara M. Solomon, and Stephan Thernstrom. Boston: 1979.

Breitenbach, William. "The Consistent Calvinism of the New Divinity Movement." William and Mary Quarterly, 3d ser., 41 (1984): 241-64.

Brown, Ralph H. "The American Geographies of Jedidiah Morse." Annals of the Association of American Geographers 31 (Sept. 1941): 145-213.

Butler, Jon. "Enthusiasm Described and Decried: The Great Awakening as Interpretative Fiction." Journal of American History (Sept. 1982): 305-25.

Daniels, Bruce C. "Economic Development in Colonial and Revolutionary Connecticut: An Overview." WMQ 37 (1988): 429-50.

Giltner, John H. "The Fragmentation of New England Congregationalism and the Founding of Andover Seminar." Journal of Religious Thought 20 (1963-64): 27-42.

Jaffee, David. "The Village Enlightenment in New England, 1760-1820." WMQ 47 (July 1990): 327-46.

Kramnick, Issac. "Republican Revisionism Revisited." AHR 87 (June 1982): 629-64.

Lee, Robert Edson. "Timothy Dwight and the Boston Palladium." New England Quarterly 35 (1962): 229-46. 


\section{The Life of Jedidiah Morse \\ 172}

Lewis, W. David. "The Reformer as Conservative: Protestant Counter-Subversion in the Early Republic." In The Development of an American Culture, ed. Stanley Coben and Lorman Ratner. Englewood Cliffs, N.J.: Prentice-Hall, 1970.

Matthews, Donald G. "The Second Great Awakening as an Organizing Process, 1780 1830: An Hypothesis." American Quarterly 21 (Spring 1969): 23-44.

Nash, Gary B. "The American Clergy and the French Revolution." William and Mary Quarterly, 3d ser., 22 (1965): 392-412.

Shalhope, Robert. "Republicanism and Early American History." WMQ, 3d ser., 39 (1982): 334-56.

Shiels, Richard P. "The Second Great Awakening in Connecticut: Critique of the Traditional Interpretation." Church History 49 (1980): 401-15.

Vickers, Daniel. "Competency and Competition: Economic Culture in Early America." WMQ 47 (Jan. 1990): 4-29.

Wallace, Anthony F. C. "Identity Processes in Personality." In Cognition, Personality and Clinical Psychology, ed. Richard Jessor and Seymour Fishbach. San Francisco: Jossey-Bass, 1967.

Wallace, Anthony F. C., and Raymond Fogelson. "The Identity Struggle." In Intensive Family Therapy, ed. Ivan Baszoumenyi-Nagy and James Franco. New York: Harper and Row, 1965.

Wood, Gordon. "Conspiracy and Paranoid Style: Causality and Deceit in the Eighteenth Century." William and Mary Quarterly, 3d ser., 39 (1982): 401-41.

- "The Democratization of Mind in the American Revolution." In The Moral Foundations of the American Republic, ed. Robert H. Horowitz. 2d ed. Charlottesville: Univ. of Virginia Press, 1979.

Wright, Conrad. "The Controversial Career of Jedidiah Morse." Harvard Library Bulletin 31, no. 1 (1983): 163-80.

- "The Election of Henry Ware: Two Contemporary Accounts." Harvard Library Bulletin 17 (July 1969): 245-78.

Zuckerman, Michael. "The Fabrication of Identity in Early America." WMQ 34, 3d ser. (1977): 183-213. 


\section{Index}

Adams, Hannah, 103-4, 106-12

Adams, John, 63, 69, 75, 77, 82, 138

American Geography, The, 26, 35, 38, 40, 43-45, 47-49, 55, 58, 62, 71; on

New England, 38, 42-43, 45-47,

51 ; on the South, $35,41-43,45,47$,

62 ; on slavery, 41-43, 45-47, 6062,83

American Universal Geography, The, 58, 60, 100, 107, 113

Andover Seminary, 90-93, 110, 114, 122, 124; see also Morse, Jedidiah

Baptists, 3-4, 60, 78, 98

Belknap, Jeremy, 36, 48, 134

Bentley, William, 57, 77-78

Boston, Mass., 55-57, 59-60, 74, 81, 97-98, 103, 105-7, 112

Breese, Elizabeth, 35, 53, 99, 116, 120 26, 130-31, 133, 139-40, 145; see also Morse, Jedidiah

Calvinism, xii, $5,15,55,57,78,83$, 85, 88-92, 102, 106, 127

Cambridge platform, 1-4

capitalism, xi, xiii, 55, 72, 81, 136

Charlestown, Mass., ix, xi, xiv, 13, 3638, 51, 66-68, 70-72, 75, 94-96, 101, 108-9; see also Morse, Jedidiah

Congregationalism, xii, 4, 14, 19-22, $59-60,78,84-86,92,106$

Constitution, U.S., 35-36, 38, 47, 62$63,66,80,84$ deference, $x-x i i, 14,38,48,50-52,61$, 84, 95, 120; see also equalitarianism

Democratic-Republicans. See

Jeffersonian Republicans

Dwight, Timothy, 56, 76, 82, 123, 138

Edwards, Jonathan, 88

Elements of Geography, 58, 62-63, 100

Enlightenment, 25, 134, 137-38

equalitarianism, xi, $17,48,52,61$

Federalists, 4, 56, 60-62, 66-69, 78$79,81-83,94$

France, 38, 55, 63-66, 69, 73, 75-76, $79,81-82,138$

Geography Made Easy, 25-26, 38, 58, $60,100,107,113$

Great Awakening, 2, 15, 48; see also New Divinity

Great Britain, 16, 55, 62-64, 66

Hamilton, Alexander, 22, 61, 69, 75, $81,83,95$

Harvard College, 56-57, 84-86, 89-90, 92, 105

Hazard, Ebenezer, 35-36, 53

Higginson, Stephen, Jr., 103-5, 107, 109-10

Holmes, Abiel, 19, 26, 35, 49-50, 57, 88-89, 134

Hopkinsian, 88-92; see also Calvinism; Panoplist 
Illuminati sermons, 68-81, 88, 96-97, $112,130,138$

Jay Treaty, 66-68, 74, 78

Jefferson, Thomas, 22, 61, 69, 75, 81, 83,95

Jeffersonian Republicans, 4, 55-56, 61, $69,77,81-83$

jeremiads, xiii, $38,45,47,51,66,159 n$

Leonard, Abiel, 4-6, 9, 51

liberalism, $\mathrm{x}-\mathrm{xi}$, xiv, 55 ; see also religious liberalism

Morse, Jedidiah, as a minister in

Charlestown, ix, 21, 25-26, 35-38, 47-57, 67, 70-71, 79, 81, 86, 97103, 107, 112-18, 131-32, 143; at Yale, xiv, 11, 13-33, 40, 78; childhood, 1, 3-6, 10-12, 50-51; conspiracy theories of, $\mathrm{ix}-\mathrm{x}$, xiii-xiv, 54-55, 73, 78-79, 83-84, 86-89, 105-6, 112, 131; contributions to the Panoplist, ix, 86-90, 92; critics of, 59-60, 71-72, 77-78, 81, 1012, 104-5, 111-15, 137; family, 35, $53,99,111,114,116-30,132-33$, 138-41; financial matters of, 25-26, 48-49, 59, 66, 72-73, 107-12, 118, 128, 132, 139-40; geographies, ix, xiii, 25-26, 35-36, 38, 45, 47-48, 50-52, 57-62, 83, 100, 107, 116$17,132,136$; identity diffusion of, $x$, xii-xiv, 21, 24-29, 32-35, 47, 49$52,66,72,75-76,78-81,96-97$, $100,129,141,143$; marriage to Elizabeth Breese, 35, 52-53, 116, 120-21, 133; on Indian policy, 93, 133-38, 149; opposition to religious liberalism, ix-xii, 55-57, 59-60, 79-92, 95, 101-2, 105-7, 112; relations with father, xii-xiv, 6, 10-14, 17-18, 20-21, 24-26, 33, 49-50,
$52,97,99,108,117$; religious beliefs of, 18-24, 31-33, 54, 78-79, 83-84; sermons, xiii, 54-55, 63-66, 68,70 ; views on blacks and slavery, 94-95, 98, 135; see also American Geography; Illuminati sermons

Morse, Jedidiah, Sr., xii, 1-4, 6-13, 16, 40, 66-67, 99, 101, 117, 120, 124, 126-27, 129, 138, 143-44, 148, $154 \mathrm{n}$; see also Morse, Jedidiah

Morse, John, 2-4, 6-7

Morse, Samuel F. B., ix, 106, 110, 114$16,118-19,121-33,139-40,143-$ 49, 165n; see also Morse, Jedidiah

New Divinity, 15, 25, 91

New England Palladium, 82-83, 97, 118

New Haven, Conn., 14-16, 23, 25, 81, $128,131-32,138,156$ n

Paine, Thomas, 70, 75

Panoplist, ix, 86-90, 105, 118; see also Morse, Jedidiah

Phillips Academy, 90, 99, 122-23

Puritanism, $x-x i, 37,57,92$

Putnam, Aaron, 108-10, 128

religious liberalism, 56-57, 84-86, 89, 105-6; see also Morse, Jedidiah; Harvard College

republicanism, ix-xi, xiv, 1, 12, 29-31, 39, 46, 54-55, 61, 141

Revolutionary War, ix-xii, 2, 4-6, 13, $15-16,21,30,37-38,46-48,51$, $55,62-63,156 \mathrm{n}$

Robison, John, 68-69, 72-73, 76-78, 112; see also Illuminati sermons

Saybrook platf orm, 2-3, 5

Shay's Rebellion, 35, 62

Stiles, Abel, 2-3, 6-7

Stiles, Ezra, 15-17, 19-22, 25-26, 29, $156 n$ 


\section{INDEX}

Tappan, David, 57, 84, 89

Unitarianism, 55-56, 85, 87, 92, 98, $103,106-7,112,130,138$

Washington, George, 35, 60-63, 6566, 69

Whiskey Rebellion, 65-66

Whitefield, George, 37

Woods, Leonard, 90-91, 114-15
Woodstock, Conn., xi, xiv, 1-6, 11-14, 20, 23-24, 48, 50-51, 62, 99, 108, 117-18; see also Morse, Jedidiah

Woolcott, Oliver, Jr., 61-62, 67-68, 79, 81-82

Yale College, 14-19, 22, 25, 56, 82, 93, 122-28, 146, 149; see also Morse, Jedidiah 

projected a public persona-that of the devoted cleric-to compensate for the "hidden" identity he feared-that of the capitalist individualist. In this light, Morse's penchant for conspiracy theories-directed against such groups as the French Illuminati and the Unitarians-can be seen as "ritual moments" in which he strove to prove himself loyal to his Christian concept of virtue.

The Author: Richard J. Moss is professor of history at Colby College and the author of Noab Webster.

Jacket design: Kay Jursik.

Jacket illustration: Samuel F. B. Morse, The Reverend Jedidiah Morse, 1809 . Oil on panel $28-3 / 4$ by $22-7 / 8$ inches. Courtesy of Yale University Art Gallery (gift of Helen E. Carpenter). 


\section{Also of Interest}

\section{The Angelical Conjunction}

THE PREACHER-PHYSICIANS OF

COLONIAL NEW ENGLAND

Patricia Ann Watson

200 pages

\section{The First of Men}

A LIFE OF GEORGE WASHINGTON

John E. Ferling

704 pages, illustrations

\section{John Adams}

A LIFE

John E. Ferling

552 pages, illustrations

\section{q}

The University of Tennessee Press

Knoxville 37996-0325

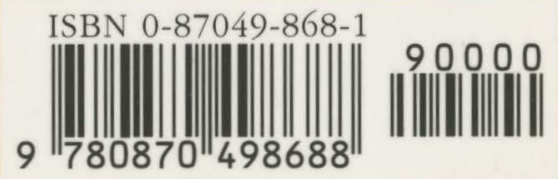

